Florida International University FIU Digital Commons

7-16-2012

\title{
Geochemical Determination of the Fate and Transport of Injected Fresh Wastewater to a Deep Saline Aquifer
}

Virginia M. Walsh

Florida International University,walshv@miamidade.gov

DOI: $10.25148 /$ etd.FI12080616

Follow this and additional works at: https://digitalcommons.fiu.edu/etd

\section{Recommended Citation}

Walsh, Virginia M., "Geochemical Determination of the Fate and Transport of Injected Fresh Wastewater to a Deep Saline Aquifer" (2012). FIU Electronic Theses and Dissertations. 692.

https://digitalcommons.fiu.edu/etd/692 


\title{
FLORIDA INTERNATIONAL UNIVERSITY
}

Miami, Florida

\section{GEOCHEMICAL DETERMINATION OF THE FATE AND TRANSPORT OF INJECTED FRESH WASTEWATER TO A DEEP SALINE AQUIFER}

A dissertation submitted in partial fulfillment of

$$
\text { the requirements for the degree of }
$$

DOCTOR OF PHILOSOPHY

\author{
in \\ GEOSCIENCES \\ by \\ Virginia Mary Walsh
}


To: $\quad$ Dean Kenneth G. Furton

College of Arts and Sciences

This dissertation, written by Virginia Mary Walsh, and entitled Geochemical Determination of the Fate and Transport of Injected Fresh Wastewater to a Deep Saline Aquifer, having been approved in respect to style and intellectual content, is referred to you for judgment.

We have read this dissertation and recommend that it be approved.

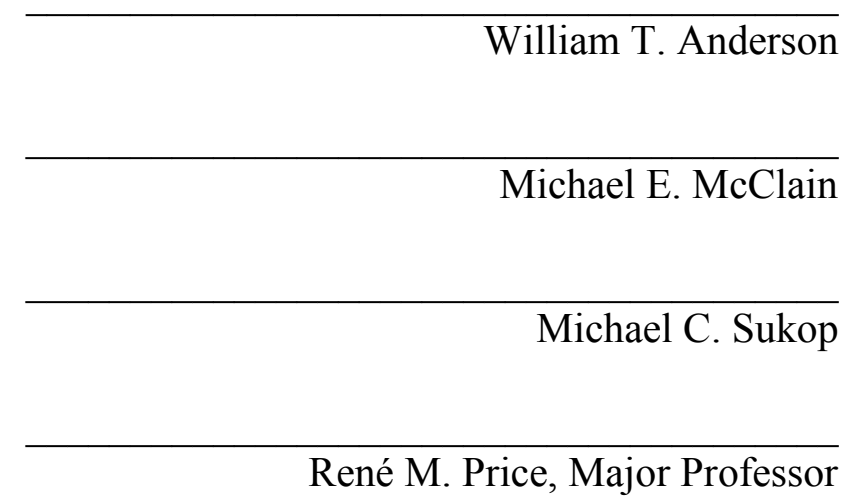

Date of Defense: July 16, 2012

The dissertation of Virginia Mary Walsh is approved.

Dean Kenneth G. Furton College of Arts and Sciences

Dean Lakshmi N. Reddi

University Graduate School

Florida International University, 2012 
(C) Copyright 2012 by Virginia Mary Walsh

All rights reserved. 


\section{DEDICATION}

This work is dedicated to the very loving memory of David R. Walsh and Katherine Walsh Maleck. 


\section{ACKNOWLEDGMENTS}

I thank my major advisor, Dr. René M. Price, and committee members, Dr. William T. Anderson, Dr. Michael E. McClain, and Dr. Michael C. Sukop, for their support, guidance and wisdom during the course of this dissertation. I would especially like to express my deepest gratitude to Dr. Price for her patience with me. She truly inspired in me a passion for my research, and the resolve to complete this dissertation.

I thank the many people who made the collection and analysis of these data possible, especially Sonia Villamil, Clive Powell, Steven Kronheim, Noel Grant, Silvia Fields, Gerald Caracappa, and Andy Toledo of Miami Dade Water and Sewer Department (MDWASD). I would also like to thank Terry Petrovsky and Adam Foster of the U.S. Geological Survey for their invaluable technical expertise and assistance in the field. I thank Adam Foster, Drs. Andrew Hunt, Christian Langevin, Alyssa Dausman, and Jeffery King of the U.S. Geological Survey for their insightful comments during this research.

I owe deep gratitude to MDWASD for funding this project, and especially to William Pitt and Bertha Goldenberg of MDWASD for their cooperation. I thank my colleagues at MDWASD, Sonia Villamil, Clint Oakley and Idia MacFarlane, for their support over the years, and especially for allowing me the time to complete this dissertation. I thank all the laboratory chemists, technicians, and field personnel at the South and North District Wastewater Treatment Plants for their assistance with sampling, laboratory analyses, and equipment.

Finally, I would like to thank my friends, sisters and brothers, and my many nieces and nephews the world over for their endless understanding and inspiration 
through these years. I especially thank my mother, Rosemary Walsh, for her love and support over the years, and her insistence that I finish this dissertation. She provided me much motivation and encouragement during difficult times. 


\title{
ABSTRACT OF THE DISSERTATION \\ GEOCHEMICAL DETERMINATION OF THE FATE AND TRANSPORT OF INJECTED FRESH WASTEWATER TO A DEEP SALINE AQUIFER
}

\author{
by \\ Virginia Mary Walsh \\ Florida International University, 2012 \\ Miami, Florida \\ Professor René M. Price, Major Professor
}

Deep well injection into non-potable saline aquifers of treated domestic wastewater has been used in Florida for decades as a safe and effective alternative to ocean outfall disposal. The objectives of this study were to determine the fate and transport of injected wastewater at two deep well injection sites in Miami Dade County, Florida, USA.

Detection of ammonium in the Middle Confining units of the Floridan aquifer above the injection zone at both sites has been interpreted as evidence of upward migration of injected wastewater, posing a risk to underground sources of drinking water. Historical water quality data, including ammonia, chloride, temperature, and $\mathrm{pH}$ from existing monitoring wells at both sites from 1983 to 2008, major ions collected monthly from 2006 and 2008, and a synoptic sampling event for stable isotopes, tritium, and dissolved gases in 2008, were used to determine the source of ammonium in groundwater and possible migration pathways. Geochemical modeling was used to determine possible effects of injected wastewater on native water and aquifer matrix geochemistry. 
Injected wastewater was determined to be the source of elevated ammonium concentrations above ambient water levels, based on the results of major ion concentrations, tritium, dissolved noble gases and ${ }^{15} \mathrm{~N}$ isotopes analyses. Various possible fluid migration pathways were identified at the sites. Data for the south site suggest buoyancy-driven vertical pathways to overlying aquifers bypassing the confining units, with little mixing of injected wastewater with native water as it migrated upward. Once it is introduced into an aquifer, the injectate appeared to migrate advectively with the regional groundwater flow. Geochemical modeling indicated that $\mathrm{CO}_{2}$-enriched injected wastewater allowed for carbonate dissolution along the vertical pathways, enhancing permeability along these flowpaths. At the north site, diffusive upward flow through the confining units or offsite vertical pathways were determined to be possible, however no evidence was detected for any on-site confining unit bypass pathway. No evidence was observed at either site of injected wastewater migration to the Upper Floridan aquifer, which is used as a municipal water supply and for aquifer storage and recovery. 


\section{TABLE OF CONTENTS}

\section{CHAPTER}

\section{PAGE}

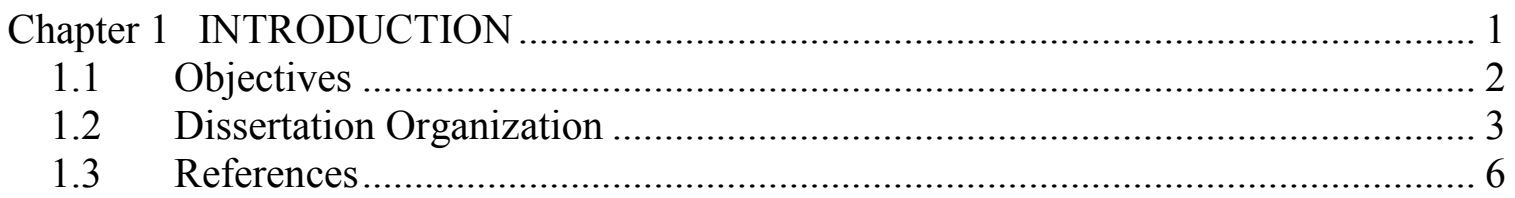

Chapter 2 DETERMINATION OF VERTICAL AND HORIZONTAL PATHWAYS

OF INJECTED FRESH WASTEWATER INTO A DEEP SALINE AQUIFER

(FLORIDA, USA) USING NATURAL CHEMICAL TRACERS …………………….... 7

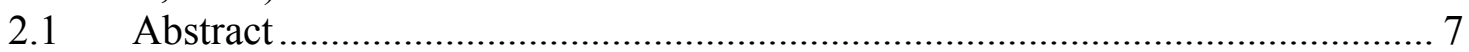

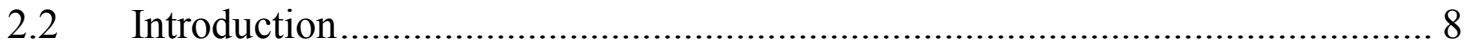

2.3 Geologic and hydrogeologic framework ……….......................................... 11

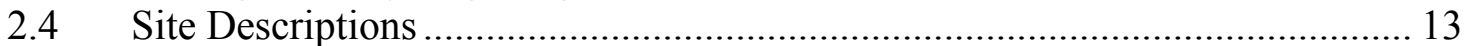

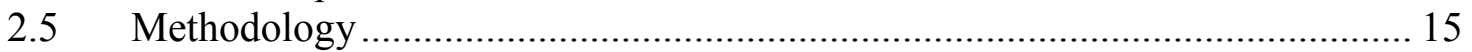

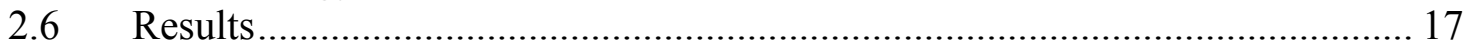

2.6.1 Historical Time Series Results - SDWWTP …………………………..... 17

2.6.2 Historical Time Series Results - NDWWTP ............................................. 19

2.6.3 Major Ion Data Collection Results …………....................................... 20

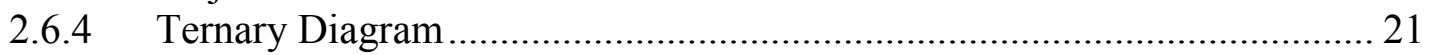

2.6.5 Mixing End-member Models ............................................................... 22

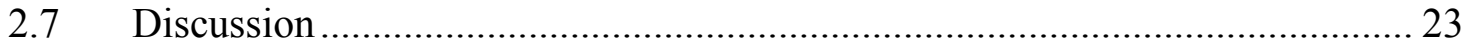

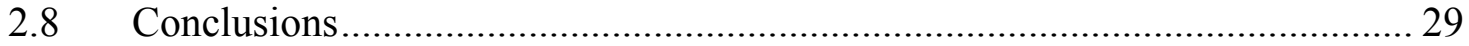

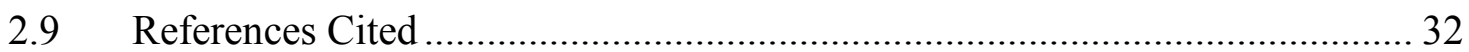

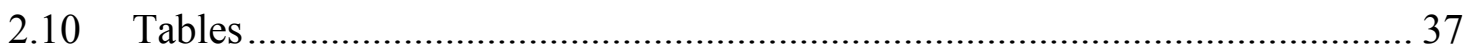

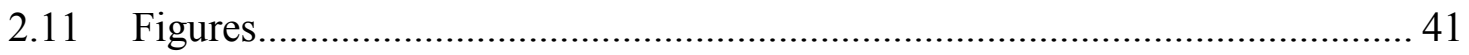

Chapter 3 THE FATE AND TRANSPORT OF AMMONIUM FROM FRESH WASTEWATER INJECTED INTO A DEEP SALINE AQUIFER AS DETERMINED FROM NATURAL ISOTOPES AND DISSOLVED GASES ………………................ 51

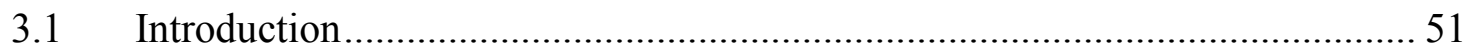

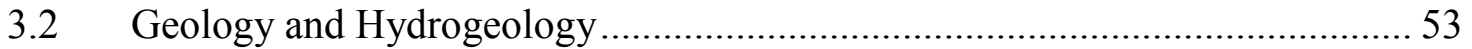

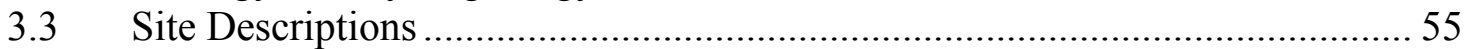

3.4 Background on Isotopes and Dissolved Gases …………………..................... 56

3.4.1 Nitrogen Stable Isotopes ........................................................................... 56

3.4.2 Background on Stable Isotopes of Oxygen and Hydrogen .......................... 57

3.4.3 Background - Dissolved Gases …………………..................................... 59

3.4.4 Background - Relative Age Dating Tritium $/{ }^{3}$ Helium ................................... 63

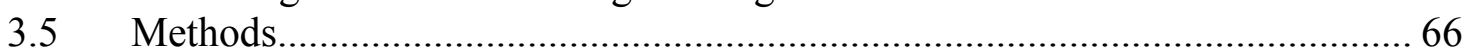

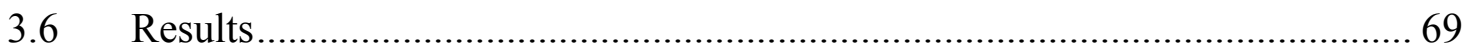

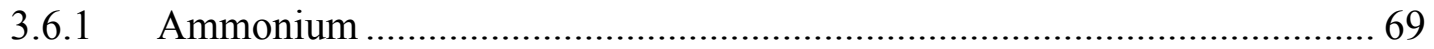

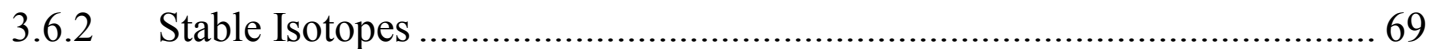

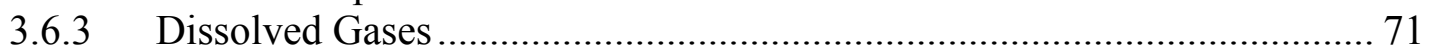

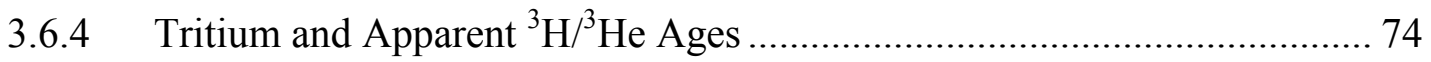




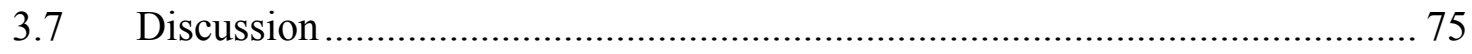

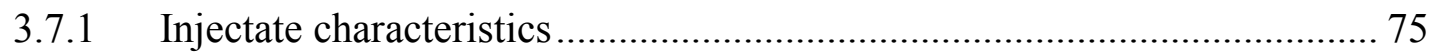

3.7.2 Ambient Water Quality and Recharge source ......................................... 75

3.7.3 Evidence of injectate migration ............................................................... 79

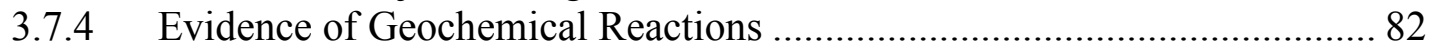

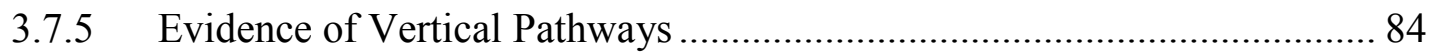

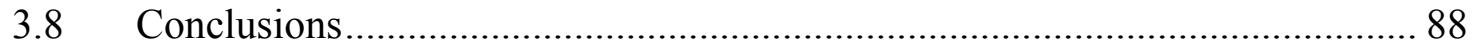

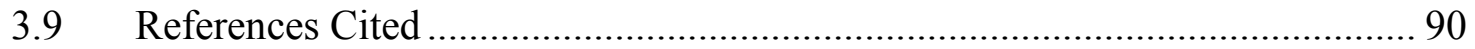

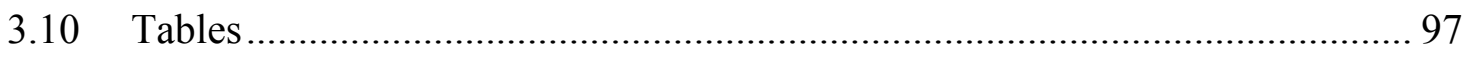

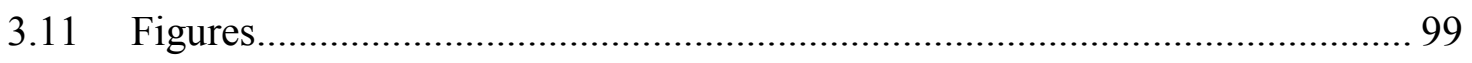

Chapter 4 EFFECTS ON CARBONATE EQUILIBRIUM FROM MIXING FRESH WASTWATER IN A DEEP SALINE AQUIFER, SOUTH FLORIDA, U.S.A............. 112

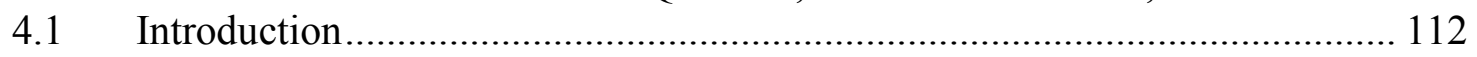

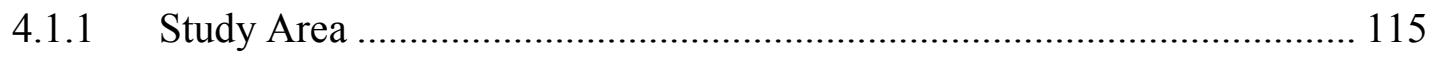

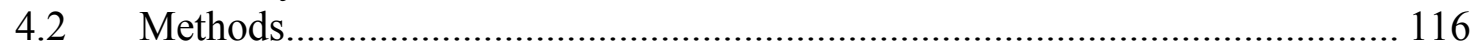

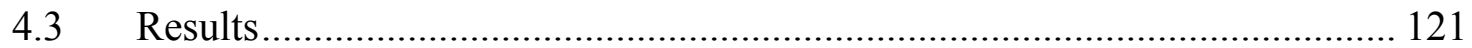

4.3.1 Binary mixing model results............................................................ 121

4.3.2 Carbonate mineral saturation indices results ......................................... 122

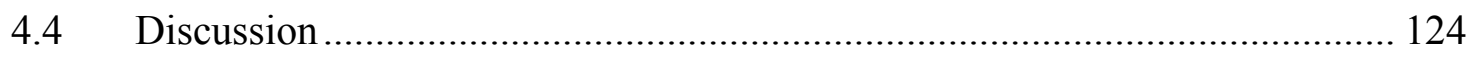

4.4.1 Binary mixing models results ........................................................... 124

4.4.2 $\quad \mathrm{P}_{\mathrm{CO} 2}$ and carbonate equilibrium............................................................ 125

4.4.3 Injectate excess $\mathrm{CO}_{2}$ and methanogenesis in carbonate equilibrium........ 126

4.4.4 Evidence of Confinement Bypass Pathways.............................................. 128

4.4.5 Porosity enhancement and confinement bypass pathways ........................ 130

4.4.6 North District Results ...................................................................... 132

4.4.7 Suggested model for vertical migration of injectate ................................ 132

4.4.8 Implications for Floridan aquifer storage and recovery ........................... 133

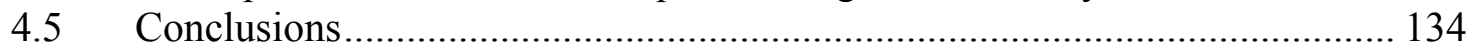

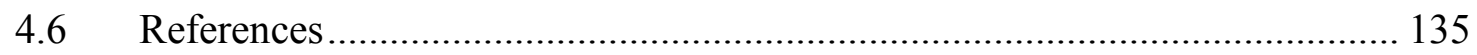

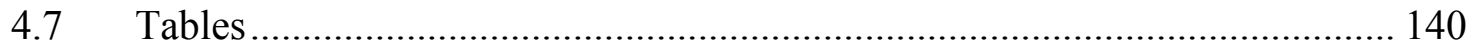

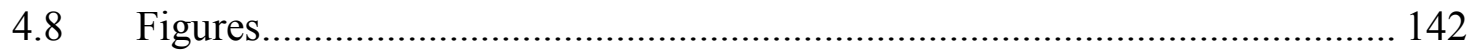

Chapter 5 SUMMARY AND CONCLUSIONS ………………………………….... 157

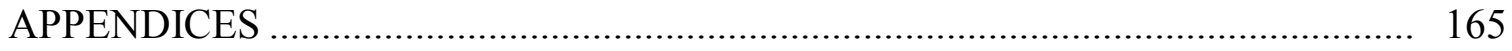

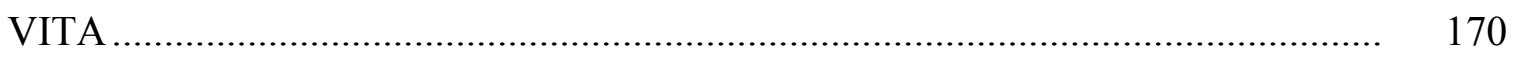




\section{LIST OF TABLES}

TABLE

PAGE

Table 2.1 Mean values for historical time series: SDWWTP. mbls meters below

land surface

Table 2.2 Mean values for historical time series: NDWWTP. mbls below land surface

Table 2.3 Mean field parameters and ion concentrations during the 2006-2007 sampling completed as part of this study. mbls

Table 2.4 Historical ambient Floridan Aquifer water quality data

Table 3.1 Ammonium, stable isotope, dissolved gases and ${ }^{3} \mathrm{H} /{ }^{3} \mathrm{He}$ data. monitoring well open interval depth in meters below land surface

Table 3.2 Dissolved noble gas concentrations.....

Table 4.1 December 2007 water quality sampling results used in this study. * dissolved gas samples collected February 2008.

Table 4.2 Log $\mathrm{P}_{\mathrm{CO} 2}$ and Saturation indices of calcite, dolomite, aragonite and gypsum. Well with elevated $\mathrm{NH}_{4}{ }^{+}$concentrations are italicized. $\mathrm{P}_{\mathrm{CO} 2}$ are calculated from observed $\mathrm{CO}_{2}$ concentrations. 


\section{LIST OF FIGURES}

FIGURE

PAGE

Figure 2.1 Location of the NDWWTP and the SDWWTP study sites.

Figure 2.2 Geologic and hydrogeologic framework of NDWWTP and the SDWWTP, modified from Reese and Richardson, 2008. Well diagram on the right shows the number of wells open to the indicated hydrogeologic unit used for this study.

Figure 2.3 Well locations at the SDWWTP.....

Figure 2.4 Well locations at the NDWWTP....

Figure 2.5 Time series $\mathrm{NH}_{3}$ data from the injectate (black circle), BZ-4 (green triangle) and well 6U (red circle) at the SDWWTP site. The apparent seasonal variation observed in the injectate is a result of increased flows during the wet season and storm events. The increasing trends with time correlate to increased injection over time due to growth in population in Miami-Dade County.

Figure 2.6 Graph a shows the $\mathrm{NH}_{3}$ data time series for the wells in the APPZ interval at the NDWWTP. The dashed lines indicate the purging time from 2003 through 2004. $\mathrm{NH}_{3}$ concentrations are observed to increase in well N-1L similar to contaminant breakthrough contaminant breakthrough curves. Well N-1L was the closest well to the uncased injection well when injectate backflowed into the APPZ. $\mathrm{NH}_{3}$ concentrations for wells N-2L, N-3L, and N-4L appear to be similar and show a similar increase after 1999. Variability is seen in the data after 2003. Graph b shows $\mathrm{Cl}^{-}$concentrations in well N-1L clustered at approximately $300 \mathrm{mM}$, and an abrupt decrease to less than $300 \mathrm{mM}$ is seen. $\mathrm{Cl}^{-}$concentrations in wells $\mathrm{N}-2 \mathrm{~L}, \mathrm{~N}-3 \mathrm{~L}$, and $\mathrm{N}-4 \mathrm{~L}$ are very similar, and show a decrease in concentrations after 1999 until 2000, when concentrations appear to stabilize. $\mathrm{Cl}^{-}$concentrations start to increase slightly and become variable after 2003. All four wells show similar concentrations of both $\mathrm{NH}_{3}$ and $\mathrm{Cl}^{--}$after 2004 .

Figure 2.7 Ternary diagrams for the NDWWTP and the SDWWTP. $\mathrm{NH}_{4}^{+}, \mathrm{Cl}^{-}$, and $\mathrm{Br}^{-}$data collected from 2006 - 2007 were normalized to $100 \%$. Seawater and freshwater values (Hem, 1985) were plotted. Ambient water was grouped at the SDWWTP for the MC2 and UFA intervals. Ambient MC2 data plot directly with seawater. UFA ambient plots towards freshwater, reflecting the fresher water quality in the UFA. The injectate data plot at the $\mathrm{NH}_{4}^{+}$end point, indicating the freshwater quality but high $\mathrm{NH}_{4}{ }^{+}$concentration of the injectate. Well data from the 
APPZ and MC2 intervals that have $\mathrm{NH}_{4}{ }^{+}$concentrations above ambient levels plot in a line towards the injectate end point, with data from wells $6 \mathrm{U}$ and $12 \mathrm{~L}$ plotting very close the $\mathrm{NH}_{4}{ }^{+}$end point. Data from the SDWWTP plot into distinct groups based on depth in the aquifer, but no line towards the injectate end point is seen.

Figure 2.8 Graphs on the left are $\mathrm{NH}_{3} / \mathrm{Cl}^{-}$mixing end member models for the APPZ and MC2 intervals at the SDWWTP. $6 \mathrm{U}, 12 \mathrm{~L}$ and $10 \mathrm{~L}$ are well identification codes. Arrows indicate increase in time. Hatched red rectangle is injected freshwater end member, indicating the seasonal range in concentrations. Cyan square is the APPZ brackish water ambient water end member; blue circle is the MC2 saline water end member. Graphs on the right are $\mathrm{NH}_{3}$ concentrations over time. Solid black lines are concentrations from each well site; red line is injected freshwater concentrations. For wells $6 \mathrm{U}$ and $12 \mathrm{~L}$ the data plot towards the injectate end member. Little influence is seen in well $6 \mathrm{U}$ from the saline MC2 end member. Well 10L shows a different evolution of water quality, with data plotting at the saline MC2 end member and slowly plotting towards the lower end of the injectate end member.

Figure 2.9 Graph a is the $\mathrm{NH}_{3} / \mathrm{Cl}^{-}$mixing end member model for the APPZ at the NDWWTP for pre-purge data (prior to 2003) for well N-2L. Arrows indicate increase in time. Hatched red rectangle is injected freshwater end member, indicating the seasonal range in concentrations. Cyan square is the UFA brackish water ambient water end member; blue circle is the APPZ saline water end member. The data plot in separate groupings, with the earliest time series plotting around the APPZ saline end member. The second data cluster plot towards the injectate end member, but no evolution towards the injectate end member is seen as was seen for wells $6 \mathrm{U}$ and $12 \mathrm{~L}$ at the SDWWTP. Graph $\mathbf{b}$ is the postpurge data plotted for well N-1L. Data plot with time back towards the APPZ saline end member.

Figure 2.10 Location of injectate plumes and their depth interval at the SDWWTP. The source of the plume centered on the BZ well clusters (plume 1) was plugged in 1995. The plumes 2, 3, and 4 are the result of continuing rapid vertical pathways up from the Boulder Zone. The extent of the plumes off site is not known, as indicated by the question marks, however, based on data collected from the site, approximate extent of the plumes on the site can be inferred. The plume in the MC2 is limited to the southeast of the site. The plume located in the northwest of the site is located in the APPZ, and appears to have bypassed the $\mathrm{MC} 2$. The plume from the $\mathrm{BZ}$ well cluster appears to be limited to the east of the site. It is unknown the extent of the plume at $14 \mathrm{U}$ on site, as there are no wells that monitor the same aquifer interval in the vicinity of $14 \mathrm{U}$. 
Figure 3.1 Location of the north, south, and the ASR study sites.

Figure 3.2 Geologic Cross section.

Figure 3.3 Well location at the south site. Each well consists of an upper zone (U) and a lower (L) monitoring zone. Each well is in close proximity to an injection well (which are not shown to retain clarity in figure).

Figure 3.4 Well location at the north site. Each well consists of an upper zone (U) and a lower (L) monitoring zone. Each well is in close proximity to an injection well (which are not shown to retain clarity in figure).

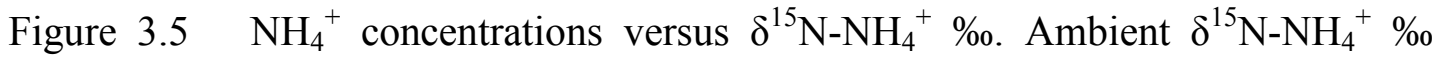
values decrease with depth in the aquifer, suggesting different sources of $\mathrm{NH}_{4}^{+}$in different zones in FAS. Wells with elevated $\mathrm{NH}_{4}^{+}$ concentrations at south and north sites had increasing $\delta^{15} \mathrm{~N}_{-} \mathrm{NH}_{4}{ }^{+} \%$ value with decreasing $\mathrm{NH}_{4}{ }^{+}$concentrations.

Figure $3.6 \quad \delta^{2} \mathrm{H} \%$ vs $\delta^{18} \mathrm{O} \%$ values. Ambient values cluster according to depth in the aquifer, suggesting little hydrologic connection between monitored zones. Ambient deeper zones plot heavier than seawater; ambient upper zones plot off to the right indicating evaporative meteoric sources. $\mathrm{MC1}$ zones with elevated $\mathrm{NH}_{4}{ }^{+}$concentrations at the south site lie along mixing line to injectate values, and do not show any mixing from underlying MC2 zone.

Figure 3.7 Dissolved gas vs. $\mathrm{NH}_{4}{ }^{+}$concentrations. $\mathrm{N}_{2}$ and argon concentrations from the zones with elevated $\mathrm{NH}_{4}{ }^{+}$concentrations reflect the cryogenic treatment process in the injectate, with well $6 \mathrm{U}$ having very similar concentrations of those gases to the injectate. $\mathrm{CO}_{2}$ concentrations in well $6 \mathrm{U}$ show a much quicker decrease than either $\mathrm{N}_{2}$ or argon, and along with the appearance of $\mathrm{CH}_{4}$ in wells with elevated $\mathrm{NH}_{4}^{+}$concentrations, would suggest methanogenic processes. Dotted line on $\mathrm{N}_{2}$ and argon binary plots are mixing line between injectate and ambient concentrations; dashed line is mixing line between well $6 \mathrm{U}$ and ambient concentrations.

Figure 3.8 Dissolved gas vs. $\mathrm{NH}_{4}^{+}$concentrations at the north site. Although the impact of the cryogenic process is evident in lower MC1 zone, the dissolved gas concentrations lie closer to ambient concentrations. $\mathrm{N}_{2}$ concentrations for lower $\mathrm{MC} 1$ are similar to the $\mathrm{N}_{2}$ concentrations at the ambient MC2 zone at the south site.

Figure 3.9 Dissolved noble gases vs. $\mathrm{NH}_{4}{ }^{+}$concentrations. Dissolved gas concentrations from zones with elevated $\mathrm{NH}_{4}{ }^{+}$concentrations reflect the cryogenic treatment process in the injectate, with well $6 \mathrm{U}$ having very 
similar concentrations of those gases to the injectate. Neon, argon and krypton concentrations for well $6 \mathrm{U}$ are very similar to the injectate, however, $\mathrm{NH}_{4}{ }^{+}$concentrations are lower than injectate. Data from the north site (yellow triangles) are plotted to show the little variance between samples.

Figure 3.10 Neon and xenon concentrations. ASW: air saturated water; ASSW: air saturated sea water. MC2 ambient plot to the right of ASSW at $8^{\circ} \mathrm{C}$, which would be consistent with Holocene-age recharge from the Florida Straits. Impacted $\mathrm{MC1}$ at the south site shows mixing trend from well 6U to ASW equilibrium line. $\mathrm{MC1}$ from the north site shows little variance between concentrations, and do not show a gradual mixing as seen in $\mathrm{MC} 1$ south data.

Figure $3.11{ }^{3} \mathrm{H} /{ }^{3} \mathrm{He}$ age vs. $\mathrm{NH}_{4}{ }^{+}$concentrations. Samples grouped into "new" (recent recharge with injectate), "mixed" (mixed between new and old water), and "old" (tritium dead water, recharge prior to initiation of plant operations). Well BZL overlapped between "mixed: and "old", reflecting the injectate plume at BZL a result of an open connection to the $\mathrm{BZ}$ present at the commencement of site operations in the early 1980 's.

Figure $3.12 \delta^{18} \mathrm{O} \%$ values vs. $\mathrm{NH}_{4}{ }^{+}$concentrations. Zones with elevated $\mathrm{NH}_{4}{ }^{+}$concentration mixing trends trace back to injectate; $\mathrm{MCl}$ with $\mathrm{NH}_{4}{ }^{+}$concentrations shows no evidence of $\mathrm{MC} 2$ mixing.

Figure 4.1 Location of the South District Wastewater Treatment Plant and North District Wastewater Treatment plant in Miami-Dade County Florida, USA. Inset locates the two sites in the state of Florida

Figure 4.2 Well locations at the SDWWTP. Wells 1U, 2U, 3U and BZU monitor the UFA. Wells $5 \mathrm{U}, 6 \mathrm{U}, 7 \mathrm{U}, 8 \mathrm{U}, 9 \mathrm{U}, 10 \mathrm{U}, 11 \mathrm{U}, 12 \mathrm{U}, 13 \mathrm{U}, 14 \mathrm{U}, 15 \mathrm{U}$ and $16 \mathrm{U}$ monitor the MCA; wells $2 \mathrm{~L}$ and BZ2 monitor the APPZ; wells labeled 1L, 31, 4L, 5L, 6L, 7L, 8L, 8L, 9L, 10L, 11L, 12L, 13L, 15L and $16 \mathrm{~L}$ monitor the saline MC2 zone. Wells circled in red were used in this study.

Figure 4.3 Well Well locations at the NDWWTP. Wells labeled with a "U" monitor the lower UFA and Upper MC1 zones in the Floridan aquifer system. The wells labeled with a "L" monitor the lower MC1 and APPZ.

Figure 4.4 Geologic and hydrogeologic framework of the north and south sites, modified from Reese and Richardson, 2008.

Figure 4.5 Binary mixing model results for the $\mathrm{MC} 1$ at the SD for the December 2006 (graph a) and December 2007 (graph b) sampling events. Black 
circles are the $\mathrm{Cl}^{-} \mathrm{BMM}$, green triangles are the $\mathrm{Br}^{-} \mathrm{BMM}$, red circles are the $\mathrm{NH}_{4}{ }^{+} \mathrm{BMM}$, and the yellow triangles are the Argon BMM. Wells have similar $\mathrm{Cl}^{-}, \mathrm{Br}^{-}$and $\mathrm{NH}_{4}{ }^{+}$BMM results, with the exception of well $16 \mathrm{U}$. Argon appears to overpredict the $\mathrm{f}_{\text {inj. }}$.

Figure 4.6 BMM results for the SD MC2 (graph a) and the ND APPZ zones (graph b). Argon sample for the endmember of the MC2 zone was lost, and therefore a Argon BMM could not be completed. Wells at the SD MC2 have similar $\mathrm{Cl}^{-}$and $\mathrm{Br}^{-} \mathrm{BMM}$ results, while $\mathrm{NH}_{4}{ }^{+} \mathrm{BMM}$ may slightly underpredict $\mathrm{f}_{\text {inj. }}$. The $\mathrm{NH}_{4}{ }^{+} \mathrm{BMM}$ appears to overpredict the $\mathrm{f}_{\text {inj }}$ for the ND wells.

Figure 4.7 Saturation indices (SI) versus sample depth in aquifer (graph a), and versus sample $\mathrm{NH}_{4}^{+}$concentrations (graph b). Saturation state points are from the SD, except those noted for the ND in the legend. Saturation states did not appear to be related to depth in the aquifer, but rather appear to be related to the $\mathrm{NH}_{4}{ }^{+}$concentration for the $\mathrm{MC} 1$ and $\mathrm{MC} 2$ at the SD.

Figure 4.8 PHREEQC calculated SI for calcite as percentage of injectate (curve), and calculated SI from wells in the MC1 (graph a) and the MC2 (graph b) at the SD. The data points indicated as well $6 \mathrm{U}_{\text {inj PCO2 }}$ and well $12 \mathrm{~L}_{\text {inj } \mathrm{PCO} 2}$ is the saturation index calculated for those wells using the $\mathrm{P}_{\mathrm{CO} 2}$ for injectate.

Figure 4.9 PHREEQC calculated SI for dolomite (graph a) and aragonite (graph b) as percentage of injectate (curve), and calculated SI from wells in the $\mathrm{MC} 1$ at the SD.

Figure 4.10 PHREEQC calculated $\mathrm{P}_{\mathrm{CO} 2}$ as percentage of injectate curve, with observed $\mathrm{P}_{\mathrm{CO} 2}$ plotted for wells in the $\mathrm{MC} 1$ at the $\mathrm{SD}$.

Figure $4.11 \mathrm{CO}_{2}$ versus methane concentrations at the SD. Injectate is highly enriched in $\mathrm{CO}_{2}$ and depleted in $\mathrm{CH}_{4}$ as a result of the cryogenic treatment and methane co-generation processes at the SD. Wells with elevated $\mathrm{NH}_{4}{ }^{+}$concentrations (illustrated here by well 6U) contain elevated $\mathrm{CH}_{4}$ concentrations. Wells with decreasing $\mathrm{NH}_{4}^{+}$ concentrations become depleted in $\mathrm{CH}_{4}$ as excess $\mathrm{CO}_{2}$ is consumed as a result of methanogenesis.

Figure 4.12 Comparison of observed $\mathrm{Ca}^{2+}$ and $\mathrm{Na}^{+}$concentrations (red circles) in the $\mathrm{MC1}$ to a two endmember solution mixture, (with well 9U in the MC1 and injectate the two endmembers), and to a three endmember solution mixture (with well $9 \mathrm{U}$, injectate and well $1 \mathrm{~L}$ in the $\mathrm{MC} 2$ as the three endmembers). The two endmember mixture represents injectate migrating upwards to the MC1 through vertical confinement bypass 
pathways. The three endmember represents injectate migrating upwards through the $\mathrm{MC} 2$ to the MC1. Observed conservative ion concentrations closely match the two endmember solution mixture predicted concentrations. The three endmember solution mixture overpredicts ion concentrations.

Figure 4.13 Chloride concentrations of injectate (blue triangles) and well 6U (blue circles graph a), and well $16 \mathrm{U}$ (blue circles graph b) from the MC1 at the SD, and the fraction injectate in each well calculated by the binary mixing model (red diamonds). In graph a, the $f_{\text {inj }}$ is seen increasing over time as $\mathrm{Cl}^{-}$concentrations decrease over time in well 6U. In graph $\mathrm{b}$, the $\mathrm{f}_{\text {inj }}$ for well $16 \mathrm{U}$ appears to remain fairly stable, with a slight increasing trend seen in the post 2006 data.

Figure 4.14 Hypothesized injectate flowpaths to the MC1 at the SD. Aquifer layers not to scale, and the APPZ is omitted to simplify figure. Grey on well diagrams is casing, white is open borehole. Injectate (red arrows) is injected into the Boulder Zone, where it migrates upward due to buoyant flow. Vertical confinement bypass pathways allow buoyant injectate to migrate up to the $\mathrm{MC1}$, bypassing underlying confining layers, as illustrated by well 6 . Injectate excess $\mathrm{CO}_{2}$ allows for porosity enhancement over time, while methanogenesis gradually consumes excess $\mathrm{CO}_{2}$ as injectate migrates upwards. Once introduced into the $\mathrm{MC1}$, injectate flows along horizontal flow paths as it mixes with ambient water, with methanogenesis consuming all excess $\mathrm{CO}_{2}$, resulting in aquifer water becoming oversaturated with respect to $\mathrm{Ca}^{2+}$ (well 13) Well 9 illustrates injectate that has not yet migrated far enough to be detected in the MC1. Well 12 illustrates a vertical confinement bypass pathway to the $\mathrm{MC} 2$, that does not extend up into the $\mathrm{MC} 1$. The shorter migration time to $\mathrm{MC} 2$ is evident in the higher $f_{\text {inj. }}$. No evidence of injectate has been detected in the UFA at either the $\mathrm{ND}$ or the SD, as illustrated by well 3 . 


\section{CHAPTER 1 INTRODUCTION}

Deep well injection into non-potable aquifers has been used in Florida for several decades as an alternative to discharge of treated domestic wastewater to surface waters. These deep aquifers tend to be saline, and the discharge of fresh wastewater into them raises concerns of geochemical reactions as a result of the mixing of the two waters, as well as the buoyant transport of the wastewater upwards into overlying aquifers. Although there has been considerable interest regarding injection of potable fresh water for storage in deep brackish aquifers (Arthur et al, 2001; Renken et al, 2005), little investigation has been conducted regarding the fate and transport of the treated wastewater into deep saline aquifers, as it has been thought that there would be no impact to the overlying aquifers as a result of injection (Meyer, 1989a).

Miami-Dade County Water and Sewer Department (MDWASD), located in southern Florida, currently disposes of 430 million liters per day (MLD) of treated domestic wastewater into a deep saline aquifer at two locations in the county. Deep well injection has been in use in Miami-Dade County since the early 1980's, and water quality data since 1983 has been collected from monitoring wells. The South District Wastewater Treatment Plant (SD), located in southern Miami-Dade County, Florida, was placed into service in 1983, and is currently permitted for the disposal of 367 MLD of treated wastewater. The North District Wastewater Treatment Plant (ND) was placed into service in 1997, and is permitted for 90 MLD of wastewater disposal. Both facilities treat domestic wastewater to above secondary drinking water standards, and dispose the treated wastewater into United States Environmental Protection Agency (USEPA) Class I 
injection wells (Florida Department of Environmental Protection (FDEP) Permit Nos. 61787-014-UC - 61787-017-UC). Both facilities consist of deep injection wells at approximately 855 meters below land surface (bls) and inject treated wastewater into a highly transmissive zone in the saline non-potable aquifer known in south Florida as the Boulder Zone. The Boulder Zone has been thought to be hydrologically separated from overlying aquifers by a 335 meter thick confining unit. However, during the installation of additional monitoring wells at the $\mathrm{SD}$ in 1994 , detection of ammonia-nitrogen $\left(\mathrm{NH}_{3}\right.$ N) at 442 meter bls in the overlying aquifer at a concentration of 7 milligrams per liter $\left(\mathrm{mg} \mathrm{l}^{-1}\right)$, above reported background levels of $0.05 \mathrm{mg} \mathrm{l}^{-1}$ (BC\&E, 1977), have raised doubts regarding the efficacy of the confining unit. Concerns have also been noted regarding water quality impact to overlying aquifers, as these aquifers are used as alternative water supplies via storage of freshwater (aquifer storage and recovery) and blending with potable surficial aquifer water.

A unique opportunity to study the geochemical reactions and migration of injected wastewater was provided by the availability of historical data and the cooperation of MDWASD to collect new data. The current research determines the migration and fate of treated wastewater within native waters of the Floridan Aquifer System in south Florida and the resultant geochemical reactions within the aquifer system.

\section{$1.1 \quad$ Objectives}

Chemical and isotopic data collected from aquifers have been used to interpret source waters and ground-water recharge (Bölke and Denver, 1995, Shapiro et al., 1998, Price et al, 2003; Manning et al., 2005). Effluent injected into the Lower Floridan Aquifer is a 
source of recharge, and should be distinguishable from native Floridan Aquifer water by ion chemistry, stable isotope ratios, dissolved gases, and the presence of tritium. My research uses concentrations of natural occurring stable isotopes $\left({ }^{18} \mathrm{O} /{ }^{16} \mathrm{O},{ }^{2} \mathrm{H} /{ }^{1} \mathrm{H}\right.$, and $\left.{ }^{15} \mathrm{~N} /{ }^{14} \mathrm{~N}\right)$, dissolved gases, concentrations of tritium $\left({ }^{3} \mathrm{H}\right)$ and helium $\left({ }^{3} \mathrm{He}\right)$ isotopes using the ${ }^{3} \mathrm{H} /{ }^{3} \mathrm{He}$ dating technique, and chemical water quality analysis and modeling for the following objectives:

1. Determine the source of ammonium in the Floridan Aquifer, and evaluate the use of ammonium as a conservative tracer of the wastewater.

2. Determine injectate transport mechanisms and migration pathways.

3. Predict the fate of native waters and injectate and any contaminants that have been (or may be) produced as a result of geochemical reaction within the aquifer system.

\subsection{Dissertation Organization}

My dissertation consists of five chapters. Chapter 1 is this introduction. Chapters 2, 3 and 4 are the main chapters, and are intended to stand alone as complete papers. Chapter 5 summarizes the dissertation results, and recommends further areas of research. Chapter 2 (Walsh and Price, 2010, published in Hydrogeology Journal, for copyright release see Appendix B), presents historical groundwater quality collected over 25 years at the South District, and over ten years at the North District. Analysis of conservative ion data indicated injected ammonium behaved conservatively when mixed with ambient groundwater. Transport pathways were distinguished on the basis of ammonium, chloride, and bromide ion concentration ratios, and temperature. Injectate was concluded 
to migrate upwards to overlying aquifers through vertical pathways, bypassing the underlying confining units.

Chapter 3 summarizes the stable isotope, tritium, and dissolved gas data. Injectate was determined to be enriched in $\delta^{15} \mathrm{~N}-\mathrm{NH}_{4}^{+}, \mathrm{CO}_{2}$, the heavier noble gases, and tritium, while depleted in the lighter dissolved gases. These signatures were observed in samples collected from wells with elevated $\mathrm{NH}_{4}^{+}$concentrations. Evidence of methanogenesis and $\mathrm{NH}_{4}^{+}$oxidation reactions were observed in the data. Further evidence of confinement bypass pathways were detected at the South District, while no evidence of these pathways were observed in the data at the North District.

Chapter 4 summarizes the geochemical modeling and speciation using PHREEQC (Parkhurst and Appelo, 1999) and binary mixing models. Results supported the hypothesis of confinement bypass pathways at the South District. Use of a two member mixing model, with ambient water quality from the overlying aquifer and injectate as the endmembers, closely predicted conservative ion concentrations, whereas a three member mixing model including water quality from the underlying aquifers overestimated ion concentrations compared to observed. Geochemical modeling suggested porosity enhancement along vertical flowpaths, increasing the fraction of injectate over time in wells in the vicinity of these pathways. No evidence was again observed for these vertical pathways at the North District.

Chapter 5 summarizes the three main chapters and suggests future research for injection sites. Appendices following Chapter 5 include the copyright release, author guidelines for 
journal publication, water quality data, PHREEQC model input and output files, and the VITA. Historical data records and data collected for my dissertation consist of large data sets, therefore all data are available by contacting Miami-Dade Water and Sewer Department at http://www.miamidade.gov/water/contact.asp. 


\subsection{References}

Arthur, J. D., J. B. Cowart, and A. A. Dabous. 2001. Florida Aquifer Storage and Recovery Geochemical Study: Year Three Progress Report. Open File Report 83 Open File Report 83, Florida Geological Survey, Tallahassee.

BC\&E/CH2MHill. 1977. Drilling and testing of the test-injection well for the MiamiDade Water and Sewer Authority. Contract S-153, BC\&E/CH2M Hill, Gainesville, Florida.

Böhlke, J. K., and J. M. Denver. 1995. Combined use of groundwater dating, chemical, and isotopic analyses to resolve the history and fate of nitrate contamination in two agricultural watersheds, Atlantic coastal plain, Maryland. Water Resources Research 31:2319-2339.

Manning, A. H., D. K. Solomon, and S. A. Thiros. 2005. ${ }^{3} \mathrm{H} /{ }^{3} \mathrm{He}$ age data in assessing the susceptibility of wells to contamination. Ground Water 43:353-367.

Meyer, F. W. 1989a. Hydrogeology, Ground-Water Movement, and Subsurface Storage in the Floridan Aquifer System in Southern Florida. Professional Paper 1403-G, U.S. Geological Survey, Washington, D.C.

Parkhurst, D. L., Appelo, C.A.J. 1999. User's guide to PHREEQC (version 2)-A computer program for speciation, batch-reaction, one-dimensional transport, and inverse geochemical calculations. Water-Resources Investigations Report 994259, U.S. Geological Survey.

Price, R. M., Z. Top, J. D. Happell, and P. K. Swart. 2003. Use of tritium and helium to define groundwater flow conditions in Everglades National Park. Water Resources Research 39:1267.

Renken, R. A., J. Dixon, J. Koehmstedt, A. C. Lietz, S. Ishman, R. L. Marella, P. Telis, J. Rogers, and S. Memberg. 2005. Impact of Anthropogenic Development on Coastal Ground-Water Hydrology in Southeastern Florida, 1900-2000. Circular 1275, U.S. Geological Survey, Reston.

Shapiro, S. D., G. Rowe, P. Schlosser, A. Ludin, and M. Stute. 1998. Tritium-helium 3 dating under complex conditions in hydraulically stressed areas of a buried aquifer. Water Resources Research 34:1165-1180. 


\section{CHAPTER 2 DETERMINATION OF VERTICAL AND HORIZONTAL}

PATHWAYS OF INJECTED FRESH WASTEWATER INTO A DEEP SALINE

AQUIFER (FLORIDA, USA) USING NATURAL CHEMICAL TRACERS

Walsh, V., and R. M. Price. 2010. Determination of vertical and horizontal pathways of injected fresh wastewater into a deep saline aquifer (Florida, USA) using natural chemical tracers. Hydrogeology Journal, 18:1027-1042.

\subsection{Abstract}

Two deep-well injection sites in south Florida, USA, inject an average of 430 million liters per day of treated domestic fresh wastewater into a deep saline aquifer 900 meters below land surface. Elevated levels of $\mathrm{NH}_{3}$ (highest concentration $939 \mu \mathrm{M}$ ) in the overlying aquifer above ambient concentrations (concentration less than $30 \mu \mathrm{M}$ ) were evidence of the upward migration of injected fluids. Three pathways were distinguished on the basis of ammonium, chloride and bromide ratios, and temperature. At the South District Wastewater Treatment Plant, the tracer ratios showed that the injectate remained chemically distinct as it migrated upwards through rapid vertical pathways via densitydriven buoyancy. The warmer injectate $\left(\right.$ mean $\left.28^{\circ} \mathrm{C}\right)$ retained the temperature signal as it vertically migrated upwards, however the temperature signal did not persist as the injectate moved horizontally into the overlying aquifers. Once introduced, the injectate moved slowly horizontally through the aquifer and mixed with ambient water. At the North District Wastewater Treatment Plant, data provide strong evidence of a one-time pulse of injectate into the overlying aquifers due to improper well construction. No evidence of rapid vertical pathways was observed at the North District Wastewater Treatment Plant. 


\subsection{Introduction}

Deep well injection of treated municipal wastewater into non-potable aquifers has been used as an alternative to discharge of wastewater to surface waters for many decades. There are 430 permitted municipal wastewater deep injection wells in the United States, with 163 in Florida alone (USEPA 2008). These deep aquifers tend to be saline, and the discharge of fresh wastewater into them has raised concerns of geochemical reactions as a result of the mixing of the two waters, as well as the buoyant transport of the wastewater upwards into overlying aquifers. Confined brackish aquifers in Florida have been used extensively for aquifer storage and recovery (ASR) of potable freshwater (Arthur et al 2001; Renken et al 2005), and deeper saline aquifers have been used for disposal of waste fluids such as oil brines, industrial water and municipal wastewater (Meyer 1989a; Meyer, 1989b). Aquifer storage and recovery in Florida has been extensively studied as part of the Comprehensive Everglades Restoration Plan (Reese 2002; Mirecki 2004; Mirecki 2006), however little research has been published regarding the fate and transport of the treated wastewater into deep saline aquifers (Meyer 1989a; Haberfeld 1991, Maliva and Walker, 1998; Bloetscher et al 2005; Bloetscher and Muniz 2006; Maliva et al, 2007).

Miami-Dade County Water and Sewer Department (MDWASD), located in southern Florida, currently discharges 430 million liters per day (MLD) of treated domestic wastewater into a saline deep aquifer at two locations in the county. Deep well injection has been in use in Miami-Dade County since the late 1960's. The injection facilities are located in the north and south of the county, separated by 44 kilometers (Figure 2.1). The 
South District Wastewater Treatment Plant (SDWWTP) site was placed into service in 1983, and is currently permitted for the disposal of 367 MLD of treated wastewater. The North District Wastewater Treatment Plant (NDWWTP) site was placed into service in 1997, and is permitted for 90 MLD of wastewater disposal. Both facilities treat domestic wastewater to above secondary drinking water standards, and discharge the treated wastewater into United States Environmental Protection Agency (USEPA) Class I injection wells. The treated wastewater is injected into the Boulder Zone, a highly transmissive interval in the deep saline non-potable Lower Floridan Aquifer. The Boulder Zone has been thought to be hydrologically separated from overlying aquifers by a 335 meter thick confining unit. During the installation of additional monitoring wells at the SDWWTP in 1994, ammonia-nitrogen $\left(\mathrm{NH}_{3}-\mathrm{N}\right)$ was detected at $442 \mathrm{~m}$ depth in the overlying aquifer at a concentration of 411 micromols per liter $(\mu \mathrm{M})$, above reported background levels of $29 \mu \mathrm{M}$ (BC\&E 1977). The detection of $\mathrm{NH}_{3}-\mathrm{N}$ in the aquifers above the Boulder Zone has raised doubts regarding the efficacy of the confining unit and the resultant water quality impact to overlying aquifers, as these aquifers are used as alternative water supplies via storage of freshwater (ASR) and blending with potable surficial aquifer water.

Research has focused on ASR in south Florida (Arthur et al 2001; Reese 2002; Mirecki 2004; Mirecki 2006; Reese and Richardson 2008), however few studies have been conducted regarding the transport and fate of injected effluent into the Boulder Zone, and typically these had to do with the relative risk of deep well injection versus ocean outfall disposal of municipal waste (Englehardt et al 2001; USEPA 2003; Bloetscher et al 2005; 
Bloetscher and Muniz 2006). Recently researchers have studied the transport mechanisms of the observed migrated injectate, and have suggested density-driven buoyant transport mechanism along natural or anthropogenic vertical fractures in the lower aquifers (Maliva and Walker, 1998; McNeill 2000; McNeill 2002; Maliva et al 2007; Walsh and Price 2008). The objective of this study was to determine migration pathways of injectated treated wastewater at two facilities in Miami-Dade County, Florida (SDWWTP and NDWWTP) using historical time series data, and major ion data collected as part of this study. The methodology developed for this study used chloride $\left(\mathrm{Cl}^{-}\right)$, bromide $\left(\mathrm{Br}^{-}\right)$ and $\mathrm{NH}_{3}$ as tracers. The methodology provided a method for estimating transport pathways, and involved no additional collection of data other than what was typically required under federal and state regulatory programs.

Natural inorganic tracers have been used extensively in water resources investigations to trace groundwater flow paths and calculate mixed water ratios (Langmuir 1997; Davis et al 1998; Herczeg and Edmunds 2000). Chloride and $\mathrm{Br}^{-}$commonly are used as they tend to be conservative, and their ratios may also give information as to the source and pathways of water. Studies have been conducted in south Florida (Shinn et al 1994; Paul et al 1997; Corbett et al 2000; Böhlke, J.K. et al 2003) and elsewhere (Kaehler and Belitz 2003; Clark et al 2004), tracing treated wastewater in surficial aquifers, but $\mathrm{NH}_{3}$ was not used as a tracer as it does not behave conservatively in oxic waters. In the present study, a novel application of $\mathrm{Cl}^{-}, \mathrm{Br}^{-}$and $\mathrm{NH}_{3}$ as conservative tracers of injecate was developed as part of mixing models to distinguish pathways between the deep aquifers. Chloride is a natural anion in the Floridan Aquifer System, and its principal source is seawater, as there 
are no evaporite minerals to provide an additional source (Sprinkle, 1989; Reese, 1994).

The seawater source of $\mathrm{Cl}^{-}$in south Florida is thought to be the result of either incomplete flushing of Pleistocene seawater and brackish water intrusion, and/or the result of the cyclic flow driven by thermal upwelling of Holocene intruded seawater (Kohout 1965; Sprinkler 1989; Reese 1994). Bromide (Br) behaves similar to $\mathrm{Cl}^{-}$in groundwater systems (Davis et. al., 1998), and in south Florida the source of $\mathrm{Br}^{-}$in groundwater is similar to that of $\mathrm{Cl}^{-}$although its natural abundances are orders of magnitude less than chloride. The only source of the $\mathrm{NH}_{3}$ is the injectate and therefore it was used to trace transport pathways of the injected wastewater.

\subsection{Geologic and hydrogeologic framework}

The Floridan Aquifer System in southeastern Florida is defined by a vertically continuous sequence of permeable carbonate rocks of Cenozoic age that are hydraulically connected in varying degrees (Miller, 1986). The aquifer matrix consists of carbonate and dolomitic limestones, dating from the Paleocene to the Oligocene epochs. Overlying the FAS are the impermeable sediments of the late Oligocene to Pliocene age Hawthorn Group, a 180 meter thick confining layer of clays, siltstones and silty limestones. The Hawthorn Group separates the Upper Floridan Aquifer from the late Pliocene and Pleistocene formations making up the Surficial Aquifer System which includes the Biscayne Aquifer in south Florida (Figure 2.2). The Biscayne Aquifer is an unconfined surficial aquifer and is the major source of potable water in south Florida (Fish and Stewart 1991) 
The Floridan Aquifer contains several highly permeable and less permeable zones, with zones of highest permeabilities typically occurring at or near unconformities and usually parallel to the bedding planes (Meyer 1989a). Previous studies (Miller 1986; Reese 1994) grouped the Floridan Aquifer System (FAS) grouped into three hydrostratigraphic units (Figure 2.2), the Upper Floridan Aquifer (UFA), the Middle Confining Unit (MCU), and the Lower Floridan Aquifer. Recently the MCU in south Florida has been divided into the Middle Confining Unit One (MC1) and Middle Confining Unit Two (MC2) (Figure 2.2), separated by the Avon Park Permeable Zone (Reese and Richardson 2008), which in south Florida had previously been identified as the Middle Floridan Aquifer. The Upper Floridan Aquifer contains relatively fresh water, less than $10,000 \mathrm{mg} \mathrm{L}^{-1}$ total dissolved solids (TDS). The Lower Floridan Aquifer, consists of seminconfining or leaky micritic limestone and dolomites layers that contain groundwater with compositions approaching sea water (approximately 30,000 $\mathrm{mg} \mathrm{L}^{-1} \mathrm{TDS}$ ). A dolomite confining unit (DCU), a thin confining unit below the MC2 was characterized at the study site by McNeill (McNeill 2000, 2002). The DCU lies above the permeable zone commonly known as the Boulder Zone within the Oldsmar Formation of the Lower Floridan Aquifer. The FAS outcrops along the Straits of Florida, providing a hydraulic connection to the sea (Kohout 1965; Miller 1996; Reese 1994). Transmissivities in the Upper Floridan Aquifer range from 929 to $2.3 \times 10^{4} \mathrm{~m}^{2} \mathrm{~d}^{-1}$ (Meyer 1989; Reese 1994) while transmissivities range from $2.97 \mathrm{x}$ $10^{5} \mathrm{~m}^{2} \mathrm{~d}^{-1}$ to $2.32 \times 10^{6} \mathrm{~m}^{2} \mathrm{~d}^{-1}$ in the Boulder Zone. 


\subsection{Site Descriptions}

The NDWWTP and the SDWWTP consist of deep injection wells that penetrate down to approximately 855 meters. The upper $755 \mathrm{~m}$ of each well is cased to the top of the Boulder Zone. The bottom $100 \mathrm{~m}$ of each injection well is an open hole in the Boulder Zone. Nine such injection wells and three multi-zoned and dual zoned monitoring wells were constructed between 1977 and 1981 at the SDWWTP (Figure 2.3). The multi-zone test well BZ cluster (BZ-1 through 4) was constructed in 1977, and consisted of four telescoping monitoring wells, the deepest of which was BZ-4, cased to the top of the Boulder Zone; the shallowest BZ-1 open to the UFA at a depth of $312 \mathrm{~m}$. The remaining monitoring wells were constructed both at the SDWWTP and NDWWTP using a dual zone design, with an inner steel casing drilled to the deeper interval, and the outer steel casing open to the upper interval. For this paper, well nomenclature indicates the open interval of the dual-casing: "U" represents the upper monitoring interval and "L" represents the lower monitoring interval. Wells 1 and 2 were dual-cased to monitor water quality in the UFA $(\sim 300 \mathrm{~m})$, and the lower confining units $(\sim 550 \mathrm{~m})(\mathrm{CH} 2 \mathrm{MHill}$, 1981). In $1994 \mathrm{NH}_{3}$ was detected above ambient levels in the confining unit at the BZ well cluster (BZ-2 depth $488 \mathrm{~m}$ ), and subsequent investigations by the utility found a leak that resulted from corrosion of the casing in this cluster (MDWASD, 1995). The lower three monitoring intervals of the BZ well cluster were plugged in 1995 to stop the upward migration of injectate through the casing hole, and the confining unit (488 $\mathrm{m}$ ) monitoring interval was redrilled. From 1995 - 1996 nine injection wells and thirteen dual-zoned monitoring wells were constructed on the South District Wastewater Treatment Plant. These monitoring wells were cased to the Avon Park Permeable Zone (APPZ) and the 
MC2, with approximately $30 \mathrm{~m}$ length of open holes in the formations. During the construction of the monitoring wells, $\mathrm{NH}_{3}$ concentrations above ambient levels were found throughout the site. Elevated $\mathrm{NH}_{3}$ concentrations were found in the northwest corner of the site in the $\mathrm{MC} 1$ interval in several wells, but not in the lower MC2 interval of these wells. Elevated levels were found in the MC2 interval in the south side of the site. As a result of the detected $\mathrm{NH}_{3}$ in the confining units, the EPA required purging of the wells that showed elevated concentrations $\mathrm{NH}_{3}$ (Starr et al., 2001) in an attempt to remove the $\mathrm{NH}_{3}$ loading in the impacted intervals. Discontinuous purging of approximately 2100 liters per minute commenced from 1997 to 2000, for the northwest wells $(5 \mathrm{U}, 6 \mathrm{U}, 7 \mathrm{U}, 8 \mathrm{U}, 15 \mathrm{U}$ and $16 \mathrm{U})$ of the APPZ interval, and the south wells $(11 \mathrm{~L}$ and 12L) of the MC2 at the South District Wastewater Treatment Plant (MDWASD 2000).

Injection well construction started at the NDWWTP in 1996. Four injection wells were constructed into the Boulder Zone, and 4 dual-zoned monitoring wells were constructed to the UFA and the APPZ intervals (Figure 2.4). In 1996, effluent was injected in two completed injection wells while one injection well was still under construction, resulting in injectate backflowing into an open borehole at an uncased injection well for five days. Several months after the construction of the wells had been completed, $\mathrm{NH}_{3}$ concentrations were observed to increase in the APPZ interval of the monitoring wells on site. The utility was required to purge the APPZ interval wells from $2003-2004$ for a period of one year (MDWASD, 2005). 


\subsection{Methodology}

Historical data were collected and checked for quality assurance for the NDWWTP and SDWWTP. Data were available from 1983 through 2007 for the SDWWTP, and 1996 2007 for the North District. Data studied as part of the current research included pressure, temperature, $\mathrm{pH}, \mathrm{Cl}^{-}$, sulfate $\left(\mathrm{SO}_{4}{ }^{2-}\right), \mathrm{NH}_{3}$ and nitrate $\left(\mathrm{NO}_{3}{ }^{-}\right)$. The historical data were compiled from the utility monthly operating reports available sporadically from 1983. Summary statistics including mean, median, standard deviation, maximum and minimum were applied to each of the wells' time series data to assess water quality changes over time, and used to compare to ambient water quality data at other locations in south Florida. Most water quality for the Floridan Aquifer in south Florida had been collected as regulatory requirements, which usually included chemical analyses that are used for drinking water quality, and therefore did not include major ion data. Residence time in the Floridan Aquifer System in south Florida is on the order of thousands of years (Meyer 1989a), and it was assumed that because of the depth of the aquifer water quality was in equilibrium and there would be no other cause of perturbations to ambient water quality other than migration of injectate. Time series data that showed large variation over time would indicate non-equilibrium conditions, and therefore not ambient conditions. Abrupt changes in water quality and pressure were observed in the time series data in wells that were purged in 1997. These changes were not observed in wells that were not purged. These changes in water quality and pressure were interpreted as being the result of cross connections developed in the dual zone casings of some of the purged wells, and review of borehole videos of these wells taken in 2004 confirmed holes in the casings of these wells. It could not be determined which interval the data collected from these wells 
represented after the cross connections developed, therefore, data were discarded from the historical series analysis depending on the month it was ascertained the cross connection developed, and the summary statistics were recalculated for these wells.

Floridan Aquifer water samples were collected at the NDWWTP and SDWWTP during 2006 and 2007 as part of the study of major ions and nitrogen species. Thirty-two monitoring wells were sampled at the SDWWTP, and water quality samples were collected from these wells from the UFA, the APPZ, and the Middle Confining Unit Two. At the NDWWTP, samples were collected from four monitoring wells representing the UFA and four wells in the Avon Park Permeable Zone. Temperature, $\mathrm{pH}$, dissolved oxygen, and conductance using an YSI ${ }^{\mathrm{TM}} 556$ MPS were taken from water samples in the field. The YSI instrument was calibrated per the manufacturer's instructions prior to each sampling event. All wells were purged for at least 24 hours prior to sampling to ensure at least three well volumes were evacuated. The wells were sampled through a closed system using a low flow cell and tygon tubing through a disposable, high capacity 0.45 $\mu \mathrm{m}$ in-line filter. Water samples were analyzed for the anions $\mathrm{Br}^{-}, \mathrm{Cl}^{-}, \mathrm{F}^{-}, \mathrm{NO}_{3}^{-}, \mathrm{NO}_{2}^{-}$, and $\mathrm{SO}_{4}{ }^{2-}$ on a DIONEX ${ }^{\circledR}$ ion chromatography system. $\mathrm{HCO}_{3}{ }^{-}$and $\mathrm{CO}_{2}{ }^{-}$were analyzed via manual titration. $\mathrm{NH}_{3}$ was analyzed on a $\mathrm{LACHAT}^{\circledR}$ analyzer 800 , with $\mathrm{NH}_{4}{ }^{+}$then calculated on the basis of $\mathrm{pH}$ and temperature of the sample using the $\mathrm{NH}_{3}$ result (Stumm and Morgan 1996). Cations $\left(\mathrm{Ca}^{2+}, \mathrm{Mg}^{2+}, \mathrm{K}^{+}, \mathrm{Na}^{+}\right.$and $\left.\mathrm{Sr}^{2+}\right)$ were analyzed by inductively coupled plasma (ICP). 


\subsection{Results}

The mean historical data are summarized in Table 2.1 for the SDWWTP, and Table 2.2 for the NDWWTP. Dissolved oxygen, $\mathrm{NO}_{3}{ }^{-}$and $\mathrm{NO}_{2}{ }^{-}$had similar results for both the SDWWTP and NDWWTP sites for the aquifer intervals. Nitrate concentrations were either detected at very low concentrations, or below detectable levels. Nitrite levels were below $1 \mathrm{micromol} / \mathrm{L}(\mu \mathrm{M})$ for all aquifer intervals and in the injectate at the NDWWTP and SDWWTP sites for the historical time series. The injectate had a mean value of $\mathrm{NO}_{3}{ }^{-}$ of $37.9 \mu \mathrm{M}$ at the NDWWTP, and $10.9 \mu \mathrm{M}$ at the SDWWTP for the historical time series. Dissolved oxygen was detected at concentrations less than $1.0 \mathrm{mg} \mathrm{L}^{-1}$ for all aquifer intervals. Dissolved oxygen concentrations for the injectate had results above 3 $\mathrm{mg} \mathrm{L}^{-1}$ at both the NDWWTP and the South District Wastewater Treatment Plant.

\subsubsection{Historical Time Series Results - SDWWTP}

The historical period of record data for the freshwater injectate samples from the SDWWTP (identified as S-EFF) were available from 1991 through 2007 (Table 2.1). Temperature ranged from 21.8 to $31.1^{\circ} \mathrm{C}$, with $27.7^{\circ} \mathrm{C}$ mean. Mean $\mathrm{pH}$ was 6.6 in the historical time series. $\mathrm{NH}_{3}$ ranged from $146.8-1,849.6 \mu \mathrm{M}$, with $889 \mu \mathrm{M}$ mean. $\mathrm{NH}_{3}$ varied seasonally and increased with time (Figure 2.5). Chloride concentrations averaged 2 millimoles/L (mM), with a very small range and standard deviation, indicative of the freshwater source of the injectate. Historical data from 1983 through 2007 from the SDWWTP for the UFA (wells BZ1, 1U, 2U and 3U) were available. Temperature averaged $24^{\circ} \mathrm{C}$, with no significant difference observed between the wells. The range of $\mathrm{pH}$ was from 7.6 to 8.2 in the UFA. Chloride averaged between 21 to $23 \mathrm{mM}$, while $\mathrm{NH}_{3}$ 
means ranged between $10-13$ micromols. The summary statistics for the water quality samples collected from the UFA showed consistent values, with no discernable variation over time. Historical data from 1994 through 2007 from wells open to the APPZ at the SDWWTP (wells 5U, 6U, 7U, 8U, 9U, 10U, 11U, 12U, 13U, 14U, 15U, 16U) were available. Mean temperatures ranged between 23.1 to $24.9^{\circ} \mathrm{C}$ in these wells. There was little variation observed in the $\mathrm{pH}$ in the APPZ samples, but the mean $\mathrm{pH}$ of 7.6 was lower than the mean $\mathrm{pH}$ in the Upper Floridan Aquifer. Almost all of the wells showed variation in $\mathrm{NH}_{3}$ concentrations over time. Mean values of $\mathrm{NH}_{3}$ in these wells ranged from $35 \mu \mathrm{M}$ in well $10 \mathrm{U}$ to $545 \mu \mathrm{M}$ in well 6-upper. Well $6 \mathrm{U}$ showed an increasing trend with time in $\mathrm{NH}_{3}$ that was observed to be similar to the increasing trend of $\mathrm{NH}_{3}$ in the injectate (Figure 2.5). The spread between the $5^{\text {th }}$ and $95^{\text {th }}$ percentile was the greatest in wells $6 \mathrm{U}$ and 12-upper. Only wells $9 \mathrm{U}, 10 \mathrm{U}$ and $13 \mathrm{U}$ showed little variation in $\mathrm{NH}_{3}$ over time. Mean concentrations of $\mathrm{Cl}-$ in wells $6 \mathrm{U}$ and $7 \mathrm{U}$ were 76 and 73 millimols. Wells in the MC2 were open to intervals varying in depth from $481 \mathrm{~m}$ to $551 \mathrm{~m}$. Mean temperature values ranged from 22.9 to $24.2 \mathrm{C}^{\circ}$ in all wells, with the exception of a mean value of $25.4 \mathrm{C}^{\circ}$ in wells $\mathrm{BZ2}$ and 12-lower. Mean $\mathrm{pH}$ values fell within a 7.3 to 7.6 range. Mean $\mathrm{NH}_{3}$ concentrations showed two groupings. Wells BZ2, 10L, 11L and 12L exhibited concentrations of 106, 141, 417 and $676 \mu \mathrm{M}$ respectively. The remainder of the wells exhibited mean $\mathrm{NH}_{3}$ concentrations of less than 55 micromols. Chloride concentrations for wells $10 \mathrm{~L}, 11 \mathrm{~L}$ and $12 \mathrm{~L}$ were 429 , 193, and $57 \mathrm{mM}$ respectively; the remainder of the wells had mean concentrations greater than $508 \mathrm{mM}$ (exception is BZ-2, whose $\mathrm{Cl}^{-}$concentration of $133 \mathrm{mM}$ reflects the shallower depth of this well with the open interval in the lower brackish water zone of the Floridan Aquifer). Data collected 
from well 12L were similar to data collected for wells for $6 \mathrm{U}$ and 7-upper. These wells had high $\mathrm{NH}_{3}$ concentrations, with low $\mathrm{Cl}^{-}$and $\mathrm{SO}_{4}{ }^{-}$concentrations. Historical data were available from 1983 through 1994 for the Boulder Zone interval (well BZ4). The mean $\mathrm{pH}$ and temperature values were 7.2 and $24.9 \mathrm{C}^{\circ}$, respectively. Mean $\mathrm{NH}_{3}$ concentration was $634 \mu \mathrm{M}$, and showed apparent seasonal variation and increasing trend over time, and was similar to the injectate historical time series (Figure 2.5). The mean $\mathrm{Cl}^{-}$concentration was $3 \mathrm{mM}$, similar to the mean $\mathrm{Cl}^{-}$concentration of $2 \mathrm{mM}$ for the injectate.

\subsubsection{Historical Time Series Results - NDWWTP}

The historical period of record data from 2002 through 2007 for freshwater injectate samples (N-Eff) at the NDWWTP were available. Temperature ranged from 22 to $34{ }^{\circ} \mathrm{C}$, with $28{ }^{\circ} \mathrm{C}$ mean temperature. The mean $\mathrm{pH}$ of 6.5 was similar mean to the SDWWTP injectate. $\mathrm{NH}_{3}$ ranged from $210-3764 \mu \mathrm{M}$, with a mean of $819 \mu \mathrm{M}$ and a large standard deviation, indicative of the apparent seasonality similar to the South District Wastewater Treatment Plant. Chloride concentrations ranged from $0.8 \mathrm{mM}$ to $113.1 \mathrm{mM}$, with a mean $20 \mathrm{mM}$, slightly higher than the mean concentration of the SDWWTP injectate.

Historical data were available from 1996 through 2007 for wells open to the Upper Floridan Aquifer (N-1U, N-2U, N-3U and N-4U). Mean temperature averaged $23{ }^{\circ} \mathrm{C}$ in these wells, with no significant difference observed between the wells. Mean values of $\mathrm{pH}$ were in the 7.6 to 7.8 range. Chloride mean concentrations ranged between 66.2 and 73.7 mmols. Ammonia mean concentrations ranged between 17 to $18 \mu$ mols. Concentrations for the UFA water quality samples for the NDWWTP showed consistent values, with no discernable variation over time. Historical data were available from 1996 
through 2007 for wells open to the Avon Park Permeable Zone (N-1L, N-2L, N-3L, and $\mathrm{N}-4 \mathrm{~L}$ ). Temperature mean values were $22 \mathrm{C}^{\circ}$. Analysis of historical $\mathrm{NH}_{3}$ data indicates increasing concentrations of $\mathrm{NH}_{3}$ starting in late 1997 (Figure 2.6). $\mathrm{NH}_{3}$ concentrations appeared to have reached a peak concentration of $408 \mu \mathrm{M}$ in well N-1L in July 2001, and steadily declined thereafter to concentrations ranging from $200 \mu \mathrm{M}$ to $250 \mu$ mols. Wells N-2L, N-3L and N-4L show similar patterns as well N-1L, but with lowered and delayed peak concentration values. $\mathrm{NH}_{3}$ concentrations are observed to increase scatter after 2003, which corresponds to when purging commenced at the NDWWTP. Once purging ceased in $2004, \mathrm{NH}_{3}$ concentrations in wells varied between $150-300 \mu$ mols. The $\mathrm{Cl}^{-}$mean concentrations ranged from 368 to 409 mmols. Chloride in these wells exhibited variation over time, and analysis of the time series indicated that as $\mathrm{NH}_{3}$ concentrations increased, $\mathrm{Cl}^{-}$concentrations decreased (Figure 2.6). The time series data for the lower wells were revised to remove data after $\mathrm{NH}_{3}$ concentrations were observed to increase in each well in order to determine ambient concentrations in the APPZ. Revised $\mathrm{NH}_{3}$ mean concentrations ranged from $18-24 \mu \mathrm{M} ; \mathrm{Cl}^{-}$mean concentrations ranged from $441-461$ mmols. Very little variation was observed in $\mathrm{NH}_{3}$ and $\mathrm{Cl}^{-}$mean concentrations after the time series data were removed.

\subsubsection{Major Ion Data Collection Results}

Major ions were collected for this study from 2006 - 2007 (Table 2.3). Data from wells at the SDWWTP site that exhibited cross connections were removed from this analysis. Data collected from the SDWWTP UFA exhibited very little variation between wells, and were similar to the historical time-series data, with low cation and anion 
concentrations. For the APPZ wells, $\mathrm{NH}_{4}{ }^{+}$mean concentrations could be combined into three groups: wells $9 \mathrm{U}, 10 \mathrm{U}$ and $13 \mathrm{U}$ at $\mathrm{NH}_{4}{ }^{+}$mean concentrations of 60,67 and $143 \mu \mathrm{M}$ respectively; wells $14 \mathrm{U}$ and $16 \mathrm{U}$ at 497 and $439 \mu \mathrm{M}$; well $6 \mathrm{U} 823 \mu$ mols. Cation and anion mean concentrations showed a similar grouping as the $\mathrm{NH}_{4}^{+}$concentration grouping, with well $6 \mathrm{U}$ consistently grouping independently, and with increasing $\mathrm{NH}_{4}^{+}$ concentrations correlating to decreasing ion concentrations. The $\mathrm{MC} 2$ mean $\mathrm{NH}_{4}{ }^{+}$ concentrations could also be combined into three groups: well 12L at a mean $\mathrm{NH}_{4}^{+}$ concentration of $765 \mu \mathrm{M}$; wells BZ-2, 10L and $13 \mathrm{~L} \mathrm{NH}_{4}^{+}$at mean concentrations 176 , 200 and $108 \mu \mathrm{M}$ respectively; the remainder wells at $\mathrm{NH}_{4}{ }^{+}$concentrations below 10 $\mu$ mols. Cation and anion concentrations could be combined in the same 3 groups as the $\mathrm{NH}_{4}{ }^{+}$groups, with lower ion mean concentrations observed for BZ-2, 10L and 13L, and much lower ion concentrations observed in well 12-lower. As with well 6U in the MC1, well $12 \mathrm{~L}$ in the MC2 consistently grouped independently.

The NDWWTP wells open to the UFA $(351-385 \mathrm{~m})$ exhibited very little variation in field measurements and mean concentrations between wells, and were similar to the historical time series. The interval $(430-461 \mathrm{~m})$ in the APPZ at the NDWWTP also showed little variation, with mean $\mathrm{NH}_{4}{ }^{+}$concentrations $(215-295 \mu \mathrm{M})$ and mean concentrations of $\mathrm{Cl}^{-}(371-386 \mathrm{mM})$ varying little between wells.

\subsubsection{Ternary Diagram}

The typical $\mathrm{Cl}^{-} / \mathrm{Br}^{-}$ratio for seawater is about 290 (Davis et al 1998), and most of the $\mathrm{Cl}^{-} / \mathrm{Br}^{-}$ratios at both sites were within that range, with no discernable differences. Quite often the addition of a third water quality member could enhance the understanding of the 
data, and this was the case with using $\mathrm{NH}_{4}{ }^{+}$as the third end-member. $\mathrm{NH}_{4}{ }^{+}, \mathrm{Cl}^{-}$and $\mathrm{Br}^{-}$ data were plotted on a ternary diagram, with data normalized to 100 percent. Typical seawater and freshwater $\mathrm{NH}_{4}{ }^{+}, \mathrm{Cl}^{-}$and $\mathrm{Br}^{-}$values after Hem (1985) were also plotted for comparison. Water quality at the NDWWTP clustered into three distinct groups, with two groups based on depth of the interval sampled and the third the injectate (Figure 2.7). The ambient aquifer data plot close to seawater. The injectate data plotted off in the lower left hand corner due to the large $\mathrm{NH}_{4}{ }^{+}$concentrations. At the SDWWTP, three aquifer groupings were observed. Ambient well data from the MC2 plotted similar to seawater. Ambient well data from the UFA plotted slightly towards freshwater. Data from wells that showed elevated $\mathrm{NH}_{4}{ }_{4}$ plotted in a line towards the injectate, with groundwater data from $6 \mathrm{U}$ and $12 \mathrm{~L}$ plotting very close to the injectate. This line represents the evolution of the water quality of these wells towards the injectate water quality, and does not show any evolution of more saline water into the higher intervals in the aquifer.

\subsubsection{Mixing End-member Models}

End-member mixing models of wells $6 \mathrm{U}, 12 \mathrm{~L}$ and $10 \mathrm{~L}$ represented the results obtained for all wells at the South District Wastewater Treatment Plant (Figure 2.8). Well 6U and $12 \mathrm{~L}$ showed the progressive freshening of water and increasing $\mathrm{NH}_{3}$ concentrations towards the injectate end-member (Figure 2.8). There was little mixing from the saline end-member towards the brackish end member in well $6 \mathrm{U}$, and almost all of the mixing was towards the injectate end-member. Both $6 \mathrm{U}$ and 12L showed large changes in concentrations from their original end-members over time. Well 10L showed a different pattern than $6 \mathrm{U}$ and $12 \mathrm{~L}$, with gradual freshening of the saline water towards the injectate 
end-member. The mixing was towards to the lower range of the injectate end-member, and there were no large changes in concentrations of either $\mathrm{NH}_{3}$ or $\mathrm{Cl}^{-}$from the saline end-member. Well N-1L at the NDWWTP end-member mixing model showed a different pattern than the SDWWTP (Figure 2.9). Clustering of the $\mathrm{NH}_{3} / \mathrm{Cl}^{-}$ratios were

distinguished based on time. The $\mathrm{NH}_{3} / \mathrm{Cl}^{-}$ambient ratio can clearly be seen on Figure 2.9, and lies along the saline end-member. As the concentrations of $\mathrm{NH}_{3}$ increased in time to the peak concentration, the $\mathrm{NH}_{3} / \mathrm{Cl}^{-}$ratios showed 2 distinct clusters. Initially the $\mathrm{NH}_{3} / \mathrm{Cl}^{-}$ ratio showed gradual increasing in $\mathrm{NH}_{3}$ with little change in $\mathrm{Cl}^{-}$from ambient concentrations. There was a rapid change in the $\mathrm{NH}_{3} / \mathrm{Cl}^{-}$ratio as $\mathrm{NH}_{3}$ reached the peak concentrations. Once the peak was reached, the $\mathrm{NH}_{3} / \mathrm{Cl}^{-}$ratios slowly declined in time.

\subsection{Discussion}

The Floridan Aquifer System was sampled by others at different sites in south Florida and Table 2.4 summarized these data. Wells identified as WWF were monitoring wells installed as part of the MDWASD ASR system west of the NDWWTP and South District Wastewater Treatment Plant (CH2MHill, 1998). The ASR systems were not in use during the time of this study. Wells designated as "FPL" were tests wells installed into the Floridan Aquifer System approximately ten kilometers south from the South District (Dames and Moore, 1975; Florida Partners, 2006). For comparison to the present study the data from these sites were assumed to represent ambient water quality concentrations, as no injection activities had occurred at these sites. Wells in this study that exhibited little variation in the time series data and had low $\mathrm{NH}_{3}$ concentrations were compared to the data from these other sites. Although direct comparisons were difficult due to the 
varying aquifer open intervals from which these samples were collected, some generalizations can be made. Ammonia or $\mathrm{NH}_{4}{ }^{+}$concentrations from these wells were below $29 \mu$ mols. Chloride concentrations increased with depth of the sampled intervals, and were similar in concentrations to wells in this study of approximately the same aquifer interval. Nitrate concentrations were below $1 \mu \mathrm{M}$, similar to data collected for this study. On the basis of comparisons with water quality from these other sites, the revised time series water quality data that had mean $\mathrm{NH}_{3}$ concentrations below $30 \mu \mathrm{M}$ were assumed to be ambient aquifer water, with no influence of injectate. All the wells in the UFA at the SDWWTP were considered ambient, and most of the wells in the MC2 at the SDWWTP were considered ambient with the exception of 10L, 11L and 12-lower. All of the wells in the APPZ at the SDWWTP had $\mathrm{NH}_{3}$ concentrations above ambient levels, with well 9U the lowest. Time series data at the NDWWTP indicated that all of the wells open to the UFA were considered ambient, and the data from wells open to the APPZ were ambient prior to the observed increase in $\mathrm{NH}_{3}$ concentrations.

Ambient $\mathrm{Cl}^{-}$concentrations from this study showed brackish, transitional, and saline zones in the Floridan Aquifer System for the SDWWTP and NDWWTP as defined by Reese (1994). Although there were only two sample depths at the NDWWTP, the top of the saline zone at the north appears to be higher than at the South District Wastewater Treatment Plant. Mean temperatures at the NDWWTP were cooler than at the SDWWTP, with an average of $23^{\circ} \mathrm{C}$ for both intervals. The NDWWTP lies closer to the Florida Straits, and the cooler temperatures at that site may be due to closer proximity to open seawater. Wells that showed a higher concentration of $\mathrm{NH}_{3}$ at the SDWWTP showed 
higher temperatures (example Well 12L), whereas at the NDWWTP no change in temperature was noted with increasing $\mathrm{NH}_{3}$ concentrations.

On the basis of the current study, introduced nitrogen from the injectate into the Floridan Aquifer is mostly in the form of ammonium, and is consistent with eH-pH diagrams for nitrogen (Stumm and Morgan 1996) that in most natural environments any ammonia-N would have the form of ammonium (Hem 1985). No relationship was observed in the historical data or data collected as part of this study between $\mathrm{NH}_{3}$ and nitrate. No change from ambient $\mathrm{NO}_{3}{ }^{-}$concentrations was observed for wells that had elevated $\mathrm{NH}_{3}$ concentrations. The reduced form of nitrogen $\left(\mathrm{NH}_{4}{ }^{+}\right)$was not oxidized once introduced in the anoxic aquifer at either site, and was conserved in the aquifer in this reduced state. Any introduced oxidized form of nitrogen $\left(\mathrm{NO}_{3}{ }^{-}\right)$from the injectate that was reduced would result in insignificant changes in $\mathrm{NH}_{4}{ }^{+}$concentrations, as $\mathrm{NO}_{3}{ }^{-}$concentrations are two to three orders of magnitude less than ammonium. The elevated concentrations of $\mathrm{NH}_{4}{ }^{+}$in the Floridan aquifer at the two sites are interpreted as the result of the upward migration of the injectate. Once introduced into the aquifer, $\mathrm{NH}_{4}{ }^{+}$appeared to have behaved conservatively.

At least two pathways of injectate were distinguished on the basis of the analysis of the natural tracers at the South District Wastewater Treatment Plant. One pathway at the SDWWTP appeared to have rapid vertical pathways from the Boulder Zone up to the APPZ, with little mixing of ambient waters as it migrated upward. These vertical conduits did not appear to extend up to the Upper Floridan Aquifer. The pathway is identified at wells $6 \mathrm{U}$ and $14 \mathrm{U}$ in the APPZ, and well $12 \mathrm{~L}$ in the Middle Confining Unit 
Two. It may be present at well $8 \mathrm{U}$ in the APPZ however the development of cross connection in well $8 \mathrm{U}$ compromised data interpretation. Ammonium concentrations in these wells were within the range of injectate $\mathrm{NH}_{4}{ }^{+}$concentrations. Chloride concentrations in these wells were also very close to injectate $\mathrm{Cl}^{-}$concentrations. The mixing models for these wells show a mixing pathway almost directly towards the injectate end-member, with no mixing from the lower MC2 interval observed for wells $6 \mathrm{U}$ and 14-upper. Wells that showed the highest concentrations of $\mathrm{NH}_{3}$ at the SDWWTP also showed higher temperatures, with the temperature signal of the warmer injectate observed in well $12 \mathrm{~L}$ (mean temperature of $28^{\circ} \mathrm{C}$ ) in the $2006-2007$ sampling period. Well $12 \mathrm{~L}$ in the MC2 is much closer to the Boulder Zone than the APPZ wells, and higher injectate temperatures persist into the MC2. Perhaps because of the longer travel times to the APPZ the temperature signal was muted but still visible in the Avon Park Permeable Zone. Ion data for these wells showed freshening of the water quality. These wells showed a density-driven buoyant rapid vertical advective pathway and transport of the injectate as a distinct water body, with little mixing of native waters as it migrated upwards. The rapid pathways could be the result of construction related events, such as drifting boreholes, or the result of structural anomalies such as fracturing and karst features that would vertically connect aquifers and provide high hydraulic conductivity transport pathways through confining units. Migration of saline waters from the Lower to Upper Floridan Aquifer as a result of such structural anomalies have been reported for northeastern and central Florida (Flocks et al 2001; Spechler 2001), where the Floridan Aquifer System lies much closer to the surface. Upward fluid migration of injected fluids in a Palm Beach County, Florida, deep well injection facility had been detected above the 
confining zone between the injection zone and the overlaying monitoring zone, and was attributed to fractured dolostone comprising the majority of the confining zone strata (Maliva et al 2007), however no fracturing of the confining strata at either the NDWWTP or the SDWWTP has been reported. McNeill suggested that as wells located on the northwest side of the SDWWTP were cased above the DCU in the LFA, this would be a possible cause of the buoyant upward migration of injected fluids through the more permeable units above the DCU through isolated vertical flow paths, bypassing the Middle Confining Unit Two (McNeill, 2000, 2002).

The second pathway was suggested by the grouping of well data observed in wells $15 \mathrm{U}$, 16U, BZ2, 10L and 11-lower. The well data from this group had no significant correlation between $\mathrm{NH}_{3}$ and chloride. The mixing models for these well data showed a slow evolution of water quality towards the lower average of the injectate end-member with time. These wells showed a slight temperature increase, but no clear temperature signal was distinguished in these wells. Ion data did not show a freshening of the water quality, with little difference seen between ambient ion concentrations and concentrations from these wells. Other studies (Böhlke et al, 2006) have indicated that $\mathrm{NH}_{3}$ transport can be retarded by a factor of 3-6 in an aquifer, with a $\mathrm{NH}_{3}$ cloud persisting in an aquifer after the more mobile constituents were flushed out, if the aquifer remained under suboxic conditions. At the SDWWTP it appears that there was still $\mathrm{NH}_{3}$ loading into the aquifer via rapid vertical pathways, with increasing $\mathrm{NH}_{3}$ concentrations over time. The data from this well grouping may indicate that once $\mathrm{NH}_{3}$ was introduced into an aquifer interval, it 
traveled horizontally at a much slower rate, with the freshwater injectate substantially diluted, and not flushed out, as freshwater continued to migrate upwards.

Four discrete injectate plumes were delineated at the SDWWTP on the basis of the transport pathways. The first plume (plume 1 in Figure 2.10), located on the northeast of the site, was associated with the BZ-4 well, which provided a pathway up into the APPZ until it was plugged. The plume slowly migrated to the surrounding areas mainly via diffusion, as evidenced by slowly increasing $\mathrm{NH}_{3}$ concentrations, but no change in $\mathrm{Cl}^{-}$ concentrations. The second plume was located on the northwest corner of the site in the Avon Park Permeable Zone (plume 2). The plume was detected in the APPZ, with no detection of it in the lower MC2, indicating a direct pathway to the APPZ bypassing the Middle Confining Unit Two. This pathway seemed to persist, with concentrations of $\mathrm{NH}_{3}$ increasing with time similar to concentration levels of the injectate. The plume was a chemically distinct water body, with little mixing of native waters. The third plume located at well 14U (plume 3) may be a distinct plume, but it may also be in connection with plume two. No monitoring wells of the same interval as well $14 \mathrm{U}$ are in the vicinity, so extent of this plume could not be determined. The fourth plume was located on the south side of the site in the Middle Confining Unit Two (plume 4). All four plumes appeared to have the same initial transport mechanism up from the Boulder Zone through high hydraulic conductivity pathways, with data from plumes 2,3 and 4 indicating these pathways still persist.

The data collected from the NDWWTP indicate different transport mechanisms than the South District Wastewater Treatment Plant. The temperature signal of the warmer 
injectate was not observed in wells with elevated concentrations of ammonium. Water quality showed no evolution towards the injectate plot in the ternary diagram. The mixing model showed two mixing patterns - one towards the injecate end-member before purging, and one towards the ambient end-member once purging ceased. As observed in the time series $\mathrm{NH}_{3}$ data, $\mathrm{NH}_{3}$ concentrations were first observed to increase in well $\mathrm{N}$ $1 \mathrm{~L}$, the well that was within thirty meters of the uncased injection well, and concentrations peaked at $341 \mu \mathrm{M}$, well below the mean $\mathrm{NH}_{3}$ concentration of the injectate. Unlike the increasing $\mathrm{NH}_{3}$ concentrations observed at the SDWWTP that are the result of rapid vertical migration pathways, once $\mathrm{NH}_{3}$ concentrations at the NDWWTP peaked, they have since decreased with time. All four NDWWTP lower wells have shown very similar water quality since 2004 , when purging ceased at the North District Wastewater Treatment Plant. Both the time series analysis and the data collected as part of this study in 2006 and 2007 appear to indicate a one-time pulse of injectate water into the APPZ, and this pulse of injectate was still migrating through the aquifer in the direction of regional flow. There is no geochemical evidence of a continuing source of $\mathrm{NH}_{3}$ at the NDWWTP, however due to retardation as discussed above the $\mathrm{NH}_{3}$ plume may long persist in the suboxic aquifer (Böhlke et al 2006).

\subsection{Conclusions}

Chloride, bromide and ammonia were used to understand the pathways and transport mechanisms of injected wastewater into the deep saline Boulder Zone in the Floridan Aquifer System. The injectate source was treated freshwater, with elevated levels of ammonia. The water quality of the injectate was chemically and physically distinct from 
ambient Floridan Aquifer System, and these distinctions were used to determine the possible transport pathways. At the SDWWTP, four injectate plumes were identified, and two pathway mechanisms were identified: density-driven buoyant vertical flow, and slower horizontal flow. At the NDWWTP one plume was identified, and appeared to be a result of a one-time pulse injection. At the SDWWTP, the injectate may first have migrated upwards through discrete vertical pathways from the Boulder Zone to the Middle Confining Unit, with the freshwater injectate migrating upwards through saline water as a chemically distinct water body. The four plumes identified at the SDWWTP appear to have originated via this pathway. Once introduced in the higher aquifer intervals, the transport mechanism appeared to be horizontal flow with mixing of ambient waters. The rapid vertical pathways did not appear to extent up to the Upper Floridan Aquifer. At the NDWWTP, the elevated levels of $\mathrm{NH}_{3}$ in the lower Middle Confining Unit appeared to be the result of a construction incident, where a pulse of injectate water backflowed into an uncased injection well, providing a pathway to the upper interval. Once introduced into the upper aquifer interval, the plume slowly migrated with the regional flow within the aquifer. No evidence of rapid vertical pathways was observed at the North District Wastewater Treatment Plant. During the course of this study, it became clear that purging of the wells had unintended consequences for the South District Wastewater Treatment Plant. Cross connections developed in several wells between the upper and lower monitoring zones either during or after purging, and these cross connections have compromised water quality data in these wells. Although it could not be determined from this study, these cross connections may provide pathways of injectate 
into layers in the aquifer that had not been previously affected by upward migrating injectate. 
Arthur, J. D., J. B. Cowart, and A. A. Dabous. 2001. Florida Aquifer Storage and Recovery Geochemical Study: Year Three Progress Report. Open File Report 83 Open File Report 83, Florida Geological Survey, Tallahassee.

BC\&E/CH2MHill. 1977. Drilling and testing of the test-injection well for the MiamiDade Water and Sewer Authority. Contract S-153, BC\&E/CH2M Hill, Gainesville, Florida.

Bloetscher, F., and A. Muniz. 2006. Preliminary Modeling of Class I Injection Wells in Southeast Florida. Ground Water Protection Council 2006 Annual Meeting Proceedings, Miami, FL.

Bloetscher, F., J. D. Englehardt, D.A. Chin, J.B. Rose, G. Tchobanoglous, V.P. Amy, and S. Gokgoz. 2005. Comparative assessment of municipal wastewater disposal methods in southeast Florida. Water Environmental Research 77: 480 - 490.

Böhlke, J. K., E. Shinn, C. Reich, and A. Tihansky. 2003. Origins and isotopic characteristics of dissolved nitrogen species in ground water, imported domestic water, and wastewater in the Florida Keys. in Greater Everglades Ecosystem Restoration.

Böhlke, J. K., Smith, R.L., and D.N. Miller. 2006. Ammonium transport and reaction in contaminated groundwater: Application of isotope tracers and isotope fractionation studies. Water Resources Research 42. doi:10.1029/2005WR004349.

CH2MHill. 1981. Drilling and Testing of the 8 injection wells and the 3 monitoring wells for the South District Regional Wastewater Treatment Plant of the Mimi-Dade Water and Sewer Authority.

CH2MHill. 1998. Engineering Report of the Construction and Testing of the Aquifer Storage and Recovery (ASR) System at the MDWASD West Wellfield. Miami, $\mathrm{Fl}$,

Corbett, D.R., Kump, L., Dillon, K., Burnett, W., and J. Chanton. 2000. Fate of wastewater-borne nutrients under low discharge conditions in the subsurface of the Florida Keys, USA. Marine Geochemistry 69: 99 - 115.

Clark, J.F., Bryant Hudson, G., Lee Davisson, M., Woodside, G., and R. Herndon. 2004. Geochemical Imaging of Flow Near an Artificial Recharge Facility, Orange County, California. Ground Water 42: 167- 174.

Dames and Moore. 1975. Floridan Aquifer Water Supply Investigation. Turkey point Area - Miami-Dade County, Florida. 
Davis, S. N., Whittemore, D.O., and J. Fabryka-Martin. 1998. Uses of Chloride/Bromide Ratios in Studies of Potable Water. Ground Water 36: 338 - 350.

Englehardt, J.D., Amy, V.P., Bloetscher, F., Chinn, D.A., Fleming, L.E., Gokgoz, S., Solo-Gabriele, H., Rose, J.B., and G. Tchoaboglous. 2001. Comparative Assessment of Human and Ecological Impacts for Municipal Wastewater Disposal Methods in Southeast Florida: Deep Wells, Ocean Outfalls, and Canal Discharges. University of Miami, Coral Gables, FL.

Fish, J.E., and Stewart, Mark, 1991. Hydrogeology of the surficial aquifer system, Dade County, Florida. U.S. Geological Survey Water-Resources Investigations Report 90-4108, 50 p, 11 pls.

Flocks, J.G., Kindinger, J.L., Davis, J.B., and P. Swarzenski. 2001. Geophysical Investigations of Upward Migrating Saline Water from the Lower to upper Floridan Aquifer, Central Indian River Region, Florida. In U.S. Geological Survey Karst Interest Group Proceedings, Water-Resources Investigations Report 01-4011, p. 135 - 140.

Haberfeld, J.L. 1991. Hydrogeology of effluent disposal zones, Floridan aquifer, South Florida. Ground Water 29:186-190.

Herczeg, Al.L., and W.M. Edmunds. 2000. Inorganic ions as tracers. In Environmental Tracers in Subsurface Hydrology, ed. P.G. Cook and A.L. Herczeg, 31 - 78. Kluwer Academic Publishers, Norwell, Mass.

Hem, J. D. 1985. Study and Interpretation of the Chemical Characteristics of Natural Water. Water-Supply Paper 2254, U.S. Geological Survey, Alexandria.

Kaehler, C.A., and K. Belitz. 2003. Tracing Reclaimed Water in Menifee, Winchester, and Perris-South Ground-Water Subbasins, Riverside County, California. WaterResources Investigations Report 03-4039. U.S. Geological Survey, Sacramento, CA.

Kohout, F. A. 1965. A hypothesis concerning cyclic flow of salt water related to geothermal heating in the Floridan aquifer. Trans. N.Y. Acad. Sci., Ser. II 28:249271.

Langmuir, D. 1997. Aqueous Environmental Geochemistry. Prentice-Hall, Inc., Upper Saddle River.

Maliva, R.G.,and C.W. Walker. 1998. Hydrogeology of deep-well disposal of liquid wastes in southwestern Florida, USA. Hydrogeology Journal: 6.

Maliva, R.G., Guo, W., and T. Missimer. 2007. Vertical Migration of municipal wastewater in deep injection well systems, South Florida, USA. Hydrogeology Journal: 15 . 
McNeill, D.F. 2000. Final Report: A Review of Upward Migration of Effluent Related to Subsurface Injection at Miami-Dade Water and Sewer South District Plant: McNeill Geological Services Inc., Miami, FL.

McNeill, D.F. 2002. A Geological Review of the Confining Capability of a Regional Dolomite Unit: Application to the MDWASD South District WWTP. McNeill Geological Services Inc., Miami, FL.

Meyer, F. W. 1989a. Hydrogeology, Ground-Water Movement, and Subsurface Storage in the Floridan Aquifer System in Southern Florida. Professional Paper 1403-G, U.S. Geological Survey, Washington, D.C.

Meyer, F. W. 1989b. Subsurface storage of liquids in the Floridan Aquifer System in south Florida. Open-File Report 88-477 Open-File Report 88-477, U.S. Geological Survey, Tallahassee, Fl.

Miami-Dade Water and Sewer Department.1995. Plugging and Abandonment of BZ Well Cluster, South District Wastewater Treatment Plant, Miami-Dade Water and Sewer Department, Dade County, Florida.

Miami-Dade Water and Sewer Department. 2000. Monitoring well purging report for South District Wastewater Treatment Plant, Miami-Dade Water and Sewer Department, Dade County, Florida. Miami-Dade Water and Sewer Department, Miami, Florida.

Miami-Dade Water and Sewer Department. 2005. Monitoring well purging report for North District Wastewater Treatment Plant, Miami-Dade Water and Sewer Department, Dade County, Florida. Miami-Dade Water and Sewer Department, Miami, Florida.

Miller, J. A. 1986. Hydrogeologic Framework of the Floridan Aquifer System in Florida and in Parts of Georgia, Alabama, and South Carolina. Professional Paper 1403-B Professional Paper 1403-B, U.S. Geological Survey, Washington, D.C.

Mirecki, J.E. 2004. Water-Quality Changes During Cycle Tests at Aquifer Storage Recovery (ASR) Systems of South Florida. ERDC/EL TR-04-8. US Army Corps of Engineers.

Mirecki, J.E. 2006. Geochemical Models of Water-Quality Changes During Aquifer Storage Recovery (ASR) Cycle Tests, Phase I: Geochemical Models Using Existing Data. ERDC/EL TR-06-8. US Army Corps of Engineers.

Paul, J.H., Rose, J.B., Jiang, S.C., Zhou, X., Cochran, P., Kellogg, C., Kang, J.B., Griffin, D., Farrah, S., and Lukasik, J. 1997. Evidence for groundwater and surface marine water contamination by waste disposal wells in the Florida Keys. Water Resources 31: 1448-1454. 
Reese, R. S. 1994. Hydrogeology and the Distribution and Origin of Salinity in the Floridan Aquifer System, Southeastern Florida. Water-Resources Investigations Report 94-4010, U.S. Geological Survey, Tallahassee, Florida.

Reese, R.S. 2002. Inventory and review of aquifer storage and recovery in southern Florida. Water-Resources Investigations Report 02-4036, U.S. Geological Survey Water, Tallahassee, Florida.

Reese, R.S, and E. Richardson. 2008. Synthesis of the Hydrogeologic Framework of the Floridan Aquifer System and Delineation of a Major Avon Park Permeable Zone in Central and Southern Florida. Scientific Investigations Report 2007-5207. U.S. Geological Survey, Reston, VA.

Renken, R. A., J. Dixon, J. Koehmstedt, A. C. Lietz, S. Ishman, R. L. Marella, P. Telis, J. Rogers, and S. Memberg. 2005. Impact of Anthropogenic Development on Coastal Ground-Water Hydrology in Southeastern Florida, 1900-2000. Circular 1275, U.S. Geological Survey, Reston, VA.

Shinn, E. A., R. S. Reese, and C. D. Reich. 1994. Fate and pathways of injection-well effluent in the Florida Keys. Open-File Report Open-File Report 94-276, U.S. Geological Survey.

Spechler, R. 2001. The Relation Between Structure and Saltwater Intrusion in the Floridan Aquifer System, Northeastern Florida. In U.S. Geological Survey Karst Interest Group Proceedings, Water-Resources Investigations Report 01-4011, p. $25-29$.

Sprinkle, C. L. 1989. Geochemistry of the Floridan Aquifer System in Florida and in Parts of Georgia, South Carolina, and Alabama. Professional Paper 1403-I, U.S. Geological Survey, Washington, D.C.

Starr, R. C., T. S. Green, and L. C. Hull. 2001. Evaluation of confining layer integrity beneath the South District Wastewater treatment Plant, Miami-Dade Water and Sewer Department, Dade County, Florida. INEEL/EXT-2001-00046, Geosciences Research Department, Idaho National Engineering and Environmental Laboratory, Idaho Falls, Idaho.

Stumm, W., and J. J. Morgan. 1996. Aquatic Chemistry. John Wiley \& Sons, Inc., New York.

United States Environmental Protection Agency. 2003. Relative risk assessment of management options for treated wastewater in South Florida. Office of Water 464-M EPA 816-03-0101, USEPA, Washington, DC.

United States Environmental Protection Agency. Underground Injection Control Program. Accessed 12/22/08: http://www.epa.gov/OGWDW/uic/ 
Walsh, V. and R.M. Price. 2008. Tracing Vertical and Horizontal Migration of Injected Fresh Wastewater into a Deep Saline Aquifer using Natural Chemical Tracers. In Proceedings of the $20^{\text {th }}$ Salt Water Intrusion Meeting. Naples, Fl. 
Table 2.1 Mean values for historical time series: SDDWTP. $m b l s$ meters below land surface

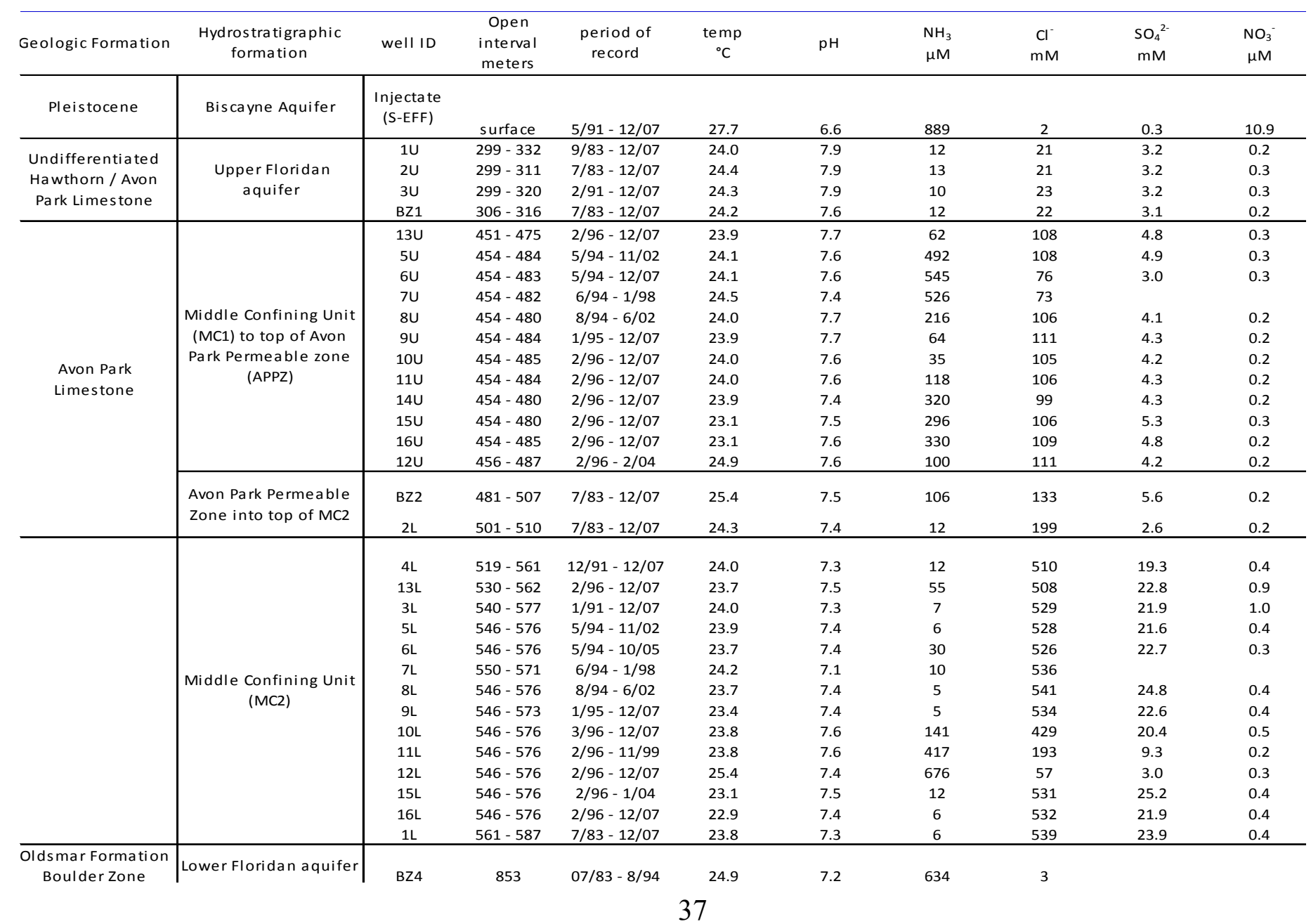


Table 2.2 Mean values for historical time series: NDWWTP. mbls below land surface

\begin{tabular}{|c|c|c|c|c|c|c|c|c|c|c|c|c|c|c|c|c|}
\hline $\begin{array}{l}\text { Geologic } \\
\text { formation }\end{array}$ & $\begin{array}{l}\text { Hydrostratigraphic } \\
\text { formation }\end{array}$ & Well ID & $\begin{array}{c}\text { open } \\
\text { interval } \\
\text { meters }\end{array}$ & $\begin{array}{l}\text { period of } \\
\text { record }\end{array}$ & temperature & $\mathrm{pH}$ & $\mathrm{NH}_{3}$ & $\mathrm{Cl}^{-}$ & $\mathrm{SO}_{4}{ }^{2-}$ & $\mathrm{NO}_{3}^{-}$ & $\begin{array}{l}\text { revised } \\
\text { period of } \\
\text { record* }\end{array}$ & temperature & $\mathrm{pH}$ & $\mathrm{NH}_{3}$ & $\mathrm{Cl}^{-}$ & $\mathrm{SO}_{4}{ }^{2-}$ \\
\hline Pleistocene & Biscayne Aquifer & Injectate (N-EFF) & $\begin{array}{l}\text { meters } \\
\text { surface }\end{array}$ & $7 / 97-12 / 07$ & $\begin{array}{ll}{ }^{\circ} \mathrm{C} \\
\end{array}$ & 6.5 & $\begin{aligned} \mu \mathrm{IV} \\
819.3\end{aligned}$ & $\frac{\mathrm{mIM}}{20.0}$ & $\frac{\mathrm{mIM}}{0.5}$ & $\frac{\mu \mathrm{M}}{37.9}$ & & ${ }^{\circ} \mathrm{C}$ & & $\mu \mathrm{M}$ & $\mathrm{mM}$ & \\
\hline \multirow{8}{*}{$\begin{array}{l}\text { Avon Park } \\
\text { Limestone } \\
\text { Eocene }\end{array}$} & \multirow{4}{*}{$\begin{array}{l}\text { Middle Confining } \\
\text { Unit (MC1) }\end{array}$} & $\mathrm{N}-1 \mathrm{U}$ & $354-385$ & $1 / 97-12 / 07$ & 23.1 & 7.6 & 18.8 & 73.7 & 3.5 & 0.2 & & & & & & \\
\hline & & $\mathrm{N}-2 \mathrm{U}$ & $351-384$ & $3 / 96-12 / 07$ & 23.0 & 7.8 & 17.7 & 66.2 & 3.6 & 2.1 & & & & & & \\
\hline & & $\mathrm{N}-3 \mathrm{U}$ & $354-379$ & $3 / 96-12 / 07$ & 22.9 & 7.8 & 17.3 & 65.8 & 3.6 & 2.0 & & & & & & \\
\hline & & $\mathrm{N}-4 \mathrm{U}$ & $354-379$ & $4 / 96-12 / 07$ & 23.1 & 7.6 & 18.1 & 68.4 & 3.5 & 0.8 & & & & & & \\
\hline & Middle Confining & $\mathrm{N}-1 \mathrm{~L}$ & $430-461$ & $4 / 96-12 / 07$ & 21.9 & 7.3 & 261.2 & 368.2 & 32.8 & 1.0 & $34 / 96-7 / 97$ & 22.4 & 7.2 & 19.3 & 461.7 & \\
\hline & Unit (MC1) to top of & $\mathrm{N}-2 \mathrm{~L}$ & $431-459$ & $3 / 96-12 / 07$ & 22.3 & 7.6 & 168.4 & 397.9 & 15.6 & 2.2 & $3 / 96-8 / 98$ & 22.9 & 7.8 & 17.7 & 455.7 & 16.6 \\
\hline & Avon Park & $\mathrm{N}-3 \mathrm{~L}$ & $430-460$ & $3 / 96-12 / 07$ & 22.2 & 7.6 & 131.4 & 409.4 & 15.8 & 1.0 & 3/96-12/98 & 23.0 & 7.7 & 19.1 & 454.8 & 14.9 \\
\hline & Permeable zone & $\mathrm{N}-4 \mathrm{~L}$ & $430-460$ & $4 / 96-12 / 07$ & 22.4 & 7.2 & 190.3 & 380.4 & 15.2 & 1.6 & $4 / 96-12 / 98$ & 22.3 & 7.5 & 23.7 & 440.5 & \\
\hline
\end{tabular}


Table 2.3 Mean field parameters and ion concentrations during the 2006-2007 sampling completed as part of this study.

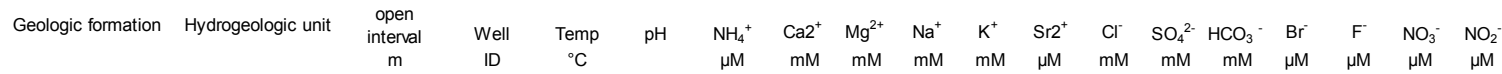

\begin{tabular}{|c|c|c|c|c|c|c|c|c|c|c|c|c|c|c|c|c|c|c|}
\hline Pleistocene & Biscayne Aquifer & surface & S-EFF & 29.0 & 6.7 & 1125 & 1 & 0 & 3 & 0 & 7 & 3 & 0 & 4 & 30 & 19 & 7 & 6 \\
\hline \multirow{4}{*}{$\begin{array}{l}\text { Undifferentiated } \\
\text { Hawthorn / Ocala } \\
\text { Limestone to Avon } \\
\text { Park Limestone }\end{array}$} & \multirow{4}{*}{$\begin{array}{l}\text { Upper Floridan } \\
\text { aquifer }\end{array}$} & $306-316$ & BZ1 & 24.2 & 7.8 & 6 & 1 & 3 & 25 & 1 & 39 & 21 & 3 & 4 & 40 & 109 & 1 & 1 \\
\hline & & $299-332$ & $1 U$ & 23.6 & 8.1 & 6 & 1 & 3 & 24 & 1 & 42 & 22 & 4 & 4 & 56 & 117 & 0 & 1 \\
\hline & & $299-320$ & $3 U$ & 24.3 & 7.9 & 6 & 1 & 3 & 25 & 1 & 48 & 28 & 4 & 4 & 54 & 119 & 4 & 1 \\
\hline & & $299-311$ & $2 U$ & 25.3 & 7.9 & 10 & 1 & 3 & 22 & 1 & 43 & 21 & 5 & 4 & 33 & 143 & 1 & 1 \\
\hline \multirow{16}{*}{$\begin{array}{l}\text { Avon Park } \\
\text { Limestone }\end{array}$} & \multirow{6}{*}{ MC1 } & $454-484$ & $9 \mathrm{U}$ & 23.8 & 7.7 & 60 & 4 & 10 & 98 & 3 & 99 & 104 & 5 & 3 & 169 & 85 & 0 & 1 \\
\hline & & $454-485$ & $10 U$ & 24.8 & 7.7 & 67 & 5 & 10 & 85 & 2 & 125 & 112 & 5 & 3 & 174 & 45 & 1 & 0 \\
\hline & & $451-475$ & $13 U$ & 24.4 & 7.7 & 143 & 4 & 10 & 88 & 3 & 113 & 109 & 5 & 4 & 200 & 119 & 2 & 1 \\
\hline & & $454-485$ & $16 \mathrm{U}$ & 23.2 & 7.7 & 439 & 4 & 9 & 94 & 3 & 75 & 102 & 5 & 5 & 250 & 135 & 1 & 1 \\
\hline & & $454-480$ & $14 U$ & 25.0 & 7.5 & 497 & 3 & 6 & 66 & 2 & 65 & 70 & 4 & 5 & 115 & 80 & 1 & 1 \\
\hline & & $454-483$ & $6 \mathrm{U}$ & 25.1 & 7.5 & 823 & 3 & 5 & 87 & 2 & 32 & 45 & 3 & 7 & 81 & 51 & 1 & 1 \\
\hline & \multirow{2}{*}{ MC1/APPZ } & $501-510$ & $2 \mathrm{~L}$ & 24.8 & 7.5 & 9 & 8 & 16 & 148 & 4 & 147 & 194 & 4 & 2 & 305 & 75 & 0 & 1 \\
\hline & & $481-507$ & BZ2 & 24.1 & 7.6 & 176 & 5 & 11 & 121 & 3 & 114 & 128 & 6 & 4 & 217 & 93 & 0 & 1 \\
\hline & \multirow{8}{*}{ MC2 } & $546-573$ & 9L & 23.1 & 7.6 & 3 & 11 & 44 & 459 & 12 & 167 & 550 & 24 & 3 & 849 & 211 & 1 & 1 \\
\hline & & $546-576$ & $16 \mathrm{~L}$ & 22.9 & 7.5 & 4 & 11 & 41 & 439 & 12 & 175 & 552 & 25 & 4 & 800 & 195 & 0 & 1 \\
\hline & & $540-577$ & $3 \mathrm{~L}$ & 24.1 & 7.5 & 4 & 10 & 43 & 440 & 12 & 159 & 522 & 23 & 3 & 834 & 233 & 5 & 1 \\
\hline & & $519-561$ & $4 \mathrm{~L}$ & 24.5 & 7.5 & 7 & 11 & 40 & 416 & 12 & 181 & 492 & 21 & 3 & 737 & 234 & 0 & 1 \\
\hline & & $530-562$ & $13 \mathrm{~L}$ & 24.2 & 7.5 & 108 & 10 & 36 & 350 & 12 & 174 & 460 & 24 & 3 & 775 & 313 & 2 & 1 \\
\hline & & $546-576$ & $10 \mathrm{~L}$ & 24.7 & 7.6 & 200 & 8 & 30 & 285 & 10 & 111 & 369 & 23 & 3 & 588 & 77 & 3 & 0 \\
\hline & & $546-576$ & $12 \mathrm{~L}$ & 28.1 & 7.6 & 765 & 3 & 6 & 49 & 2 & 36 & 54 & 4 & 5 & 87 & 35 & 2 & 0 \\
\hline & & $561-587$ & $1 \mathrm{~L}$ & 23.4 & 7.5 & 4 & 11 & 64 & 412 & 13 & 161 & 533 & 25 & 3 & 834 & 235 & 1 & 1 \\
\hline
\end{tabular}

\begin{tabular}{|c|c|c|c|c|c|c|c|c|c|c|c|c|c|c|c|c|c|c|}
\hline Pleistocene & Biscayne Aquifer & surface & $\mathrm{N}$-EFF & 26.3 & 6.5 & 505 & 2 & 2 & 20 & 1 & 6 & 16 & 1 & 3 & 36 & 10 & 38 & 49 \\
\hline \multirow{8}{*}{$\begin{array}{l}\text { Avon Park } \\
\text { Limestone }\end{array}$} & \multirow{4}{*}{ upper MC1 } & $354-385$ & N-FA-1U & 22.5 & 7.8 & 17 & 3 & 8 & 68 & 2 & 155 & 73 & 4 & 1 & 81 & 180 & 0 & 1 \\
\hline & & $351-384$ & N-FA-2U & 22.7 & 7.8 & 13 & 3 & 7 & 65 & 2 & 121 & 66 & 4 & 1 & 126 & 179 & 2 & 2 \\
\hline & & $354-379$ & N-FA-3U & 21.2 & 7.9 & 16 & 3 & 7 & 66 & 2 & 133 & 62 & 3 & 1 & 115 & 3 & 2 & 1 \\
\hline & & $354-379$ & N-FA-4U & 20.8 & 7.9 & 16 & 3 & 7 & 69 & 2 & 147 & 66 & 4 & 1 & 131 & 174 & 1 & 1 \\
\hline & \multirow{4}{*}{ lower MC1 } & $430-460$ & N-FA-3L & 19.4 & 7.5 & 215 & 9 & 37 & 423 & 11 & 216 & 380 & 17 & 3 & 651 & 537 & 1 & 2 \\
\hline & & $430-461$ & N-FA-1L & 19.9 & 7.4 & 231 & 7 & 36 & 458 & 11 & 100 & 386 & 20 & 3 & 839 & 422 & 1 & 1 \\
\hline & & $430-460$ & N-FA-4L & 19.2 & 7.4 & 264 & 9 & 37 & 421 & 11 & 223 & 371 & 19 & 3 & 695 & 463 & 2 & 1 \\
\hline & & $431-459$ & N-FA-2L & 20.1 & 7.4 & 295 & 8 & 39 & 431 & 12 & 125 & 383 & 22 & 3 & 748 & 486 & 2 & 1 \\
\hline
\end{tabular}


Table 2.4 Historical ambient Floridan Aquifer water quality data

\begin{tabular}{|c|c|c|c|c|c|c|c|c|c|c|c|}
\hline Parameter & unit & $\begin{array}{c}1 U \\
299-332 m \\
\end{array}$ & $\begin{array}{c}{W W F^{a}} \\
260-305 \mathrm{~m}\end{array}$ & $\begin{array}{c}W W F^{b} \\
260-308 \mathrm{~m}\end{array}$ & $\begin{array}{r}\text { FPL PW- } 3^{\mathrm{c}} \\
314-380 \mathrm{~m}\end{array}$ & $\begin{array}{l}\text { FPL Test Well } \\
340-410 \mathrm{~m}\end{array}$ & $\begin{array}{c}9 U \\
454-484 m \\
\end{array}$ & $\begin{array}{l}\text { FPL Test Well }^{d} \\
456-517 \mathrm{~m}\end{array}$ & $\begin{array}{c}2 L \\
501-510 \mathrm{~m} \\
\end{array}$ & $\begin{array}{c}3 L \\
530-562 \mathrm{~m} \\
\end{array}$ & $\begin{array}{c}\text { FPL Test Well } \\
639-701 \mathrm{~m} \\
\end{array}$ \\
\hline$\overline{\mathrm{pH}}$ & & 7.9 & 8.0 & 7.4 & 7.5 & 7.7 & 7.7 & 7.5 & 7.5 & 7.5 & 7.0 \\
\hline $\mathrm{HCO}_{3}^{-}$ & $\mathrm{mM}$ & 0.0 & & & & 3.2 & 2.7 & 3.3 & 2.1 & 3.0 & 2.6 \\
\hline $\mathrm{Ca}^{2+}$ & $\mathrm{mM}$ & 1.3 & & & 1.7 & 3.7 & 4.3 & 6.7 & 7.8 & 10.3 & 19.6 \\
\hline $\mathrm{Mg}^{2+}$ & $\mathrm{mM}$ & 2.7 & & & 2.8 & 7.3 & 10.1 & 15.5 & 16.0 & 43.4 & 55.5 \\
\hline $\mathrm{Na}^{+}$ & $\mathrm{mM}$ & 24.7 & & & 22.2 & 74.6 & 98.3 & 158.2 & 148.2 & 438.2 & 487.2 \\
\hline $\mathrm{K}^{+}$ & $\mathrm{mM}$ & 0.8 & & & 0.8 & 2.0 & 2.6 & 3.8 & 3.6 & 11.8 & 9.7 \\
\hline $\mathrm{Cl}^{-}$ & $\mathrm{mM}$ & 22.3 & & 70.5 & 27.1 & 82.1 & 104.3 & 179.4 & 193.9 & 521.6 & 592.3 \\
\hline $\mathrm{SO}_{4}^{2-}$ & $\mathrm{mM}$ & 4.1 & 7.5 & 6.9 & 0.3 & 6.9 & 4.7 & 13.7 & 4.2 & 22.6 & 30.7 \\
\hline $\mathrm{NO}_{3}^{-}$ & $\mu \mathrm{M}$ & 0.3 & 0.8 & 0.2 & & 0.2 & 0.2 & 0.3 & 0.2 & 4.8 & 0.2 \\
\hline $\mathrm{F}^{-}$ & $\mathrm{mM}$ & 0.1 & & 0.1 & & 0.1 & 0.1 & 0.1 & 0.1 & 0.2 & 0.1 \\
\hline $\mathrm{Si}^{\circ}$ & $\mathrm{mM}$ & 0.5 & & & & 0.4 & 0.2 & 0.5 & 0.3 & 0.3 & 0.2 \\
\hline $\mathrm{Sr}^{2+}$ & $\mu \mathrm{M}$ & 41.9 & & & & 77.6 & 98.2 & 184.9 & 147.2 & 158.6 & \\
\hline Total P & $\mu \mathrm{M}$ & 3.2 & 7.1 & & & & 6.5 & & 6.5 & 3.2 & \\
\hline $\mathrm{NH}_{4}^{+}$ & $\mu \mathrm{M}$ & 5.5 & 7.2 & & & & 61.0 & & 11.1 & 5.5 & \\
\hline $\mathrm{NH}_{3}^{\circ}$ & $\mu \mathrm{M}$ & & 0.8 & 29.4 & 12.3 & & & & & & \\
\hline
\end{tabular}

Italized data were data collected for this study during 2006 - 2007 for wells at the south site. (a) data from Muniz Group 1995; (b) data from CH2MHill, 1998; (c)Florida Partners 2006; (d) data from Dames and Moore, 1975. 


\section{$2.11 \quad$ Figures}

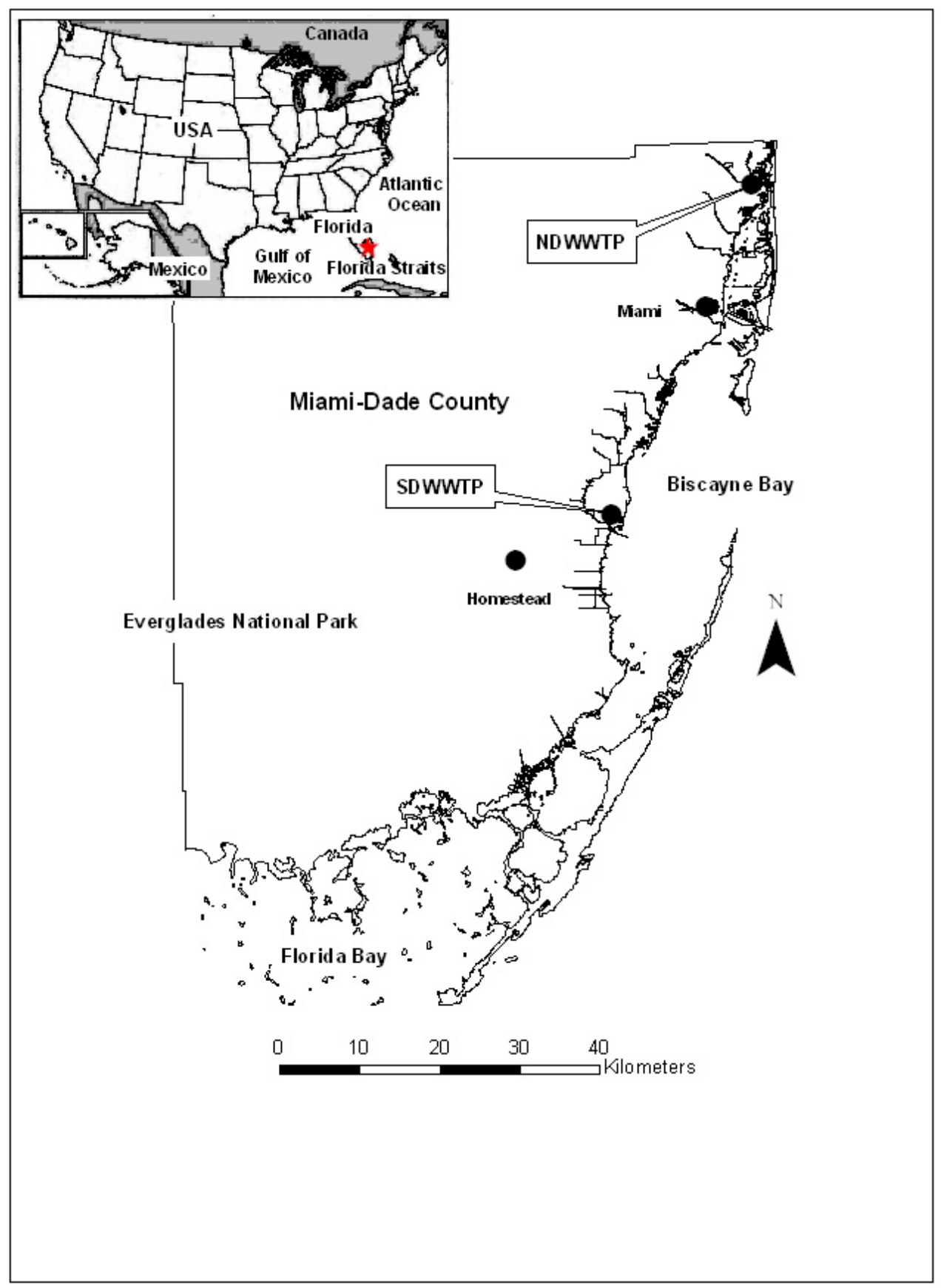

Figure 2.1 Location of the NDWWTP and the SDWWTP study sites. 


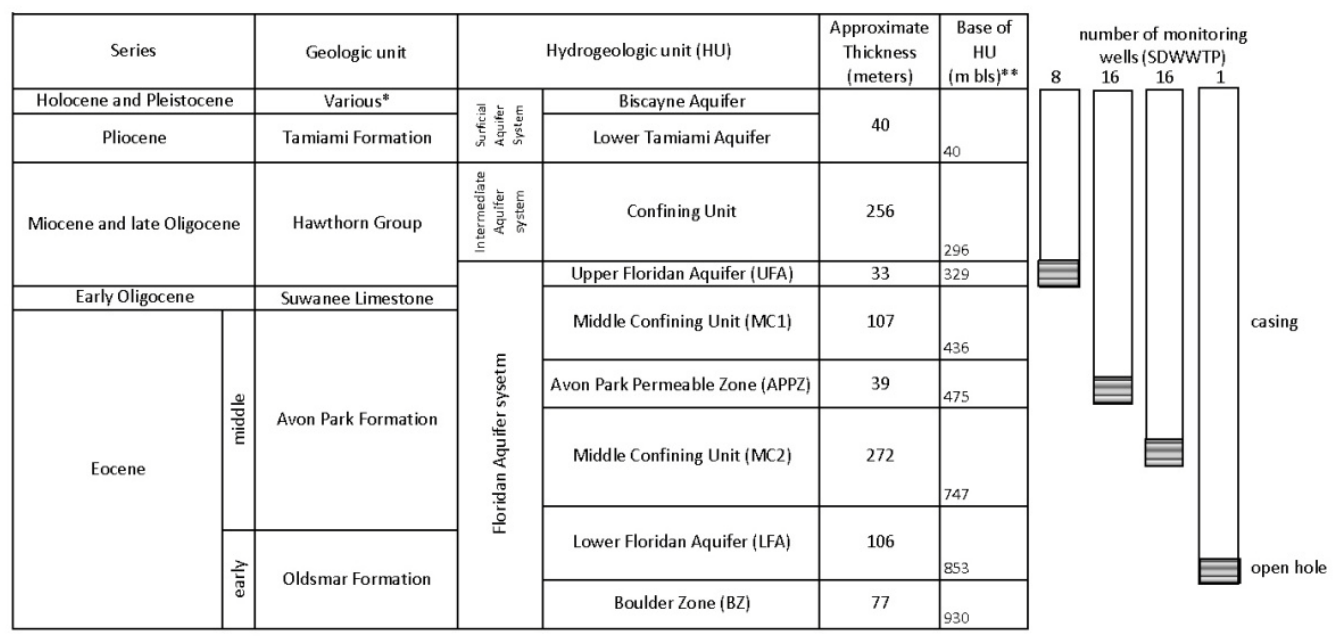

* includes Miami Limestone, Fort Thompson Formation, Anastatia Formation, Key Largo Limestone ** meters below land surface

Figure 2.2 Geologic and hydrogeologic framework of NDWWTP and the SDWWTP, modified from Reese and Richardson, 2008. Well diagram on the right shows the number of wells open to the indicated hydrogeologic unit used for this study. 


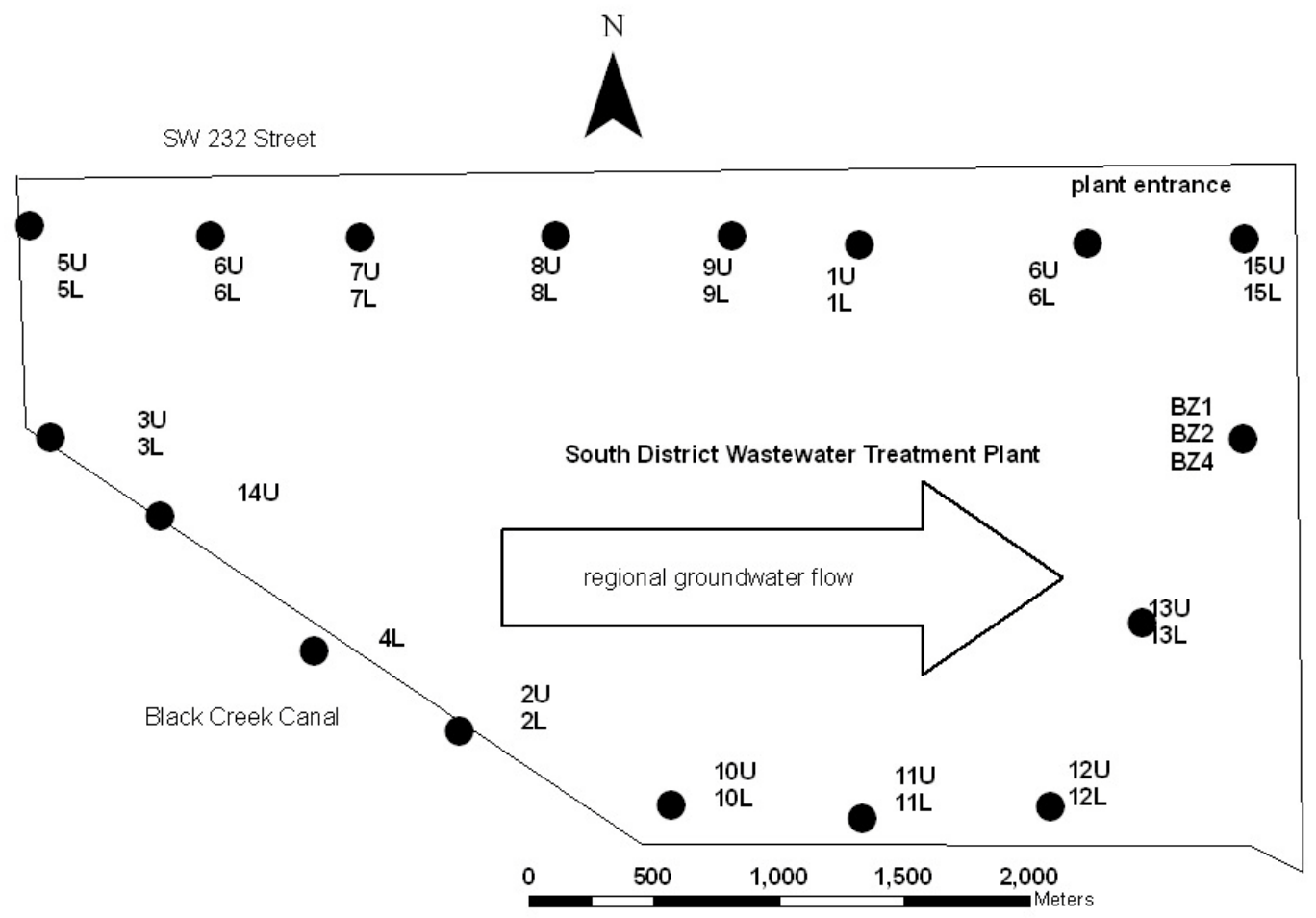

Figure 2.3 Well locations at the SDWWTP. 


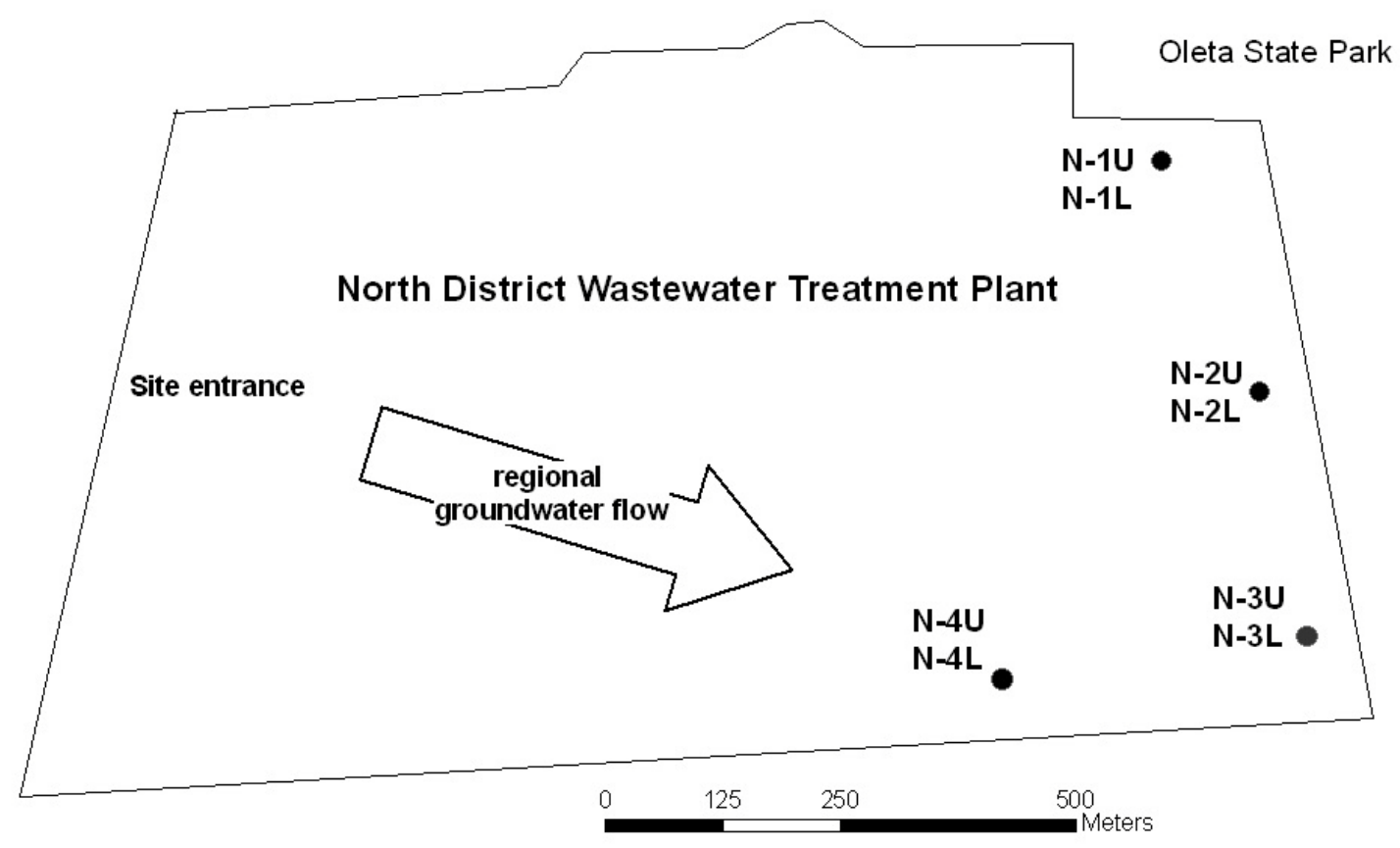

Figure 2.4 Well locations at the NDWWTP. 


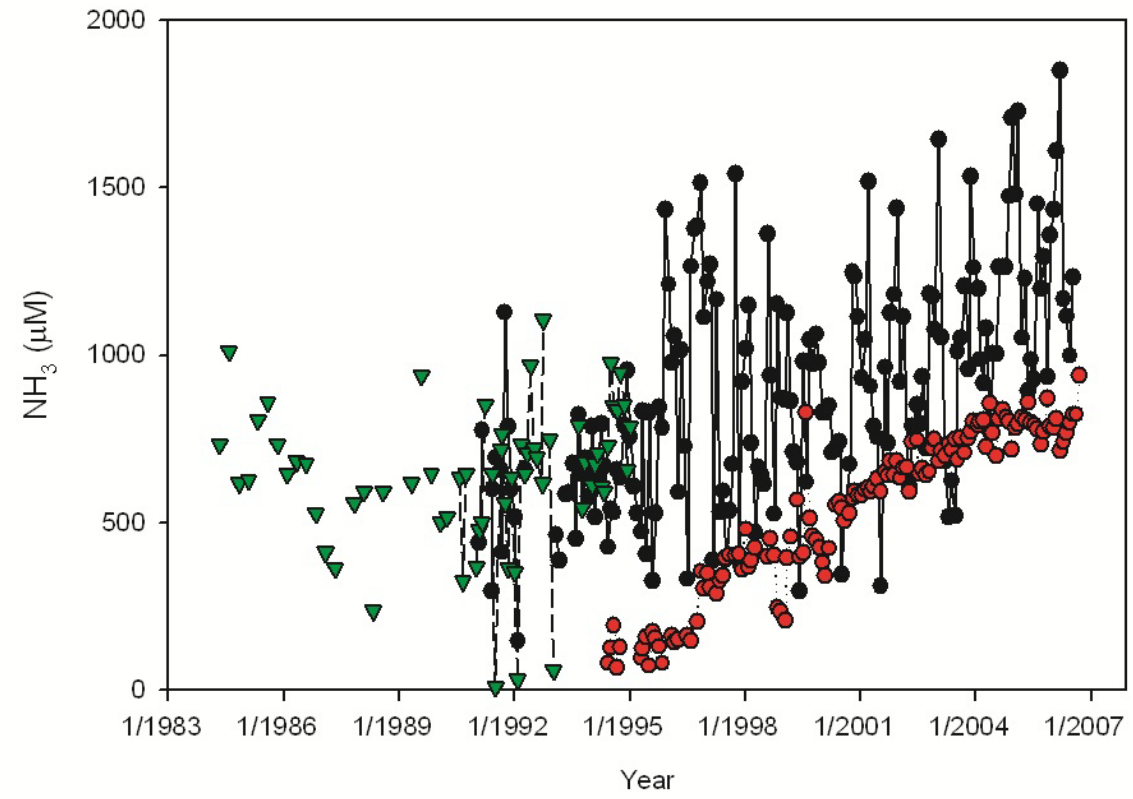

Figure 2.5 Time series $\mathrm{NH}_{3}$ data from the injectate (black circle), BZ-4 (green triangle) and well 6U (red circle) at the SDWWTP site. The apparent seasonal variation observed in the injectate is a result of increased flows during the wet season and storm events. The increasing trends with time correlate to increased injection over time due to growth in population in Miami-Dade County. 

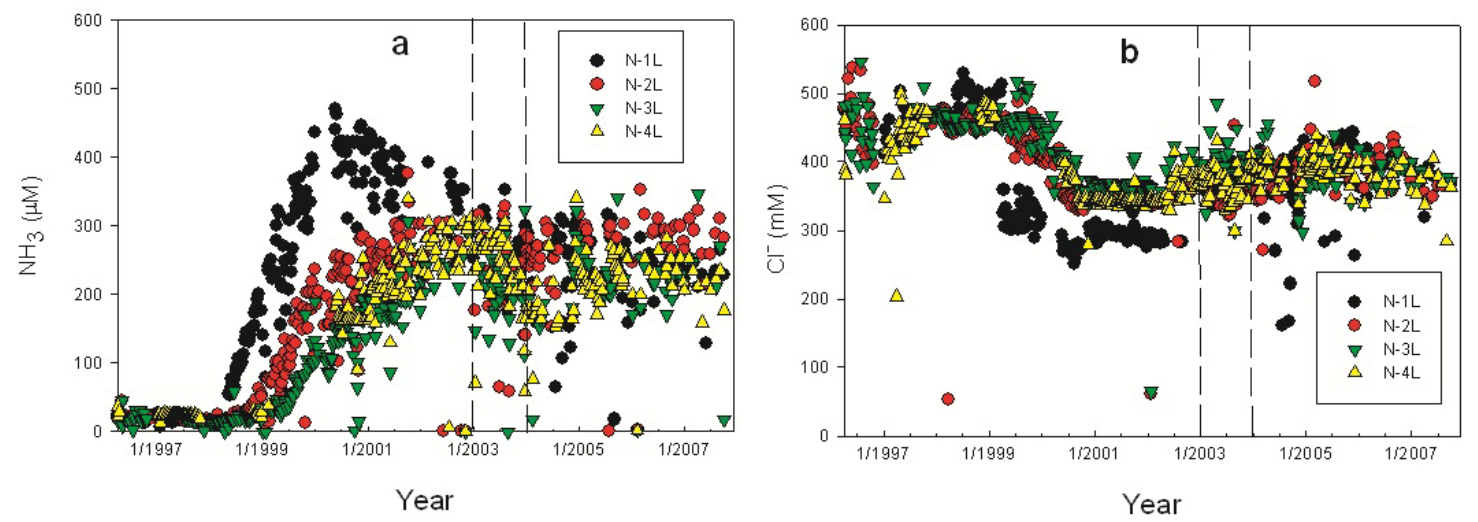

Figure 2.6 Graph a shows the $\mathrm{NH}_{3}$ data time series for the wells in the APPZ interval at the NDWWTP. The dashed lines indicate the purging time from 2003 through $2004 . \mathrm{NH}_{3}$ concentrations are observed to increase in well N-1L similar to contaminant breakthrough contaminant breakthrough curves. Well N-1L was the closest well to the uncased injection well when injectate backflowed into the APPZ. NH3 concentrations for wells N-2L, N-3L, and N-4L appear to be similar and show a similar increase after 1999. Variability is seen in the data after 2003. Graph b shows $\mathrm{Cl}^{-}$concentrations in well N-1L clustered at approximately $300 \mathrm{mM}$, and an abrupt decrease to less than $300 \mathrm{mM}$ is seen. $\mathrm{Cl}^{-}$ concentrations in wells N-2L, N-3L, and N-4L are very similar, and show a decrease in concentrations after 1999 until 2000, when concentrations appear to stabilize. $\mathrm{Cl}^{-}$ concentrations start to increase slightly and become variable after 2003. All four wells show similar concentrations of both $\mathrm{NH}_{3}$ and $\mathrm{Cl}^{--}$after 2004 . 

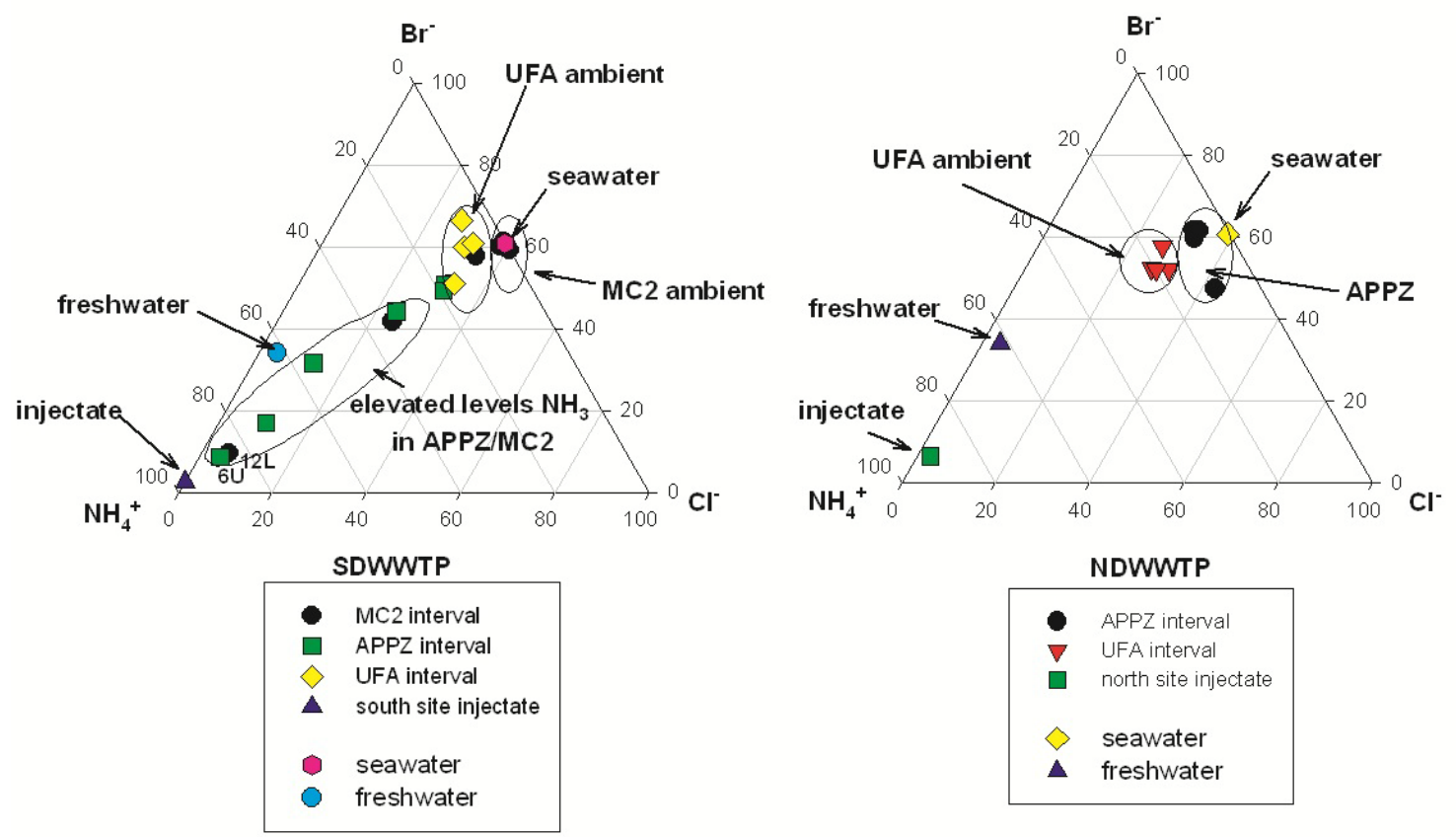

Figure 2.7 Ternary diagrams for the NDWWTP and the SDWWTP. $\mathrm{NH}_{4}^{+}, \mathrm{Cl}^{-}$, and $\mathrm{Br}^{-}$ data collected from 2006 - 2007 were normalized to $100 \%$. Seawater and freshwater values (Hem, 1985) were plotted. Ambient water was grouped at the SDWWTP for the MC2 and UFA intervals. Ambient MC2 data plot directly with seawater. UFA ambient plots towards freshwater, reflecting the fresher water quality in the UFA. The injectate data plot at the $\mathrm{NH}_{4}{ }^{+}$end point, indicating the freshwater quality but high $\mathrm{NH}_{4}{ }^{+}$ concentration of the injectate. Well data from the APPZ and MC2 intervals that have $\mathrm{NH}_{4}{ }^{+}$concentrations above ambient levels plot in a line towards the injectate end point, with data from wells $6 \mathrm{U}$ and $12 \mathrm{~L}$ plotting very close the $\mathrm{NH}_{4}{ }^{+}$end point. Data from the SDWWTP plot into distinct groups based on depth in the aquifer, but no line towards the injectate end point is seen. 

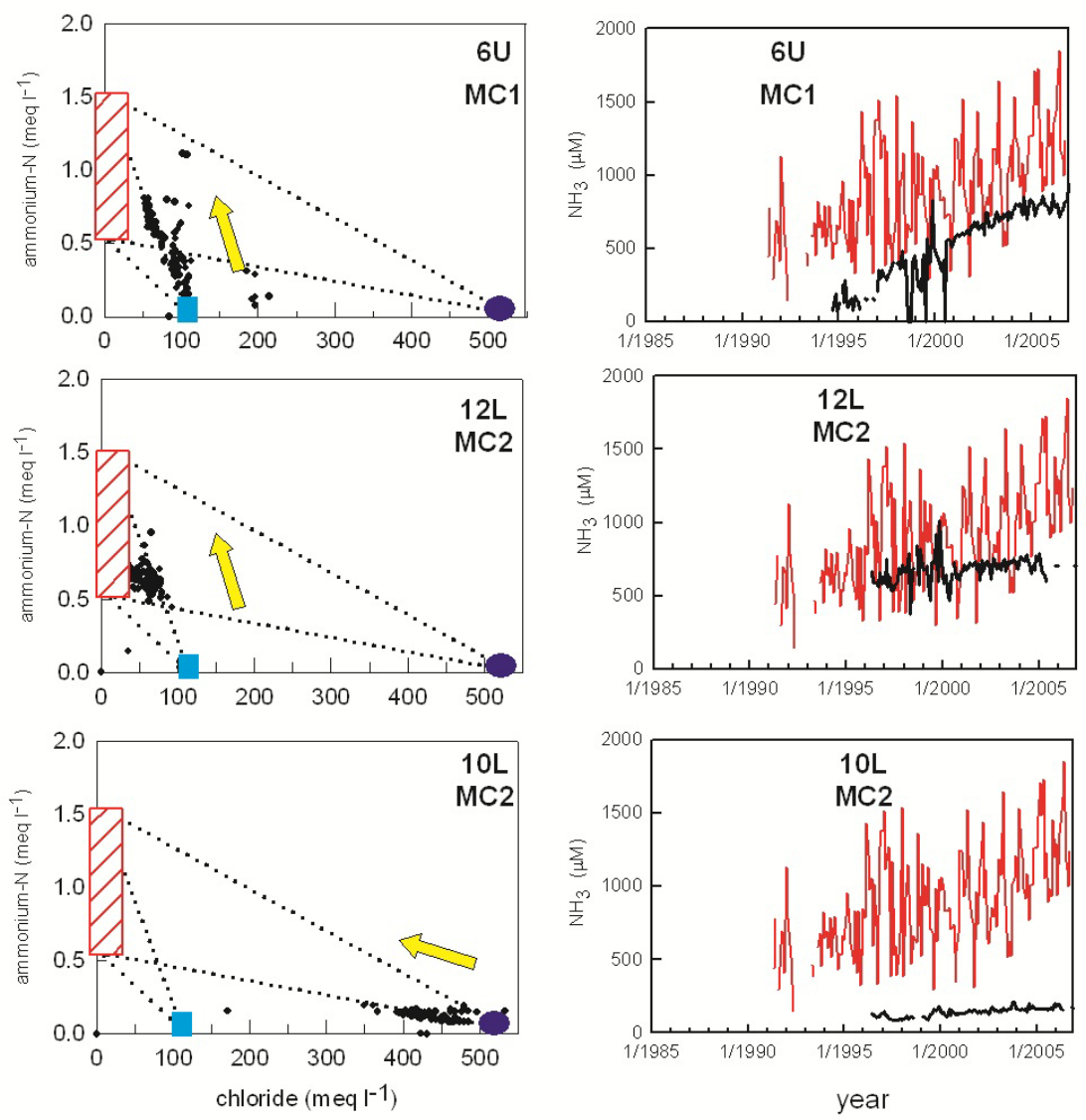

Figure 2.8 Graphs on the left are $\mathrm{NH}_{3} / \mathrm{Cl}^{-}$mixing end member models for the APPZ and MC2 intervals at the SDWWTP. 6U, 12L and 10L are well identification codes. Arrows indicate increase in time. Hatched red rectangle is injected freshwater end member, indicating the seasonal range in concentrations. Cyan square is the APPZ brackish water ambient water end member; purple circle is the MC2 saline water end member. Graphs on the right are $\mathrm{NH}_{3}$ concentrations over time. Solid black lines are concentrations from each well site; red line is injected freshwater concentrations. For wells $6 \mathrm{U}$ and $12 \mathrm{~L}$ the data plot towards the injectate end member. Little influence is seen in well $6 \mathrm{U}$ from the saline MC2 end member. Well 10L shows a different evolution of water quality, with data plotting at the saline MC2 end member and slowly plotting towards the lower end of the injectate end member. 

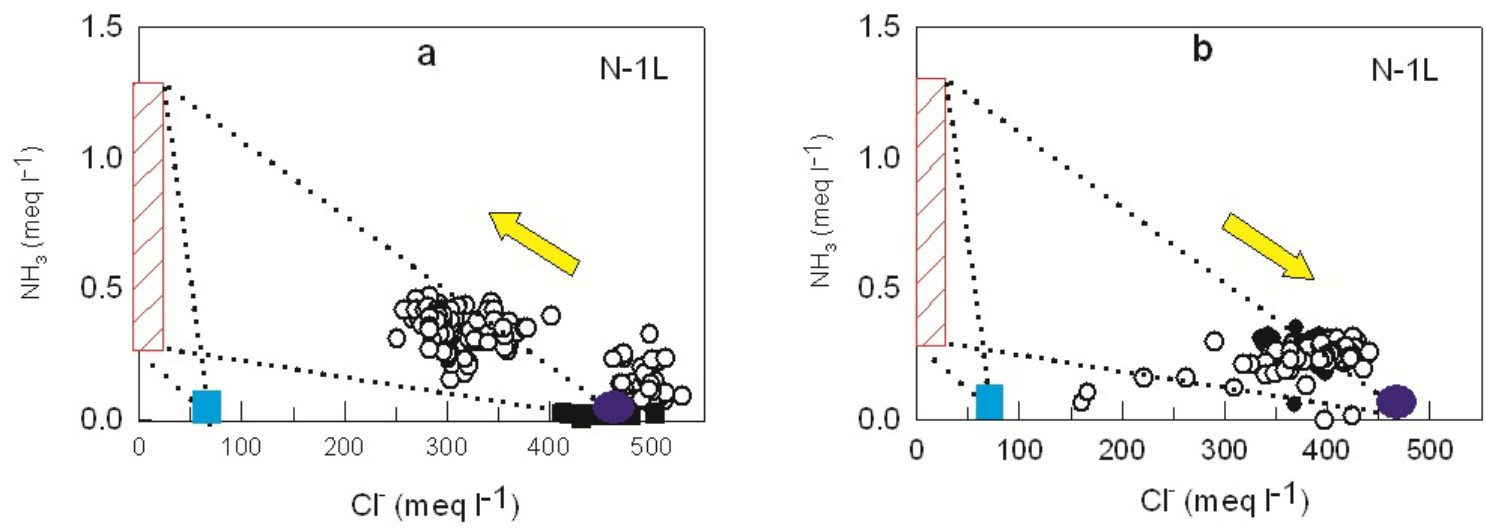

Figure 2.9 Graph a is the $\mathrm{NH}_{3} / \mathrm{Cl}^{-}$mixing end member model for the APPZ at the NDWWTP for pre-purge data (prior to 2003) for well N-2L. Arrows indicate increase in time. Hatched red rectangle is injected freshwater end member, indicating the seasonal range in concentrations. Cyan square is the UFA brackish water ambient water end member; purple circle is the APPZ saline water end member. The data plot in separate groupings, with the earliest time series plotting around the APPZ saline end member. The second data cluster plot towards the injectate end member, but no evolution towards the injectate end member is seen as was seen for wells $6 \mathrm{U}$ and $12 \mathrm{~L}$ at the SDWWTP. Graph b is the post-purge data plotted for well N-1L. Data plot with time back towards the APPZ saline end member. 


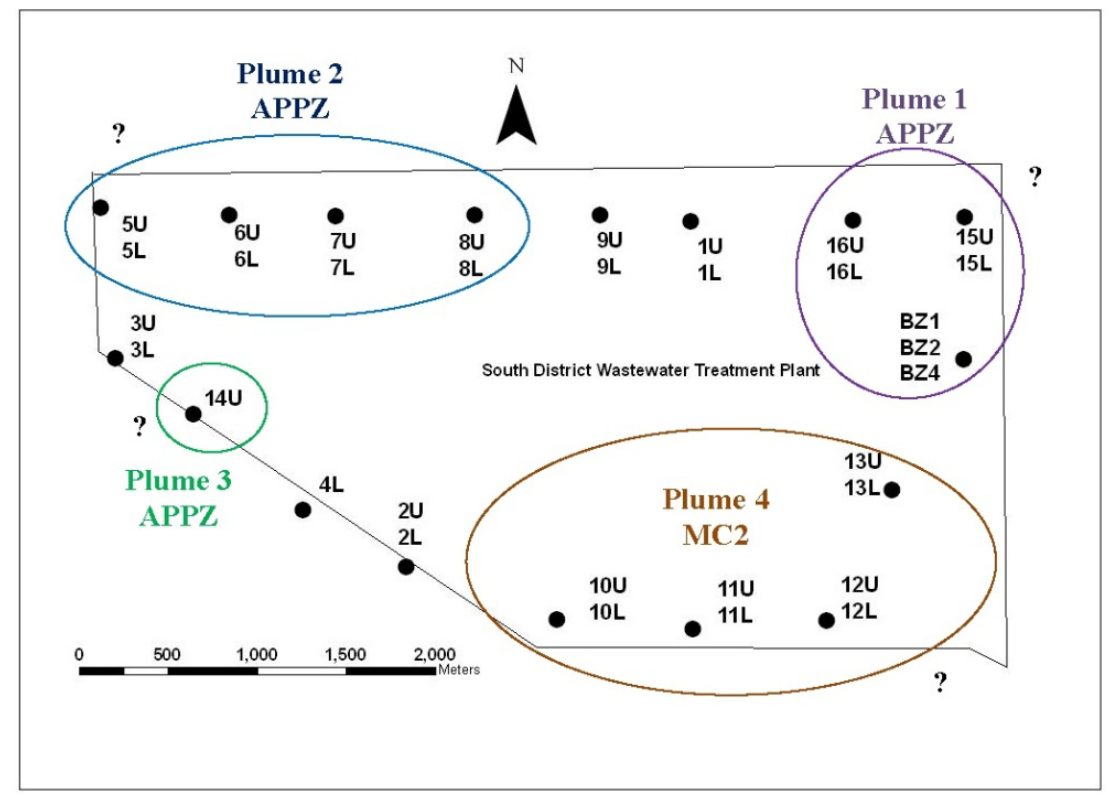

Figure 2.10 Location of injectate plumes and their depth interval at the SDWWTP. The source of the plume centered on the BZ well clusters (plume 1) was plugged in 1995. The plumes 2, 3, and 4 are the result of continuing rapid vertical pathways up from the Boulder Zone. The extent of the plumes off site is not known, as indicated by the question marks, however, based on data collected from the site, approximate extent of the plumes on the site can be inferred. The plume in the MC2 is limited to the southeast of the site. The plume located in the northwest of the site is located in the APPZ, and appears to have bypassed the MC2. The plume from the BZ well cluster appears to be limited to the east of the site. It is unknown the extent of the plume at $14 \mathrm{U}$ on site, as there are no wells that monitor the same aquifer interval in the vicinity of $14 \mathrm{U}$. 


\section{CHAPTER 3 THE FATE AND TRANSPORT OF AMMONIUM FROM FRESH}

WASTEWATER INJECTED INTO A DEEP SALINE AQUIFER AS DETERMINED FROM NATURAL ISOTOPES AND DISSOLVED GASES

\subsection{Introduction}

Karst aquifers have traditionally been used for sources of drinking water, however in the last several decades they have also been increasingly used for disposal of wastewater. Miami-Dade Water and Sewer Department (MDWASD) has been injecting treated domestic wastewater (injectate) into a highly transmissive carbonate formation known as the Boulder Zone (BZ) via injection wells since the early 1980's at two locations (Figure 3.1) (MDWASD, 1995; MDWASD 2005). In south Florida, the BZ is a saline, nonpotable aquifer, located at a depth of approximately 900 meters (m) below land surface (bls), in the lower portion of the Floridan Aquifer System (FAS) (Meyer, 1989a; Meyer, 1989b; Reese, 1994). The FAS is divided into 3 portions, the Upper Floridan Aquifer (UFA), the Middle Confining Units, and the Lower Floridan Aquifer (Figure 3.2). Water quality in the UFA is slightly brackish and is increasingly used in south Florida as a municipal water supply source. In the $1990 \mathrm{~s}$, concentrations of ammonium $\left(\mathrm{NH}_{4}{ }^{+}\right)$ above ambient concentrations were detected in groundwater monitoring wells located in the Middle Confining Units of the FAS at two MDWASD injection sites (the North District Waste Water Treatment Plant (ND) and the South District Waste Water Treatment Plant (SD)). The elevated concentrations of $\mathrm{NH}_{4}{ }^{+}$were interpreted as evidence for upward migration of the injectate above the BZ, posing a possible risk to drinking water supplies (Starr et al., 2001). Being freshwater with a slightly higher temperature 
than the ambient groundwater in the BZ, the injectate is buoyant and will naturally migrate to higher levels in the aquifer, (Walsh and Price, 2010).

Initial placement of the bottom of the casing of the injection wells was below the base of the Middle Confining units overlying the BZ, with the intention of these confining layers prohibiting upward fluid migration. Various hypotheses have been proposed to account for the migration of injectate above the BZ, including a lack of aquifer confinement due to natural faults and fractures in the overlying confining layer, and/or improperly constructed or maintained injection wells (MDWASD, 1995; Rust Environmental, 1998; Maliva, et al., 2007; McNeill, 2000; MDWASD, 2005; Starr et al., 2001; King et al., 2009; Dausman, et al., 2010; Walsh and Price, 2010). Early attempts of discovering the cause of the upward migration of injectate were conducted by MDWASD, and resulted in the conclusion that improper construction of the injection wells was the mostly likely cause (Rust Environmental, 1998; MDWASD, 2005). A variable-density, numerical, groundwater flow model was completed to test various hypotheses for the upward migration of the injectate at the SD site. Hypotheses considered in the modeling exercise were related to either physical problems with the injection wells themselves (i.e. improper construction or the development of holes in the well casings) or to uncertainties in the geologic properties (natural faults, fractures or heterogeneity) of the confining layer above the Boulder Zone (Dausman et al., 2010). The model results suggested that improper construction of the injection wells were more likely responsible for the upward migration of the injectate, but in some instances natural hetereogeneity in the confining layer may also have played a role. Walsh and Price (2010) analyzed geochemical data 
from both injection sites and identified multiple plumes of injectate in the Middle Confining Units of the FAS above the BZ, but not in the overlying Upper Floridan Aquifer. Four plumes were identified at the SD, while one plume was identified at the North District. Once in the Middle Confining Units, the injectate was transported horizontally with the general direction of groundwater flow. In the first study, major ion and nutrient data were used to identify the presence and possible upward migration pathways of the leachate plumes (Walsh and Price, 2010). The objective of this investigation is to use geochemical tracers, specifically the stable isotopes of nitrogen, oxygen, and hydrogen, as well as tritium, and dissolved gases to further the define the timing and formation of the leachate plumes as well as to describe the fate and transport of $\mathrm{NH}_{4}{ }^{+}$in the Floridan Aquifer System.

\subsection{Geology and Hydrogeology}

South Florida is underlain by two aquifer systems, the Surficial Aquifer System (SAS), and the FAS, which are separated by a thick confining unit. The hydrogeology of the SAS and FAS in south Florida were described in great detail by Fish and Stewart (1991), and by Reese (1994) and Reese and Richardson (2008). The SAS is an unconfined carbonate sequence of Pleistocene age that is the source of potable water for south Florida. Underlying the SAS is a group of impermeable sediments known as the Hawthorn group (Figure 3.2). The Hawthorn group is composed predominantly of clayrich quartz sands and mudstones of Miocene age, and acts as a confining layer between the SAS and the Floridan Aquifer System. In south Florida the FAS has been separated into four major hydrogeologic zones. The Upper Floridan aquifer (UFA) consists of 
highly permeable zones (flow zones) interlayered with thicker, lower permeable zones. The Middle Confining Units MC1 and MC2 underlies the UFA, with the two units separated by the Avon Park Permeable Zone (APPZ; Figure 3.2). The Lower Floridan aquifer (LFA) is a thick sequence of permeable layers separated by thick semiconfining units (Miller, 1986). Most of the permeable layers are several meters thin, with the exception of the very transmissive BZ located at the bottom of the LFA, which is approximately $100 \mathrm{~m}$ thick. The base of the FAS in south Florida is approximately $930 \mathrm{~m}$ bls (Meyer, 1989a) and marked by the massive impermeable anhydrite beds of the Cedar Keys Formation (Miller, 1986). The UFA in south Florida is used for groundwater withdrawals for public supply and also for Aquifer Storage and Recovery (ASR). The BZ is used for the disposal of treated domestic wastewater and industrial wastewater.

Groundwater in the FAS originates mainly from two sources: precipitation and seawater. The FAS outcrops in central Florida, where it is recharged via precipitation. In south Florida, the top of the FAS lies approximately $300 \mathrm{~m}$ below land surface. Recharge of the UFA and the APPZ is described as meteoric water during the last glacial period (LGP) when sea levels were over $100 \mathrm{~m}$ lower than present (Reese, 1994; Morrissey et al., 2010). Estimates of groundwater age of the UFA and Middle Confining units are greater than 30,000 years old using by carbon-14 dating techniques (Hanshaw et al., 1965; Plummer, 1977; Meyer, 1989a). The long groundwater travel time from central to south Florida, and the resultant long contact time of the groundwater with the aquifer matrix rock results in brackish water quality of the UFA in south Florida. The LFA and the BZ outcrop along the Florida Straits, and water quality is saline, similar to ocean water, as 
these zones are recharged with Holocene-aged ocean water from the Straits of Florida (Kohout, 1965; Meyer, 1989a; Morrissey et al., 2010).

\subsection{Site Descriptions}

Both of the Miami-Dade wastewater treatment/injection sites lie in close proximity to Biscayne Bay (Figure 3.1). The SD, in operation since 1983, consists of seventeen (17) deep injection wells that dispose of approximately 352 million liters per day, and 17 dual zoned monitoring wells (MW) used for water quality in the formations overlying the Boulder Zone (Figure 3.3). Originally, the dual zoned MWs were constructed to be able to monitor two permeable zones of the FAS individually from one well location. However, many of the MWs have corroded casings which have allowed a hydraulic connection between the different zones in the borehole casings, therefore only MWs that were determined to be intact were used for the current study (see Walsh and Price (2010) for complete well descriptions and history). The MWs at the SD were used to assess the water quality of the UFA (299 to $320 \mathrm{~m}$ bls), MC1 (454 to $485 \mathrm{~m}$ bls), lower MC1/APPZ (481 - $510 \mathrm{~m}$ bls) and MC2 (546 to $576 \mathrm{~m}$ bls) zones. The ND consists of four deep injection wells that dispose of approximately 151 million liters per day (Figure 3.4). The MWs at the ND are open to the UFA (354 to $379 \mathrm{~m}$ bls) and lower MC1/APPZ (354 to $379 \mathrm{~m}$ bls). The lower MWs at both sites are designed to monitor water quality below underground sources of drinking water (USDW, as defined by federal code as aquifers with water quality below $10,000 \mathrm{mg} / \mathrm{L}$ total dissolved solids), and to act as sentinel wells in the event of upward fluid migration. The upper monitoring wells monitor water quality above the underground source of drinking water. 


\subsection{Background on Isotopes and Dissolved Gases}

\subsubsection{Nitrogen Stable Isotopes}

The oxidation of $\mathrm{NH}_{4}^{+}$to nitrate $\left(\mathrm{NO}_{3}^{-}\right)$in the presence of oxygen $\left(\mathrm{O}_{2}\right)$, is known as nitrification. The FAS as a whole is considered to be in equilibrium with respect to nitrogen $(\mathrm{N})$, as there are no known mineral sources of $\mathrm{N}$ within the FAS and total $\mathrm{N}$ concentrations are similar in both recharge and discharge areas (Sprinkle, 1989). Despite the nearly consistent concentrations of total $\mathrm{N}$ throughout the FAS, there is a decrease in the oxidized $\mathrm{N}$ species and an increase in the reduced $\mathrm{N}$ species from areas of recharge to discharge. Ambient N concentrations for the FAS in south Florida are very low, with reported concentrations of less than $15 \mu \mathrm{mols} / \mathrm{L}$ for $\mathrm{NH}_{4}^{+}$and less than $1 \mu \mathrm{mols} / \mathrm{L}$ for nitrate (Meyer, 1989a; Walsh and Price, 2010). At the Miami-Dade study sites, $\mathrm{N}$ has been introduced to the FAS as a result of the injectate, with $\mathrm{N}$ species present in injectate primarily as $\mathrm{NH}_{4}^{+}$at concentrations of greater than $25 \mathrm{mmol}$ per liter (Walsh and Price, 2010).

Nitrogen consists of two stable isotopes, ${ }^{14} \mathrm{~N}$ and ${ }^{15} \mathrm{~N}$. The nitrogen isotopic value $\left(\delta^{15} \mathrm{~N}\right)$ is reported relative to atmospheric air $\left(\delta^{15} \mathrm{~N}_{\mathrm{N} 2}=0 \%\right.$ o AIR $)$. Values are reported in part per thousand delta $(\delta)$ units according to the equation:

$$
\delta^{15} \mathrm{~N}=\left[\frac{{ }^{15} \mathrm{~N} /{ }^{14} \mathrm{~N}_{(\text {sample) }}}{{ }^{15} \mathrm{~N} /{ }^{14} \mathrm{~N}_{(\text {AIR })}}-1\right] \times 1000
$$


Animal wastes and sewage are characterized by enriched $\delta^{15} \mathrm{~N}$ values (Clark and Fritz, 1997) in the range of $+8-+12$ per mil. Use of $\delta^{15} \mathrm{~N}$ values for determining domestic sewage contamination is well documented in the literature in a variety of aquifers (Lapointe, et al., 1990; Böhlke and Denver, 1995; Griggs et al., 2003; Fukuda et al., 2004). In south Florida, research has been conducted on the fate and transport of effluent waste in the Florida Keys, primarily from septic tanks and small wastewater treatment plants (Shinn et al., 1994; Corbett, et al., 2000; Griggs et al., 2003), and in central Florida with regards to agricultural nitrate contamination (Tihansky and Sacks, 1997). Studies in the Florida Keys focused mainly on $\delta^{15} \mathrm{~N}$ in nitrates, (less in ammonium), and found enriched values of $\delta^{15} \mathrm{~N}$ of $\geq+7 \%$ (Griggs et al., 2003; Böhlke et al., 2003). Studies of $\mathrm{NH}_{4}^{+}$ammonium in groundwater near injection of treated sewage effluent in the Keys found $\delta^{15} \mathrm{~N}$ values of +9 to +12 per mil (Böhlke et al., 2003).

As a result of nitrification, $\mathrm{NH}_{4}^{+}$often reacts non-conservatively as it is transported in groundwater away from recharge areas. Ambient FAS groundwater at the study sites is anoxic. The injectate is also anoxic as a result of the removal of $\mathrm{O}_{2}$ in the treatment process prior to injection, and is also very low in nitrate. Concentrations of $\mathrm{NO}_{3}^{-}$are very low in the monitored zones, including the wells that have elevated $\mathrm{NH}_{4}^{+}$concentrations (Walsh and Price, 2010).

\subsubsection{Background on Stable Isotopes of Oxygen and Hydrogen} Isotope values for $\delta^{18} \mathrm{O}$ and $\delta^{2} \mathrm{H}$ are useful in interpreting the source of waters in aquifers. Isotope values are compared to the global meteoric line (GML), which defines 
the relationship between $\delta{ }^{18} \mathrm{O}$ and $\delta^{2} \mathrm{H}$ in precipitation from around the world (Craig, 1961):

$\delta^{2} \mathrm{H}=8 \delta^{18} \mathrm{O}+10 \%$

Meteoric water in continental environments typically have a distinguishable isotopic signature $\left(\delta^{18} \mathrm{O}\right.$ and $\left.\delta^{2} \mathrm{H}\right)$ that is more negative than seawater (Clark and Fritz, 1997). Groundwaters that plot to the right of the GML indicate either waters that have undergone evaporation prior to recharge or groundwaters that have undergone geothermal heating. The stable isotopes of ${ }^{18} \mathrm{O}$ and ${ }^{2} \mathrm{H}$ are reported to the water standard, Vienna Standard Mean Ocean Water (VSMOW) which has a defined isotopic value of 0 \% for both $\delta^{18} \mathrm{O}$ and $\delta^{2} \mathrm{H}$. Most natural seawater isotope values are close to 0 per mil. As with the nitrogen isotopic value, both $\delta^{18} \mathrm{O}$ and $\delta^{2} \mathrm{H}$ values are reported in part per thousand delta $(\delta)$ units according to the equations:

$$
\begin{aligned}
& \delta^{18} \mathrm{O}=\left[\frac{{ }^{18} \mathrm{O} /{ }^{16} \mathrm{O}_{\text {(sample) }}}{{ }^{18} \mathrm{O} /{ }^{16} \mathrm{O}_{\text {(vsmow) }}}-1\right] \times 1000 \\
& \delta^{2} \mathrm{H}=\left[\frac{{ }^{2} \mathrm{H} /{ }^{1} \mathrm{H}_{\text {(sample) }}}{{ }^{2} \mathrm{H} /{ }^{1} \mathrm{H}_{\text {(vsmow) }}}-1\right] \times 1000
\end{aligned}
$$

Isotope hydrology of south Florida has been extensively studied in the SAS (Swart et al., 1989; Price, 2001; Meyers et al., 1993; Price and Swart 2006; Price et al., 2008), and in the Floridan Aquifer in central and west Florida (Swancar and Hutchinson, 1992; Sacks, 1995; Katz et al., 1997; Rectenwald, 2000; Morrissey et al., 2010). Reported weighted 
mean values of $\delta^{18} \mathrm{O}$ and $\delta^{2} \mathrm{H}$ in south Florida for precipitation were in the range of $-3.64 \%$ to $-2.67 \%$ for $\delta^{18} \mathrm{O}$ and -for $\delta^{2} \mathrm{H}$, and $-20.2 \%$ to $7.6 \%$ for $\delta^{2} \mathrm{H}$ (Price et al., 2008; Swart et al., 1989)), with a spatial variation. Values of $\delta^{18} \mathrm{O}$ and $\delta^{2} \mathrm{H}$ for an artesian FAS well in south Florida was reported in the range of $-2.1 \%$ to $-1.6 \%$ for $\delta^{18} \mathrm{O}$, and $-11.2 \%$ to $-6.1 \%$ for $\delta^{2} \mathrm{H}$ (Swart et al., 1989). The $\delta^{18} \mathrm{O}$ data from wells sampled from depths of $240 \mathrm{~m}$ and $490 \mathrm{~m}$ ranged from $-2.6 \%$ to -1.8 per mil (Meyer, 1989a). Isotopic values in southwest Florida for the UFA have been reported in the range of $-1.69 \%$ to $-0.08 \% \delta^{18} \mathrm{O}$ and $-8.79 \%$ to $-1.53 \% 0 \delta^{2} \mathrm{H}$, suggesting a meteoric recharge source. In the LFA, reported isotopic values have been reported to range from $+0.12 \%$ to $+0.73 \%$ $\delta^{18} \mathrm{O}$ and $+0.02 \%$ to $+3.72 \% \delta^{2} \mathrm{H}$. suggesting a seawater source (Rectenwald, 2000). Morrissey et al. (2010) distinguished waters in the FAS in central and south Florida in part by $\delta^{18} \mathrm{O}$ values, and described groundwater groups based on salinity, relative age, and recharge origin, with recharge in the upper aquifers consistent with recharge from meteoric sources during the last glacial period (-2.8 \%o to $\left.-1.0 \% \delta^{18} \mathrm{O}\right)$, and Holocene aged recharge to the LFA and BZ from the Florida Straits $\left(+0.0 \%\right.$ to $\left.+0.4 \% 0 \delta^{18} \mathrm{O}\right)$.

\subsubsection{Background - Dissolved Gases}

Dissolved noble gases have become useful tools to investigate hydrologic processes in groundwater as atmospheric noble gases dissolved in groundwater do not typically partake in water rock interactions (Cey et al., 2009). Dissolution of gases in water is governed by Henry's Law:

$$
[i]_{g}=H_{i}[i]_{w}
$$


where $i$ is the gas species, $g$ is the concentration of the gas phase, $w$ the concentration of the water phase, and $H_{i}$ is the Henry constant. Dissolved gas concentrations in groundwater is related to atmospheric concentration by:

$[i]_{e q}\left(T, S, P_{a}\right)=\frac{[i]_{a t m}\left(T, P_{a t m}\right)}{H_{i}(T, S)}$

where $[i]_{e q}$ is air-equilibrated water (AEW), and $[i]_{a t m}$ is concentration of the gas in the atmosphere. Gas concentrations in the atmosphere are related to temperature $(T)$ and pressure $\left(P_{a t m}\right)$, and AEW is dependent on the temperature, pressure, and salinity $(S)$ of the water. Air bubbles are commonly trapped during aquifer recharge, which results in dissolved gas concentrations in groundwater exceeding concentrations that would be expected at their solubility equilibriums determined by temperature, and is often referred to as the excess air component (Stute and Schlosser, 2000). The gas exchange processes between groundwater and the atmosphere are controlled by the diffusion coefficients of the gas, which decrease with increasing molecular weight, resulting in the preferential dissolution of the heavier gases, and degassing of the lighter gases as the water table fluctuates. Entrapped air does not completely dissolve in water, and noble gas concentration ratios in water are fractionated with regards to atmospheric ratios, as the ratios will be depleted in the lighter noble gases relative to the heavier gases (Stute and Schlosser, 2000). Dissolved gas ratios are used to indicate the presence of excess air (Herzberg and Mazor, 1979; Heaton and Vogel, 1981; Stute and Schlosser, 2000). When plotted against one another, measured gas concentrations often plot to the right of expected concentrations, indicating the presence of excess air. Partially dissolved trapped 
air, loss of gas through degassing in the aquifer, or if there is a source of dissolved gas other than the atmosphere, such as injectate into the aquifer, will result in the dissolved gas ratios fractionated relative to atmospheric air.

The measured concentration of dissolved gas in water $\left([\mathrm{i}]_{\mathrm{m}}\right)$ is the sum of the concentration AEW plus the excess air concentration ([i] $\left.]_{\mathrm{ex}}\right)$, and any other sources of dissolved gas from radiogenic $\left([\mathrm{i}]_{\mathrm{rad}}\right)$ or terrigenic $\left([\mathrm{i}]_{\mathrm{terr}}\right)$ sources within the aquifer. The dissolved gas concentration in water can be written as:

$[\mathrm{i}]_{\mathrm{m}}=[\mathrm{i}]_{\mathrm{eq}}+[\mathrm{i}]_{\mathrm{ex}}+[\mathrm{i}]_{\mathrm{rad}}+[\mathrm{i}]_{\mathrm{terr}}$

Neon $(\mathrm{Ne})$ is commonly used as an indicator of excess air because there is no other source in groundwater except atmospheric Ne. Excess air is described by the relative excess of Ne (Stute and Schlosser, 2000):

$\Delta N e=\left(\frac{\left[N e_{m}\right]}{\left[N e_{e q}\right]}-1\right) x 100 \%$

Any change in dissolved air will result in a large relative change in the $\Delta \mathrm{Ne}$ because of the relatively small equilibrium component.

Three models are commonly used to interpret excess air and noble gas concentrations in water, and the reader is referred to Cey et al., (2009), for a thorough description. In summary, the three include the unfractionated air (UA) model (Heaton and Vogel, 1981), partial equilibrium (PR) model (Stute et al., 1995), and the closed system equilibrium 
(CE) model (Aeschbach-Hertig et al., 2000). The UA model is the simplest, and assumes complete dissolution of the trapped air bubbles and unfractionated excess air, therefore excess air will have the composition of atmospheric air (Stute and Schlosser, 2000). The PR model proposes a complete dissolution of the trapped air followed by a partial reequilibrium (PR) with the atmosphere via diffusive degassing, resulting in a fractionation of lighter gases depleted relative to the heavier gases. In the CE model, groundwater and trapped air bubbles are equilibrated, and fractionation of excess air results from incomplete dissolution of trapped air, with fractionation dependent on the difference solubilities of the entrapped air (Aeschbach-Hertig et al., 2000).

Dissolved gases have been used in Florida to assess sources of groundwater recharge. Studies done for assessing sources of nitrate to spring systems in northern Florida indicated concentrations of dissolved $\mathrm{N}_{2}$ and $\mathrm{Ar}$ in spring water consistent with atmospheric equilibration during groundwater recharge with minor amounts of excess air, less than $3.6 \mathrm{~cm}^{3} \mathrm{STP} / \mathrm{L}$ (Katz et al., 2004). Morrissey et al. (2010) used noble gas recharge temperatures and $\Delta \mathrm{Ne}$ to distinguish groundwater groups on the basis of recharge sources in central and south Florida. Noble gas recharge temperatures were found to range for last glacial period (LGP) fresh water $18.0-21.8^{\circ} \mathrm{C}, 23.2-26.2^{\circ} \mathrm{C}$ for Holocene fresh water, and $8.0-10.2^{\circ} \mathrm{C}$ Holocene salt water (water originating from the Florida Straits). Excess He was used to determine relative ages, with the lowest concentrations found in Holocene fresh water $\left(0.4\right.$ to $\left.6.310^{-8} \mathrm{~cm}^{3} \mathrm{STPg}^{-1}\right)$, and the highest in the LGP fresh water $\left(3.1-3610^{-8} \mathrm{~cm}^{3} \mathrm{STPg}^{-1}\right)$, reflecting the longer residence time of the LGP freshwater in the Floridan Aquifer System (Morrissey et al., 2010). 


\subsubsection{Background - Relative Age Dating Tritium/3helium}

The tritium/helium-3 $\left({ }^{3} \mathrm{H} /{ }^{3} \mathrm{He}\right)$ dating method has been used as a dating technique to assess flow and contamination in aquifers, and as a means in conjunction with particletracking analysis to improve groundwater flow model calibration (Poreda et al., 1988;

Solomon et al., 1995, Solomon and Cook, 2000; Sheets et al., 1998, Manning et al., 2005, Katz et al., 2001). The ${ }^{3} \mathrm{H} /{ }^{3} \mathrm{He}$ dating techniques have been used as a means to estimate flow paths, recharge rates, and aquifer properties (Aeschbach-Hertig, et al., 1998; Shapiro et al., 1999; Price et al., 2003), assessing susceptibility of public water supply wells to contamination (Manning et al., 2005), and to determine the chronology of nitrate contamination in spring waters in northern Florida (Katz et al., 2001). The radiogenic isotope ${ }^{3} \mathrm{H}$ is produced naturally in the upper atmosphere as a result of cosmic radiation, however large quantities of ${ }^{3} \mathrm{H}$ were released into the atmosphere during the 1950's and early 1960's as a result of thermonuclear weapons testing. Tritium concentrations in the atmosphere peaked between 1962 and 1965, when aboveground thermonuclear testing was stopped, and tritium levels in the atmosphere decreased thereafter. Precipitation measurements made prior to the 1950 's had a very low ${ }^{3} \mathrm{H}$ concentrations. Groundwaters with non-detecatable ${ }^{3} \mathrm{H}$ concentrations are considered "tritium dead" water, indicative of recharge to the aquifer prior to the 1950 's. The ${ }^{3} \mathrm{H}$ as a result of thermonuclear testing has been precipitating out of the atmosphere, and entering aquifers during recharge. Tritium decays to ${ }^{3} \mathrm{He}$ with a half life 12.32 years. The relatively short half life of tritium combined with mixing and dispersion processes in the aquifer, makes identification of the ${ }^{3} \mathrm{H}$ bomb peak difficult in groundwater systems today. However, by measuring both ${ }^{3} \mathrm{H}$ and ${ }^{3} \mathrm{He}$ in a groundwater sample, an estimate of the age of groundwater can be made 
without knowing historical ${ }^{3} \mathrm{H}$ precipitation data. The ${ }^{3} \mathrm{H} /{ }^{3} \mathrm{He}$ method can be used to determine the "age" of a water sample with a resolution of 0.1 years for young $(<40$ years old) water, with water "age" defined as the elapsed time that the water has been isolated from the atmosphere.

The ${ }^{3} \mathrm{H} /{ }^{3} \mathrm{He}$ age of a water sample is defined as:

$$
\mathrm{t}=\lambda^{-1} \ln \left(\frac{{ }^{3} \mathrm{He} *}{{ }^{3} \mathrm{H}}+1\right)
$$

where: $\lambda={ }^{3} \mathrm{H}$ decay constant, ${ }^{3} \mathrm{He}^{*}=$ tritiogenic, and ${ }^{3} \mathrm{He}$ concentration (concentration resulting from the decay of ${ }^{3} \mathrm{H}$ ). The amount of ${ }^{3} \mathrm{He}^{*}$ is derived from the mass equation for all ${ }^{3} \mathrm{He}$ sources:

$$
{ }^{3} \mathrm{He}_{\mathrm{m}}={ }^{3} \mathrm{He}_{\mathrm{eq}}+{ }^{3} \mathrm{He}_{\mathrm{ex}}+{ }^{3} \mathrm{He}^{*}+{ }^{3} \mathrm{He}_{\mathrm{nuc}}+{ }^{3} \mathrm{He}_{\mathrm{man}}
$$

With ${ }^{3} \mathrm{He}_{\mathrm{eq}}$ at equilibrium with the atmosphere, ${ }^{3} \mathrm{He}_{\mathrm{ex}}$ excess ${ }^{3} \mathrm{He},{ }^{3} \mathrm{He}_{\text {nuc }}$ of nucleogenic sources, and ${ }^{3} \mathrm{He}_{\mathrm{man}}$ of derived from the mantle. Most of the helium in air is the heavier isotope ${ }^{4} \mathrm{He}$, which is controlled by the release of terrestrial sources of ${ }^{4} \mathrm{He}$ derived from uranium and thorium-series decay. The ${ }^{3} \mathrm{He}_{\mathrm{rad}}$ and ${ }^{3} \mathrm{H}_{\text {terr }}$ derived from subsurface nuclear reactions originates primarily from the uranium-thorium-series decay and the fission of the ${ }^{6} \mathrm{Li}$ neutrons produced. The ${ }^{3} \mathrm{He}_{\mathrm{rad}} /{ }^{4} \mathrm{He}_{\text {terr }}$ produced in the earth's crust is typically $1 \mathrm{x}$ $10^{-8}$ (Mamyrin and Tolstikhin, 1984), and is two magnitudes smaller than the atmospheric ${ }^{3} \mathrm{He} /{ }^{4} \mathrm{He}$ ratio of $1.36 \times 10^{-06}$, and therefore is ${ }^{3} \mathrm{He}_{\operatorname{man}}$ is negligible for most aquifers. The 
south Florida carbonate platform is tectonically inactive, and previous south Florida ${ }^{3} \mathrm{H} /{ }^{3} \mathrm{He}$ age dating studies have made this assumption (Price et al., 2003).

To obtain the ${ }^{3} \mathrm{He} *$ measured ${ }^{3} \mathrm{He} /{ }^{4} \mathrm{He}$ ratios in analyzed groundwater samples are used. The atmospheric ${ }^{3} \mathrm{He} /{ }^{4} \mathrm{He}$ ratio is $1.384 \times 10^{-6}$ (Clark et al., 1976), however a small fractionation occurs as atmospheric helium is dissolved in precipitation which results in a ${ }^{3} \mathrm{He} /{ }^{4} \mathrm{He}$ ratio of $1.36 \times 10^{-6}$ for water in isotopic equilibrium with atmospheric helium at $10^{\circ} \mathrm{C}$. Neon is used to determine the excess air in a sample using eq. 8. Substituting all in the mass balance equation simplifies to:

${ }^{3} \mathrm{He}^{*}={ }^{4} \mathrm{He}_{\mathrm{m}} \mathrm{R}_{\mathrm{o}}-\mathrm{R}_{\mathrm{eq}}\left[{ }^{4} \mathrm{He}_{\mathrm{eq}}+\left(\mathrm{Ne}_{\mathrm{m}}-\mathrm{Ne}_{\mathrm{eq}}\right) \alpha \mathrm{R}_{\mathrm{He}-\mathrm{Ne}}\right]-\mathrm{R}_{\mathrm{rad}}\left[{ }^{4} \mathrm{He}_{\mathrm{m}}{ }^{-4} \mathrm{He}_{\mathrm{eq}}-\left(\mathrm{Ne}_{\mathrm{m}}-\mathrm{Ne}_{\mathrm{sol}}\right) \mathrm{R}_{\mathrm{He}-\mathrm{Ne}}\right]$

Where $\mathrm{R}_{\mathrm{o}}$ is $\left({ }^{3} \mathrm{He} /{ }^{4} \mathrm{He}\right)_{\mathrm{m}}$; $\mathrm{R}_{\mathrm{eq}}$ is $\left({ }^{3} \mathrm{He} /{ }^{4} \mathrm{He}\right)_{\mathrm{eq}} ; \mathrm{R}_{\mathrm{He}-\mathrm{Ne}}$ is $(\mathrm{He} / \mathrm{Ne})_{\mathrm{atm}}, \mathrm{R}_{\mathrm{rad}}$ is $\quad{ }^{3} \mathrm{He}_{\mathrm{nud}}{ }^{4} \mathrm{He}_{\mathrm{rad}}$, and $\alpha$ is the He air-water isotope fractionation factor $\left(\mathrm{R}_{\mathrm{gas}} / \mathrm{R}_{\mathrm{water}}\right)$.

Measured ${ }^{4} \mathrm{He}$ concentrations are corrected for excess air. Air corrected excess ${ }^{4} \mathrm{He}$ above the solubility equilibrium concentration at the recharge temperature is calculated using the \%-deviation of the corrected ${ }^{4} \mathrm{He}\left(\left[\mathrm{He}_{\mathrm{corr}}\right]\right)$ concentration from the equilibrium concentration $\left[H e_{e q}\right]$ :

$\Delta^{4} H e=\left(\frac{\left[H e_{c o r r}\right]}{\left[H e_{e q}\right]}-1\right) \times 100 \%$

The ${ }^{3} \mathrm{H} /{ }^{3} \mathrm{He}$ age dating technique has been used in Florida for tracing recharge in the surficial aquifer in south Florida, (Price et al., 2003), and in the unconfined portion of the 
FAS where the age of the groundwater is less than 50 years (Katz, B., 2004). The FAS in south Florida would not be a good candidate for ${ }^{3} \mathrm{H} /{ }^{3} \mathrm{He}$ age dating, as source waters have been isolated from the atmosphere pre-1950s. However at the two study sites where injectate is injected in to the $\mathrm{BZ},{ }^{3} \mathrm{H} /{ }^{3} \mathrm{He}$ age dating can be used to distinguish the injectate from native groundwater, as injectate originates from the SAS, which has a postbomb tritium signal (Price et al., 2003).

\subsection{Methods}

Water quality samples have been collected monthly since the injection wells have been in operation, and were analyzed for parameters required in the operational permits, which includes total dissolved solids, chloride and ammonia. Thirty-two samples were collected monthly representing the upper and lower zones of monitoring wells at the SD; and eight samples were collected monthly representing the upper and lower zones at the North District. Monthly injectate samples were collected at the sample port located at the effluent pump station immediately before injectate enters the main distribution pipe to the injection wells. Major ions were collected from 2006 - 2007 at both sites (Walsh and Price, 2010). Samples from the SD were collected from wells open to the UFA, MC1, APPZ, and MC2; at the ND samples were collected from wells open to the UFA/Upper $\mathrm{MC1}$, and the lower MC1/Avon Park Permeable Zone. Water quality samples were also collected at an ASR site located in western Miami-Dade County (Figure 3.1), from the monitoring well open to the lower UFA (335 - $366 \mathrm{~m}$ bls), below the ASR injection zone. The ASR facility had not been in operation except for a one month period in 2002, and injected potable water was subsequently removed in 2003 until ambient water quality was 
reached (MDWASD, W. Pitt, personal communication). Groundwater samples were collected in 2005 for $\mathrm{NH}_{4}^{+}$analysis and for ${ }^{3} \mathrm{H}-{ }^{3} \mathrm{He}$ age determinations. Samples were collected again in February 2008 for analysis of $\mathrm{NH}_{4}^{+}$, the stable isotopes $\delta^{18} \mathrm{O}, \delta^{2} \mathrm{H}$, $\delta^{15} \mathrm{~N}$, dissolved oxygen $\left(\mathrm{O}_{2}\right)$, nitrogen $\left(\mathrm{N}_{2}\right)$, carbon dioxide $\left(\mathrm{CO}_{2}\right)$, methane $\left(\mathrm{CH}_{4}\right)$, dissolved noble gases (helium, neon, argon, krypton and xenon), and tritium. Samples for $\mathrm{NH}_{4}^{+}$and for $\delta^{18} \mathrm{O}, \delta^{2} \mathrm{H}$ were filtered through a $45 \mu \mathrm{m}$ filter. The stable isotopes samples were collected into glass bottles with rubber septum stoppers and crimped with an aluminum cap; $\mathrm{NH}_{4}^{+}$samples were collected in 1liter high density polyethylene (HDP) bottles preserved with sulfuric acid. Samples for dissolved noble gases and ${ }^{3} \mathrm{H} /{ }^{3} \mathrm{He}$ age determinations were collected in copper tubes that were crimp-sealed while groundwater was flowing through the tube. Dissolved gas samples were collected in serum bottles preserved with potassium hydroxide. Tritium samples were collected in 1-L HDP bottles.

The stable isotopes analyses of $\delta^{18} \mathrm{O}, \delta^{2} \mathrm{H}$, and $\delta^{15} \mathrm{~N}$, were completed at the USGS Reston Stable Isotope Laboratory (RSIL). The $\delta^{15} \mathrm{~N}$ isotopes of $\mathrm{NH}_{4}^{+}$sample preparation was done by a combination of freeze-drying, distillation, vacuum extraction, ion exchange and combustion to isolate compounds and produce pure gaseous nitrogen for determining the relative difference in ratios of the amounts of ${ }^{15} \mathrm{~N}$ and ${ }^{14} \mathrm{~N}$ of the gas phase products by a Finnigan Delta V continuous-flow isotope-ratio mass spectrometer. Precision was approximately $\pm 0.1 \%$ (Hannon et and Böhlke, 2008). Isotopic compositions of $\delta^{18} \mathrm{O}$ and $\delta^{2} \mathrm{H}$ were determined by mass spectrometry using the methods of Epstein and Mayeda (1953), Coplen et al., (1991), and by Révész and Coplen (2008). Samples were analyzed for the dissolved gases of $\mathrm{N}_{2}, \mathrm{O}_{2}, \mathrm{Ar}, \mathrm{CO}_{2}$ and $\mathrm{CH}_{4}$ by gas chromatograph on low 
pressure headspace at the U.S. Geological Survey (USGS) Dissolved Gas Laboratory (Weiss, 1970; Weiss, 1974; Wiesenburg et al., 1979).

The $2005^{3} \mathrm{H}-{ }^{3} \mathrm{He}$ samples were analyzed at the University of Miami Noble Gas Isotope Laboratory (NGIL) using the helium in-growth method following the methods of Clark (Clark et al., 1976), with a precision of $1.5 \%$ (0.01 Tritium Units (TU)), and a detection limit of 0.015 tritium units. Analysis also included ${ }^{4} \mathrm{He},{ }^{3} \mathrm{He}$, and neon concentration measurement with precisions of $0.5 \%, 0.5 \%$, and $2 \%$, respectively. Groundwater samples collected in 2008 were analyzed by the USGS Noble Gas Laboratory in Boulder, Colorado. Both laboratories used similar methodologies. The ${ }^{3} \mathrm{He}$ and neon were first extracted for mass spectrometric analysis, and the remaining sample was then sealed in a glass container. After approximately 6 months, the in-grown ${ }^{3} \mathrm{He}$ was measured using mass spectrometry. The ${ }^{3} \mathrm{H}$ concentration was determined from the amount of in-grown ${ }^{3} \mathrm{He}$, the length of time the sample was sealed, and the radioactive decay rate (12.32 years) of tritium. Accuracy was reported to be 0.01 tritium units. The age of each groundwater sample was assumed to be equal to the time indicated by the decay of ${ }^{3} \mathrm{H}$ to ${ }^{3} \mathrm{He}$ in a closed system, after adjustments for atmospheric gas contributions and for excess terrigenic helium (Schlosser et al., 1988). For the 2005 sampling event ${ }^{3} \mathrm{H} /{ }^{3} \mathrm{He}$ age determinations, the suite of noble gases was not measured, and therefore the recharge temperature was not calculated, and the temperature of the water sample at time of collection was used instead. Changing the recharge temperatures by $\pm 5^{\circ}$ changed age calculations by less than 1.5 years, within the analytical uncertainties. 


\subsection{Results}

\subsubsection{Ammonium}

The results for $\mathrm{NH}_{4}^{+}$concentration grouped into two categories; wells with low concentrations of $\mathrm{NH}_{4}^{+} \quad(<0.02 \mathrm{mmol} / \mathrm{L})$, and those with higher concentrations. All wells in the UFA, well 2L in the APPZ, and most wells in the MC2 at the SD had concentrations of $\mathrm{NH}_{4}^{+}$less than 0.02 mmols per liter. All wells in the MC1 with the exception of $9 \mathrm{U}$ had $\mathrm{NH}_{4}^{+}$concentrations greater than $0.02 \mathrm{mmols} / \mathrm{L}$, with well $6 \mathrm{U}$ at the highest $\mathrm{NH}_{4}^{+}$concentration $\left(0.8\right.$ mmols/L). Two wells in the MC2 also had $\mathrm{NH}_{4}^{+}$ concentrations greater than $0.02 \mathrm{mmol}$ per liter. All wells in the UFA at the ND had results less than $0.02 \mathrm{mmol} / \mathrm{L} \mathrm{NH}_{4}^{+}$; all wells in the APPZ at the ND had concentrations greater than $0.02 \mathrm{mmols} / \mathrm{L}$. Injectate $\mathrm{NH}_{4}^{+}$concentrations at both sites were above 26 $\mathrm{mmol} / \mathrm{L} . \mathrm{NH}_{4}^{+}$concentration for the ASR site was 0.02 mmols per liter (Table 3.1).

\subsubsection{Stable Isotopes}

The $\delta^{15} \mathrm{~N}-\mathrm{NH}_{4}^{+} \quad$ results for the wells that had low $\mathrm{NH}_{4}^{+}$concentrations were increasingly depleted with decreasing depth in the aquifer (Figure 3.5 and Table 3.1). At the SD, $\delta^{15} \mathrm{~N}$ $\mathrm{NH}_{4}^{+}$values from wells with low $\mathrm{NH}_{4}^{+}$concentration varied from $+5.92 \%$ to $+6.9 \%$ for the UFA, $+4.85 \%$ for the lower MC1/APPZ zone, and $+0.83 \%$ to $+5.58 \%$ for the MC2 zone. The $\delta^{15} \mathrm{~N}-\mathrm{NH}_{4}^{+}$values for the UFA zone at the ND ranged from $+5.02 \%$ to +6.09 per mil. Results for the SD and ND injectate were $+7.66 \%$ and $+10.03 \%$ o respectively. Wells with elevated $\mathrm{NH}_{4}^{+}$concentration had enriched $\delta^{15} \mathrm{~N}_{-} \mathrm{NH}_{4}^{+}$values and were more enriched than the injectate values. Wells in the MC1 with elevated $\mathrm{NH}_{4}^{+}$ concentrations at the SD ranged from $+8.80 \%$ to +10.09 per mil. Results for the lower 
$\mathrm{MC} 1 / \mathrm{APPZ}$ and $\mathrm{MC} 2$ with elevated $\mathrm{NH}_{4}^{+}$concentration wells ranged from $+9.84 \%$ to +12.71 per mil. The APPZ zone at the ND ranged from $+10.66 \%$ to +12.71 per mil. At the $\mathrm{SD} \delta{ }^{15} \mathrm{~N}-\mathrm{NH}_{4}^{+}$results for the wells with elevated $\mathrm{NH}_{4}^{+}$concentrations showed an inverse correlation to $\mathrm{NH}_{4}^{+}$concentrations, with the sample with the highest $\mathrm{NH}_{4}^{+}$ concentration (well $6 \mathrm{U}$ ) closest to the injectate having the least enriched $\delta^{15} \mathrm{~N}-\mathrm{NH}_{4}^{+}$ result compared to the injectate $\delta^{15} \mathrm{~N}-\mathrm{NH}_{4}^{+}$value, and $\delta^{15} \mathrm{~N}_{-} \mathrm{NH}_{4}^{+}$values becoming more enriched with decreasing $\mathrm{NH}_{4}^{+}$concentrations (Figure 3.5).

The $\delta^{18} \mathrm{O}$ and $\delta^{2} \mathrm{H}$ of the groundwater samples with low $\mathrm{NH}_{4}^{+}$concentrations tended to group together by aquifer zone and increased with depth in the aquifer (Figure 6 and Table 3.1). Average $\delta^{18} \mathrm{O}$ and $\delta^{2} \mathrm{H}$ values were similar for the UFA at both sites (average $\delta^{18} \mathrm{O}-1.82 \%$ and $\delta^{2} \mathrm{H}-7.97 \%$ for the SD; average $\delta^{18} \mathrm{O}-1.76 \%$ and $\delta^{2} \mathrm{H}-5.67 \%$ for the North District). Wells in the $\mathrm{MC} 1$ at the SD averaged $-1.32 \%$ for $\delta^{18} \mathrm{O}$ and $-5.24 \%$ for $\delta^{2} \mathrm{H}$; wells in the APPZ at the SD averaged $-1.19 \%$ for $\delta^{18} \mathrm{O}$ and $-5.24 \%$ for $\delta^{2} \mathrm{H}$, more depleted than the APPZ zone at the North District $\left(-0.47 \%\right.$ for $\delta^{18} \mathrm{O}$ and $-0.94 \%$ for $\left.\delta^{2} \mathrm{H}\right)$. The MC2 results averaged $+0.20 \%$ for $\delta^{18} \mathrm{O}$ and $-3.60 \%$ for $\delta^{2} \mathrm{H}$. Wells with low $\mathrm{NH}_{4}^{+}$concentrations from the $\mathrm{MC} 2$ had isotopic values more positive than seawater. The MC2 wells with elevated $\mathrm{NH}_{4}^{+}$concentrations had more depleted isotopic values than wells with low $\mathrm{NH}_{4}^{+}$concentrations Injectate values for the $\mathrm{SD}$ and the ND were similar $\left(\delta^{18} \mathrm{O}\right.$ of $-1.36 \%$ and $\delta^{2} \mathrm{H}$ of $-5.57 \%$ for the SD; $\delta^{18} \mathrm{O}$ of $-1.35 \%$ and $\delta^{2} \mathrm{H}$ of $-4.08 \%$ for the ND). Most of the groundwater samples tended to plot on a line with a slope less than the meteoric line that also intersected the $\delta^{18} \mathrm{O}$ and $\delta^{2} \mathrm{H}$ value of Miami 
rainfall (Figure 3.6). The isotopic compositions of the injectate also plotted along the same line as most of the groundwater samples and Miami rainfall (Figure 3.6).

\subsubsection{Dissolved Gases}

Concentrations of $\mathrm{N}_{2}$ from wells with low $\mathrm{NH}_{4}^{+}$concentrations grouped together by aquifer and tended to decrease with depth (Figure 3.7 and Table 3.1). Concentrations of $\mathrm{N}_{2}$ for the UFA at the SD averaged $0.583 \mathrm{mmols} / \mathrm{L}$, while the $\mathrm{MC} 2$ average concentration was slightly lower at 0.555 mmols per liter. At the $\mathrm{ND}$, groundwater $\mathrm{N}_{2}$ concentrations within the UFA zone averaged 0.667 mmols per liter (Figure 3.8).

Dissolved $\mathrm{O}_{2}$ concentrations were less than $0.010 \mathrm{mmols} / \mathrm{L}$ for all wells at both the SD and the ND (Table 3.1). Concentrations of Argon, $\mathrm{CO}_{2}$ and $\mathrm{CH}_{4}$ were very similar for all wells with low $\mathrm{NH}_{4}^{+}$concentrations (Figure 3.6), with concentrations of Argon ranging from $0.014 \mathrm{mmols} / \mathrm{L}$ to $0.016 \mathrm{mmols}$ per liter. Dissolved $\mathrm{CO}_{2}$ concentrations were below $0.20 \mathrm{mmols} / \mathrm{L}$ for all low $\mathrm{NH}_{4}^{+}$concentration wells (Figure 3.7). Concentrations of $\mathrm{CH}_{4}$ for low $\mathrm{NH}_{4}^{+}$concentration wells at the SD were below $0.002 \mathrm{mmols} / \mathrm{Lfor}$ the UFA, and below 0.001 for the MC2; while at the ND UFA zone concentrations of $\mathrm{CH}_{4}$ were less than 0.01 mmols per liter.

Injectate dissolved gas concentrations were $0.012 \mathrm{mmols} / \mathrm{L}$ and $0.020 \mathrm{mmols} / \mathrm{L}$ in $\mathrm{O}_{2}$ for the $\mathrm{SD}$ and ND respectfully, and $0.418 \mathrm{mmols} / \mathrm{L}$ and $0.561 \mathrm{mmols} / \mathrm{L}$ for nitrogen gas. Argon results for injectate were similar for both sites (Table 3.1 and Figure 3.7). The injectate SD had a $\mathrm{CO}_{2}$ concentration of $3.010 \mathrm{mmols} / \mathrm{L}$; the ND injectate $\mathrm{CO}_{2}$ concentration was 2.473 mmols per liter. Concentrations of $\mathrm{CH}_{4}$ were detected in the 
injectate at the both sites at very low levels, $0.0005 \mathrm{mmols} / \mathrm{L}$ and $0.0049 \mathrm{mmols} / \mathrm{L}$, respectively.

Argon concentrations for the $\mathrm{MC} 1$ zone at the $\mathrm{SD}$ ranged from $0.019 \mathrm{mmols} / \mathrm{L}$ to 0.030 mmols/L, with the highest Argon concentration from the well sample with the highest $\mathrm{NH}_{4}^{+}$concentration (well 6U) (Figure 3.7). Argon concentrations from the wells with elevated $\mathrm{NH}_{4}^{+}$concentrations in the MC2 averaged 0.021 mmols per liter. Argon concentrations in the APPZ at the ND averaged $0.021 \mathrm{mmols}$ per liter (Figure 3.8). Wells with elevated $\mathrm{NH}_{4}^{+}$concentrations for the $\mathrm{MC} 1$ at the $\mathrm{SD}$ had dissolved $\mathrm{CO}_{2}$ concentrations ranging from $0.045 \mathrm{mmols} / \mathrm{L}$ to $0.703 \mathrm{mmols} / \mathrm{L}$, with the highest $\mathrm{CO}_{2}$ concentration from the well sample that had the highest $\mathrm{NH}_{4}^{+}$concentration (well $6 \mathrm{U}$ ). Samples collected from the wells with elevated $\mathrm{NH}_{4}^{+}$concentrations in the $\mathrm{MC} 2$ averaged $0.061 \mathrm{mmols} / \mathrm{L}$. Samples collected from the ND APPZ had an average $\mathrm{CO}_{2}$ concentration of 0.124 mmols per liter (Figure 3.8). Concentrations of $\mathrm{CH}_{4}$ for the wells with elevated $\mathrm{NH}_{4}^{+}$concentrations in the $\mathrm{MC} 1$ from the $\mathrm{SD}$ range from $0.0285-0.0813$ $\mathrm{mmols} / \mathrm{L}$, and were $0.0156 \mathrm{mmols} / \mathrm{L}$ and $0.0534 \mathrm{mmols} / \mathrm{L}$ for the two wells in the MC2 with elevated $\mathrm{NH}_{4}^{+}$concentrations. Concentrations of $\mathrm{CH}_{4}$ from the $\mathrm{APPZ}$ at the $\mathrm{ND}$ were less than $0.02 \mathrm{mmols}$ per liter (Figure 3.8).

Concentrations of excess air in groundwater were calculated from values of argon, with the assumption that the samples contained argon from air-water equilibrium and dissolution of excess air. All wells with elevated $\mathrm{NH}_{4}^{+}$concentrations had excess argon 
concentrations, with the highest concentration of excess argon in the injectate and well 6-upper (Table 3.1).

Helium and neon concentrations for wells with low $\mathrm{NH}_{4}^{+}$concentrations at the SD averaged $202.3 \mu \mathrm{ccSTP} / \mathrm{kg}$ and $203.8 \mu \mathrm{ccSTP} / \mathrm{kg}$ for the UFA, and from 179.5 $\mu \mathrm{ccSTP} / \mathrm{kg}$ to $184.5 \mu \mathrm{ccSTP} / \mathrm{kg}$ for the MC2 ambient wells (Figure 3.9 and Table 3.2). At the ND, wells in the UFA had average helium and neon concentrations of 165.15 $\mu \mathrm{ccSTP} / \mathrm{kg}$ and $235.2 \mu \mathrm{ccSTP} / \mathrm{kg}$, respectively. Krypton concentrations averaged 74.4 $\mu \mathrm{ccSTP} / \mathrm{kg}$ and $77.8 \mu \mathrm{ccSTP} / \mathrm{kg}$ for the UFA and MC2 wells with low $\mathrm{NH}_{4}^{+}$ concentrations, respectively. Xenon concentrations averaged $9.6 \mu \mathrm{ccSTP} / \mathrm{kg}$ for the UFA and $10.5 \mu \mathrm{ccSTP} / \mathrm{kg}$ for the wells with low $\mathrm{NH}_{4}^{+}$concentrations in the MC2. Concentrations for the UFA zones at the ND were similar to the South District (Table 3.2 and Figure 3.9).

At the SD, injectate concentrations for helium and neon were $26.9 \mu \mathrm{ccSTP} / \mathrm{kg}$ and 159.9 $\mu \mathrm{ccSTP} / \mathrm{kg}$, respectively. Helium concentrations ranged from $49.8 \mu \mathrm{ccSTP} / \mathrm{kg}$ to 168.1 $\mu \mathrm{ccSTP} / \mathrm{kg}$ for the wells with elevated $\mathrm{NH}_{4}^{+}$concentrations in the $\mathrm{MC} 1$ zone, and 110.1 $\mu \mathrm{ccSTP} / \mathrm{kg}$ to $119.3 \mu \mathrm{ccSTP} / \mathrm{kg}$ for wells with elevated $\mathrm{NH}_{4}^{+}$concentrations in the MC2 zone, with the lowest concentrations correlating to the highest $\mathrm{NH}_{4}^{+}$concentrations (well $6 \mathrm{U})$. Neon results were similar to the helium results, with the lowest neon concentration of $161.7 \mu \mathrm{ccSTP} / \mathrm{kg}$ from well 6-upper. Krypton and xenon results from the wells with elevated $\mathrm{NH}_{4}^{+}$concentrations followed the same pattern as argon, with the highest 
concentrations ( $210.2 \mu \mathrm{ccSTP} / \mathrm{kg}$ for krypton and $20.6 \mu \mathrm{ccSTP} / \mathrm{kg}$ for xenon)

corresponding to well 6-upper (Table 3.2 and Figure 3.9).

Injectate at the ND had concentrations of $60.9 \mu \mathrm{ccSTP} / \mathrm{kg}$ for helium, $230.8 \mu \mathrm{ccSTP} / \mathrm{kg}$ for neon, and $0.649 \mathrm{ccSTP} / \mathrm{kg}$ for argon, however concentrations of krypton (496.2 $\mu \mathrm{ccSTP} / \mathrm{kg})$ and xenon $(146.5 \mu \mathrm{ccSTP} / \mathrm{kg}$ ) were extremely high, which may have been a result of small bubbles in the $\mathrm{O}_{2}$ mix (USGS, A. Hunt, personal communication, 2009). Concentrations for helium for the ND APPZ wells ranged from 48.8 to $67.6 \mu \mathrm{ccSTP} / \mathrm{kg}$; concentrations of neon and argon were very similar for all wells in the APPZ and averaged $175.1 \mu \mathrm{ccSTP} / \mathrm{kg}$ and $0.4 \mathrm{ccSTP} / \mathrm{kg}$, respectively (Table 3.2 and Figure 3.9). Krypton and xenon concentrations were also very similar for all wells in the APPZ at the ND (114.0 $\mu \mathrm{ccSTP} / \mathrm{kg}$ and $13.3 \mu \mathrm{ccSTP} / \mathrm{kg}$, respectively).

\subsubsection{Tritium and Apparent ${ }^{3} \mathrm{H} /{ }^{3} \mathrm{He}$ Ages}

Tritium results are reported in tritium units (TU). Tritium concentrations from the 2005 and 2008 sampling events were similar (Table 3.1).Tritium levels for wells with low $\mathrm{NH}_{4}^{+}$ concentrations at both sites were at or below $0.5 \mathrm{TU}$. Tritium levels for the SD injectate were similar for both sampling events, with the 2005 results $7.8 \mathrm{TU}$, and the 2008 results 8.98 tritium units. Tritium levels at the SD were similar for both sampling events as well, with the highest tritium reported for well $6 \mathrm{U}$ (7.00 TU in 2005 and $7.09 \mathrm{TU}$ in 2008) which also had the highest $\mathrm{NH}_{4}^{+}$concentration. The ND injectate samples for both sampling events were lost during transport. The ND APPZ wells had results ranging from 
1.9 to $3.7 \mathrm{TU}$ for the 2005 sampling event, and $2.46 \mathrm{TU}$ to $4.36 \mathrm{TU}$ for the 2008 sampling event.

\subsection{Discussion}

\subsubsection{Injectate characteristics}

Injectate at both sites is characterized as having high $\mathrm{NH}_{4}^{+}$concentrations $(>26$

mmols/L), and enriched $\delta^{15} \mathrm{~N}^{-N_{4}} H_{4}^{+}, \delta^{18} \mathrm{O}$, and $\delta^{2} \mathrm{H}$ values (Table 3.1). Injectate samples had $\delta^{15} \mathrm{~N}-\mathrm{NH}_{4}^{+}$results in the range reported for domestic sewage, and similar to values reported for sewage contaminated groundwater in the Florida Keys (Clark and Fritz, 1997; Böhlke et al., 2003). Values of $\delta^{18} \mathrm{O}$ and $\delta^{2} \mathrm{H}$ of the injectate at both sites were similar to values reported for the Biscayne Aquifer (Swart et al., 1989; Price and Swart, 2006; Price et al., 2008), which is the original source of the injectate water. At both the $\mathrm{SD}$ and the ND, cryogenic oxygen plants produce gaseous purified oxygen gas $\left(\mathrm{O}_{2}\right)$ that is piped to the plant biological oxygenation reactors. Once through the reactors, it enters the effluent stream for deep well disposal. As a result of the cryogenic process, the injectate is enriched in $\mathrm{CO}_{2}$ and the heavier gases (argon, krypton and xenon), but depleted in oxygen gas (consumed in the oxygenation reactors) and the lighter gases ( $\mathrm{N}_{2}$, helium and neon) (Table 3.2).

\subsubsection{Ambient Water Quality and Recharge source}

Concentrations of $\mathrm{NH}_{4}^{+}$, stable isotopes, tritium, and dissolved gas results from this study were compared to other reported values for the FAS that were not associated with deep well injection sites, to determine ambient water quality and possible recharge source 
waters for each aquifer zone. Concentration results of $\mathrm{NH}_{4}^{+}$for the 2008 sampling event showed the same low and high concentration groupings at both sites similar to previous studies (Walsh and Price, 2010). Groundwater $\mathrm{NH}_{4}^{+}$concentrations equivalent to or less than $0.02 \mathrm{mmol} / \mathrm{L}$ were similar to the results for the ASR site, and to other reported $\mathrm{NH}_{4}^{+}$ concentrations for in the Floridan Aquifer system (Walsh and Price, 2010). All wells with $\mathrm{NH}_{4}^{+}$concentrations less than $0.02 \mathrm{mmols} / \mathrm{L}$ contained no measureable tritium (Table 3.1), as would be expected for FAS ambient water, and further evidence that samples with low $\mathrm{NH}_{4}^{+}$concentrations are representative of ambient water quality. Wells with low $\mathrm{NH}_{4}^{+}$concentrations also had values of $\delta^{15} \mathrm{~N}-\mathrm{NH}_{4}^{+}$below $+6.9 \%$, less than the injectate $\delta^{15} \mathrm{~N}-\mathrm{NH}_{4}^{+}$value, indicating that the source of $\mathrm{NH}_{4}^{+}$in these samples is not from injectate. The $\delta^{15} \mathrm{~N}-\mathrm{NH}_{4}^{+}$results grouped together for samples with low $\mathrm{NH}_{4}^{+}$concentrations for each hydrogeologic zone, and decreased with increasing depth in the aquifer (Figure 3.4). The average $\delta^{15} \mathrm{~N}^{-\mathrm{NH}_{4}^{+}}\left(3.39 \%\right.$, ) for samples collected from the MC2 low $\mathrm{NH}_{4}^{+}$ concentrations wells at the SD were within the range of $\delta^{15} \mathrm{~N}^{-N_{4}}{ }_{4}^{+}$values of +2.8 to $+4.5 \%$ reported for deep saline water in other geographic areas (Böhlke and Krantz, 2003). Work done in the Florida Keys indicated that anoxic marine ground water in the Keys contained significant amounts of $\mathrm{NH}_{4}^{+}(10-80 \mu \mathrm{mol} / \mathrm{L})$, with $\delta^{15} \mathrm{~N}$ values of $+3 \%$, to $+8 \%$, and noted that possibly much of the groundwater $\mathrm{NH}_{4}^{+}$was produced naturally by anaerobic degradation of nitrogen bearing organic matter in sediments (Böhlke et al., 2003). Native aquifer waters at the two sites in the current study have low levels of ammonium (less than $20 \mu \mathrm{mols} / \mathrm{L}$ ), with a similar range of $\delta^{15} \mathrm{~N}-\mathrm{NH}_{4}^{+}$, which may indicate a similar biogeochemical source of $\mathrm{NH}_{4}^{+}$in the aquifer. 
Values of $\delta^{18} \mathrm{O}$ and $\delta^{2} \mathrm{H}$ for the UFA at both sites and the ASR site are consistent with reported values for the Floridan Aquifer System (Rechtenwald, 2000; Morrisey et al., 2010). The average UFA values of $\delta^{18} \mathrm{O}$ and $\delta^{2} \mathrm{H}$ fell below the MWL, indicating water that has undergone evaporation prior to recharging the aquifer and suggest an evaporative fresh water recharge source (Figure 3.5). Although geothermal heating could affect the isotopic ratios, geothermal gradients are not observed in the FAS ( Kohout, 1965; Walsh and Price, 2010), and the of $\delta^{18} \mathrm{O}$ and $\delta^{2} \mathrm{H}$ values are likely indicative of evaporation, and not geothermal heating. The $\delta^{18} \mathrm{O}$ values fall within the range interpreted as meteoric recharge during the last glacial period (Rechtenwald, 2000; Morrisey et al., 2010). Values of $\delta^{18} \mathrm{O}$ and $\delta^{2} \mathrm{H}$ from wells with low $\mathrm{NH}_{4}^{+}$concentrations from the SD MC2 averaged $0.2 \%$ and $3.6 \%$, similar to other reported LFA values, with $\delta^{18} \mathrm{O}$ value for the MC2 within the range reported for the LFA and BZ interpreted as Holocene seawater recharge from the Florida Straits (Morrisey et al., 2010). The $\delta^{18} \mathrm{O}$ and $\delta^{2} \mathrm{H}$ values for well 2L at the SD collected from the MC1/APPZ (501 - 510 m depth) was slightly enriched than the UFA values, but were lighter than the ambient samples collected from the deeper MC2 zone. These results are similar to the chloride data trends for this zone previously reported (higher $\mathrm{Cl}^{-}$concentration than the UFA, but lower than the MC2), and represents the transition zone in the FAS from the saline LFA to the brackish Floridan Aquifer System (Reese, 1994; Walsh and Price, 2010).

Sources of recharge were inferred by comparing neon concentrations to the heavier noble gases (Figure 3.9). An equilibrium line is drawn for water in equilibrium with the atmosphere, or air saturated water (ASW), and air saturated seawater (ASSW) at different 
temperatures, and assuming excess air is not fractionated, data points can be extrapolated out towards the equilibrium line (Heaton and Vogel, 1981). Comparison of neon and xenon concentrations indicated UFA at both sites and MC1 wells at the SD with low $\mathrm{NH}_{4}^{+}$concentrations fall along equilibrium lines suggesting freshwater recharge origin (Figure 3.9). These wells lie along an air saturated fresh water (ASW) equilibrium line with increasing excess air with depth in the aquifer, and suggested recharge temperatures are similar to LGP freshwater recharge temperatures. Samples collected from wells 2L and 9L at the SD lie in this freshwater trend, and suggest that samples from these wells may lie in the transition between Holocene seawater recharge and LGP freshwater recharge, consistent with interpretations of chloride data (Walsh and Price, 2010) and the $\delta^{18} \mathrm{O}$ and $\delta^{2} \mathrm{H}$ data.

Wells with low $\mathrm{NH}_{4}^{+}$concentrations from the $\mathrm{MC} 2$ at the $\mathrm{SD}$ had neon concentrations close to the air saturated seawater (ASSW) ratio for seawater at $8^{\circ} \mathrm{C}$, and slightly to the right of the equilibrium line suggesting some excess air component (Figure 3.10). The recharge temperature of $8^{\circ} \mathrm{C}$ is similar to recharge temperatures determined by Morrissey et al. (2010) for the LFA and similar to temperatures in the Florida Straits at depths where the BZ outcrops. The recharge temperature is consistent with Holocene seawater recharge from the Florida Straits, and the slight excess air component may indicate residual mixing of encroaching seawater from the Florida Straits with native water. The previous major ion study observed low variance in ion concentrations among samples collected from wells with low $\mathrm{NH}_{4}^{+}$concentrations within each hydrogeologic zone (Walsh and Price, 2010), and this is also observed with the stable isotopes and dissolved 
gas data. Wells with low $\mathrm{NH}_{4}^{+}$concentrations from each zone showed distinct dissolved gas concentrations clustering along the equilibrium line, and values for $\delta^{18} \mathrm{O}, \delta^{2} \mathrm{H}$ and $\delta^{15} \mathrm{~N}-\mathrm{NH}_{4}^{+}$were also observed to cluster by hydrogeologic zone. The low variance between samples within each zone, as well as the distinct clustering suggests recharge in each of these zones originates under different environmental conditions, and that as these distinctions are still observable would imply there is minimal hydrologic connection between the zones.

\subsubsection{Evidence of injectate migration}

Previous studies concluded that samples with $\mathrm{NH}_{4}^{+}$concentrations greater than 0.02 $\mathrm{mmol} / \mathrm{L}$ contained some injectate (Walsh and Price, 2010). Using this criteria, the 2008 sampling event resulted in the same wells interpreted as containing some injectate as in the previous study, and at the SD includes most wells in the $\mathrm{MC1}$, (with the highest $\mathrm{NH}_{4}^{+}$ concentration in well 6U), two wells in the MC2, and all wells in the APPZ at the ND. Analysis of ${ }^{3} \mathrm{H} /{ }^{3} \mathrm{He}$ apparent ages, and stable isotope and dissolved gas data reinforce this interpretation.

The ${ }^{3} \mathrm{H} /{ }^{3} \mathrm{He}$ apparent age results agree with the $\mathrm{NH}_{4}^{+}$concentrations interpretation, with all wells with low $\mathrm{NH}_{4}^{+}$concentrations containing no measureable tritium, and wells with elevated $\mathrm{NH}_{4}^{+}$concentrations with tritium concentrations considered post-bomb peak (Table 3.1). The ${ }^{3} \mathrm{H} /{ }^{3} \mathrm{He}$ age results were plotted against the $\mathrm{NH}_{4}^{+}$concentrations, and samples were observed to fall into interpreted age categories described as old, (ambient or prebomb), mixed, and new injectate (Figure 3.10), with mixed being a mixture of old 
water (ambient) and new water (injectate). All samples determined to be representative of ambient conditions based on $\mathrm{NH}_{4}^{+}$concentrations, stable isotope and dissolved gas data grouped together in the old category, reflecting the pre-bomb ${ }^{3} \mathrm{H} /{ }^{3} \mathrm{He}$ apparent age (Figure 3.11). Wells 6U, 12L and 14U (wells with the highest $\mathrm{NH}_{4}^{+}$concentrations ) were classified in the new injectate category, with ${ }^{3} \mathrm{H} /{ }^{3} \mathrm{He}$ age results indicating fairly recent injectate recharge in the areas of these wells. The rest of the elevated $\mathrm{NH}_{4}^{+}$concentration wells fell in the mixed age group. Well BZL fell into mixed and old categories; this well is in location of a monitoring well drilled into the $\mathrm{BZ}$ at the start of injection operations in the early 1980's, and which was in the early 1990's plugged and abandoned (MDWASD, 1995). The overlap of ages at well BZL suggests that the injectate present there was a remnant from pre-abandonment times.

Samples collected from wells with elevated $\mathrm{NH}_{4}^{+}$concentration had enriched $\delta{ }^{15} \mathrm{~N}-\mathrm{NH}_{4}{ }^{+}$ values, similar to those reported for sewage effected water systems in south Florida (Böhlke et al., 2003) and Cape Cod, Massachusetts (Böhlke et al., 2006), and were more enriched than the $\delta^{15} \mathrm{~N}-\mathrm{NH}_{4}^{+}$values for the injectate samples, indicating injectate being a

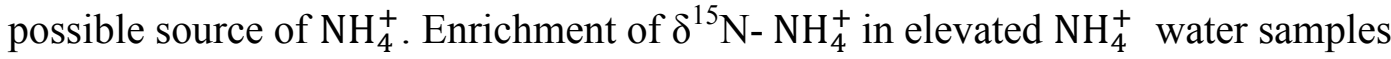
suggests that there may be chemical, physical or biological kinetic processes that are affecting $\mathrm{NH}_{4}^{+}$transport through the aquifer. Fractionation of ${ }^{15} \mathrm{~N}$ associated with cation exchange reactions has been reported to be minor to negligible (Böhlke et al., 2006), therefore some preferentially fractionation reactive process in groundwater may be occurring. 
At the SD, well samples with elevated $\mathrm{NH}_{4}^{+}$concentrations in the $\mathrm{MC} 1$ had $\delta^{18} \mathrm{O}$ and $\delta^{2} \mathrm{H}$ values similar to the injectate, but isotopically lighter than the ambient MC2 groundwater (Figure 3.5). A binary plot of $\delta^{18} \mathrm{O}$ and $\mathrm{NH}_{4}^{+}$data indicated two distinct mixing lines: one from the injecate to the ambient groundwater in $\mathrm{MC} 2$; and the second from the injectate through the wells in $\mathrm{MCl}$ with elevated $\mathrm{NH}_{4}^{+}$concentrations. The separation of the two mixing lines indicate no mixing between the MC2 and the $\mathrm{MC} 1$, which would be expected if injectate was migrating upwards from the BZ (Figure 3.12). The APPZ well data for the ND shows a mixing line from the injectate, however, there is little variance between data, and data do not show a gradual mixing as seen in the SD data (Figure $3.13)$.

At the $\mathrm{SD}$, wells with elevated $\mathrm{NH}_{4}^{+}$concentrations showed a positive correlation between heavier noble gases, (example xenon and neon) and $\mathrm{NH}_{4}^{+}$concentrations $\left(\mathrm{R}^{2}=\right.$ 0.83), and an inverse correlation between the lighter gases and $\mathrm{NH}_{4}^{+}$(Figure 3.10 ). Samples that were collected from wells with elevated $\mathrm{NH}_{4}^{+}$concentrations show a mixing trend towards well $6 \mathrm{U}$, with samples from the $\mathrm{SD}$ with of the highest $\mathrm{NH}_{4}^{+}$concentration (wells 14U and 6U) closest to the injectate points (Figure 3.10). Argon and xenon concentrations in wells with the highest $\mathrm{NH}_{4}^{+}$concentration (wells $14 \mathrm{U}$ and $6 \mathrm{U}$ ) were higher than the injectate concentrations. Injectate would be the only source of heavier noble gases recharge to the aquifers. Injectate concentrations are highly seasonal based on incoming flows to the wastewater treatment plants (Walsh and Price, 2010), and therefore noble gas concentrations may also fluctuate with treatment volumes, and this may be reflected in the higher concentrations in the aquifer samples. These higher 
concentrations would also suggest that dispersion may play a negligible role in the transport of injectate, at least in wells with higher $\mathrm{NH}_{4}^{+}$concentrations. Well $6 \mathrm{U}$ from the SD illustrates this, as $\mathrm{NH}_{4}^{+}$and noble gas concentrations are similar to injectate. Unlike the SD, APPZ samples from the ND show influence of the injectate, however there is minimal variance in the xenon and neon concentrations (Figure 3.8). The binary plot of xenon and neon showed that all elevated $\mathrm{NH}_{4}^{+}$concentrations samples did not fall along the ASSW or the ASW equilibrium line (as did all wells with low $\mathrm{NH}_{4}^{+}$concentrations), but rather plotted off along a mixing line in the area of the injectate endmember (Figure $3.10)$.

\subsubsection{Evidence of Geochemical Reactions}

Concentrations of $\mathrm{CO}_{2}$ and $\mathrm{CH}_{4}$ were inversely correlated, and may suggest methanogenesis is occurring in the aquifer (Figure 3.6). Injectate had high concentrations of $\mathrm{CO}_{2}$ as a result of the cryogenic process at both WWTPs, with very low concentrations of $\mathrm{CH}_{4}$. Ambient concentrations of $\mathrm{CO}_{2}$ and $\mathrm{CH}_{4}$ were very low. Wells with the highest $\mathrm{NH}_{4}^{+}$concentrations had the highest $\mathrm{CO}_{2}$ and $\mathrm{CH}_{4}$ concentrations. As injectate and ambient water have low $\mathrm{CH}_{4}$ concentrations, it appears that once $\mathrm{CO}_{2}$ is introduced into the aquifer, methane production commences. Wells with lower $\mathrm{NH}_{4}^{+}$concentrations have $\mathrm{CO}_{2}$ concentrations similar to ambient, which may indicate the consumption of introduced $\mathrm{CO}_{2}$ in the methanogenesis process. Methane concentrations appear to persist in the aquifer once produced, and concentrations seem to follow the same mixing trends as other chemical parameters. 
The FAS is an anoxic, very reducing environment with sulfate (concentrations ranging from 3 to $25 \mathrm{mmols} / \mathrm{L}$, with concentrations increasing with depth in the aquifer) acting as the electron donors for microbial energy and biomass production (Lisle, J., unpublished data, Walsh and Price, 2010). Evidence of anaerobic oxidation of $\mathrm{NH}_{4}^{+}$involves the analysis of concentrations and isotopic compositions of not only $\mathrm{NH}_{4}^{+}$, but also $\mathrm{NO}_{3}^{-}$and $\mathrm{N}_{2}$ (Bölke et al., 2006, Clark etal., 2008), which were not done for this study. Concentrations of $\mathrm{NO}_{3}^{-}$for all samples at both sites were less than $5 \mu \mathrm{mols} / \mathrm{L}$, and as the FAS and the injectate is anoxic $(<0.02 \mathrm{mmols} / \mathrm{L})$, this would indicate minimal conditions for denitrification in the aquifer. Progressive enrichment of $\delta^{15} \mathrm{~N}^{-\mathrm{NH}_{4}^{+}}$in the aquifer may be evidence of anaerobic oxidation by annamox bacteria (Clark et al., 2008; Bölke et al., 2006). Anaerobic oxidation of $\mathrm{NH}_{4}^{+}$with the reduction of $\mathrm{NO}_{2}^{-}$according to the equation (Van de Graaf et al., 1995; Thamdrup and Dalsgaard, 2002):

$\mathrm{NH}_{4}^{+}+\mathrm{NO}_{2}^{-}=\mathrm{N}_{2}+2 \mathrm{H}_{2} \mathrm{O}$

Measured $\mathrm{NO}_{2}^{-}$concentrations in injectate were $6 \mu$ mols. Concentrations in the wells with elevated $\mathrm{NH}_{4}^{+}$concentrations were never greater than $1 \mu \mathrm{mol} / \mathrm{L}$ (Walsh and Price, 2010). On the basis of the stoichiometry of the above annamox equation, it may be that all of the introduced $\mathrm{NO}_{2}^{-}$is consumed in the reaction, and $\mathrm{NO}_{2}^{-}$is the limiting reactant. Concentrations of $\mathrm{NH}_{4}+$ decrease along hypothesized flow paths (Walsh and Price, 2010), however, as all wells with elevated $\mathrm{NH}_{4}^{+}$concentrations had $1 \mu \mathrm{mol} / \mathrm{L}$ or less of $\mathrm{NO}_{2}^{-}$, there would be minimal production of $\mathrm{N}_{2}$ along these flowpaths. Evidence of anammox can also be $\mathrm{N}_{2}$ overpressuring with increasing $\delta{ }^{15} \mathrm{~N}^{-\mathrm{NH}_{4}}{ }^{+}$values, however, 
since ambient water $\mathrm{N}_{2}$ concentrations are higher than injectate, increasing $\mathrm{N}_{2}$ concentrations with decreasing $\mathrm{NH}_{4}^{+}$concentrations could be the result of mixing with $\mathrm{N}_{2}$ ambient water, and any production of $\mathrm{N}_{2}$ as a result of equation 13 would be negligible. The gas $\mathrm{N}_{2}$ is inversely correlated with $\mathrm{NH}_{4}^{+}\left(\mathrm{r}^{2}=0.88\right)$ at the $\mathrm{SD}$, showing similar correlations as the other nonreactive gases, and therefore concentrations of $\mathrm{N}_{2}$ are expected regardless of any anammox reactions. It would appear though that $\mathrm{NH}_{4}^{+}$may be oxidized once it is introduced into the aquifer. Well 6U shows a decrease of $\mathrm{NH}_{4}^{+}$concentrations from that of the injectate, however, $\mathrm{Ne}, \mathrm{Ar}$ and $\mathrm{Kr}$ are very similar to injectate concentrations. Assuming non-retardation of $\mathrm{NH}_{4}^{+}$in any aquifer sediments, it may be that there is some reactive $\mathrm{NH}_{4}^{+}$loss in the aquifer once injectate is introduced; once the limiting reactant has been consumed there appears to be no further loss of $\mathrm{NH}_{4}^{+}$, and it follows mixing trends similar to nonreactive injectate components. This is illustrated by Figure 3.6, where data shows a mixing line from well $6 \mathrm{U}$, more so than from the injectate.

\subsubsection{Evidence of Vertical Pathways}

Samples for this study were collected from open borehole intervals ranging from a few meters to over 40 meters, and water samples collected consisted of mixed waters from the various aquifer zones open to each borehole, rather than discrete intervals. Samples collected from the monitoring well zones containing injectate (as indicated by elevated $\mathrm{NH}_{4}^{+}$concentrations) were mixed water composed of water fractions from the aquifer zone (which in itself may be a mixture of water from different hydrologic zones within the open borehole), injectate, and any possibly BZ and LFA waters if the injectate mixed 
with those waters as it migrated upwards through those aquifer zones. If injectate were to migrate through the lower confining zones of the LFA as a result of buoyant flow transport, water quality taken from the monitoring wells in the MC2 at the SD and the APPZ at the ND, (zones closest to the LFA and the BZ) should show the strongest freshwater signal, and would expect that signal to slowly dissipate as the water migrated upward through the aquitard mixing with native waters. If vertical flow paths exist as a result of natural or anthropogenic causes then the freshwater recharge signal may not dissipate as quickly, as these pathways may provide a relatively quick transport path with little mixing of native waters, with water quality mirroring injectate water quality. Analysis of the historical water quality data collected at both sites indicated several plumes of injectate located in the overlying aquifers, with $\mathrm{NH}_{4}^{+}$detected in upper monitoring wells, and not in their companion lower monitoring zone, indicating that at least for some wells migration upwards through the confining layers was unlikely (Starr et al., 2001; Walsh and Price, 2010). Well 6U in the MC1 at the SD consistently had dissolved gas concentrations and stable isotope values very similar to injectate concentrations, with wells $14 \mathrm{U}$ and $16 \mathrm{U}$ also following that trend, and had ${ }^{3} \mathrm{H} /{ }^{3} \mathrm{He}$ apparent ages interpreted as recent. Noble gas concentrations for well $6 \mathrm{U}$ show concentrations very similar to the injectate concentration, and binary plots of noble gases and $\mathrm{NH}_{4}^{+}$concentrations clearly show a mixing from injectate, and not from the underlying aquifer zones, as would be expected if injectate was migrating upwards through the underlying zones rather than through vertical pathways (Figures 3.6 and 3.8). These observations would suggest that some type of vertical pathway exists in the vicinity of the borehole of well $6 \mathrm{U}$ that allows the vertical migration of injectate with 
minimal amount of mixing of native waters as it migrates upwards. Data from wells $14 \mathrm{U}$ and $16 \mathrm{U}$ may also indicate a vertical pathway from the $\mathrm{BZ}$ to the $\mathrm{MC1}$, bypassing the confining layers. Data do not show any mixing trends between these MC1 samples and the $\mathrm{MC} 2$. The strong correlations at the $\mathrm{SD}$ between $\mathrm{NH}_{4}^{+}$concentrations and tritium and the non-reactive heavier noble gases would suggest that once $\mathrm{NH}_{4}^{+}$is introduced into the $\mathrm{MC1}$, it is transported mainly via advection, and gradually mixes with native waters as the plume dissipates out from the source.

Although injectate could possibly migrate from the area of well $6 \mathrm{U}$ horizontally to wells $14 \mathrm{U}$ and $16 \mathrm{U}$, there would need to be some sort of horizontal preferential pathway, that would bypass the aquifer in the vicinity of wells lying between $6 \mathrm{U}$ and $14 \mathrm{U} / 16 \mathrm{U}$ (see Figure 3.1). That could possibly be the case with well 14U, however, well 9U lies between $6 \mathrm{U}$ and 16-upper. Well 9U has concentrations considered ambient, and had an older relative age than wells $6 \mathrm{U}$ and $16 \mathrm{U}$, suggesting that there may be a vertical pathway in the vicinity of the borehole of $16 \mathrm{U}$ as well. Reactive species concentrations $\left(\mathrm{NH}_{4}^{+}\right.$, $\mathrm{CO}_{2}$, and $\mathrm{CH}_{4}$ ) are high in well $6 \mathrm{U}$, and lower in well $9 \mathrm{U}$, indicating possible horizontal reaction pathway once the injectate is introduced, as discussed earlier. These species however are again elevated in well $16 \mathrm{U}$ compared to well 9U, which would indicate that the source of the higher reactive species in well $16 \mathrm{U}$ is not from horizontal advective flow from the direction of well 9U, but rather from another area of upward migration of injectate. The ${ }^{3} \mathrm{H} /{ }^{3} \mathrm{He}$ apparent ages of wells $6 \mathrm{U}$ (recent), 9U (older) and 16U (recent) also indicate that injectate present in wells $6 \mathrm{U}$ and $16 \mathrm{U}$ may be of different vertical pathways. 
The MDWASD concluded ammonia present at the ND was a result of construction problems (MDWASD, 2005), however, this study does not support that hypothesis. Samples collected for the 2008 sampling event show that $\mathrm{NH}_{4}^{+}$concentrations have remained persistent in the $\mathrm{MC} 1$, which would not be the expected case if a one-time pulse of injectate was introduced into the aquifer. There is very little variance in all data sets for the APPZ wells at the ND, and data has been remarkably homogenous for all parameters analyzed in this study. Data show injectate as the source of the $\mathrm{NH}_{4}^{+}$in the APPZ, and also show no mixing trends with the lower saline zones. The homogeneity of the data may indicate there is no on-site or nearby vertical pathway (as is evident at the $\mathrm{SD}$ ), but does not disprove the existence of an off-site source of $\mathrm{NH}_{4}^{+}$, that then migrates to the site with the groundwater flow. Work done by King et al. (2009) at the ND used analytical models to test various injectate flow paths, and concluded at the ND an off-site confinement bypass source was the most likely. Work by Cunningham and Walker has indicated fractures, faults and seismic-sag structural systems in the rocks of the FAS from seismic-reflection data acquired in Biscayne Bay in south Florida, nearby the two study sites, and these structures may also provide transport pathways for the injectate (Cunningham and Walker, 2009). Walsh and Price (2010) analyzed the aquifer geochemistry at both sites and their conclusions were that the geochemistry indicated multiple pathways for migration. Assuming that water quality in the LFA and the BZ is similar to water quality at the SD in these zones, review of the stable isotope and dissolved gas data do not indicate mixing of water from the lower zones in the APPZ samples, but rather show similar mixing patterns as wells in the MC1 at the SD interpreted as horizontal flow from some vertical pathway. This would be consistent with 
King's interpretation of an off-site source, where wells at the ND are located in the injectate horizontal pathway located some distance from the bypass feature.

\subsection{Conclusions}

On the basis of $\mathrm{NH}_{4}^{+}$concentrations, and by stable isotope and dissolved gas data, all wells in the UFA at both sites are considered representative of ambient water quality, with no evidence of upward migration of injectate. The conclusion is consistent with previous findings for the Upper Floridan Aquifer.

Injectate is characterized by high $\mathrm{NH}_{4}^{+}$concentrations, enriched $\delta^{15} \mathrm{~N}-\mathrm{NH}_{4}^{+}$values, depleted lighter dissolved gases, and enriched in heavier noble gases. Samples collected from wells with elevated $\mathrm{NH}_{4}^{+}$concentrations showed enriched $\delta{ }^{15} \mathrm{~N}-\mathrm{NH}_{4}^{+}$values greater than injectate values, and mixing trends back to the injectate, with the source of higher heavier noble gas concentrations in these wells only being possible from injectate. These wells also had elevated tritium levels, which also could only be a result of recharge after the 1950 's, consistent with injectate age. The injectate is therefore concluded to be the source of elevated $\mathrm{NH}_{4}^{+}$concentrations found in the $\mathrm{MC} 1, \mathrm{APPZ}$ and the $\mathrm{MC} 2$ at both sites.

There is evidence of multiple vertical bypass features at the SD, however no evidence of these features were observed in the data at the ND. Confinement bypass features were observed in different locations at the SD, suggesting several plumes may exist on site, consistent with previous findings. Data suggest injectate present in the APPZ at the ND may be the result of an offsite vertical bypass feature. 
Evidence of some type of methanogenesis and $\mathrm{NH}_{4}^{+}$oxidation reactions were observed in the data. Microbial activity under high pressure and salinity environments such found in the $\mathrm{BZ}$ and the overlying zones in the FAS has not been extensively researched. This study suggests that further understanding of these processes may be of value, as current federal regulations require high level disinfection (HLD) prior to injection at municipal deep well injection facilities in south Florida due to the possibility of survival and migration of pathogens to an underground source of drinking water. A better understanding of microbial activity under environmental conditions found in the FAS may validate or repudiate the necessity of HLD prior to injection. 
Aeschbach-Hertig, W., P. Schlosser, M. Stute, J. J. Simpson, A. Ludin, and J. F. Clark. 1998. A ${ }^{3} \mathrm{H} /{ }^{3} \mathrm{He}$ study of ground water flow in a fractured bedrock aquifer. Ground Water 36:661-670.

Aeschbach-Hertig, W., F. Peeters, U. Beyerle, and R. Kipfer. 2000. Palaeotemperature reconstruction from noble gases in ground water taking into account equilibration with entrapped air. Nature, 405: 1040-1044.

Böhlke, J. K., and D.E. Krantz. 2003. Isotope geochemistry and chronology of offshore ground water beneath Indian River Bay, Delaware. U.S. Geological Survey Water-Resources Investigations, WRI-03-4191, 37 p.

Böhlke, J. K., E. Shinn, C. Reich, and A. Tihansky. 2003. Origins and isotopic characteristics of dissolved nitrogen species in ground water, imported domestic water, and wastewater in the Florida Keys. in US. Geological Survey Greater Everglades Science Program: 2002 Biennial Report. , Open File Report 03-54.

Böhlke, J. K., and J. M. Denver. 1995. Combined use of groundwater dating, chemical, and isotopic analyses to resolve the history and fate of nitrate contamination in two agricultural watersheds, Atlantic coastal plain, Maryland. Water Resources Research 31:2319-2339.

Böhlke, J. K., Smith, R. L., and D. N. Miller. 2006. Ammonium transport and reaction in contaminated groundwater: Application of isotope tracers and isotope fractionation studies. Water Resources Research 42. doi:10.1029/2005WR004349.

Cey, B. D., G.B. Hudson, J. E. Moran, and B. R. Scanlon. 2009. Evaluation of Noble Gas Recharge Temepratures in a Shallow Unconfined Aquifer. Groundwater, 47:649659.

Clark, I., and P. Fritz. 1997. Environmental Isotopes in Hydrogeology. CRC Press LLC, Boca Raton.

Clark, I., R. Timlin, A. Bourbonnais, K. Jones, D. Laflleur, and K. Wickens. 2008. Origin and Fate of Industrial Ammonium in Anoxic Ground Water $-{ }^{15} \mathrm{~N}$ Evidence for Anaerobic Oxidation (Annamox). Ground Water Monitoring \& Remediation, 28:73-82.

Clarke, W. B., W. J. Jenkins, and Z. Top. 1976. Determination of tritium by mass spectrometric measurement of ${ }^{3}$ He. Int. J. Appl. Radiat. and Isot. 27:515-522. 
Coplen, T.B., J.D Wildman, and J. Chen. 1991. Improvements in the gaseous hydrogenwater equilibrium technique for hydrogen isotope ratio analysis: Analytical Chemistry, 63:910-912.

Corbett, D. R., L. Kump, K. Dillon, W. Burnett, and J. Chanton. 2000. Fate of wastewater-borne nutrients under low discharge conditions in the subsurface of the Florida Keys, USA. Marine Chemistry 69:99-115.

Craig, H. 1961. Isotopic variations in natural waters. Science, 133, p. $1702-1703$.

Cunningham, K. J. and C. Walker. 2009. Seismic-sag structural systems in tertiary carbonate rocks beneath Southeastern Florida, USA, Hypogene Speleogenesis and Karst Hydrogeology of Artesian Basins, Special Paper 1, Ukrainian Institute of Speleology and Karstology

Dausman, A. M., J. Doherty, C. D. Langevin, and J. Dixon. 2010. Hypothesis testing of bouyant plume migration using a highly parameterized variable-density groundwater model at a site in Florida, USA. Hydrogeology Journal, 18:147-160.

Epstein, S., and T. Mayeda, 1953. Variation of ${ }^{18} \mathrm{O}$ content of waters from natural sources: Geochimica et Cosmochimica Acta, 4:213-224.

Fish, J. E., and M. Stewart. 1991. Hydrogeology of the surficial aquifer system, Dade County, Florida. U.S. Geological Survey Water-Resources Investigations Report 90-4108, 50 p, 11 pls.

Fukada, T., K. M. Hiscock, and P. F. Dennis. 2004. A dual-isotope approach to the nitrogen hydrochemistry of an urban aquifer. Applied Geochemistry, 19:709-719.

Griggs, E. M., L. R. Kump, and J. K. Böhlke. 2003. The fate of wastewater-derived nitrate in the subsurface of the Florida Keys: Key Colony Beach, Florida. Estuarine Coastal and Shelf Science 58:517-539.

Hanshaw, B. B., W. Back, and R. Meyer. 1965. Radiocarbon determinations for estimating groundwater flow velocities in Central Florida. Science, 148:494-495.

Hannon, J. E., and J. K. Böhlke. 2008. Determination of the $\delta\left({ }^{15} \mathrm{~N} /{ }^{14} \mathrm{~N}\right)$ of ammonium $\left(\mathrm{NH}_{4}{ }^{+}\right)$in water: RSIL lab code 2898 in Révész, $\mathrm{K}$, and T. B. Coplen, eds., Methods of the Reston Stable Isotope Laboratory: U.S. Geological Survey, Techniques and Methods.

Heaton, T. H. E., and J.C. Vogel. 1981. "Excess air' in groundwater. Journal of Hydrology, 50:201-216.

Herzberg, O., and E. Mazor. 1979. Hydrological applications of noble gases and temperatures measurements in underground water systems: examples fron Israel. Journal of Hydrology, 41: 271-231. 
Katz, B. G., T. B. Coplen, T. D. Bullen, and J. H. Davis. 1997. Use of Chemical and Isotopic Tracers to Characterize the Interactions Between Ground Water and Surface Water in Mantled Karst. Ground Water, 35:1014-1028.

Katz, B. G. 2004. Sources of nitrate contamination and age of water in large arstic springs of Florida. Environmental Geology, 46:89-706.

Katz, B. G., J. K. Böhlke, and H. D. Hornsby. 2001. Timescales for nitrate contamination of spring waters, northern Florida, USA. Chemical Geology, 179:167-186.

Kendall, C., and R. Aravena. 2000. Nitrate Isotopes in Groundwater Systems. Pages 261297 in P. G. Cook and A. L. Herzog, editors. Environmental Tracers in Subsurface Hydrology. Kluwer Academic Publishers, Boston, MA.

King, J. N., V. Walsh, K. J. Cunningham, F. S. Evans, C. D. Langevin, and A. Dausman. 2009. Analytical models of the transport of deep-well injectate at the North District Wastewater Treatment Plant, Miami-Dade County, Florida, U.S.A.: Eos, Vol. 90, Number 52, 29 December 2009, Fall Meet Supl., Abstract H21C-0869, 1 page.

Kohout, F. A. 1965. A hypothesis concerning cyclic flow of salt water related to geothermal heating in the Floridan aquifer. Trans. N.Y. Acad. Sci., Ser. II 28:249271.

Lapointe, B. E., J. D. O'Connell, and G. S. Garrett. 1990. Nutrient Couplings between onsite sewage disposal systems, groundwater, and nearshore surface waters of the Florida Keys. Biogeochemistry, 10:289-308.

Maliva, R. G., W. Guo, and T. Missimer. 2007. Vertical Migration of municipal wastewater in deep injection well systems, South Florida, USA. Hydrogeology Journal, 15:1387-1396.

Mamyrin, B. A., and I. N. Tolstikhin. 1984. Helium Isotopes in Nature. Elsevier, New York, $273 \mathrm{pp}$.

Manning, A. H., D. K. Solomon, and S. A. Thiros. $2005 .{ }^{3} \mathrm{H} /{ }^{3} \mathrm{He}$ age data in assessing the susceptibility of wells to contamination. Ground Water, 43:353-367.

McNeill, D. F. 2000. Final Report: A Review of Upward Migration of Effluent Related to Subsurface Injection at Miami-Dade Water and Sewer South District Plant: McNeill Geological Services Inc., Miami, FL.

Meyer, F. W. 1989a. Hydrogeology, Ground-Water Movement, and Subsurface Storage in the Floridan Aquifer System in Southern Florida. Professional Paper 1403-G, U.S. Geological Survey, Washington, D.C. 
Meyer, F. W. 1989b. Subsurface storage of liquids in the Floridan Aquifer System in south Florida. Open-File Report 88-477 Open-File Report 88-477, U.S. Geological Survey, Tallahassee, Fl.

Meyers, J.B., Swart, P.K., and J.L.Meyers, 1993. Geochemical evidence for groundwater behavoir in an unconfined aquifer, south Florida. Journal of Hydrology, 148:249272.

Miami-Dade Water and Sewer Department (MDWASD). 1995. Plugging and Abandonment of BZ Well Cluster, South District Wastewater Treatment Plant, Miami-Dade Water and Sewer Department, Dade County, Florida.

Miami-Dade Water and Sewer Department (MDWASD). 2005. Monitoring well purging report for North District Wastewater Treatment Plant, Miami-Dade Water and Sewer Department, Dade County, Florida. Miami-Dade Water and Sewer Department, Miami, Florida.

Miller, J. A. 1986. Hydrogeologic Framework of the Floridan Aquifer System in Florida and in Parts of Georgia, Alabama, and South Carolina. Professional Paper 1403-B Professional Paper 1403-B, U.S. Geological Survey, Washington, D.C.

Morrisey, S. K., J. F. Clark, M. Bennett, E. Richardson, and M. Stute. 2010. Groundwater reorganization in the Floridan aquifer following Holocene sea-level rise. Nature Geoscience, 3:683-687.

Plummer, L N, 1977. Defining reactions and mass transfer in part of the Floridan Aquifer: Water Resources Research, 13:801-812.

Poreda, R. J., T. E. Cerling, and D. K. Solomon. 1988. Tritium and helium isotopes as hydrologic tracers in a shallow unconfined aquifer. Journal of Hydrology, 103:19.

Price, R.M., 2001. Geochemical determinations of groundwater flow in Everglades National Park, Ph.D. dissertation, University of Miami, 307 p.

Price, R.M., and P.K. Swart. 2006. Geochemical indicators of groundwater recharge in the surifical aquifer system, Everglades National Park, Florida, USA. Geological Society of America Special Paper 404:251 - 265.

Price, R.M., Swart, P.K. and H. E. Willoughby, 2008. Seasonal and spatial variation in the stable isotopic composition $\left(\delta^{18} \mathrm{O}\right.$ and $\left.\delta \mathrm{D}\right)$ of precipitation in south Florida. Journal of Hydrology, 358:193-205.

Price, R. M., Z. Top, J. D. Happell, and P. K. Swart. 2003. Use of tritium and helium to define groundwater flow conditions in Everglades National Park. Water Resources Research, 39:1267. 
Rectenwald, E. E., 2000. Utilizing Stable Isotopes $\left({ }^{2} \mathrm{H},{ }^{18} \mathrm{O}\right)$ and Radiocarbon $\left({ }^{14} \mathrm{C}\right)$ Data to Better Understand the Hydrogeologic Framework of the Floridan Aquifer System in Southwest Florida. South Florida Water Management District, WS-21, 20 pages.

Reese, R. S. 1994. Hydrogeology and the Distribution and Origin of Salinity in the Floridan Aquifer System, Southeastern Florida. Water-Resources Investigations Report 94-4010, U.S. Geological Survey, Tallahassee, Florida.

Reese, R. S, and E. Richardson. 2008. Synthesis of the Hydrogeologic Framework of the Floridan Aquifer System and Delineation of a Major Avon Park Permeable Zone in Central and Southern Florida. Scientific Investigations Report 2007-5207. U.S. Geological Survey, Reston, VA.

Révész, K., and T. B. Coplen. 2008. Determination of the $\delta\left({ }^{2} \mathrm{H} /{ }^{1} \mathrm{H}\right)$ of water: RSIL lab code 1574, chap. C1 of Révész, K., and T. B. Coplen, eds., Methods of the Reston Stable Isotope Laboratory: U.S. Geological Survey Techniques and Methods 10$\mathrm{C} 1,27 \mathrm{p}$.

Rust Environmental and Infrastructure Inc. 1998. Report No. 1: Geochemical Study Report for South District Wastewater Treatment Plant, Dade County, Florida.

Sacks, L. A. 1995. Geochemical and Isotopic Composition of Ground Water with Emphasis on Sources of Sulfate in the Upper Floridan Aquifer in Parts of Marion, Sumter, and Citrus Counties, Florida. U.S. Geological Survey, Water Resources Investigations Report 95-4251, $47 \mathrm{pp}$.

Schlosser, P., Stute, M., Dörr, H., Sonntag, C., and Münnich, K.O. 1988. Tritium/ ${ }^{3}$ He in shallow groundwater. Earth Planet. Sci. Letters, v. 89(3/4), p. 353-362. Shapiro, S.D., LeBlanc, D., Schlosser, P. Ludin, A., 1999. Characterizing a Sewage Plume Using the ${ }^{3} \mathrm{H}-{ }^{3} \mathrm{He}$ Dating Technique. Ground Water, 37:861-878.

Sheets, R. A., E. S. Bair, and G. L. Rowe. 1998. Use of ${ }^{3} \mathrm{H} /{ }^{3} \mathrm{He}$ ages to evaluate and improve groundwater flow models in a complex buried-valley aquifer. Water Resources Research, 34:1077-1089.

Shinn, E. A., R. S. Reese, and C. D. Reich. 1994. Fate and pathways of injection-well effluent in the Florida Keys. Open-File Report Open-File Report 94-276, U.S. Geological Survey.

Solomon, D. K., A. Hunt, and R. J. Poreda. 1996. Source of radiogenic helium 4 in shallow aquifers: Implications for dating young groundwater. Water Resources Research, 32:1805-1813. 
Solomon, D. K., and P. G. Cook. 2000. ${ }^{\mathrm{e}} \mathrm{H}$ and ${ }^{3}$ He. Pages 397-424 in P. G. Cook and A. L. Herzog, editors. Environmental Tracers in Subsurface Hydrology. Kluwer Academic Publishers, Boston, MA.

Solomon, D. K., R. J. Poreda, P. G. Cook, and A. Hunt. 1995. Site Characterization using ${ }^{3} \mathrm{H} /{ }^{3} \mathrm{He}$ ground-water ages, Cape Cod, MA. Ground Water, 33:988-996.

Sprinkle, C. L. 1989. Geochemistry of the Floridan Aquifer System in Florida and in Parts of Georgia, South Carolina, and Alabama. Professional Paper 1403-I, U.S. Geological Survey, Washington, D.C.

Starr, R. C., T. S. Green, and L. C. Hull. 2001. Evaluation of confining layer integrity beneath the South District Wastewater treatment Plant, Miami-Dade Water and Sewer Department, Dade County, Florida. INEEL/EXT-2001-00046, Geosciences Research Department, Idaho National Engineering and Environmental Laboratory, Idaho Falls, Idaho.

Stute, M., M. Forster, H. Frischkorn, A. Serejo, J. F. Clark, P. Schlosser, W. S. Broeker, and G. Bonani. 1995. Cooling of tropical Brazil $\left(5^{\circ} \mathrm{C}\right)$ during the last glacial maximum. Science, 269: 379-383.

Stute, M. S., and P. Schlosser. 2000. Atmospheric Noble Gases. in P. G. Cook and A. L. Herzog, editors. Environmental Tracers in Subsurface Hydrology. Kluwer Academic Publishers, Boston, MA.

Swancar, A. and C. B. Hutchinson, 1992. Chemical and Isotopic Composition and Potential for Contamination of Water in the Upper Floridan Aquifer, WestCentral Florida. U.S. Geological Survey, Open File Report 92-47.

Swart, P. K., L. S. L. Sternberg, R. P. Steinen, and S.A. Harrison. 1989. Controls on the oxygen and hydrogen isotopic composition of the waters of Florida Bay, USA. Chemical Geology, 79:91-98.

Thamdrup, B., and T. Dalsgaard. 2002. Production of $\mathrm{N}_{2}$ through anaerobic ammonium oxidation coupled to irtrate drduction in marine sediments. Applied Environmental Microbiology, 68:1312-1318.

Tihansky A. B., and L. A. Sacks. 1997. Evaluation of nitrate sources using nitrogenisotope techniques in shallow ground water within selected lake basins in the Central Lakes District, Polk and Highland counties, Florida. U.S. Geological Survey WRI-97-4207.

Van de Graaf, A. A., A. Mulder, P. De Bruijn, M. S. Jetten, L. A. Robertson, and J. G. Kuene. 1995. Anaerobic oxidation of ammonium is a biologically mediated process. Applied Environmental Microbiology, 61:1246-1251. 
Walsh, V., and R. M. Price. 2010. Determination of vertical and horizontal pathways of injected fresh wastewater into a deep saline aquifer (Florida, USA) using natural chemical tracers. Hydrogeology Journal, 18:1027-1042.

Weiss, R. F. 1970. The solubility of nitrogen, oxygen and argon in water and seawater. Deep-Sea Research and Oceanographic Abstracts, 17:721-735.

Weiss, R.F. 1974. Carbon Dioxide in water and seawater; the solubility of a non-ideal gas. Marine Geochemistry, 2:203-215.

Wiesenburg, D. A., and N. L. Guinasso. 1979. Journal of Chemical Engineering Data, 24:356-360. 


\subsection{Tables}

Table 3.1 Ammonium, stable isotope, dissolved gases and ${ }^{3} \mathrm{H} /{ }^{3} \mathrm{He}$ data.

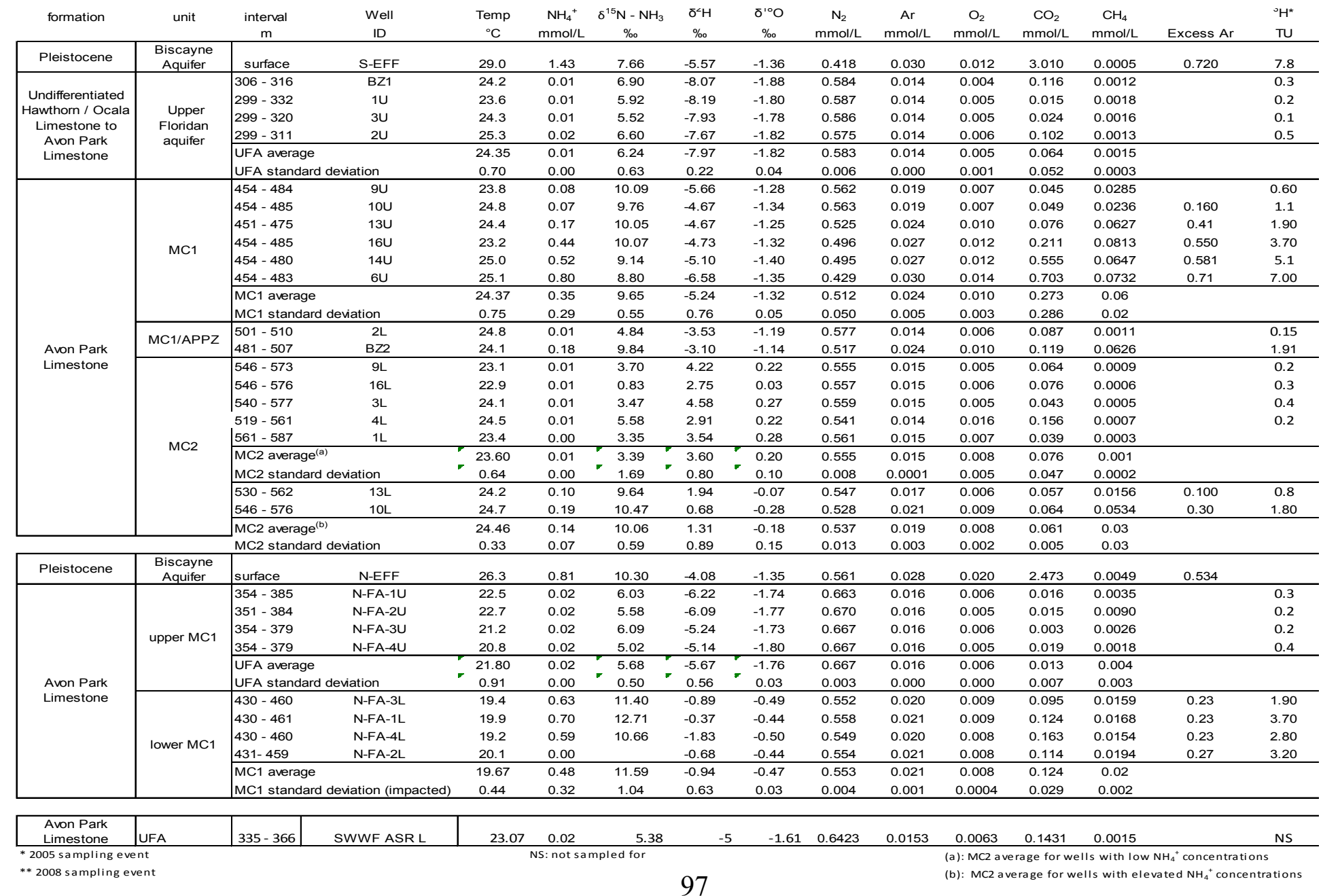


Table 3.2 Dissolved noble gas concentrations

\begin{tabular}{|c|c|c|c|c|c|c|c|c|}
\hline Pleistocene & $\begin{array}{l}\text { Biscayne } \\
\text { Aquifer }\end{array}$ & surface & S-EFF & 26.9 & 159.9 & 0.648 & 208.75 & 13.99 \\
\hline \multirow{6}{*}{$\begin{array}{l}\text { Undifferentiated } \\
\text { Hawthorn / } \\
\text { Ocala } \\
\text { Limestone to } \\
\text { Avon Park } \\
\text { Limestone }\end{array}$} & \multirow{6}{*}{$\begin{array}{l}\text { Upper } \\
\text { Floridan } \\
\text { aquifer } \\
\text { (UFA) }\end{array}$} & $306-316$ & BZ1 & 208.9 & 205.0 & 0.331 & 73.51 & 9.86 \\
\hline & & $299-332$ & $1 U$ & 195.5 & 202.9 & 0.322 & 74.52 & 9.63 \\
\hline & & $299-320$ & $3 U$ & 209.5 & 207.3 & 0.323 & 79.42 & 9.39 \\
\hline & & $299-311$ & $2 U$ & 195.2 & 199.8 & 0.308 & 70.03 & 9.35 \\
\hline & & \multirow{2}{*}{\multicolumn{2}{|c|}{$\begin{array}{l}\text { UFA average } \\
\text { UFA standard deviation }\end{array}$}} & 202.3 & 203.8 & 0.3 & 74.4 & 9.6 \\
\hline & & & & 8.0 & 3.2 & 0.0 & 3.9 & 0.2 \\
\hline \multirow{21}{*}{$\begin{array}{l}\text { Avon Park } \\
\text { Limestone }\end{array}$} & \multirow{8}{*}{ MC1 } & $454-484$ & $9 U$ & 168.1 & 192.9 & 0.423 & 111.2 & 12.22 \\
\hline & & $454-485$ & $10 U$ & 146.5 & 184.7 & 0.368 & 93.55 & 10.69 \\
\hline & & $451-475$ & $13 U$ & 120.0 & 173.8 & 0.463 & 116.6 & 13.12 \\
\hline & & $454-485$ & $16 U$ & 85.8 & 169.9 & 0.647 & 188.3 & 20.84 \\
\hline & & $454-480$ & $14 U$ & 80.3 & 168.2 & 0.602 & 176.0 & 18.80 \\
\hline & & $454-483$ & $6 \mathrm{U}$ & 49.8 & 161.7 & 0.707 & 210.2 & 20.86 \\
\hline & & MC1 aver & & 108.4 & 175.2 & 0.5 & 149.3 & 16.1 \\
\hline & & MC1 stan & eviation & 44.4 & 11.5 & 0.1 & 48.1 & 4.6 \\
\hline & \multirow{2}{*}{ MC1/APPZ } & $501-510$ & $2 \mathrm{~L}$ & 147.7 & 194.7 & 0.328 & 72.79 & 9.40 \\
\hline & & $481-507$ & $\mathrm{BZ2}$ & 115.7 & 176.0 & 0.553 & 138.7 & 15.68 \\
\hline & \multirow{11}{*}{ MC2 } & $546-573$ & $9 \mathrm{~L}$ & 204.8 & 224.2 & 0.329 & 80.03 & 10.12 \\
\hline & & $546-576$ & $16 \mathrm{~L}$ & 170.8 & 174.6 & 0.343 & 84.06 & 11.09 \\
\hline & & $540-577$ & $3 L$ & 189.8 & 173.8 & 0.311 & 72.88 & 10.14 \\
\hline & & $519-561$ & $4 \mathrm{~L}$ & 166.4 & 175.6 & 0.311 & 73.60 & 10.17 \\
\hline & & $561-587$ & $1 \mathrm{~L}$ & 165.9 & 174.2 & 0.328 & 78.43 & 10.98 \\
\hline & & \multirow{2}{*}{\multicolumn{2}{|c|}{$\begin{array}{l}\text { MC2 } \text { average* }^{*} \\
\text { MC2 } \text { standard deviation* }\end{array}$}} & 179.5 & 184.5 & 0.3 & 77.8 & 10.5 \\
\hline & & & & 17.2 & 22.2 & 0.0 & 4.6 & 0.5 \\
\hline & & $530-562$ & $13 \mathrm{~L}$ & 128.5 & 169.2 & 0.355 & 88.90 & 11.09 \\
\hline & & $546-576$ & $10 \mathrm{~L}$ & 110.1 & 148.6 & 0.447 & 112.1 & 13.13 \\
\hline & & \multicolumn{2}{|c|}{ MC2 average $^{* *}$} & 119.3 & 158.9 & 0.4 & 100.5 & 12.1 \\
\hline & & \multicolumn{2}{|c|}{ MC2 standard deviation** } & 12.98 & 14.57 & 0.07 & 16.40 & 1.44 \\
\hline
\end{tabular}

\begin{tabular}{|c|c|c|c|c|c|c|c|c|}
\hline Pleistocene & $\begin{array}{c}\text { Biscayne } \\
\text { Aquifer }\end{array}$ & surface & $\mathrm{N}-\mathrm{EFF}$ & 60.9 & 230.8 & 0.649 & 496.2 & 146.5 \\
\hline \multirow{12}{*}{$\begin{array}{l}\text { Avon Park } \\
\text { Limestone }\end{array}$} & \multirow{6}{*}{ upper MC1 } & $354-385$ & N-FA-1U & 162.8 & 234.6 & 0.359 & 82.20 & 10.45 \\
\hline & & $351-384$ & N-FA-2U & 165.2 & 234.3 & 0.356 & 79.05 & 10.39 \\
\hline & & $354-379$ & N-FA-3U & 168.5 & 235.7 & 0.356 & 80.88 & 10.44 \\
\hline & & $354-379$ & N-FA-4U & 164.1 & 236.0 & 0.353 & 85.15 & 10.30 \\
\hline & & \multirow{2}{*}{\multicolumn{2}{|c|}{$\begin{array}{l}\text { UFA average } \\
\text { UFA standard deviation }\end{array}$}} & 165.1 & 235.2 & 0.4 & 81.8 & 10.4 \\
\hline & & & & 2.4 & 0.8 & 0.0 & 2.6 & 0.1 \\
\hline & \multirow{6}{*}{ lower MC1 } & $430-460$ & N-FA-3L & 63.2 & 177.0 & 0.445 & 112.7 & 13.08 \\
\hline & & $430-461$ & N-FA-1L & 48.9 & 171.8 & 0.444 & 116.6 & 13.20 \\
\hline & & $430-460$ & N-FA-4L & 67.8 & 179.7 & 0.453 & 111.1 & 13.50 \\
\hline & & $431-459$ & N-FA-2L & 48.8 & 172.0 & 0.457 & 115.6 & 13.48 \\
\hline & & \multirow{2}{*}{\multicolumn{2}{|c|}{$\begin{array}{l}\text { MC1 average } \\
\text { MC1 standard deviation }\end{array}$}} & 57.2 & 175.1 & 0.4 & 114.0 & 13.3 \\
\hline & & & & 9.8 & 3.9 & 0.0 & 2.6 & 0.2 \\
\hline
\end{tabular}

\begin{tabular}{l|l|lllllll}
\hline $\begin{array}{l}\text { Avon Park } \\
\text { Limestone }\end{array}$ & UFA & $335-366$ & SWWF ASR-MW-1L & 319.8 & 230.4 & 0.354 & 77.91 & 10.17 \\
\hline
\end{tabular}

* MC2 average for wells with low $\mathrm{NH}_{4}{ }^{+}$concentrations

** $\mathrm{MC2}$ a verage for wells with elevated $\mathrm{NH}_{4}{ }^{+}$concentrations 


\subsection{Figures}

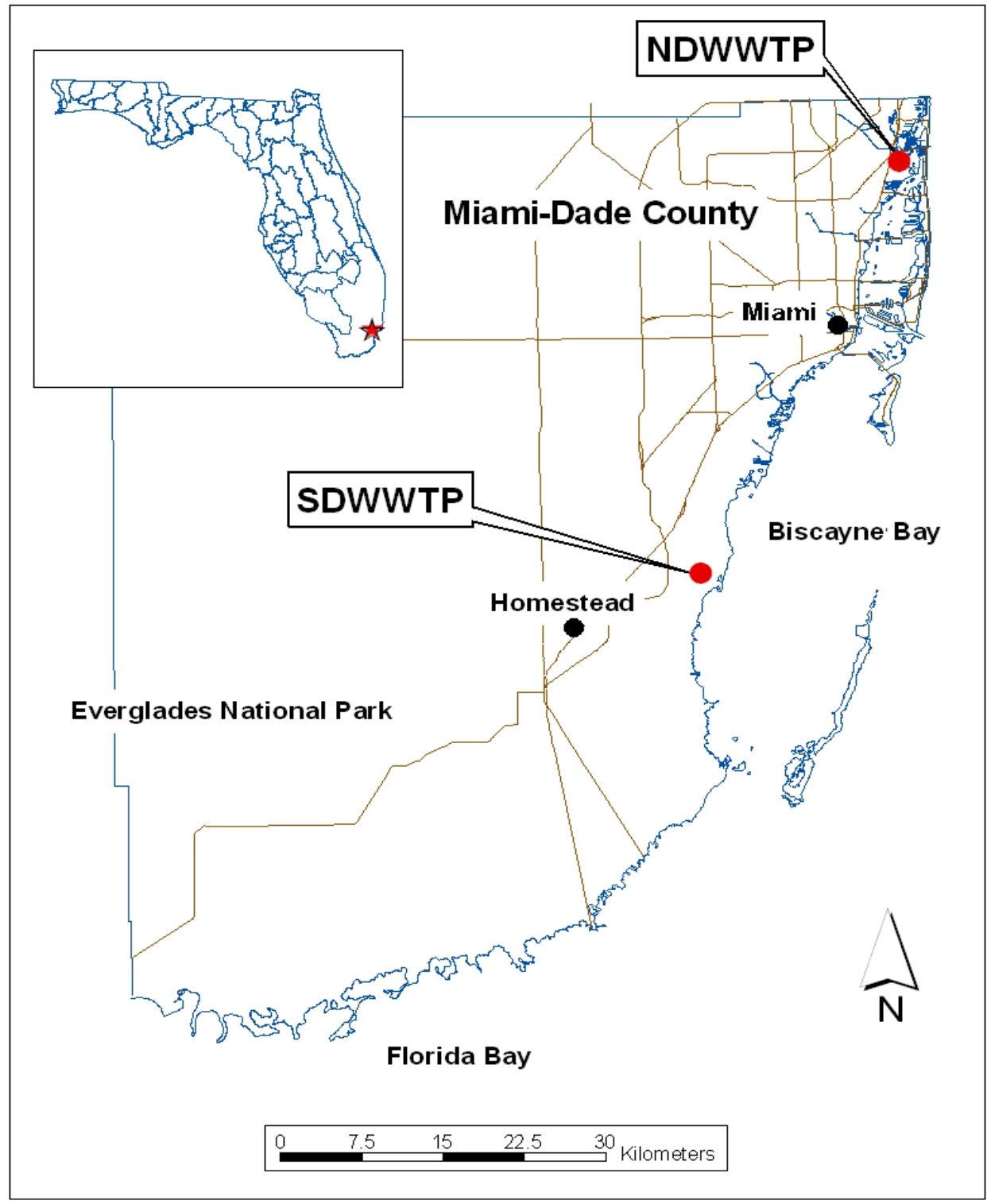

Figure 3.1 Location of the north, south, and the ASR study sites. 


\begin{tabular}{|c|c|c|c|c|c|}
\hline Series & Geologic unit & \multicolumn{2}{|c|}{ Hydrogeologic unit (HU) } & $\begin{array}{l}\text { Approximate } \\
\text { Thickness }\end{array}$ & $\begin{array}{c}\text { Base of } \\
\text { HU }\end{array}$ \\
\hline Holocene and Pleistocene & Various* & \multirow{2}{*}{ 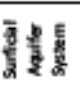 } & Biscayne Aquifer & \multirow{2}{*}{60} & \multirow[b]{2}{*}{60} \\
\hline Pliocene & Tamiami Formation & & Lower Tamiami Aquifer & & \\
\hline \multirow[t]{2}{*}{ Miocene and late Oligocene } & \multirow[t]{2}{*}{ Hawthorn Group } & 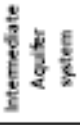 & Confining Unit & 245 & 305 \\
\hline & & \multirow{7}{*}{ 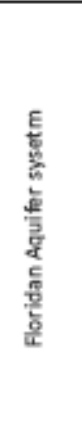 } & Upper Floridan Aquifer (UF) & 30 & 335 \\
\hline Early Oligocene & Suwanee Limestone & & \multirow{2}{*}{ Middle Confining Unit (M1) } & \multirow[b]{2}{*}{125} & \multirow[b]{2}{*}{450} \\
\hline \multirow{5}{*}{ Eocene } & \multirow[b]{3}{*}{ Awon Park Formation } & & & & \\
\hline & & & Avon Park Permeable Zone & 30 & 490 \\
\hline & & & MC2 & 240 & 790 \\
\hline & Oldsmar Formation & & LFA & 125 & 255 \\
\hline & & & $B Z$ & 90 ? & $?$ \\
\hline
\end{tabular}

- includes Miami Limestone, Fort Thompson Formation, Anastatia Formation, Key Largo Limestone

"* meters below land surface

Figure 3.2 Geologic Cross section. 


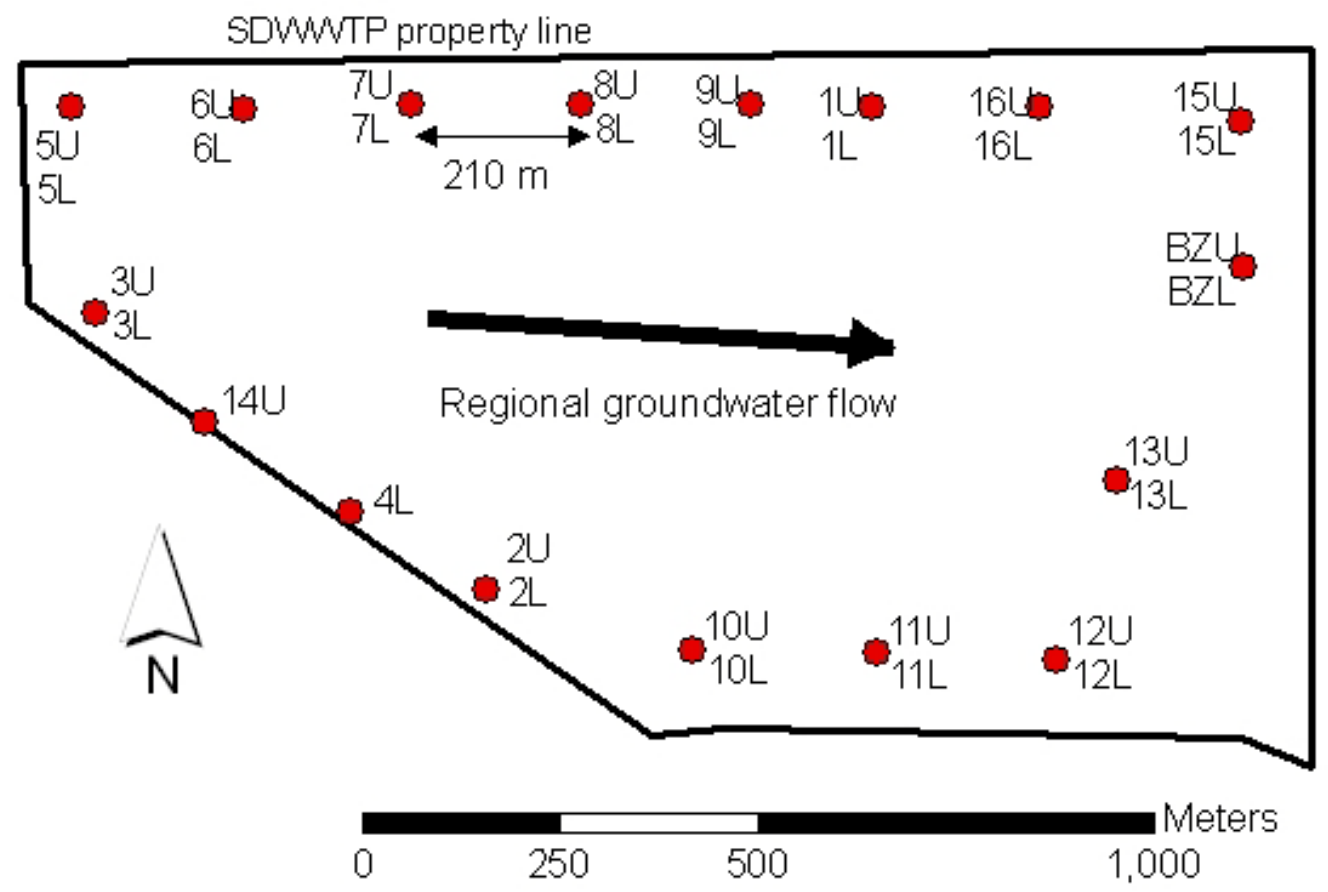

Figure 3.3 Well location at the south site. Each well consists of an upper zone (U) and a lower (L) monitoring zone. Each well is in close proximity to an injection well (which are not shown to retain clarity in figure). 


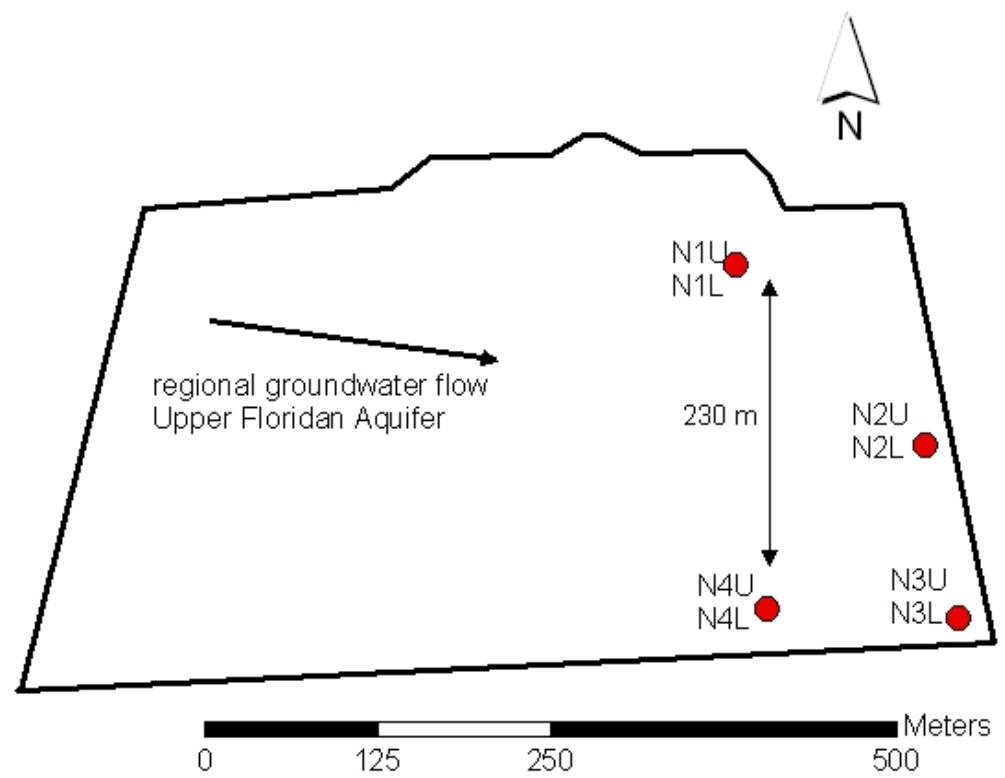

Figure 3.4 Well location at the north site. Each well consists of an upper zone (U) and a lower (L) monitoring zone. Each well is in close proximity to an injection well (which are not shown to retain clarity in figure). 


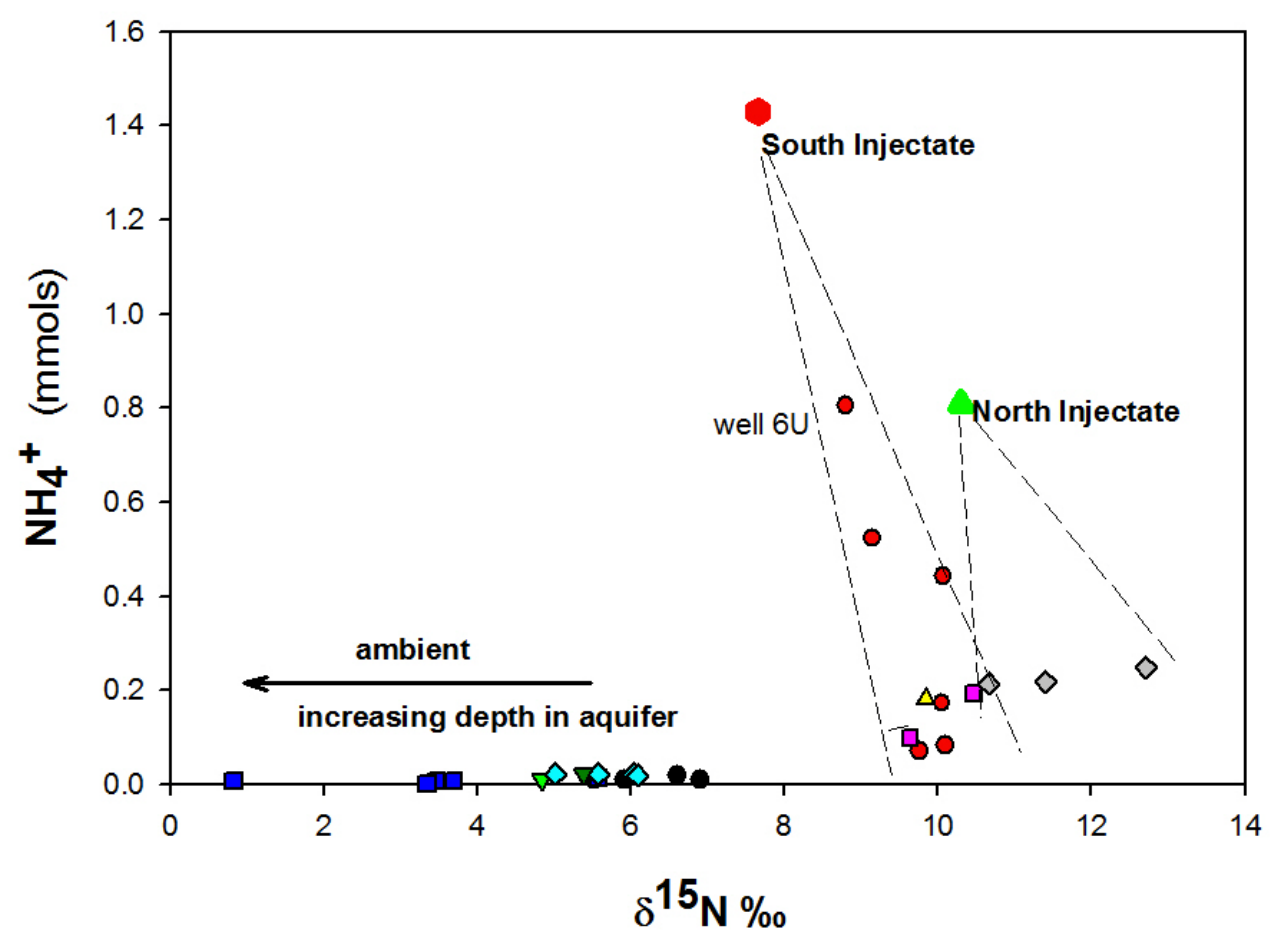

$\begin{array}{ll}- & \text { UFA south } \\ 0 & \text { MC1 South site elevated } \mathrm{NH}_{4}^{+} \\ \nabla & \text { MC1/APPZ south } \\ \Delta & \text { MC1/APPZ South site elevated } \mathrm{NH}_{4}{ }^{+} \\ \square & \text { MC2 south } \\ \square & \text { MC2 South site elevated } \mathrm{NH}_{4}^{+} \\ \diamond & \text { UFA north } \\ \diamond & \text { Lower MC1 North site elevated } \mathrm{NH}_{4}^{+} \\ \nabla & \text { ASR }\end{array}$

Figure $3.5 \mathrm{NH}_{4}^{+}$concentrations versus $\delta^{15} \mathrm{~N}_{-} \mathrm{NH}_{4}{ }^{+} \%$. Ambient $\delta^{15} \mathrm{~N}-\mathrm{NH}_{4}{ }^{+} \%$ values decrease with depth in the aquifer, suggesting different sources of $\mathrm{NH}_{4}{ }^{+}$in different zones in FAS. Wells with elevated $\mathrm{NH}_{4}{ }^{+}$concentrations at south and north sites had increasing $\delta^{15} \mathrm{~N}-\mathrm{NH}_{4}{ }^{+} \%$ value with decreasing $\mathrm{NH}_{4}{ }^{+}$concentrations. 

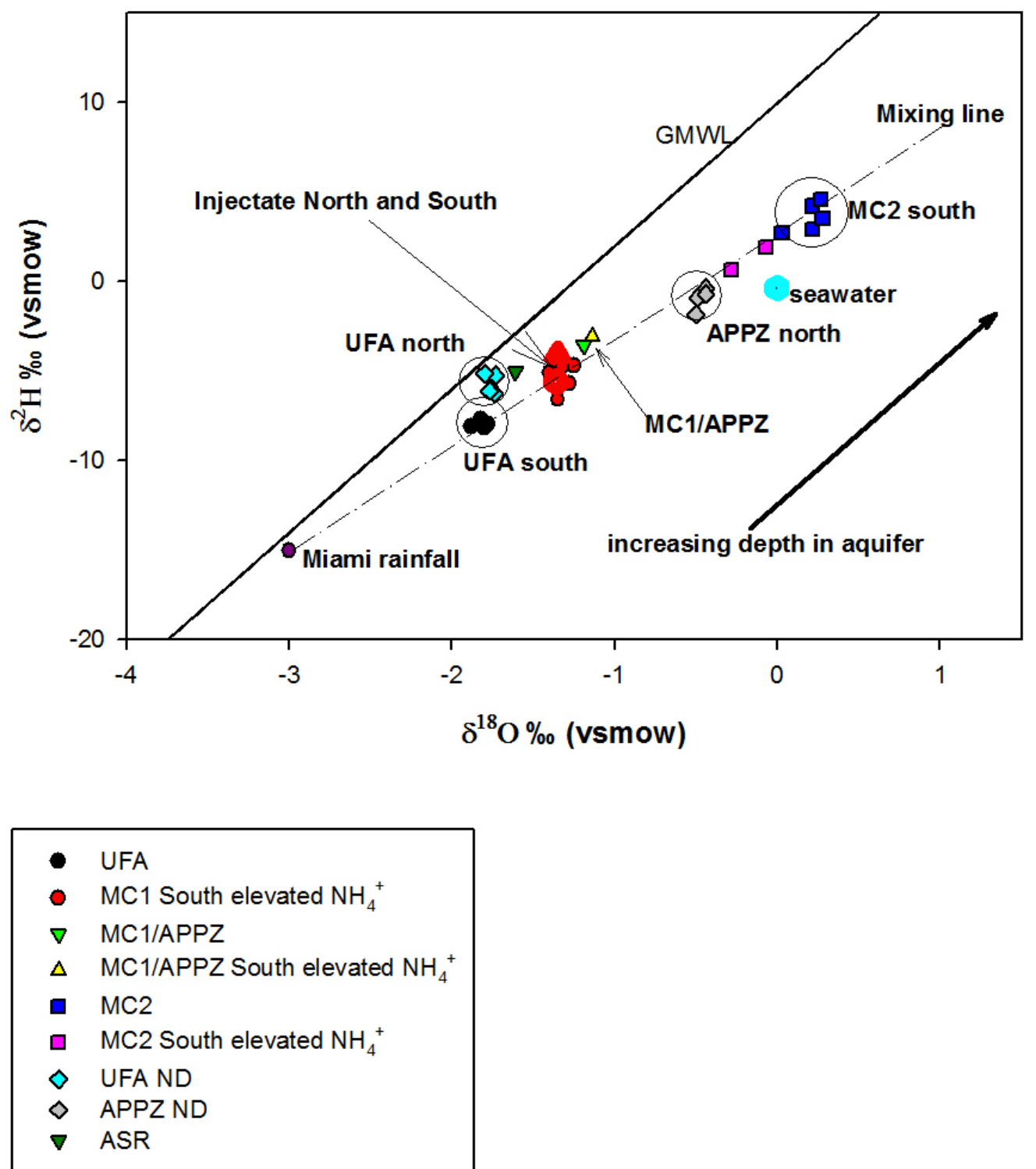

Figure $3.6 \delta^{2} \mathrm{H} \%$ vs $\delta^{18} \mathrm{O} \%$ values. Ambient values cluster according to depth in the aquifer, suggesting little hydrologic connection between monitored zones. Ambient deeper zones plot heavier than seawater; ambient upper zones plot off to the right indicating evaporative meteoric sources. $\mathrm{MCl}$ zones with elevated $\mathrm{NH}_{4}{ }^{+}$concentrations 
at the south site lie along mixing line to injectate values, and do not show any mixing from underlying MC2 zone. 

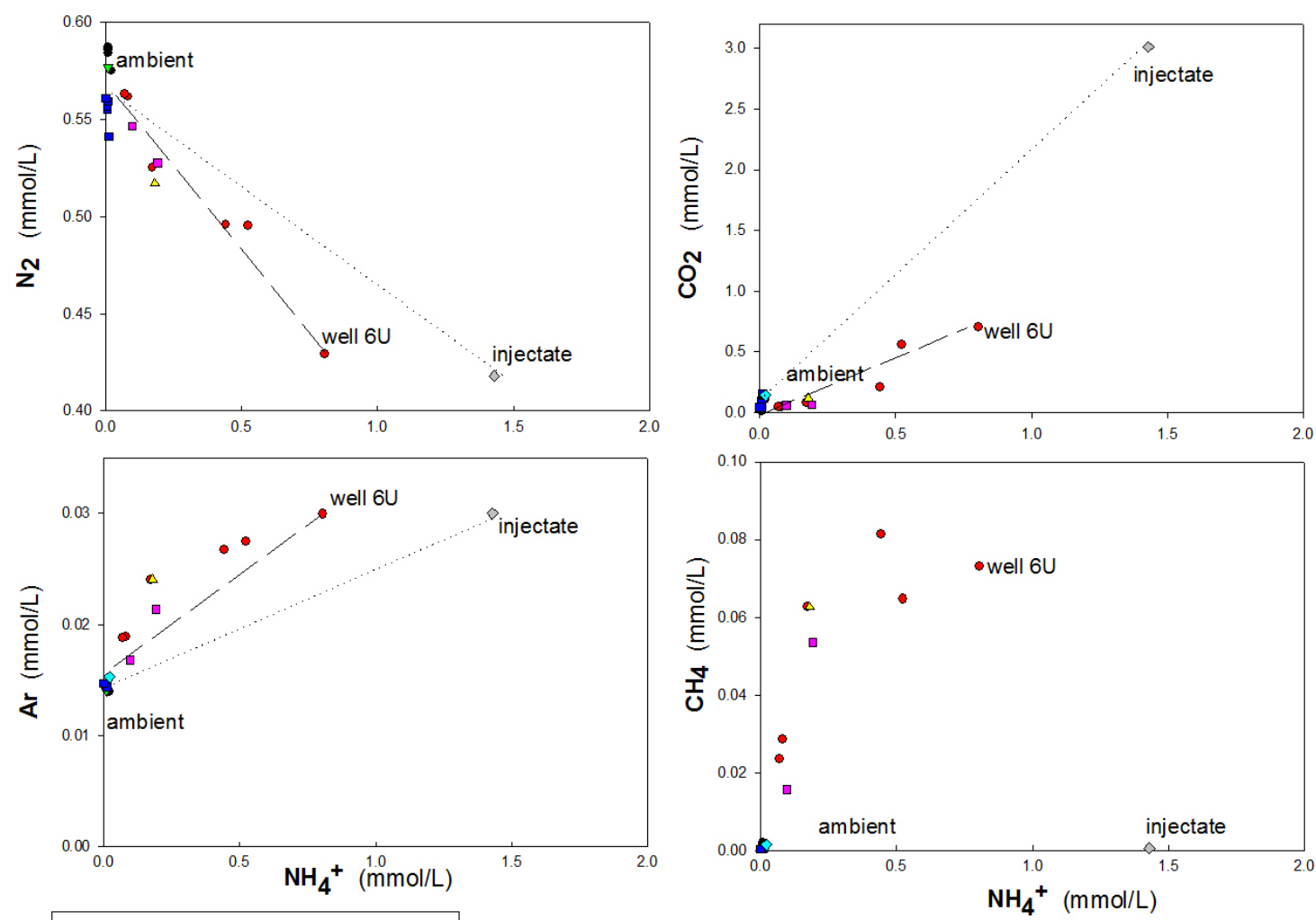

- Ambient UFA

- MC1 South elevated $\mathrm{NH}_{4}{ }^{+}$

$\checkmark$ Ambient MC1/APPZ

$\triangle$ MC1/APPZ South elevated $\mathrm{NH}_{4}{ }^{+}$

- Ambient MC2

- MC2 South elevated $\mathrm{NH}_{4}{ }^{+}$

$\diamond \quad$ ASR

Figure 3.7 Dissolved gas vs. $\mathrm{NH}_{4}^{+}$concentrations. $\mathrm{N}_{2}$ and argon concentrations from the zones with elevated $\mathrm{NH}_{4}^{+}$concentrations reflect the cryogenic treatment process in the injectate, with well $6 \mathrm{U}$ having very similar concentrations of those gases to the injectate. $\mathrm{CO}_{2}$ concentrations in well $6 \mathrm{U}$ show a much quicker decrease than either $\mathrm{N}_{2}$ or argon, and along with the appearance of $\mathrm{CH}_{4}$ in wells with elevated $\mathrm{NH}_{4}^{+}$concentrations, would suggest methanogenic processes. Dotted line on $\mathrm{N}_{2}$ and argon binary plots are mixing line between injectate and ambient concentrations; dashed line is mixing line between well $6 \mathrm{U}$ and ambient concentrations. 

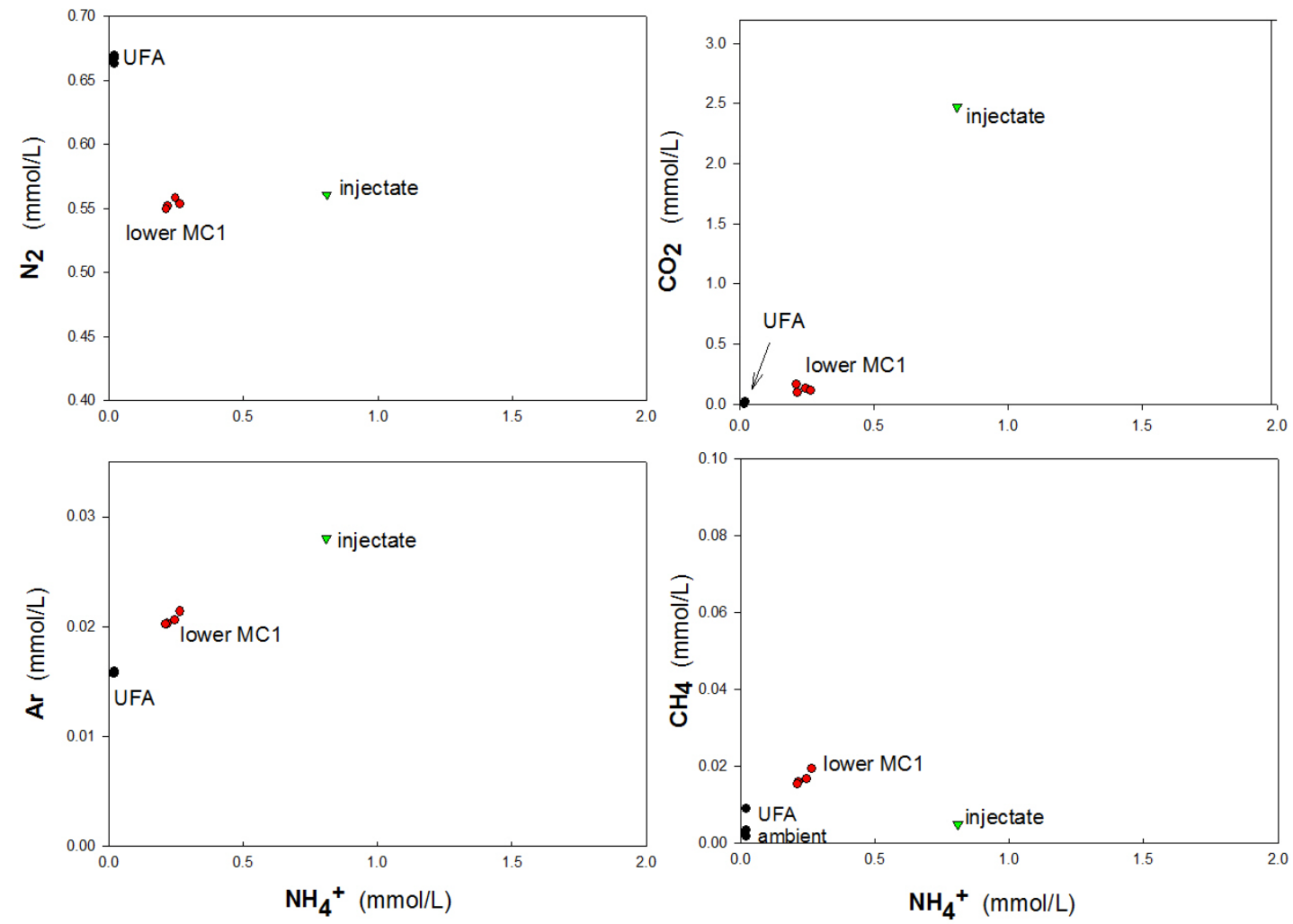

Figure 3.8 Dissolved gas vs. $\mathrm{NH}_{4}^{+}$concentrations at the north site. Although the impact of the cryogenic process is evident in lower MC1 zone, the dissolved gas concentrations lie closer to ambient concentrations. $\mathrm{N}_{2}$ concentrations for lower $\mathrm{MC} 1$ are similar to the $\mathrm{N}_{2}$ concentrations at the ambient MC2 zone at the south site. 

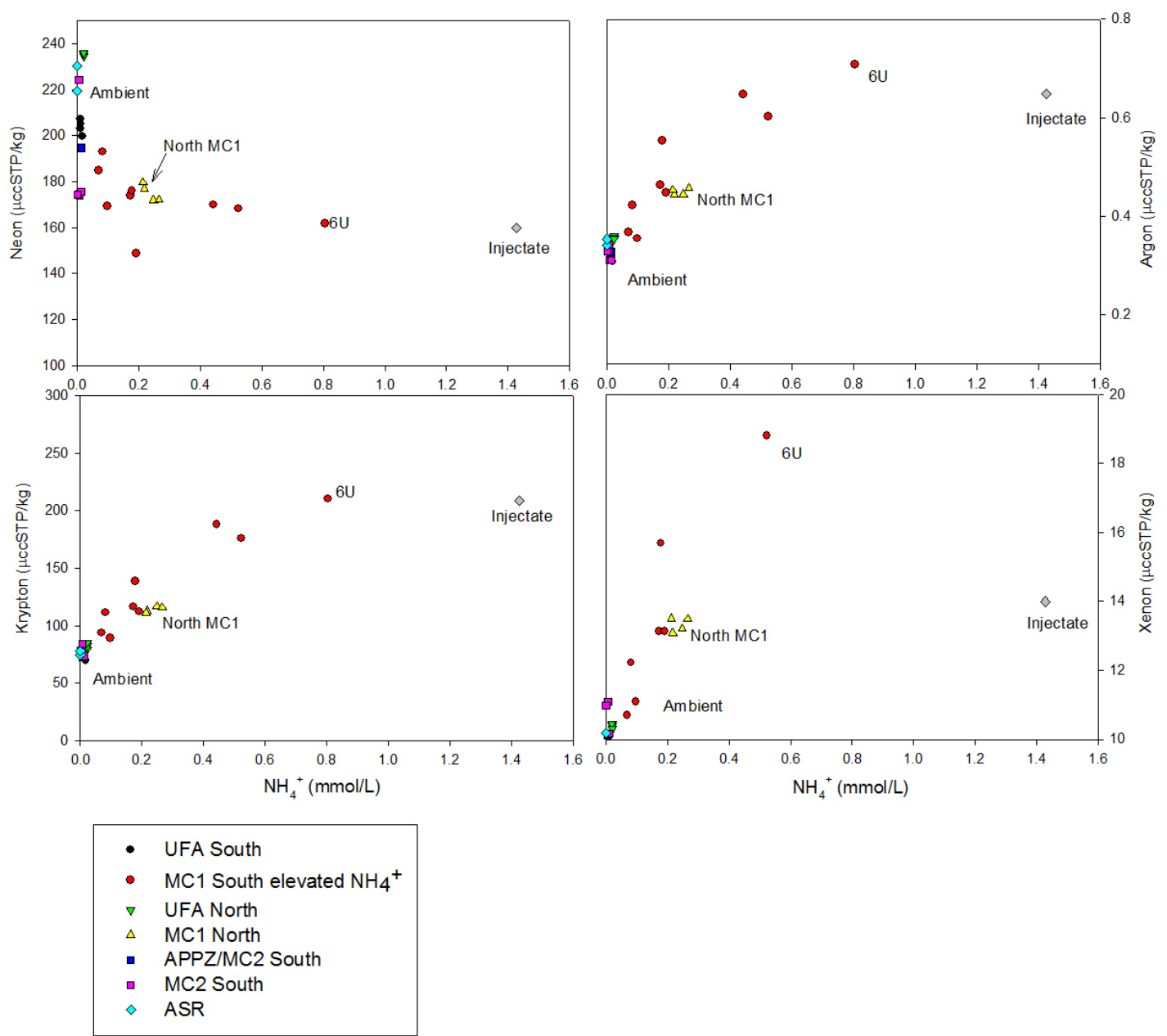

Figure 3.9 Dissolved noble gases vs. $\mathrm{NH}_{4}^{+}$concentrations. Dissolved gas concentrations from zones with elevated $\mathrm{NH}_{4}^{+}$concentrations reflect the cryogenic treatment process in the injectate, with well $6 \mathrm{U}$ having very similar concentrations of those gases to the injectate. Neon, argon and krypton concentrations for well $6 \mathrm{U}$ are very similar to the injectate, however, $\mathrm{NH}_{4}^{+}$concentrations are lower than injectate. Data from the north site (yellow triangles) are plotted to show the little variance between samples. 


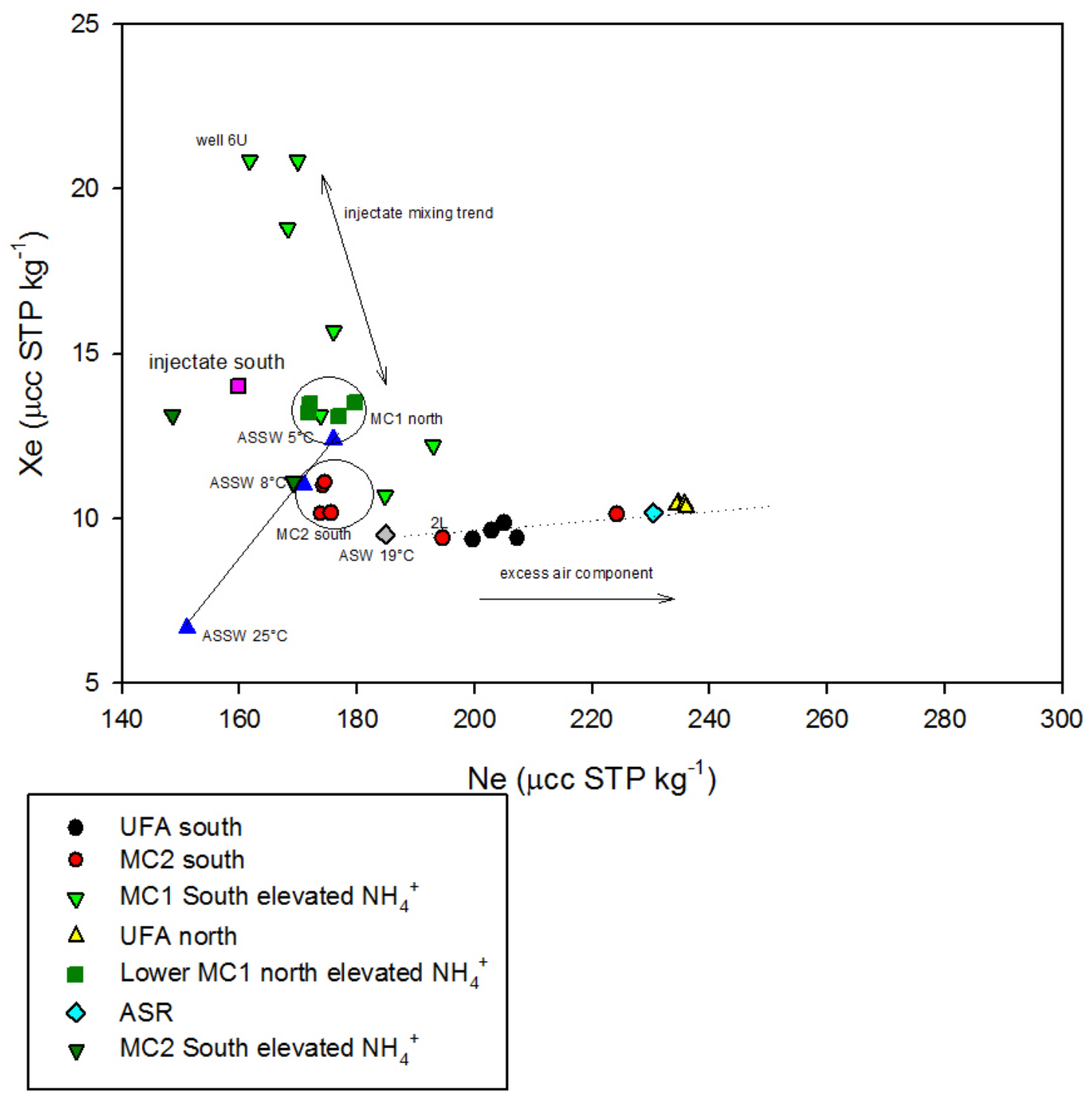

Figure 3.10 Neon and xenon concentrations. ASW: air saturated water; ASSW: air saturated sea water. MC2 ambient plot to the right of ASSW at $8^{\circ} \mathrm{C}$, which would be consistent with Holocene-age recharge from the Florida Straits. Impacted MC1 at the south site shows mixing trend from well $6 \mathrm{U}$ to $\mathrm{ASW}$ equilibrium line. $\mathrm{MC} 1$ from the north site shows little variance between concentrations, and do not show a gradual mixing as seen in MC1 south data. 


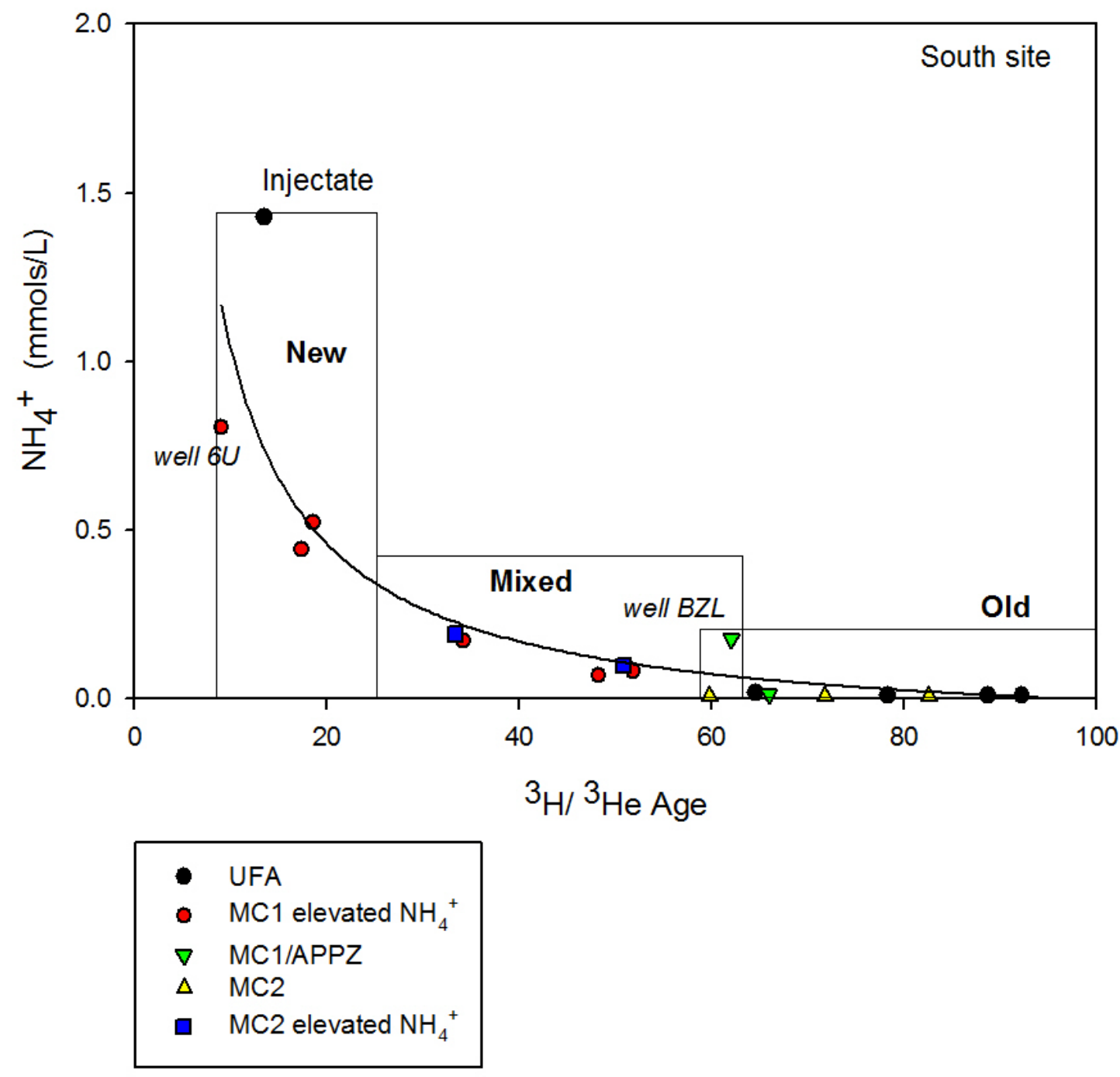

Figure $3.11{ }^{3} \mathrm{H} /{ }^{3} \mathrm{He}$ age vs. $\mathrm{NH}_{4}^{+}$concentrations. Samples grouped into "new" (recent recharge with injectate), "mixed" (mixed between new and old water), and "old" (tritium dead water, recharge prior to initiation of plant operations). Well BZL overlapped between "mixed: and "old", reflecting the injectate plume at BZL a result of an open connection to the BZ present at the commencement of site operations in the early 1980's. 

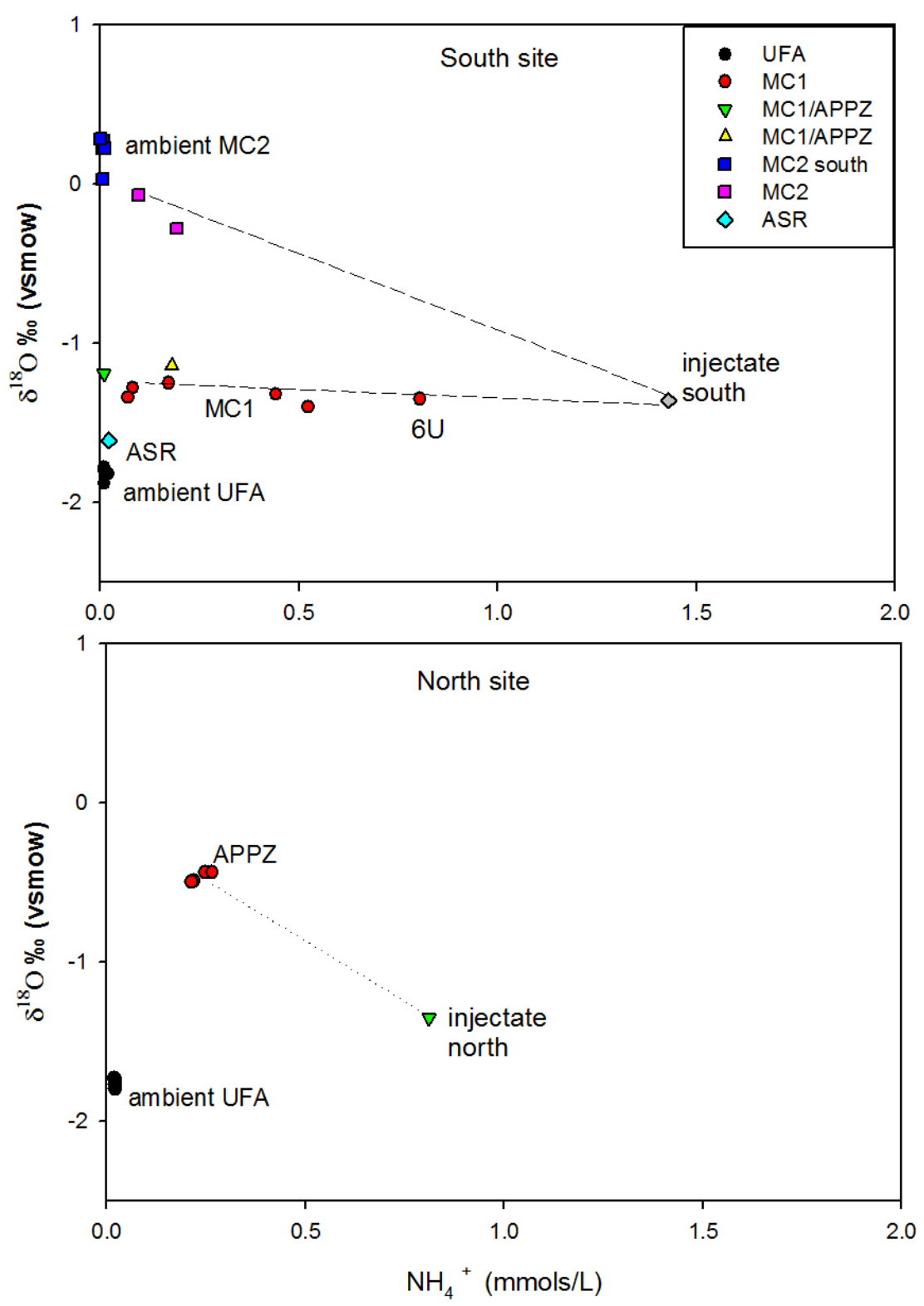

Figure $3.12 \delta^{18} \mathrm{O} \%$ values vs. $\mathrm{NH}_{4}^{+}$concentrations. Zones with elevated $\mathrm{NH}_{4}^{+}$concentration mixing trends trace back to injectate; $\mathrm{MC} 1$ with $\mathrm{NH}_{4}^{+}$concentrations shows no evidence of $\mathrm{MC} 2$ mixing. 


\section{CHAPTER 4 EFFECTS ON CARBONATE EQUILIBRIUM FROM MIXING FRESH WASTWATER IN A DEEP SALINE AQUIFER, SOUTH FLORIDA, U.S.A.}

\subsection{Introduction}

Deep well injection of treated municipal wastewater into non-potable aquifers occurs on a global scale and is most prevalent in developed countries (Saripalli et al., 2000). Deeper aquifers have been used for many decades in Florida, USA, for the disposal of industrial and municipal waste fluids (Meyer 1989a; Meyer 1989b). These deep aquifers tend to be saline, which limits their use as potential potable water supplies, and therefore little research has been conducted regarding the fate and transport of the injectate as there has never been the intention for its recovery (Meyer 1989a; Haberfeld 1991). Miami-Dade County Water and Sewer Department (MDWASD), located in southern Florida, currently disposes 430 million liters per day (MLD) of treated domestic wastewater into a deep saline aquifer at two locations in the county. The treated wastewater (injectate) is injected into the Boulder Zone, a highly transmissive saline zone of the Lower Floridan Aquifer. The Boulder Zone was thought to be hydrologically separated from overlying aquifers by a 335 meter thick confining unit, which would prevent the buoyant transport of the freshwater injectate upwards into overlying aquifers. Ammonia $\left(\mathrm{NH}_{3}\right)$ was detected in 1994 at 442 meter depth in the overlying aquifer at a concentration of $411 \mu \mathrm{mol} / \mathrm{L}$ above reported background levels of $29 \mu \mathrm{mol}$ per liter(BC\&E/CH2MHill 1977). The detection of $\mathrm{NH}_{3}$ in the aquifers above the Boulder Zone has raised doubts regarding the efficacy of the confining unit and the resultant water quality impact to overlying aquifers, as these 
aquifers are used as alternative water supplies via storage of freshwater (ASR) and blending with potable surficial aquifer water.

The mixing of injected freshwater into a deep saline aquifer may geochemically resemble the mixing of a coastal fresh water-seawater mixing zone. The saline-freshwater mixing zone in carbonate aquifers is described as conservative mixing of salinefreshwater endmembers in a closed $\mathrm{CO}_{2}$ system resulting in an area of undersaturation with respect to carbonate minerals (Back et al., 1979; Smart et al., 1988; Stoessell et al., 1989). Carbonate equilibrium in these models is dependent upon the temperature, $\mathrm{pH}$, ionic strength of waters, partial pressure of $\mathrm{CO}_{2}$, and the ion activities of the ions involved, $\mathrm{Ca}^{2+}$ and $\mathrm{HCO}_{3}{ }^{-}$, and changes in the saturation states of carbonate minerals can result when fluids of different chemical composition mix together (Wigley and Plummer, 1976). These changes in carbonate equilibrium in the mixing zones of aquifers can redistribute porosity and permeability (Hanshaw and Back, 1980). Dissolution of carbonates as a result of undersaturated coastal mixing zones have been reported in many locations, including Yucatan Peninsula (Hanshaw and Back, 1980; Back et al., 1986; Stoessell et al., 1989), and Andros Island, Bahamas (Smart et al., 1988, Whitaker and Smart, 1997). This can be a complex geochemical process, and not completely predicted by conservative mixing models. For example, carbonate equilibrium can be affected by stresses on an aquifer such as coastal pumping, as was found in Mallorca, Spain, (Price and Herman, 1991) and Manukan Island near East Malaysia (Aris, et al., 2010). In those locations, pumping of the freshwater aquifer resulted in movement of the mixing zone landward, and an oversaturation of mixing waters with respect to calcite and aragonite 
due to outgassing of $\mathrm{CO}_{2}$ from the water table. Studies of fresh water-saline mixing in the Floridan aquifer in west-central Florida indicated that aquifer waters were oversaturated with respect to calcite, however calcite precipitation was not observed as predicted by the geochemical model (Wicks, et al., 1995).

Geochemical speciation and mole-balance modeling can be used to understand the induced flow and changes in geochemistry in the aquifer as a result of injected fluids (Parkhurst and Petkewich, 2002). In the current study, the mixing of freshwater injectate with native, saline water of the Floridan aquifer on carbonate equilibrium is evaluated. There is strong evidence that injectate has migrated vertically upward into overlaying brackish aquifers, as a result of buoyant flow through the confining units above the Boulder Zone, by natural and/or anthropogenic vertical pathways (MDWASD, 1995; Rust Environmental, 1996; Maliva, et al., 2007; McNeill, 2000; MDWASD, 2005; Starr et al., 2001; King et al., 2009; Dausman et al., 2010; Walsh and Price, 2010). We hypothesize that the mixing of freshwater injectate and deep saline aquifer water (similar to the freshwater-seawater mixing zone) may result in an undersaturation state with respect to calcite, resulting in calcite dissolution and the rearrangement of porosity and permeability possibly enhancing the ability of upward migration and transport of injectate into overlying aquifers over time. The objective of the current study was to determine the geochemical reactions and changes to carbonate equilibrium as a result of the mixing of injectate and native waters in the Floridan aquifer, and to relate the changes in carbonate equilibrium to upward migration and transport of the injectate. The results of the research 
have implications for ongoing and future deep well injection sites in carbonate bearing aquifers.

\subsubsection{Study Area}

The two deep well injection sites operated by MDWASD include the South District Wastewater Treatment Plant (SD) located in southern Miami-Dade County, and the North District Wastewater Treatment Plant (ND) located approximately 44 kilometers to the north (Figure 4.1). The SD is permitted to inject approximately 380 million liters per day (MLD) while the ND is permitted to inject 90 MLD of wastewater. At both sites, the injectate consists of secondarily treated domestic fresh wastewater, that is injected into the Boulder Zone, approximately 900 meters below land surface (bls). The SD operates seventeen injection wells (Figure 4.2), and each injection well has an associated dualzone monitoring well that is designed to monitor the overlying aquifers, with each well constructed to have zones open to two different intervals (see Walsh and Price, 2010, for a full description of the site layout and monitoring well information). The ND operates four injection wells, and four associated dual-zone monitoring wells (Figure 4.3). Elevated $\mathrm{NH}_{4}{ }^{+}$concentrations detected in monitoring wells in the 1990's at both sites were interpreted as evidence of upward injectate migration, and geochemical evidence and numerical and analytical modeling has shown that injectate has possibly migrated to the overlying aquifers, bypassing the underlying confining units in some areas, and in other areas appears to be the result of horizontal advective flow once introduced into a hydrologic zone (MDWASD, 2005; King et al., 2009; Dausman et al., 2010; Walsh and Price, 2010). 
The two study sites are underlain by two carbonate aquifer systems, the Surficial Aquifer System (SAS), and the confined Floridan Aquifer System (FAS), which is composed of 800 meter $(\mathrm{m})$ thick sequences of carbonate and dolomitic limestones, deposited during the Paleocene to the Oligocene epochs (Figure 4.4). The SAS is an unconfined Pleistocene age carbonate sequence that is the source of potable water for south Florida (Fish and Stewart, 1991), with a group of impermeable sediments known as the Hawthorn group providing a $180 \mathrm{~m}$ thick confining unit between the SAS and the Floridan Aquifer System (Figure 4.4). In south Florida the FAS has several recognized major hydrogeologic zones (Reese and Richardson 2008). The Upper Floridan Aquifer (UFA) consists of highly permeable zones (flow zones) interlayered with thicker, lower permeable zones. The Middle Confining Units MC1 and MC2 underlie the UFA, with the two units separated by the Avon Park Permeable zone (APPZ). The Lower Floridan aquifer (LFA) is a thick sequence of permeable layers separated by thick semiconfining units of dolomite and limestone (Miller, 1986). The base of the FAS is marked by the massive impermeable anhydrite beds of the Cedar Keys Formation (Miller, 1986). The base of the LFA in south Florida is approximately $930 \mathrm{~m}$ below land surface (Meyers, 1989a). The SAS in south Florida is used for drinking water and irrigation; the UFA is used for groundwater withdrawals for public drinking water supplies, and also for Aquifer Storage and Recovery (ASR).

\subsection{Methods}

Chloride $\left(\mathrm{Cl}^{-}\right)$data from 1983 through 2008 for the north and south sites were collected from the treatment plants' monthly operating reports (MORs). Summary statistics 
including mean, median, standard deviation, maximum and minimum were applied to the time series data for each well to assess water quality changes over time, and to determine ambient water quality for each of the representative hydrogeologic zones (refer to Walsh and Price, 2010, for a complete description of ambient water quality determination). Residence time of groundwater in the upper FAS in south Florida is thousands of years (Meyer 1989a), and therefore it is assumed that the aquifer matrix and water is in equilibrium and there would be no other cause of large deviations to water quality over time other than migration of injectate. Chloride time series data that showed large variation over time indicate non-equilibrium conditions, and therefore not representative of ambient conditions.

Floridan aquifer water samples were collected from the monitoring wells at the SD and the ND sites during 2006 and 2007 as part of this study and analyzed for major ions $\left(\mathrm{Ca}^{2+}, \mathrm{K}^{+}, \mathrm{Na}^{+}, \mathrm{Mg}^{2+}, \mathrm{Cl}^{-}, \mathrm{SO}_{4}{ }^{2-} \mathrm{HCO}_{3}^{-}, \mathrm{CO}_{2}{ }^{-}, \mathrm{Br}\right)$, silica and nitrogen species. During the study, many of the dual zone monitoring wells had developed corrosive holes in the casing, and were no longer suitable for monitoring purposes, therefore a total of twenty monitoring wells were used at the SD, and eight wells at the North District (Table 4.1). Water quality samples were collected from the twenty monitoring wells at the SD from wells representing the UFA, the MC1, the APPZ, and the Middle Confining Unit Two. At the ND, samples were collected from four monitoring wells representing the lower UFA/upper MC1 (hereafter referred to the UFA), and four wells in the lower MC1/APPZ (hereafter referred to the APPZ). Temperature, $\mathrm{pH}$, dissolved oxygen, and specific conductance were taken from water samples in the field using a YSI ${ }^{\mathrm{TM}} 556$ MPS, with 
instrumentation calibrated prior to each sampling event. The monitoring wells were purged for at least 24 hours prior to the sampling events to ensure at least three well volumes were evacuated prior to sampling. Samples were collected through a closed system using a low flow cell and tygon tubing through a disposable, high capacity 0.45 $\mu \mathrm{M}$ in-line filter. Water samples were analyzed for the major anions $\mathrm{Br}^{-}, \mathrm{Cl}^{-}$, and $\mathrm{SO}_{4}{ }^{2-}$ on a DIONEX ${ }^{\circledR}$ ion chromatography system, and the major cations $\left(\mathrm{Ca}^{2+}, \mathrm{Mg}^{2+}, \mathrm{K}^{+}\right.$, and $\mathrm{Na}^{+}$) were analyzed by inductively coupled plasma (ICP). The ions $\mathrm{HCO}_{3}{ }^{-}$and $\mathrm{CO}_{2}{ }^{-}$ were analyzed via manual titration using a standard acid $\left(\mathrm{HCl}\right.$ or $\left.\mathrm{H}_{2} \mathrm{SO}_{4}\right)$ and calculated using the mass balance speciation method. A $\mathrm{LACHAT}^{\circledR}$ analyzer 800 was used to analyze for $\mathrm{NH}_{3}$, with $\mathrm{NH}_{4}{ }^{+}$calculated based on $\mathrm{pH}$ and temperature of the sample using the $\mathrm{NH}_{3}$ result (Stumm and Morgan 1996).

Samples were collected again in February 2008 for analysis of carbon dioxide $\left(\mathrm{CO}_{2}\right)$, methane $\left(\mathrm{CH}_{4}\right)$, and dissolved noble gases (helium, neon, argon, krypton and xenon). Samples for dissolved noble gases were collected in copper tubes that were crimp-sealed while groundwater was flowing through the tube. Dissolved gas samples were collected in serum bottles preserved with potassium hydroxide. Samples were analyzed for the dissolved gases of $\mathrm{Ar}, \mathrm{CO}_{2}$ and $\mathrm{CH}_{4}$ by gas chromatograph on low pressure headspace at the U.S. Geological Survey (USGS) Dissolved Gas Laboratory (Weiss, 1970; Weiss, 1974; Wiesenburg et. al., 1979).

Binary mixing models (BMM) were developed using $\mathrm{Cl}^{-}, \mathrm{Br}^{-}, \mathrm{NH}_{4}{ }^{+}$and $\mathrm{Ar}$ data of the ambient and injectate water quality as the two endmembers for each zone at the SD and the ND, assuming these parameters were nonreactive with either the aquifer matrix or 
groundwater, and therefore conservative. Water quality data from the December 2006 and 2007 sampling events from the SD wells $9 \mathrm{U}$ for the MC1 zone, and well $1 \mathrm{~L}$ from the MC2 zone were used to represent the BMM endmember ambient water quality data. Average water quality data was used for the injectate endmember, due to its seasonal variability (Walsh and Price, 2010). During the 2006 and 2007 sampling events, the APPZ wells at the ND had elevated $\mathrm{NH}_{4}{ }^{+}$concentrations, indicative of the presence of injectate in the aquifer, therefore pre-injection historical data from well N1L was used for the $\mathrm{Cl}^{-}$and $\mathrm{NH}_{4}{ }^{+}$water quality endmember in the Avon Park Permeable Zone. The fraction of injectate $\left(\mathrm{f}_{\text {inj }}\right)$ from each well exhibiting elevated $\mathrm{NH}_{4}{ }^{+}$concentrations was calculated derived from the mass balance equation (Plummer and Back, 1980):

$f_{\text {amb }}=\left(x_{i n j}-x_{\text {sample }}\right) /\left(x_{i n j}-x_{\text {amb }}\right)$

$f_{i n j}=1-f_{a m b}$

where $f_{\text {amb }}$ was the fraction of ambient water in the mixture, $x_{\text {inj }}$ was the concentration of the injectate endmember, $\mathrm{x}_{\text {sample }}$ was the concentration of the sample, $\mathrm{x}_{\mathrm{amb}}$ was the concentration of the ambient endmember, and $\mathrm{f}_{\mathrm{inj}}$ was the fraction of injectate in the mixture. Results for $\mathrm{Cl}^{-}, \mathrm{Br}^{-}$and $\mathrm{NH}_{4}{ }^{+} \mathrm{BMMs}$ were then compared to one another. The geochemical model PHREEQC (Parkhurst and Appelo, 1999) was used to calculate the ion speciation of the water samples and the saturation indices of calcite, dolomite and aragonite. Saturation indices were calculated as the log of the ratio of the ion-activity 
product (IAP) of the mineral in mixtures divided by the equilibrium constant (K) of that mineral (Langmuir, 1971; Plummer, 1975):

$S I_{\text {mineral }}=\log I A P_{\text {min eral }} / K_{\text {min eral }}$

PHREEQC uses ion-association and Debye Hückel expressions to account for the nonideality of aqueous solutions, and through the use of an ionic-strength term in the Debye Hückel expression. These terms were fitted for the major ions using the $\mathrm{Cl}^{-}$mean-salt activity-coefficient data (Truesdell and Jones, 1974, Parkhurst and Appelo, 1999). The FAS was assumed to be closed with respect to $\mathrm{CO}_{2}$, a reasonable assumption given that the Floridan aquifer is a deep, confined aquifer. The $\mathrm{CO}_{2}$ partial pressures $\left(\mathrm{P}_{\mathrm{CO} 2}\right)$ were calculated based on the $\mathrm{CO}_{2}$ concentrations of the February 2008 sampling events using a Henry's constant adjusted for the temperature of the water sample when collected according to Henry's Law:

$S_{i}=k_{i}^{*} P_{i}$

where $S_{i}$ was the solubility of gas $i, k_{i}$ was Henry's Constant for gas $i$, and $P_{i}$ was the partial pressure of gas $i$. Major ion concentrations and field parameters for each sample were input into PHREEQC for initial solution speciation, and then each solution was equilibrated to the observed $\mathrm{P}_{\mathrm{CO} 2}$ values. Samples with a mineral saturation index of $0 \pm 0.5$ were considered to be at equilibrium for that mineral. A positive SI $(>0.05)$ indicated supersaturated conditions for the respective mineral, and would suggest mineral 
precipitation. A negative value $(<0.05)$ indicated undersaturated conditions for the respective mineral, and would suggest mineral dissolution.

Chemical composition and saturation indices were calculated in PHREEQC for the twomember mixing solutions for each hydrogeologic zone at the SD (9U and injectate for the $\mathrm{MC} 1 ; 1 \mathrm{~L}$ and injectate for the MC2), and the APPZ zone at the ND, using injectate fractions ranging from $f_{\text {inj }}=0$ (representing pure ambient water) to $f_{\text {inj }}=1$ (representing pure injectate water). Saturation indices calculated for the $9 \mathrm{U} /$ injectate and $1 \mathrm{~L} /$ injectate (SD), and N1L/injectate (ND) mixing solutions were plotted to develop the two-member mixture SI curves for calcite, dolomite and aragonite. Saturation indices calculated for samples with elevated $\mathrm{NH}_{4}{ }^{+}$concentrations in the MC1 and MC2 zones at the SD (samples 10U, 13U, 15U, 16U, 14U and 6U for the MC1; 10L, 13L and 12L for the MC2) were then compared to the BMM $\mathrm{f}_{\text {inj }}$ for each of the indicated samples, and compared to the two-member mixture saturation indices. The predicted species concentrations were compared to observed concentrations. The same method was used for ND samples in the Avon Park Permeable Zone.

\subsection{Results}

\subsubsection{Binary mixing model results}

The fraction of injectate determined from the binary mixing models for each of the wells with elevated $\mathrm{NH}_{4}{ }^{+}$concentrations at the SD were similar for both the 2006 and 2007 samplings (Figure 4.5). The SD well $6 \mathrm{U}$ (well with highest $\mathrm{NH}_{4}{ }^{+}$concentration) had a mixing fraction $\left(f_{\text {inj }}\right)$ of 0.6 and 0.7 for the month of December in years 2006 and 2007, 
respectively. Well $14 \mathrm{U}$ had a $0.3 \mathrm{f}_{\text {inj }}$ and 0.5 for the month of December in years 2006 and 2007, respectively. The BMM results for well $16 \mathrm{U}$ were $0.1 \mathrm{f}_{\text {inj }}$ for December in both years. Results for wells with lower $\mathrm{NH}_{4}{ }^{+}$concentrations ranged from less than 0.1 to below 0 fraction injectate. The $\mathrm{BMM}$ for $\mathrm{Cl}^{-}$and $\mathrm{Br}^{-}$had very similar results for December both years modeled. Wells with lower $\mathrm{NH}_{4}{ }^{+}$concentrations had an $\mathrm{NH}_{4}{ }^{+}$ BMM slightly higher $f_{\text {inj }}$ for Dec 2006 (Figure 4.5), but results were very similar to the $\mathrm{Cl}^{-}$and $\mathrm{Br}^{-} \mathrm{BMM}$ for the elevated $\mathrm{NH}_{4}{ }^{+}$concentrations wells (wells $14 \mathrm{U}$ and $6 \mathrm{U}$ ). The $\mathrm{NH}_{4}{ }^{+}$BMM results for the December 2007 data had similar $\mathrm{f}_{\text {inj }}$ values for all wells, with the exception of well 16U, which varied for all 3 binary mixing models (Figure 4.5).

The $f_{\text {inj }}$ results for the MC2 wells at the SD were the same for both 2006 and 2007. Results were very similar for the $\mathrm{Cl}^{-}$and $\mathrm{Br}^{-}$models, with the well with the highest $\mathrm{NH}_{4}{ }^{+}$ concentration (well 12L) at $0.9 \mathrm{f}_{\text {inj, }}$, and the well with the lowest $\mathrm{NH}_{4}{ }^{+}$(well 13L) concentration at $0.1 \mathrm{f}_{\text {inj }}$ (Figure 4.6). The $\mathrm{NH}_{4}{ }^{+} \mathrm{BMM}$ was similar to the $\mathrm{Cl}^{-}$and $\mathrm{Br}^{-}$ models for well 13L, and but had a lower $\mathrm{f}_{\text {inj }}$ for the wells with higher $\mathrm{NH}_{4}{ }^{+}$ concentrations. Results for the BMMs at the ND (Figure 4.6) were also very similar for the December 2006 and December 2007 data. The $\mathrm{Cl}^{-}$and $\mathrm{Br}^{-}$models had $\mathrm{f}_{\text {inj }}$ for the ND MC1 wells close to $0.1 \mathrm{f}_{\text {inj }}$, with $\mathrm{NH}_{4}{ }^{+}$BMM $\mathrm{f}_{\text {inj }}$ modeled a slightly higher (Figure 4.6).

\subsubsection{Carbonate mineral saturation indices results}

Injectate at both the SD and the ND was undersaturated with respect to calcite, dolomite and aragonite (Table 4.2). Samples from the UFA at both sites ranged from slightly undersaturated to oversaturated with respect to calcite and aragonite. Wells in the MC1 at the SD with a higher $f_{\text {inj }}$ (wells $14 \mathrm{U}$ and $6 \mathrm{U}$ ) were near equilibrium or slightly 
undersaturated; wells with lower $f_{\text {inj }}$ were oversaturated with respect to calcite and aragonite (Table 4.2). Samples from the MC2 wells were oversaturated with respect to calcite and aragonite (Table 4.2), with the exception of well 12L (highest $\mathrm{NH}_{4}{ }^{+}$ concentration in the MC2), which was undersaturated with respect to calcite and aragonite. The ND APPZ had saturation indices with respect to calcite and aragonite mostly oversaturated. Dolomite was oversaturated for all wells, with the exception of well 4L, and wells with the highest $\mathrm{NH}_{4}{ }^{+}$concentration (6U and 12L). No pattern was observed for the calcite and aragonite saturation indices, other than decreasing saturation indices for the $\mathrm{MC} 1$ wells at the $\mathrm{SD}$ with increasing $\mathrm{NH}_{4}{ }^{+}$concentrations (Figure 4.7). Saturation indices for calcite were calculated for time series data for well $6 \mathrm{U}$ at the SD in an attempt to detect temporal changes, but no significant changes in time were observed.

Saturation indices for calcite, aragonite and dolomite were calculated in PHREEQC for two endmember solution mixtures with a fraction of injectate ranging from $\mathrm{f}_{\text {inj }}=0$ to $f_{\text {inj }}=1$, and then plotted for the 9U/Injectate solution mixture fractions as a curve (Figure 4.8). As expected, the solution mixtures became increasing undersaturated with increasing injectate fraction. The calculated SIs for calcite, dolomite and aragonite for wells with elevated $\mathrm{NH}_{4}{ }^{+}$concentrations were higher than predicted by the mixing curve for both the SD MC1 and MC2 zones (Figures 4.8 and 4.9). A comparison of observed $\mathrm{P}_{\mathrm{CO} 2}$ values to predicted $\mathrm{P}_{\mathrm{CO} 2}$ for the ambient/injectate solution mixture fractions indicated wells with elevated $\mathrm{NH}_{4}{ }^{+}$concentrations were depleted with respect to $\mathrm{CO}_{2}$ for both the MC1 and Middle Confining Unit Two (Figure 4.10). 


\subsection{Discussion}

\subsubsection{Binary mixing models results}

Large deviations between the $\mathrm{Cl}^{-}$and $\mathrm{Br}^{-}$models may indicate the model parameters are not conservative (Davis et al., 1998), however as no large deviations were observed in the $\mathrm{Cl}^{-}$and $\mathrm{Br}^{-} \mathrm{BMMs}$, the assumption of these being conservative tracers is supported. Wells with low $\mathrm{NH}_{4}{ }^{+}$concentrations for the December 2006 sampling event modeled with a negative injectate fraction, and this is probably due to slight variations of water quality in the wells, however both $\mathrm{Cl}^{-}$and $\mathrm{Br}^{-}$model results were similar (Figure 4.5). The three BMMs for well $6 \mathrm{U}$ (the well with the highest $\mathrm{NH}_{4}{ }^{+}$concentration) plotted reasonably close to one another, and that the $\mathrm{NH}_{4}{ }^{+} \mathrm{BMM}$ model results were similar to the $\mathrm{Cl}^{-}$and $\mathrm{Br}^{-} \mathrm{BMMs}$ would suggest the that $\mathrm{NH}_{4}{ }^{+}$behaves conservative once introduced into the MC1 zone of the aquifer. Prior $\delta^{15} \mathrm{~N}_{-} \mathrm{NH}_{4}{ }^{+}$work analyzed for the sites indicated $\mathrm{NH}_{4}{ }^{+}$fractionation was observed in wells with elevated $\mathrm{NH}_{4}{ }^{+}$concentrations, which was interpreted that there may be some $\mathrm{NH}_{4}{ }^{+}$loss in the aquifer (Walsh and Price, in review), and that the reactive loss of $\mathrm{NH}_{4}{ }^{+}$appeared to be minimal. If there was significant loss of $\mathrm{NH}_{4}{ }^{+}$, the $\mathrm{NH}_{4}{ }^{+} \mathrm{BMM}$ would underestimate the $\mathrm{f}_{\text {inj }}$, compared to the $\mathrm{Cl}^{-}$ and $\mathrm{Br}^{-} \mathrm{BMMs}$, which is not seen (Figure 4.5). The BMMs results suggest that loss of $\mathrm{NH}_{4}{ }^{+}$is minor compared to the concentrations found in the aquifer. The BMM for $\mathrm{NH}_{4}{ }^{+}$ plots above the $\mathrm{Cl}^{-} \mathrm{BMM}$ for the APPZ at the ND (Figure 4.6). The SD BMMs for $\mathrm{Cl}^{-}$ and $\mathrm{Br}^{-}$for the lower MC2 zone, are nearly identical (Figure 4.6), with the $\mathrm{NH}_{4}{ }^{+} \mathrm{BMM}$ plotting slightly below the two, which may suggest minor reactive $\mathrm{NH}_{4}{ }^{+}$loss, but still negligible compared to overall $\mathrm{NH}_{4}^{+}$concentrations. 
Argon concentration results for the February 2008 dissolved gas sampling event show an estimated higher $\mathrm{f}_{\text {inj }}$ for wells with increasing $\mathrm{NH}_{4}{ }^{+}$concentration (6U, 14U, 16U and $13 \mathrm{U}$ ), and well $6 \mathrm{U}$ estimated a $\mathrm{f}_{\text {inj }}$ of 1.0 for the argon binary mixing model (Figure 4.5 ). Argon is a product of the oxygen cryogenic treatment in the injectate at both sites; injectate is enriched in $\mathrm{CO}_{2}$ and the heavier noble gases, argon, krypton and xenon, and depleted in the lighter gases (Walsh and Price, in review). For the $\mathrm{Cl}^{-}$and $\mathrm{Br}^{-} \mathrm{BMM}$ the average concentrations of injectate were used, as injectate concentrations of $\mathrm{NH}_{4}{ }^{+}$are highly seasonal (Walsh and Price, 2010), however dissolved gas data from only one sampling event were available. Dissolved gas concentrations from this one sampling event may not represent conditions over time.

\subsection{2 $\mathrm{P}_{\mathrm{CO} 2}$ and carbonate equilibrium}

Carbonate equilibrium is highly sensitive to $\mathrm{P}_{\mathrm{CO} 2}$, temperature, ionic strength of the endmembers, and $\mathrm{pH}$ of the solutions prior to mixing (Plummer, 1975; Wigley and Plummer, 1976). Temperature and $\mathrm{pH}$ variations in the solution endmembers were small (Table 4.1), and not within the variance range that would significantly affect saturation index (Plummer, 1975). No trend in $\mathrm{SI}_{\text {calcite }}$ could be discerned based on sample depth (Figure 4.7), but wells with increasing $\mathrm{NH}_{4}{ }^{+}$concentrations became less oversaturated for both the $\mathrm{MC} 1$ and $\mathrm{MC} 2$ at the $\mathrm{SD}$ and well $6 \mathrm{U}$ (highest $\mathrm{NH}_{4}{ }^{+}$concentration) was close to equilibrium (Figure 4.7). Wells with low $\mathrm{NH}_{4}^{+}$concentrations in all hydrogeologic zones in the FAS were mostly oversaturated with respect to calcite, dolomite and aragonite (Table 4.2), similar to results found in other Floridan Aquifer studies (Back and Hanshaw, 1970; Plummer, 1977; Sprinkle, 1989; Budd, et al., 1993; Wicks et al., 1995). 
All wells were undersaturated with respect to gypsum, similar to other Floridan aquifer results (Wicks, et al., 1995).

\subsubsection{Injectate excess $\mathrm{CO}_{2}$ and methanogenesis in carbonate equilibrium}

Wells with elevated $\mathrm{NH}_{4}{ }^{+}$concentrations in the $\mathrm{MC} 1$ at the $\mathrm{SD}$ were close to equilibrium with respect to calcite, and were more oversaturated than predicted by conservative mixing (Figure 4.8). These elevated $\mathrm{NH}_{4}{ }^{+}$concentration wells had lower $\mathrm{P}_{\mathrm{CO} 2}$ than predicted by conservative mixing (Figure 4.10). This depletion in $\mathrm{CO}_{2}$ in wells with elevated $\mathrm{NH}_{4}{ }^{+}$concentrations is explained by the injectate cryogenic treatment process at both sites. Injectate water is enriched with $\mathrm{CO}_{2}$ as a result of the cryogenic treatment (Walsh and Price, in review) however, it is depleted in methane (as is ambient groundwater in the FAS), as methane is collected at the treatment plants and used for power generation. Well $6 \mathrm{U}$ (highest $\mathrm{NH}_{4}{ }^{+}$concentration) had very similar concentrations of argon and $\mathrm{N}_{2}$ compared to injectate concentrations (Table 4.1), however it was depleted in $\mathrm{CO}_{2}$ concentration compared to injectate. Elevated concentrations of methane were observed in wells with elevated $\mathrm{NH}_{4}{ }^{+}$concentrations (Walsh and Price, in review). Methane and $\mathrm{CO}_{2}$ show an inverse relationship in SD water samples (Figure 4.11) as would be expected by methanogenesis (Bates et al., 2011) as described by the following equation:

$\mathrm{CO}_{2}+4 \mathrm{H}_{2} \rightarrow \mathrm{CH}_{4}+2 \mathrm{H}_{2} \mathrm{O}$

The calcite saturation indices for well $6 \mathrm{U}$ and 12L were recalculated in PHREEQC using injectate $\mathrm{CO}_{2}$ concentrations (assuming no reactive loss of $\mathrm{CO}_{2}$ through methanogenesis, 
and based on the argon concentrations in these wells being very similar to injectate concentrations). The recalculated calcite saturation indices fell closer to the conservative mixing curve (Figure 4.8). Bacterial processes have been reported for other aquifers whereby the production of additional $\mathrm{CO}_{2}$ by the oxidation of organic material resulted in enhanced calcite undersaturation (Whitaker and Smart, 1997), however, in the current study bacterial processes depleted $\mathrm{CO}_{2}$ and diminished calcite undersaturation.

Injectate water is highly undersaturated with respect to calcite, dolomite and aragonite, and once introduced into the saline Boulder Zone, geochemical modeling predicts porosity enhancement through dissolution of these minerals. The corrosive water may contribute to enlargement of migration pathways, allowing for greater upward fluid flow as a result of buoyancy differences between native waters and injectate. Geochemical modeling predicts dissolution should persist with aquifer water that contains greater than $2 \%$ injectate (Figure 4.8), which would include most MC1 wells at the South site. However, observed results show only well water containing greater than $50 \%$ injectate as close to undersaturated. The results suggest $\mathrm{CO}_{2}$ methanogenic uptake and diminished calcite undersaturation as a result of decreasing $\mathrm{CO}_{2}$ concentrations along the injectate vertical flow paths to the overlying aquifers. Once introduced into the overlying aquifers, injectate continues to mix along flow paths within the aquifer. The mixed waters become depleted in excess $\mathrm{CO}_{2}$ as a result of methanogenesis, and become oversaturated with respect to calcite, aragonite and dolomite, suggesting precipitation of these minerals. The oversaturation of carbonate minerals in the current study is similar to other findings for the confined Floridan aquifer, however in those studies the predicted precipitation of 
minerals was not observed in thin section (Budd et al., 1993; Wicks et al., 1995).

Analysis of core samples from the two sites in this study was not part of this research, so mineral precipitation could not be determined, however it is reasonable to assume there would be results similar to the other Floridan aquifer studies.

\subsubsection{Evidence of Confinement Bypass Pathways}

Confinement bypass features are vertical pathways that allow upward migration of injectate to the APPZ and MC1 bypassing the lower Floridan confining units and the Middle Confining Unit Two. These features may be the result of improper construction of the injection wells (i.e. slipped casings or drifting boreholes), or may be related to structural features such as fractures, faults and collapse karst systems found in the Floridan aquifer (Cunningham and Walker, 2009; King et al., 2011), or some combination thereof. Prior geochemical, stable isotope and dissolved gas analyses and $\mathrm{H}^{3} /{ }^{4} \mathrm{He}$ relative age dating done for the SD and the ND provide evidence of confinement bypass pathways at the SD, specifically at well $6 \mathrm{U}, 14 \mathrm{U}$ and 12 -lower. Work done in this study further provides evidence of these pathways. Wells $6 \mathrm{U}, 14 \mathrm{U}$ and $12 \mathrm{~L}$ have $\mathrm{f}_{\text {inj }}$ between 0.5 and 0.9 , indicating groundwater samples contain a large fraction of injectate, with the remainder of wells less than 0.2 fraction of injectate. Large variations between the $\mathrm{Cl}^{-} / \mathrm{Br}^{-} \mathrm{BMMs}$ and the $\mathrm{NH}_{4}{ }^{+} \mathrm{BMM}$ would indicate that other sources of water may contribute to each sample water quality other than ambient hydrogeologic zone water and injectate endmembers. All BMMs show approximately 0.6 to $0.8 \mathrm{f}_{\text {inj }}$ for well $6 \mathrm{U}$ in the $\mathrm{MC1}$, and no large deviations are seen between the BMMs for most wells. 
Observed $\mathrm{Ca}^{2+}, \mathrm{Cl}^{-}$, and $\mathrm{Na}^{+}$concentrations were very similar to concentrations predicted by conservative mixing of the injectate with ambient water, according to the two endmember mixing model (Figure 4.12). The lower confining zones beneath the MC1 have $\mathrm{Cl}^{-}$concentrations close to seawater (Kohout, 1965; Reese, 1994; Walsh and Price, 2010), and if water were migrating up through the $\mathrm{MC} 2$ to the $\mathrm{MC} 1$, the increase in $\mathrm{Cl}^{-}$ would have a dampening effect on the $\mathrm{Cl}^{-} \mathrm{BMM}$, resulting in underestimating the $\mathrm{f}_{\text {inj }}$ compared to the $\mathrm{NH}_{4}{ }^{+} \mathrm{BMM}$ fraction of injectate. To illustrate this, a three member solution mixture for the MC1 was modeled in PHREEQC, using well 9U water as ambient, average injectate, and well $1 \mathrm{~L}$ in the MC2 as the three endmembers. An assumption was made that upward migrating fluids would migrate upward through the MC2 via buoyant flow, and by the time injecate water reached the MC1 it would contain $50 \%$ injectate and $50 \% \mathrm{MC} 2$ water. Water migrating upward from the Boulder Zone to the MC1 must migrate through almost 400 meters of aquifer matrix, and therefore an assumption of $50 \% / 50 \%$ mixture of injectate and $\mathrm{MC} 2$ water probably considerably overestimates the percentage of injectate. Comparison of observed $\mathrm{Cl}^{-}$and $\mathrm{Na}^{+}$ concentrations to those predicted by the three endmember model indicated all concentrations in the $\mathrm{MC} 1$ wells were lower when compared to the conservative mixing of the three solutions (Figure 4.12). The close match of the wells in the MC1 to the two member conservative mixing model, and the overestimation of ions compared in the three member mixing model to observed concentrations, suggests there is minimal mixture of $\mathrm{MC} 2$ water in any of the $\mathrm{MC} 1$ wells, and that injectate may bypass the underlying aquifers as it migrates upwards into the Middle Confining Unit One. 


\subsubsection{Porosity enhancement and confinement bypass pathways}

The undersaturated state for carbonate minerals in the injectate would suggest that there is porosity enhancement along the vertical flowpaths over time. If enhanced porosity was occurring along vertical flow paths, the $f_{\text {inj }}$ over time should increase in wells considered close to these vertical flowpaths, as increasing porosity would allow greater buoyant injectate migration. Chloride concentrations in injectate and concentrations in wells considered representative of ambient conditions do not change over time, as injectate has a freshwater source, and $\mathrm{Cl}^{-}$is in equilibrium with the aquifer (Walsh and Price, 2010). Therefore a $f_{\text {inj }}$ increasing over time would indicate increasing amounts of injectate reaching that particular well, which would be the case if there was porosity enhancement over time along the vertical flowpath. Chloride concentrations were analyzed over time for the SD injectate and well $6 \mathrm{U}$ in the $\mathrm{MC1}$, and the $\mathrm{f}_{\text {inj }}$ in well $6 \mathrm{U}$ and $14 \mathrm{U}$ was calculated for the period of record (1994 - 2008). Chloride concentrations in wells 6U and $14 \mathrm{U}$ decrease over time, and the calculated $\mathrm{f}_{\text {inj }}$ therefore increases with time (Figure 4.13), consistent with the interpretation of porosity enhancement along the vertical flowpaths in the vicinity of these wells. The $f_{\text {inj }}$ in wells hypothesized to be in the horizontal flow path and not near any vertical pathways (9U, 10U, 13U and 16U), no not show any significant change in $\mathrm{f}_{\text {inj }}$ over time (Figure 4.12 ), which would be expected based on the calcite oversaturated states in these samples.

The $\mathrm{f}_{\text {inj }}$ was much higher for the MC2 at the SD than the MC1 for wells thought to be near vertical bypass pathways, and the $\mathrm{SI}_{\text {calcite }}$ for the $\mathrm{MC} 2$ was more undersaturated than the $\mathrm{SI}_{\text {calcite }}$ for the Middle Confining Unit One. The MC2 lies approximately 125 meters 
above the Boulder Zone, whereas the MC1 lies almost 400 meters above the Boulder Zone, and injectate travel times along the vertical pathways to the $\mathrm{MC} 1$ are longer than the travel times to the Middle Confining Unit Two. The dissolved gas sample for well $12 \mathrm{~L}$ in the $\mathrm{MC} 2$ was lost, so comparison of the $\mathrm{CO}_{2}$ concentration to well $6 \mathrm{U}$ in the $\mathrm{MC} 1$ was not possible, but based on the $\mathrm{f}_{\text {inj }}$ of 0.9 for well $12 \mathrm{~L}$, the $\mathrm{CO}_{2}$ concentration in this well would be expected to be higher than in well 6-upper. The expected higher concentration of $\mathrm{CO}_{2}$ would allow for increased undersaturation with respect to calcite, which is reflected in the $\mathrm{SI}_{\text {calcite }}$ for well $12 \mathrm{~L}$ much lower than for well $6 \mathrm{U}$. The enhanced undersaturation would result in greater porosity enhancement in the vicinity of well 12L, and for the greater $f_{\text {inj }}$ in well $12 \mathrm{~L}$. As injectate travels upward in the vertical pathways to the $\mathrm{MC1}$, there is longer time for the methanogenetic uptake of $\mathrm{CO}_{2}$, resulting in decreasing excess $\mathrm{CO}_{2}$ concentrations in the vicinity of well $6 \mathrm{U}$, as is seen by water in $6 \mathrm{U}$ being near equilibrium, and a lower $\mathrm{f}_{\text {inj }}$ in this well than in well 12-lower.

The shorter travel time to the MC2 may also explain underprediction of the $\mathrm{NH}_{4}{ }^{+}$in the BMM for the MC2 wells, as $\mathrm{NH}_{4}{ }^{+}$may be lost through annamox (Van de Graaf et al., 1995; Thamdrup and Dalsgaard, 2002; Walsh and Price, in review) according to the equation:

$\mathrm{NH}_{4}^{+}+\mathrm{NO}_{2}^{-}=\mathrm{N}_{2}+2 \mathrm{H}_{2} \mathrm{O}$

Very little $\mathrm{NO}_{2}{ }^{-}$is available for this reaction, in either the injectate or the ambient groundwater, $(<0.2 \mathrm{mmols} / \mathrm{L}$ for both $)$, and once all available $\mathrm{NO}_{2}{ }^{-}$is consumed, $\mathrm{NH}_{4}{ }^{+}$ would become conservative. The $\mathrm{f}_{\mathrm{inj}}$ for the well $6 \mathrm{U}$ may represent the longer travel time 
to the $\mathrm{MC1}$, with $\mathrm{NH}_{4}{ }^{+}$nonreactive by the time it arrives in this zone, illustrated by the similarity of the $\mathrm{NH}_{4}{ }^{+}$BMM with the other conservative tracer binary mixing models.

\subsubsection{North District Results}

No major ion ambient groundwater concentrations were available for the ND APPZ wells, as all wells have elevated $\mathrm{NH}_{4}{ }^{+}$concentrations, so mixing curves could not be developed. However, the saturation states of wells in the APPZ at the ND are similar to the saturation states of wells in the $\mathrm{MC} 1$ at the SD that are hypothesized to be in horizontal flow paths in the MC1, and do not resemble wells hypothesized to be in the vicinity of vertical bypass pathways. This could be interpreted as upward migration through the lower confining units, however it could also be interpreted as injectate migrating upwards through an off-site confinement bypass pathway and once introduced into the APPZ, then migrates advectively with groundwater flow back to the site, similar to hypothesis suggested by King (2009).

\subsubsection{Suggested model for vertical migration of injectate}

This study suggests a possible geochemical scenario for upward fluid migration. Injectate migrates upwards as a result of buoyant density flow along fractures, either natural or anthropogenic, enhancing porosity along the vertical pathway, as suggested by the high $\mathrm{CO}_{2}$ concentrations and the saturation indices of the injectate (Figure 4.14). As water migrates, $\mathrm{CO}_{2}$ is consumed by methanogenesis, until all excess $\mathrm{CO}_{2}$ is consumed, and water equilibrates with native water, resulting in oversaturation of calcite. Reactive transport modeling done for coastal carbonate aquifers had large dissolution rates near the discharge area (similar in concept to this study's vertical confinement bypass pathways), 
which resulted in increasing permeability and enhancing further flow (Rezaei et al., 2005). Further studies for the study sites including reactive transport modeling may be able to quantify the dissolution rates and that may spatially and temporally affect upward fluid migration.

\subsubsection{Implications for Floridan aquifer storage and recovery}

Mixing of aquifer fluids is not confined in south Florida to the coastal seawaterfreshwater mixing zones, or to the wastewater injection sites, but can also affect any aquifer where fluids of different chemical composition mix. Aquifer storage and recovery sites (ASR) typically involve the recharge of a freshwater source, either freshwater aquifer or surface water into an aquifer of lesser water quality, and stored for some period of time before it is withdrawn. ASR sites have been increasingly studied as adverse chemical reactions, such as trace metal mobilization and precipitation of minerals can affect the quality and recovery efficiency of the recovered water (Stuyfzand, 1998; Brun et al., 1998; Mirecki, 2006; Arthur et al., 2009; Brown and Misut, 2010). Several counties in south Florida are considering storage of large volumes of treated domestic wastewater in the UFA. The results of this study suggest that the enhanced $\mathrm{CO}_{2}$ concentrations in the proposed stored treated wastewater will effect geochemical and biochemical reactions in the aquifer not previously predicted, and may affect future recovery rates and the geochemistry of the stored water. Inclusion of dissolved gases, especially $\mathrm{CO}_{2}$, in sampling regimes is recommended. 


\subsection{Conclusions}

Results of this study support the hypothesis of injectate migrating upward via confinement bypasses at the SD, with no evidence of mixing of deeper saline MC2 waters as it migrated upwards to the overlying Middle Confining Unit One. Observed conservative ion concentrations in wells with evidence of injectate migration were consistent with concentrations predicted by the conservative mixing of injectate and ambient MC1 Floridan aquifer endmembers.

Geochemical modeling of carbonate equilibrium described by conservative mixing of freshwater injectate into a deep saline aquifer overestimated the saturation states with respect to the carbonate minerals in groundwater with evidence of mixing with injectate. Injectate is enriched in $\mathrm{CO}_{2}$ as a result of the cryogenic treatment process at the two treatment plants in this study, and as a result injectate water is very undersaturated with respect to calcite. Once introduced into the aquifer, injectate excess $\mathrm{CO}_{2}$ becomes consumed by methanogenesis, with increasing saturation states as a result of decreasing $\mathrm{CO}_{2}$ concentrations along the injectate flowpaths. Porosity enhancement is predicted as injectate migrates through the vertical bypass pathways, allowing for greater upward buoyant flow over time, and may provide for dissolution of the aquifer matrix once introduced into overlaying aquifers in the vicinity of the bypass pathways.

Results for the ND could be interpreted as diffusive flow through the confining layers into the overlying aquifer. Alternatively, injectate may have moved vertically upward along a vertical pathways located off-site from the ND, and then migrated horizontally back to the site in the overlying aquifer with regional groundwater flow. 


\subsection{References}

Aris, A. Z., Praveena, S.M., and Abdullah, M.H, 2010. Saturation states of carbonate minerals in a fresh-water-seawater mixing zone of small tropical island's aquifer. Chinese Journal of Geochemistry, vol. 29, p. 278-286.

Arthur, J.D., Cowart, J.B., and Dabous, A.A., 2009. Mobilization of arsenic and other trace elements during aquifer storage and recovery, southwest Florida. U.S. Geological Survey Artificial Recharge Workshop Proceedings, G.R. Aiken and E.L. Kuniansky, ed., Sacramento, CA., April 2-4, 2202, U.S. Geological Survey Open File Report 02-89, p.47-50.

Back, W, and Hanshaw, B.B. 1970. Comparison of chemical hydrogeology of the carbonate peninsulas of Florida and Yucatan. Journal of hydrology, co. 10, p. 330 -368 .

Back, W., Hanshaw, B.B., Pyle, T.E., Plummer, N., and Weidie, A.E. 1979. Geochemical significance of groundwater discharge and carbonage solution to the formation of Caleta Xel Ha, Quintana Roo, Mexico. Water Resources Research, vol. 15, p. 1521-1535.

Back, W., Hanshaw, B.B., Herman, J.S., and Van Driel, J.N. 1986. Differential dissolution of a Pleistocene reef in the ground-water mixing zone of coastal Ucatan, Mexico. Geology, vol.4, p. 137-140.

Bates, L.B., McIntosh, J.C., Hohse, K.A., and Brooks, P.D. 2011. Influence of groundwater flowpaths, residence times and nutrients on the extent of microbial methanogenesis in coal beds: Powder River Basin, U.S.A. Chemical Geology, vol. 284 , p. $45-61$.

BC\&E/CH2MHill. 1977. Drilling and testing of the test-injection well for the MiamiDade Water and Sewer Authority. Contract S-153, BC\&E/CH2M Hill, Gainesville, Florida.

Brown, C.J., and Misut, P.E. 2010. Aquifer geochemistry at potential aquifer storage and recovery sites in coastal plain aquifers in the New York City area, USA. Applied Geochemistry, vol. 25, p. 1431-1452

Brun, A., Christensen, F.D., Christiansen, J.S., Stufyzand, P.J., and Timmer, H. 1998. Water quality modeling at the Langerak Deep-well recharge site: in Peters, J.H., et al., Artificial Recharge of Groundwater: Rotterdam, Netherlands. A.A. Balkema, $474 \mathrm{p}$.

Budd, D.A., Hammes, U., and Vacher, H.I., 1993. Calcite cementation in the upper Floridan aquifer: a modern example of for confined aquifer cementation models? Geology, vol. 21, p.33-36 
Cunningham, K.J., and Walker, C., 2009. Seismic-sag structures in Tertiary carbonate rocks beneath southeastern Florida, USA: evidence for hypogenic speleogenesis?: In Klimchouk, A.B., and Ford, D.C., eds., Hypogene Speleogenesis and Karst Hydrogeology of Artesian Basins. Ukrainian Institute of Speleology and Karstology, Special Paper No. 1, Simferopol, Ukraine, p. 151-158.

Dausman, A.M., Doherty, J., Langevin, C.D., and Dixon, J. 2010. Hypothesis testing of bouyant plume migration using a highly parameterized variable-density groundwater model at a site in Florida, USA. Hydrogeology Journal, vol. 18, pp. 147-160.

Davis, S. N., Whittemore, D.O., and Fabryka-Martin, J. 1998. Uses of Chloride/Bromide Ratios in Studies of Potable Water. Ground Water 36: 338 - 350.

Fish, J. E., and Stewart, M. 1991. Hydrogeology of the surficial aquifer system, Dade County, Florida. Water Resources Investigations Report Water Resources Investigations Report 90-4108, U.S. Geological Survey.

Haberfeld, J.L. 1991. Hydrogeology of effluent disposal zones, Floridan aquifer, South Florida. Ground Water 29:186-190.

Hanshaw, B.B., and Back, W. 1980. Cehmical mass-wasting of the northern Yucatan Peninsula by ground water dissolution. Geology, vol. 8, p. 710-724.

King, J.N., V. Walsh, K.J. Cunningham, F.S. Evans, C.D. Langevin, and Dausman A., 2009. Analytical models of the transport of deep-well injectate at the North District Wastewater Treatment Plant, Miami-Dade County, Florida, U.S.A.: Eos, Vol. 90, Number 52, 29 December 2009, Fall Meet. Supl., Abstract H21C-0869, 1 page.

King, J.N., K.J. Cunningham, and Foster A.L., 2011. Observation of a distinct transition in transport response to injection stress in the Floridan aquifer system, Southeastern Florida, USA: Abstract H13A-1174 presented at the 2011 Fall Meeting, AGU, San Francisco, Calif., 5-9 Dec. 1 page.

Kohout, F. A. 1965. A hypothesis concerning cyclic flow of salt water related to geothermal heating in the Floridan aquifer. Trans. N.Y. Acad. Sci., Ser. II vol. 28, p.249-271.

Langmuir, D., 1971. The geochemistry of carbonate ground waters in central Pennsylvania: Geochim. et Cosmochi. Acta, vol. 35, p.1023-1046.

Maliva, R.G., Guo, W., and T. Missimer. 2007. Vertical Migration of municipal wastewater in deep injection well systems, South Florida, USA. Hydrogeology Journal, vol.15, p. 1387-1396. 
McNeill, D.F. 2000. Final Report: A Review of Upward Migration of Effluent Related to Subsurface Injection at Miami-Dade Water and Sewer South District Plant: McNeill Geological Services Inc., Miami, FL.

Mirecki, J.E. 2006. Geochemical Models of Water-Quality Changes During Aquifer Storage recovery (ASR) Cycle tests, Phase 1: Geochemical Models Using Existing Data. US Army Corps of Engineers Report ERDC/EL TR-06-B, 66 pps.

Meyer, F. W. 1989a. Hydrogeology, Ground-Water Movement, and Subsurface Storage in the Floridan Aquifer System in Southern Florida. Professional Paper 1403-G, U.S. Geological Survey, Washington, D.C.

Meyer, F. W. 1989b. Subsurface storage of liquids in the Floridan Aquifer System in south Florida. Open-File Report 88-477 Open-File Report 88-477, U.S. Geological Survey, Tallahassee, Fl.

Miami-Dade Water and Sewer Department.1995. Plugging and Abandonment of BZ Well Cluster, South District Wastewater Treatment Plant, Miami-Dade Water and Sewer Department, Dade County, Florida.

Miami-Dade Water and Sewer Department. 2005. Monitoring well purging report for North District Wastewater Treatment Plant, Miami-Dade Water and Sewer Department, Dade County, Florida. Miami-Dade Water and Sewer Department, Miami, Florida.

Miller, J. A. 1986. Hydrogeologic Framework of the Floridan Aquifer System in Florida and in Parts of Georgia, Alabama, and South Carolina. Professional Paper 1403-B Professional Paper 1403-B, U.S. Geological Survey, Washington, D.C.

Parkhurst, D. L., and Appelo, C.A.J. 1999. User's guide to PHREEQC (version 2.18) - A computer program for speciation, batch-reaction, one-dimensional transport, and inverse geochemical calculations. Water-Resources Investigations Report 994259, U.S. Geological Survey.

Parkhurst, D.L., and Petkewich, M.D., 2002. Geochemical Modeling of an Aquifer Storage Recovery Experiment, Charleston, South Carolina, .S. Geological Survey Artificial Recharge Workshop Proceedings, G.R. Aiken and E.L. Kuniansky, ed., Sacramento, CA., April 2-4, 2202, U.S. Geological Survey Open File Report 0289, p.38-41.

Plummer, L.N., 1975. Mixing of seawater with calciunm carbonate groundwater, in Whitten, E.H.T., ed., Quantitaqtive Studeis in the Geological Sciences. Geological Society of America Memori, vol. 142, p. 219-236.

Plummer, L.N. 1977. Defining reactions and mass transfer in part of the Floridan aquifer, Water Resouces Research, vol.13, p. 801-812. 
Plummer, L.N., and Back, W. 1980. The mass balance approach: Application to interpreting the chemical evolution of hydrologic systems. American Journal of Sciences, vol. 280, p. $130-142$.

Price, R.M., and Herman, J.S. 1991. Geochemical investigation of saltwater-intrusion into a coastal carbonate aquifer: Mallorca, Spain. GSA Bulletin, vol. 103, p. 12701279 .

Reese, R. S. 1994. Hydrogeology and the Distribution and Origin of Salinity in the Floridan Aquifer System, Southeastern Florida. Water-Resources Investigations Report 94-4010, U.S. Geological Survey, Tallahassee, Florida.

Reese, R.S, and E. Richardson. 2008. Synthesis of the Hydrogeologic Framework of the Floridan Aquifer System and Delineation of a Major Avon Park Permeable Zone in Central and Southern Florida. Scientific Investigations Report 2007-5207. U.S. Geological Survey, Reston, VA.

Rezaei, M., Sanz, E., Raeisi, E., Ayora, C., Vázquez-Suñé, and Carrera, J. 2005. Reactive transport modeling of calcite dissolution in the fresh-salt water mixing zone. Journal of Hydrology, vol. 311, p. 282-298.

Rust Environmental and Infrastructure Inc. 1998. Report No. 1: Geochemical Study Report for South District Wastewater Treatment Plant, Dade County, Florida. 39523, Rust Environmental and Infrastructure Inc., Miami, Florida.

Saripalli, K.P., Sharma, M.M., and Bryant, S.L. 2000. Modeling injection well performance during deep-well injection of liquid wastes. Journal of Hydrology, vol. 227, p. 41-55.

Smart, P.L., Dawans, J.M., and Whitaker, F. 1988. Carbonate dissolution in a modern mixing zone. Nature, vol. 335, p. 811 - 813.

Sprinkle, C. L. 1989. Geochemistry of the Floridan Aquifer System in Florida and in Parts of Georgia, South Carolina, and Alabama. Professional Paper 1403-I, U.S.Geological Survey, Washington, D.C.

Starr, R. C., T. S. Green, and L. C. Hull. 2001. Evaluation of confining layer integrity beneath the South District Wastewater treatment Plant, Miami-Dade Water and Sewer Department, Dade County, Florida. INEEL/EXT-2001-00046, Geosciences Research Department, Idaho National Engineering and Environmental Laboratory, Idaho Falls, Idaho.

Stoessell, R.K., Ward., W.C., Ford, B.H., and Schuffer, J.D. 1989. Geological Society of American Bulletin, vol. 101, p. 159-169.

Stumm, W., and Morgan, J. J. 1996. Aquatic Chemistry. John Wiley \& Sons, Inc., New York. 
Stuyfzand, P.J. 1998. Quality changes upon injection into anoxic aquifers in the Netherlands: Evaluation of 11 experiments, in Peters, J.H., et al., Artificial Recharge of Groundwater: Rotterdam, Netherlands. A.A. Balkema, 474 p.

Thamdrup, B., and Dalsgaard, T. 2002. Production of $\mathrm{N}_{2}$ through anaerobic ammonium oxidation coupled to irtrate drduction in marine sediments. Applied Environmental Microbiology. vol. 68, p. 1312-1318.

Truesdell, A.H. and Jones, B.F., 1974. WATEQ, a computer program for calculating chemical equilibria in natural waters: Natl. Tech. Inf. Service, PB-220464 (1973), U.S.Geol. Survey Jour. Research, vol.2, p. 233-248.

Van de Graaf, A.A., Mulder, A.., De Bruijn, P., Jetten, M.S., Robertson, L.A.,and Kuene, J.G. 1995. Anaerobic oxidation of ammonium is a biologically mediated process. Applied Environmental Microbiology. vol. 61, p 1246-1251.

Walsh, V., and Price, R.M. 2010. Determination of vertical and horizontal pathways of injected fresh wastewater into a deep saline aquifer (Florida, USA) using natural chemical tracers. Hydrogeology Journal vol. 18, p 1027-1042.

Walsh, V., and Price, R.M. in review. The fate and transport of ammonium from fresh wastewater injected into a deep saline aquifer as determined from natural isotopes and dissolved gases.

Weiss, R.F. 1970. The solubility of nitrogen, oxygen and argon in water and seawater. Deep-Sea Research and Oceanographic Abstracts vol. 17, p 721-735.

Weiss, R.F. 1974. Carbon Dioxide in water and seawater; the solubility of a non-ideal gas. Marine Geochemistry. vol. 2, p 203-215.

Whitaker, F.F., and Smart, P.L. 1997. Groundwater circulation and geochemistry of a karstified bank-marginal fracture system, South Andros Island, Bahamas. Journal of Hydrology, vol. 197. p. 293-315.

Wicks, C.M., Herman, J.S., Randazzo, A.F., and Jee, J.L. 1995. Water-rock interactions in a modern coastal mixing zone. GSA Bulletin, September, 1995, vol. 107, p. 1023-1032.

Wiesenburg, D.A., and Guinasso, N.L. 1979. Journal of Chemical Engineering Data. vol. 24, p $356-360$.

Wigley, T.M.L., and Plummer, L.N. 1976. Mixing of carbonate waters. Geochimica et Cosmochimica Acta 40 (9), p. 989-995. 
Table 4.1 December 2007 water quality sampling results used in this study. * dissolved gas samples collected February 2008

\begin{tabular}{|c|c|c|c|c|c|c|c|c|c|c|c|c|c|c|c|c|c|}
\hline $\begin{array}{c}\text { Hydrogeologıc } \\
\text { unit }\end{array}$ & $\begin{array}{l}\text { open } \\
\text { interval } \\
\mathrm{m}\end{array}$ & $\begin{array}{l}\text { Well } \\
\text { ID }\end{array}$ & $\begin{array}{l}\text { Temp } \\
{ }^{\circ} \mathrm{C}\end{array}$ & $\mathrm{pH}$ & salinity & $\begin{array}{c}\mathrm{Cl}^{-} \\
\mathrm{mmol} / \mathrm{L}\end{array}$ & $\begin{array}{l}\mathrm{SO}_{4}{ }^{2-} \\
\mathrm{mmo} / \mathrm{L}\end{array}$ & $\begin{array}{c}\mathrm{Ca}^{2+} \\
\mathrm{mmol} / \mathrm{L}\end{array}$ & $\begin{array}{c}\mathrm{Mg}^{2+} \\
\mathrm{mmol} / \mathrm{L}\end{array}$ & $\begin{array}{c}\mathrm{Na}^{+} \\
\mathrm{mmol} / \mathrm{L}\end{array}$ & $\begin{array}{c}\mathrm{K}^{+} \\
\mathrm{mmol} / \mathrm{L}\end{array}$ & $\begin{array}{c}\mathrm{NH}_{4}^{+} \\
\mathrm{mmol} / \mathrm{L}\end{array}$ & $\begin{array}{l}\mathrm{HCO}_{3}^{-} \\
\mathrm{mmol} / \mathrm{L}\end{array}$ & $\begin{array}{c}\mathrm{Br} \\
\mathrm{mmol} / \mathrm{L}\end{array}$ & $\begin{array}{c}\mathrm{Si} \\
\mathrm{mmol} / \mathrm{L}\end{array}$ & $\begin{array}{c}{ }^{*} \mathrm{CO}_{2} \\
\mathrm{mmol} / \mathrm{L}\end{array}$ & $\begin{array}{c}{ }^{*} \mathrm{CH}_{4} \\
\mathrm{mmol} / \mathrm{L}\end{array}$ \\
\hline $\begin{array}{c}\text { Biscayne } \\
\text { Aquifer }\end{array}$ & surface & S-EFF & 28.22 & 6.69 & $<2$ & 8.45 & 1.34 & 1.48 & 0.31 & 3.15 & 0.39 & 1.29 & 3.28 & 0.21 & 0.25 & 3.010 & 0.000 \\
\hline \multirow{4}{*}{$\begin{array}{l}\text { Upper } \\
\text { Floridan } \\
\text { aquifer }\end{array}$} & $306-316$ & BZ1 & 24.13 & 7.58 & $<2$ & 24.85 & 3.74 & 1.38 & 3.03 & 22.88 & 1.04 & 0.00 & 3.23 & 0.03 & 0.39 & 0.116 & 0.001 \\
\hline & $299-332$ & $1 \mathrm{U}$ & 23.82 & 8.13 & $<2$ & 20.76 & 3.79 & 1.37 & 2.95 & 23.18 & 1.09 & 0.01 & 3.33 & 0.03 & 0.43 & 0.015 & 0.002 \\
\hline & $299-320$ & $3 U$ & 23.96 & 8.07 & $<2$ & 31.34 & 4.56 & 1.50 & 3.04 & 25.40 & 1.17 & 0.01 & 3.34 & 0.03 & 0.43 & 0.024 & 0.002 \\
\hline & $299-311$ & $2 U$ & 27.66 & 8.06 & $<2$ & 18.62 & 3.57 & 1.35 & 3.02 & 23.40 & 1.21 & 0.01 & 3.31 & 0.03 & 0.45 & 0.102 & 0.001 \\
\hline \multirow{6}{*}{ MC1 } & $454-484$ & $9 U$ & 25.19 & 7.66 & 6.79 & 126.93 & 5.12 & 4.54 & 12.80 & 103.52 & 3.35 & 0.09 & 2.10 & 0.18 & 0.18 & 0.045 & 0.028 \\
\hline & $454-485$ & $10 U$ & 23.37 & 7.61 & 7.20 & 123.80 & 5.38 & 5.21 & 12.30 & 98.74 & 3.17 & 0.08 & 2.74 & 0.18 & 0.27 & 0.049 & 0.024 \\
\hline & $451-475$ & $13 U$ & 23.80 & 7.86 & 7.19 & 123.29 & 6.37 & 4.97 & 10.90 & 88.26 & 3.53 & 0.18 & 3.59 & 0.16 & 0.33 & 0.076 & 0.063 \\
\hline & $454-485$ & $16 U$ & 23.03 & 7.65 & 6.78 & 112.52 & 5.83 & 4.42 & 10.82 & 91.26 & 3.48 & 0.55 & 4.49 & 0.24 & 0.26 & 0.211 & 0.081 \\
\hline & $454-480$ & $14 U$ & 23.50 & 7.63 & 4.54 & 68.29 & 4.03 & 3.42 & 6.87 & 54.55 & 2.58 & 0.60 & 4.83 & 0.10 & 0.33 & 0.555 & 0.065 \\
\hline & $454-483$ & $6 \mathrm{U}$ & 24.96 & 7.48 & 2.91 & 38.61 & 2.85 & 2.87 & 4.65 & 32.84 & 1.91 & 1.02 & 5.61 & 0.06 & 0.30 & 0.703 & 0.073 \\
\hline \multirow{2}{*}{ MC1/APPZ } & $501-510$ & $2 \mathrm{~L}$ & 25.21 & 7.45 & 12.05 & 229.97 & 6.54 & 9.38 & 19.38 & 162.59 & 4.76 & 0.01 & 1.67 & 0.33 & 0.23 & 0.087 & 0.001 \\
\hline & $481-507$ & BZ2 & 24.44 & 7.80 & 8.11 & 132.03 & 5.73 & 5.24 & 13.95 & 120.71 & 4.02 & 0.30 & 3.43 & 0.34 & 0.25 & 0.119 & 0.063 \\
\hline \multirow{8}{*}{ MC2 } & $546-573$ & $9 \mathrm{~L}$ & 23.31 & 7.70 & 33.80 & 571.97 & 26.80 & 14.10 & 50.94 & 661.00 & 16.80 & 0.00 & 2.77 & 0.88 & 0.26 & 0.064 & 0.001 \\
\hline & $546-576$ & $16 \mathrm{~L}$ & 23.00 & 7.58 & 33.61 & 607.20 & 24.49 & 14.40 & 49.87 & 482.52 & 16.68 & 0.00 & 2.93 & 0.79 & 0.18 & 0.076 & 0.001 \\
\hline & $540-577$ & $3 \mathrm{~L}$ & 23.10 & 7.50 & 32.23 & 562.07 & 24.59 & $14.65^{\circ}$ & 49.78 & 480.13 & 17.52 & 0.00 & $2.77^{\top}$ & $0.81^{\prime \prime}$ & 0.20 & 0.043 & 0.000 \\
\hline & $519-561$ & $4 \mathrm{~L}$ & 23.42 & 7.47 & 31.18 & 557.19 & 21.68 & 14.75 & 46.66 & 458.07 & 16.24 & 0.00 & 2.77 & 0.79 & 0.01 & 0.156 & 0.001 \\
\hline & $561-587$ & $1 \mathrm{~L}$ & 23.45 & 7.44 & 33.30 & 591.68 & 27.29 & 14.35 & 55.21 & 535.89 & 17.70 & 0.00 & 2.64 & 0.84 & 0.19 & 0.039 & 0.000 \\
\hline & $530-562$ & $13 \mathrm{~L}$ & 23.70 & 7.47 & 30.43 & 508.19 & 22.82 & 9.53 & 35.51 & 349.98 & 11.61 & 0.11 & 3.15 & 0.77 & 0.30 & 0.057 & 0.016 \\
\hline & $546-576$ & $10 \mathrm{~L}$ & 23.80 & 7.55 & 24.24 & 429.44 & 20.36 & 7.54 & 29.79 & 98.74 & 9.54 & 0.20 & 3.23 & 0.59 & 0.26 & 0.064 & 0.053 \\
\hline & $546-576$ & $12 \mathrm{~L}$ & 25.40 & 7.35 & 3.78 & 57.40 & 2.98 & 2.82 & 5.76 & 48.80 & 1.59 & 0.77 & 5.41 & 0.09 & 0.39 & & \\
\hline \multirow{2}{*}{$\begin{array}{c}\text { Biscayne } \\
\text { Aquifer }\end{array}$} & & & & & & & & & & & & & & & & & \\
\hline & surface & N-EFF & 26.60 & 7.04 & $<2$ & 16.92 & 1.00 & 1.47 & 1.93 & 23.49 & 0.90 & 0.83 & 1.80 & 0.04 & 0.31 & 2.473 & 0.005 \\
\hline \multirow{4}{*}{$\begin{array}{c}\text { UFA/Upper } \\
\text { MC1 }\end{array}$} & $354-385$ & N-FA-1U & 22.10 & 8.00 & 4.08 & 81.77 & 2.68 & 3.24 & 7.41 & 65.25 & 1.56 & 0.02 & 1.05 & 0.12 & 0.10 & 0.016 & 0.003 \\
\hline & $351-384$ & N-FA-2U & 21.97 & 8.20 & 3.94 & 76.86 & 2.76 & 2.99 & 6.99 & 65.25 & 1.61 & 0.01 & 1.41 & 0.11 & 0.10 & 0.015 & 0.009 \\
\hline & $354-379$ & N-FA-3U & 21.70 & 8.30 & 3.72 & 74.32 & 2.27 & 2.74 & 6.99 & 65.25 & 1.64 & 0.01 & 1.15 & 0.11 & 0.11 & 0.003 & 0.003 \\
\hline & 354 - 379 & N-FA-4U & 19.60 & 8.00 & 4.02 & 76.95 & 2.63 & 2.74 & 6.99 & 65.25 & 1.66 & 0.01 & 1.08 & 0.13 & 0.31 & 0.019 & 0.002 \\
\hline \multirow{4}{*}{$\begin{array}{c}\text { Lower } \\
\text { MC1/APPZ }\end{array}$} & $430-460$ & N-FA-3L & 18.60 & 7.70 & 26.48 & 391.08 & 14.22 & 8.23 & 35.38 & 330.58 & 9.72 & 0.21 & 3.28 & 0.65 & 0.03 & 0.095 & 0.016 \\
\hline & $430-461$ & N-FA-1L & 19.50 & 7.40 & 27.04 & 399.63 & 18.53 & 7.49 & 38.68 & 347.98 & 10.74 & 0.24 & 3.44 & 0.65 & 0.00 & 0.124 & 0.017 \\
\hline & $430-460$ & N-FA-4L & 18.50 & 7.40 & 22.52 & 401.46 & 13.68 & 8.23 & 34.56 & 321.88 & 9.46 & 0.23 & 3.28 & 0.65 & 0.11 & 0.163 & 0.015 \\
\hline & $431-459$ & $\mathrm{~N}-\mathrm{FA}-2 \mathrm{~L}$ & 20.12 & 7.50 & 25.61 & 407.02 & 18.04 & 7.24 & 36.62 & 334.93 & 10.23 & 0.27 & 3.61 & 0.78 & 0.24 & 0.114 & 0.019 \\
\hline
\end{tabular}


Table 4.2 Log $\mathrm{P}_{\mathrm{CO} 2}$ and Saturation indices of calcite, dolomite, aragonite and gypsum. Well with elevated $\mathrm{NH} 4+$ concentrations are italicized. $\mathrm{P}_{\mathrm{CO} 2}$ are calculated from observed $\mathrm{CO}_{2}$ concentrations.

\begin{tabular}{|c|c|c|c|c|c|}
\hline Sample ID & $\log \mathrm{P}_{\mathrm{CO} 2}$ & $\mathrm{SI}_{\mathrm{C}}$ & $\mathrm{Sl}_{\mathrm{a}}$ & $\mathrm{SI}_{\mathrm{d}}$ & $\mathrm{SI}_{\text {gyp }}$ \\
\hline $\mathrm{EFF}_{12-07}$ & -0.98 & -1.13 & -1.28 & -2.79 & -1.62 \\
\hline $\mathrm{EFF}_{\text {avg }}$ & -0.98 & -1.13 & -1.28 & -2.79 & -1.62 \\
\hline 10 & -3.37 & 0.85 & 0.7 & 2.14 & -1.48 \\
\hline $2 U$ & -2.503 & 0.1 & -0.04 & 0.69 & -1.5 \\
\hline $3 U$ & -3.151 & 0.68 & 0.53 & 1.78 & -1.4 \\
\hline BZU & -2.466 & 0.02 & -0.12 & 0.5 & -1.48 \\
\hline $9 U$ & -2.884 & 0.3 & 0.15 & 1.2 & -1.24 \\
\hline $10 U$ & -2.836 & 0.5 & 0.36 & 1.51 & -1.15 \\
\hline $13 U$ & -2.648 & 0.55 & 0.41 & 1.58 & -1.08 \\
\hline $16 U$ & -2.222 & 0.29 & 0.14 & 1.08 & -1.16 \\
\hline $14 U$ & -1.775 & -0.08 & -0.23 & 0.26 & -1.29 \\
\hline $6 U$ & -1.67 & -0.01 & -0.16 & 0.32 & -1.39 \\
\hline $6 U$ w/eff PCO2 & & -0.72 & -0.87 & -1.06 & -1.57 \\
\hline $2 \mathrm{~L}$ & -2.582 & 0.01 & -0.13 & 0.5 & -0.99 \\
\hline$B Z L$ & -2.457 & 0.33 & 0.19 & 1.24 & -1.17 \\
\hline $1 \mathrm{~L}$ & -2.957 & 0.6 & 0.46 & 1.96 & -0.54 \\
\hline $9 \mathrm{~L}$ & -2.748 & 0.44 & 0.3 & 1.61 & -0.58 \\
\hline $16 \mathrm{~L}$ & -2.681 & 0.47 & 0.32 & 1.63 & -0.56 \\
\hline $3 L$ & -2.904 & 0.62 & 0.48 & 1.94 & -0.55 \\
\hline $4 \mathrm{~L}$ & -2.34 & 0.14 & -0.01 & -0.94 & -0.59 \\
\hline $10 L$ & -2.723 & 0.49 & 0.35 & 1.72 & -0.69 \\
\hline $12 L w / e f f P_{\mathrm{CO} 2}$ & & -0.78 & -0.93 & -1.11 & -1.45 \\
\hline $13 L$ & -2.779 & 0.52 & 0.37 & 1.76 & -0.68 \\
\hline N-EFF & -1.067 & -1.67 & -1.81 & -3.07 & -1.92 \\
\hline $\mathrm{N}-1 \mathrm{U}$ & -3.379 & 0.09 & -0.06 & 0.64 & -1.49 \\
\hline$N-2 U$ & -3.418 & 0.34 & 0.19 & 1.15 & -1.5 \\
\hline $\mathrm{N}-3 \mathrm{U}$ & -4.072 & 0.61 & 0.46 & 1.72 & -1.61 \\
\hline $\mathrm{N}-4 \mathrm{U}$ & -3.283 & -0.07 & -0.22 & 0.35 & -1.55 \\
\hline$N-1 L$ & -2.516 & 0.2 & 0.05 & 1.21 & -0.84 \\
\hline
\end{tabular}




\subsection{Figures}

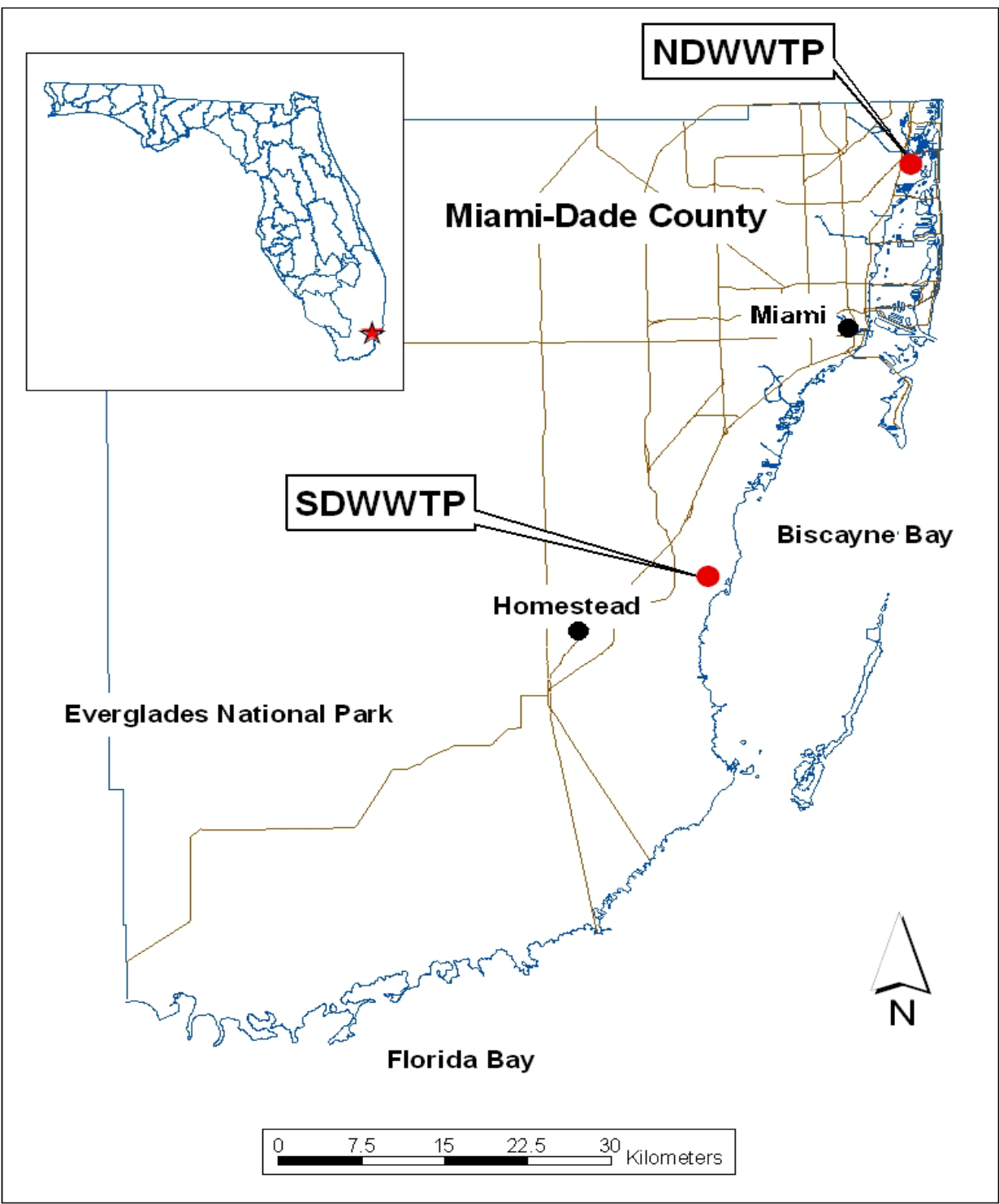

Figure 4.1 Location of the South District Wastewater Treatment Plant and North District Wastewater Treatment plant in Miami-Dade County Florida, USA. Inset locates the two sites in the state of Florida. 


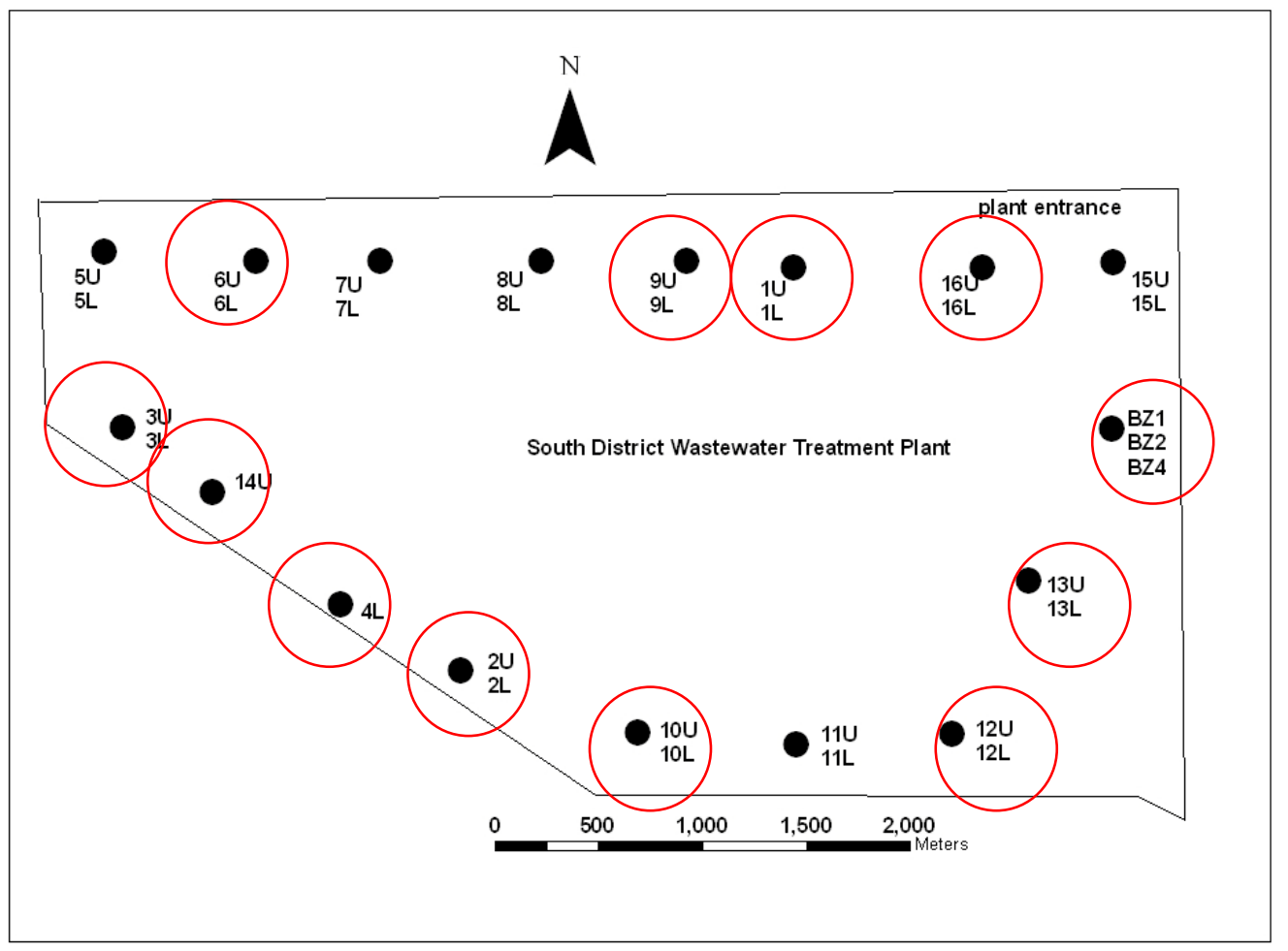

Figure 4.2 Well locations at the SDWWTP. Wells 1U, 2U, 3U and BZU monitor the UFA. Wells 5U, 6U, 7U, 8U, 9U, 10U, 11U, 12U, 13U,14U, 15U and 16U monitor the MCA; wells 2L and BZ2 monitor the APPZ; wells labeled 1L, 31, 4L, 5L, 6L, 7L, 8L, 8L, 9L, 10L, 11L, 12L, 13L, 15L and 16L monitor the saline MC2 zone. Wells circled in red were used in this study. 


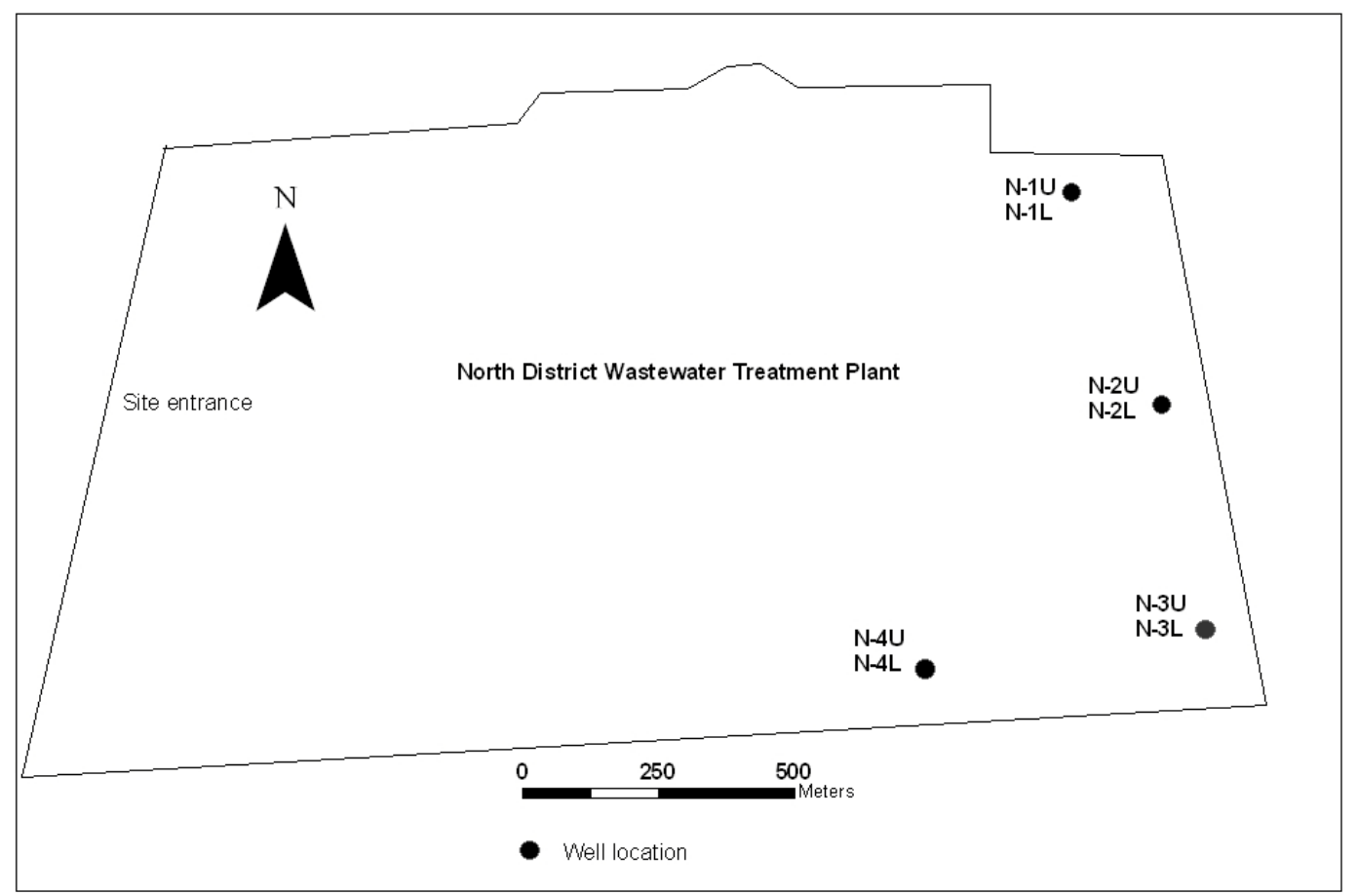

Figure 4.3 Well Well locations at the NDWWTP. Wells labeled with a "U" monitor the lower UFA and Upper MC1 zones in the Floridan aquifer system. The wells labeled with a "L" monitor the lower MC1 and APPZ. 


\begin{tabular}{|c|c|c|c|c|c|}
\hline Series & Geologic unit & \multicolumn{2}{|c|}{ Hydrogeologic unit (HU) } & $\begin{array}{l}\text { Approximate } \\
\text { Thickness } \\
\text { (meters) }\end{array}$ & $\begin{array}{c}\text { Base of } \\
\mathrm{HU} \\
(\mathrm{m} \text { bls })^{* *}\end{array}$ \\
\hline Holocene and Pleistocene & Various ${ }^{*}$ & \multirow{2}{*}{ 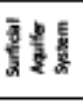 } & Biscayne Aquifer & \multirow{2}{*}{60} & \multirow[b]{2}{*}{60} \\
\hline Pliocene & Tamiami Formation & & Lower Tamiami Aquifer & & \\
\hline \multirow[t]{2}{*}{ Miocene and late Oligocene } & \multirow[t]{2}{*}{ Hawthorn Group } & $\frac{y}{8} \frac{5}{2}$ & Confining Unit & 245 & 305 \\
\hline & & \multirow{7}{*}{ 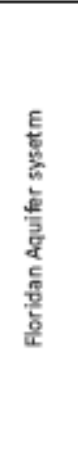 } & Upper Floridan Aquifer (UF) & 30 & 335 \\
\hline Early Oligocene & Suwanee Limestone & & \multirow[b]{2}{*}{ Middle Confining Unit (M1) } & \multirow[b]{2}{*}{125} & \multirow[b]{2}{*}{450} \\
\hline \multirow{5}{*}{ Eocene } & \multirow[b]{3}{*}{ Avon Park Formation } & & & & \\
\hline & & & Avon Park Permeable Zone & 30 & 490 \\
\hline & & & MC2 & 240 & 730 \\
\hline & Oldsmar Formation & & LFA & 125 & 255 \\
\hline & & & $B Z$ & $90 ?$ & $?$ \\
\hline
\end{tabular}

* includes Miami Limestone, Fort Thompson Formation, Anastatia Formation, Key Largo Limestone

** meters below land surface

Figure 4.4 Geologic and hydrogeologic framework of the north and south sites, modified from Reese and Richardson, 2008. 

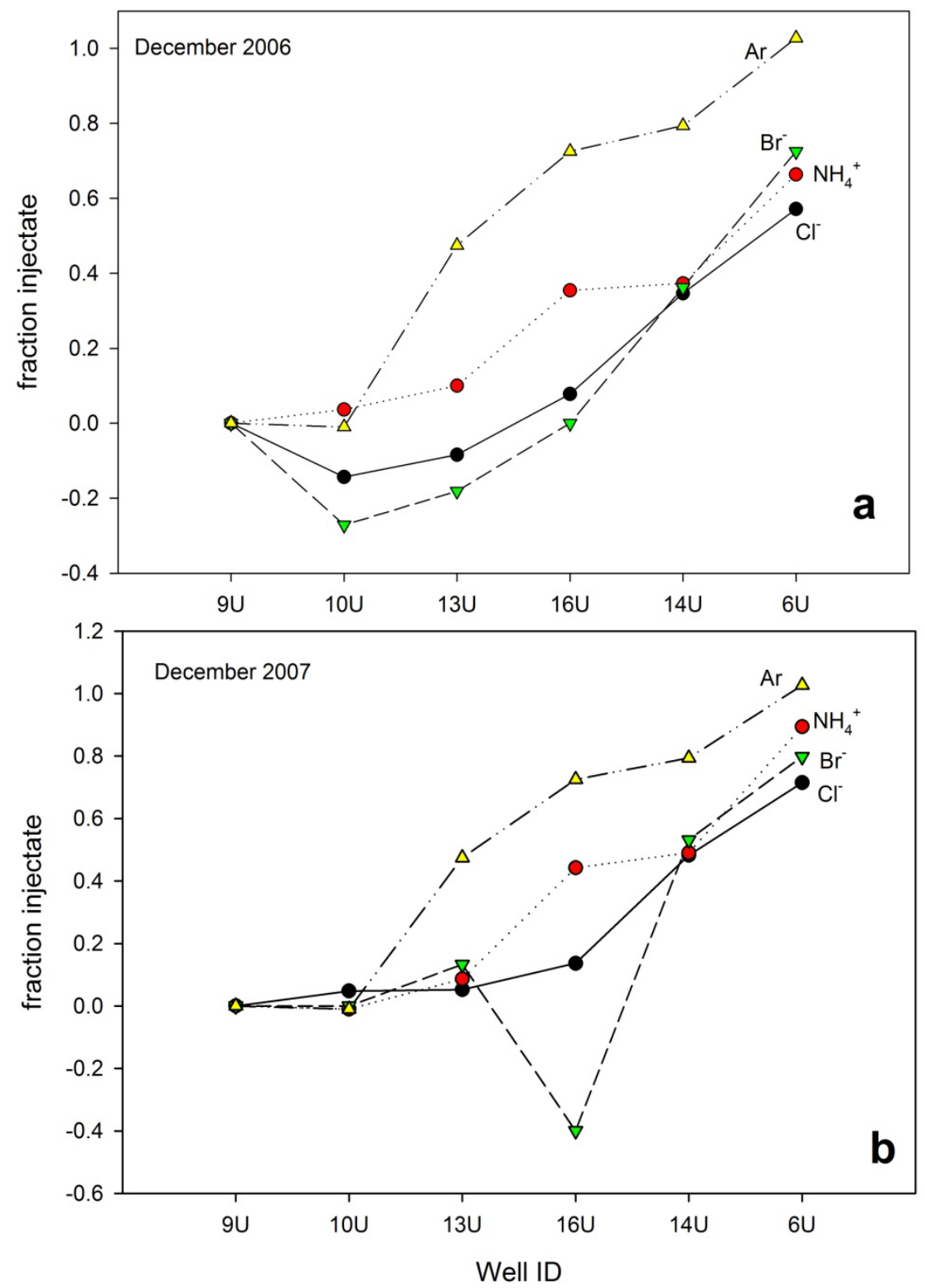

Figure 4.5 Binary mixing model results for the MC1 at the SD for the December 2006 (graph a) and December 2007 (graph b) sampling events. Black circles are the $\mathrm{Cl}^{-} \mathrm{BMM}$, green triangles are the $\mathrm{Br}^{-} \mathrm{BMM}$, red circles are the $\mathrm{NH}_{4}{ }^{+} \mathrm{BMM}$, and the yellow triangles are the Argon BMM. Wells have similar $\mathrm{Cl}^{-}, \mathrm{Br}^{-}$and $\mathrm{NH}_{4}^{+} \mathrm{BMM}^{-}$ results, with the exception of well $16 \mathrm{U}$. Argon appears to overpredict the $\mathrm{f}_{\text {inj. }}$. 

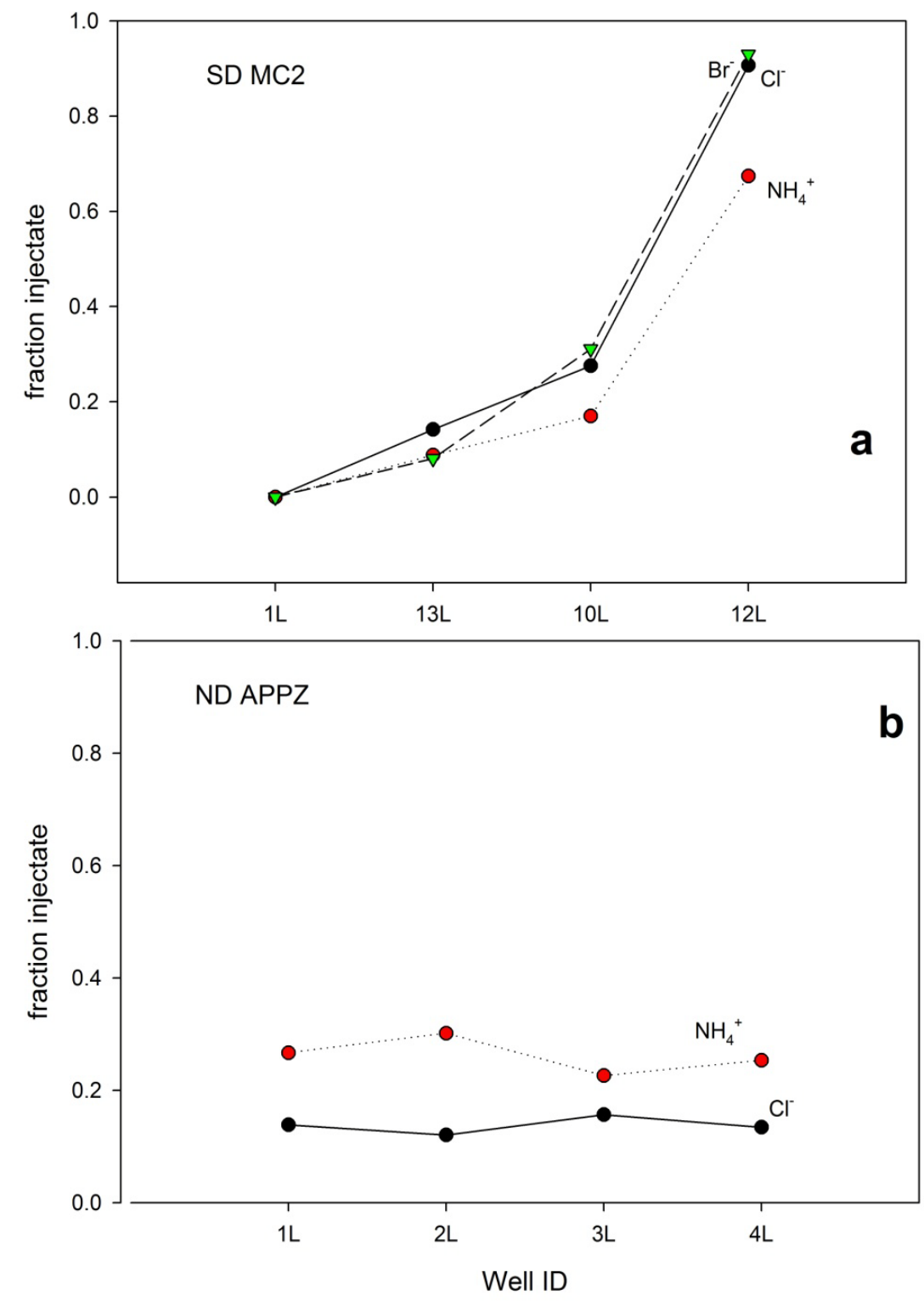

Figure 4.6 BMM results for the SD MC2 (graph a) and the ND APPZ zones (graph b). Argon sample for the endmember of the MC2 zone was lost, and therefore a Argon BMM could not be completed. Wells at the SD MC2 have similar $\mathrm{Cl}^{-}$and $\mathrm{Br}^{-}$ BMM results, while $\mathrm{NH}_{4}{ }^{+}$BMM may slightly underpredict $\mathrm{f}_{\text {inj. }}$. The $\mathrm{NH}_{4}{ }^{+} \mathrm{BMM}$ appears to overpredict the $f_{\text {inj }}$ for the ND wells. 


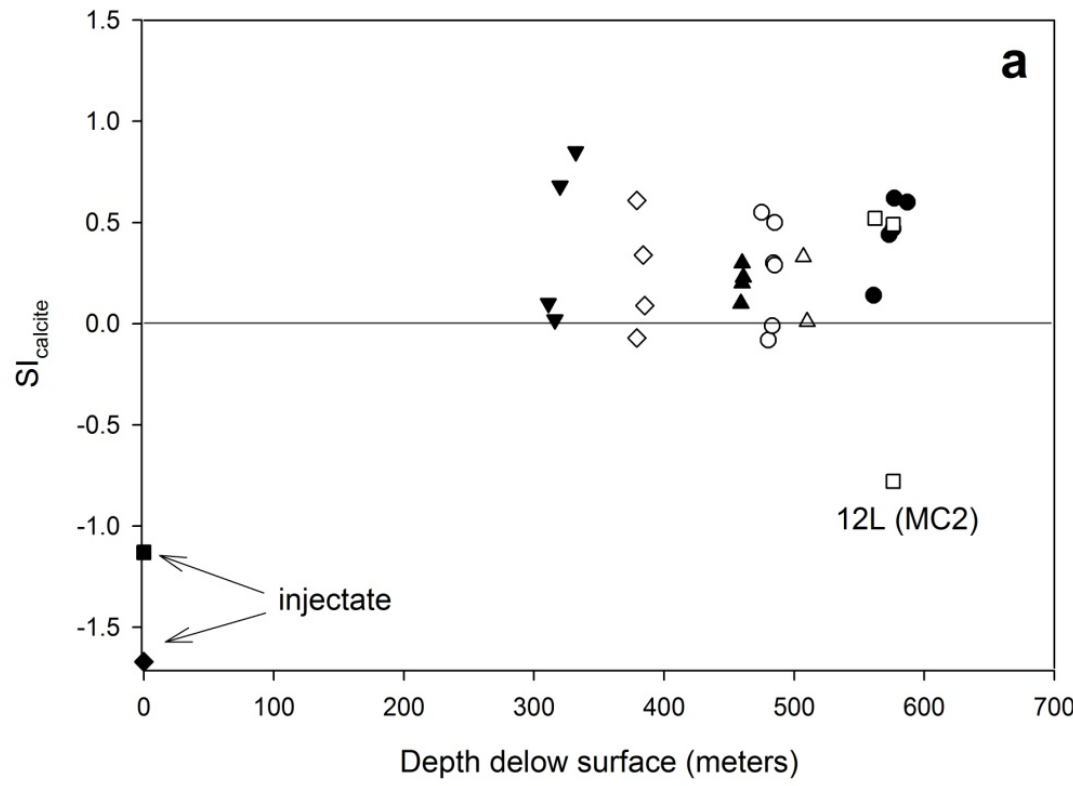

\begin{tabular}{|ll|}
\hline$\bullet$ & $M C 2$ \\
0 & $M C 1$ \\
$\boldsymbol{\nabla}$ & UFA \\
$\triangle$ & APPZ \\
$\square$ & $M C 2$ \\
$\diamond$ & ND UFA \\
$\Delta$ & ND APPZ \\
\hline
\end{tabular}

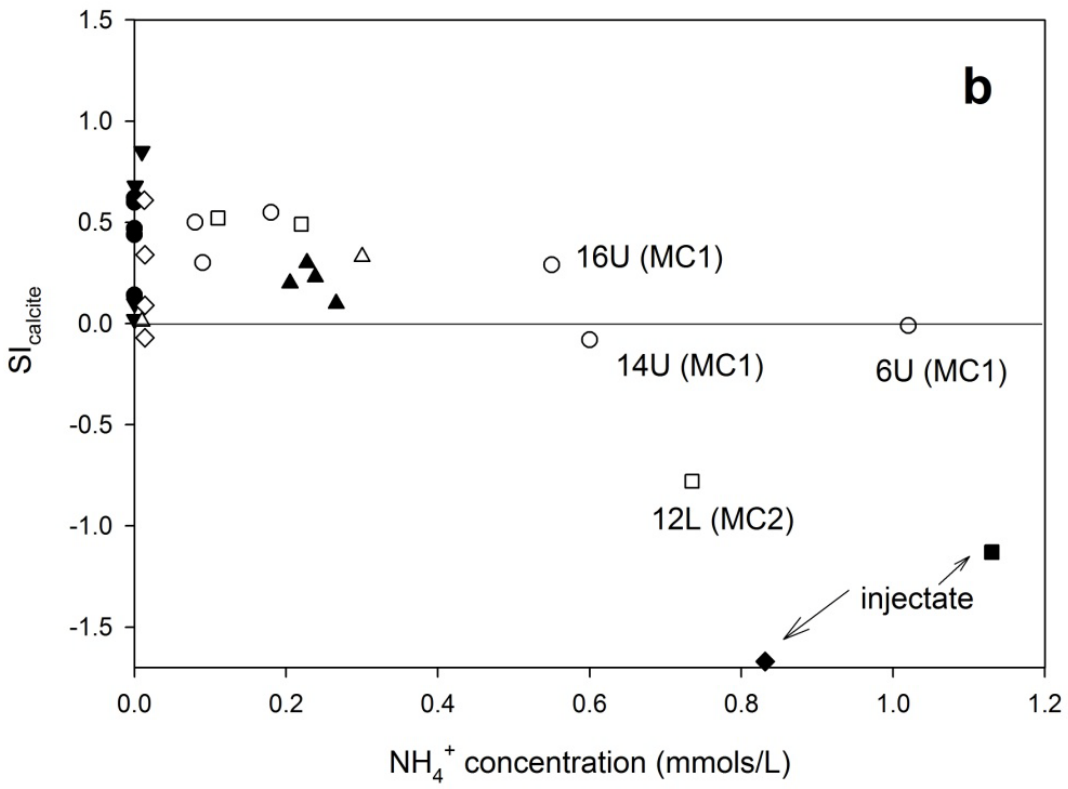

Figure 4.7 Saturation indices (SI) versus sample depth in aquifer (graph a), and versus sample $\mathrm{NH}_{4}{ }^{+}$concentrations (graph b). Saturation state points are from the SD, except those noted for the ND in the legend. Saturation states did not appear to be related to depth in the aquifer, but rather appear to be related to the $\mathrm{NH}_{4}{ }^{+}$ concentration for the $\mathrm{MC} 1$ and $\mathrm{MC} 2$ at the $\mathrm{SD}$. 

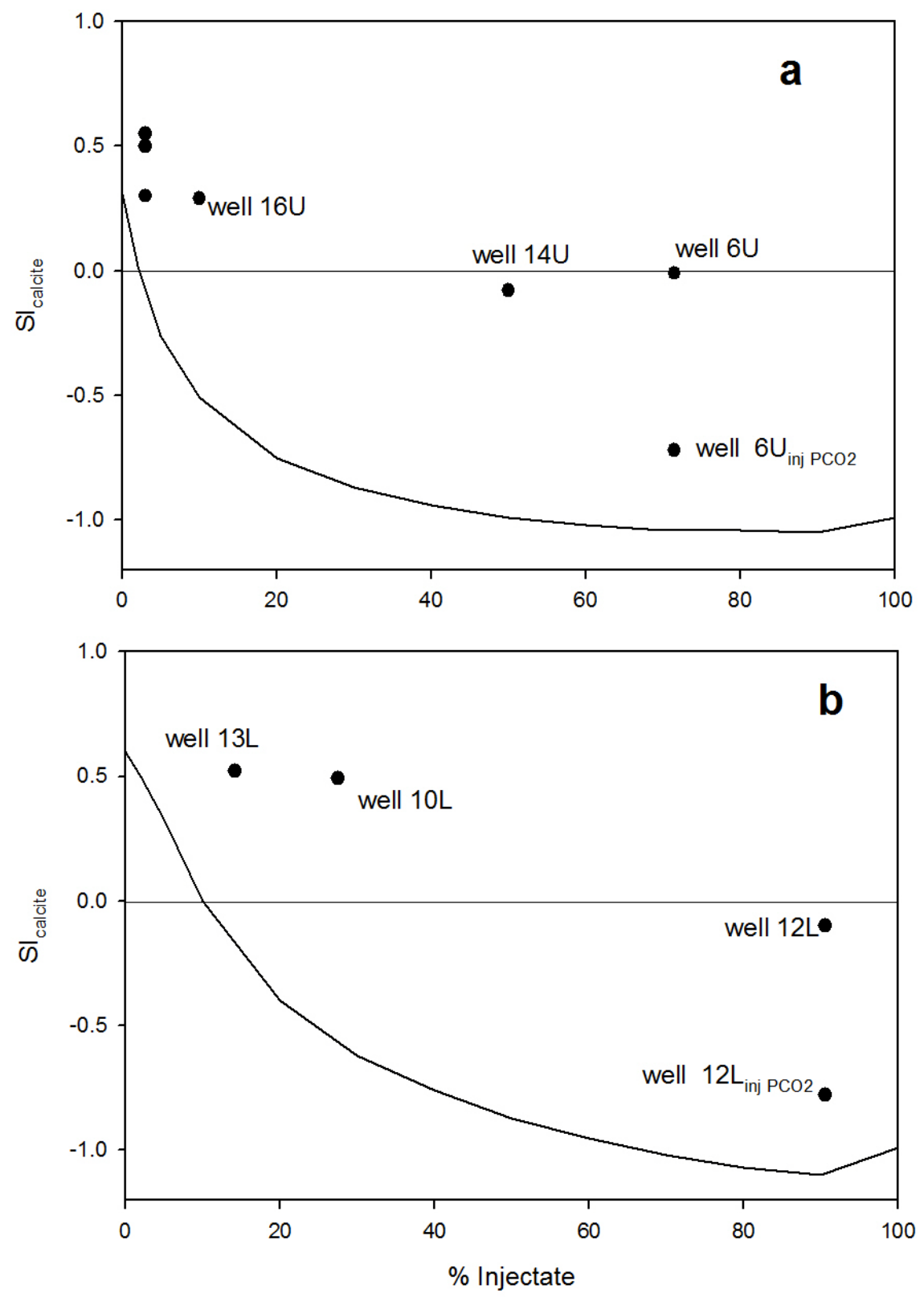

Figure 4.8 PHREEQC calculated SI for calcite as percentage of injectate (curve), and calculated SI from wells in the MC1 (graph a) and the MC2 (graph b) at the SD. The data points indicated as well $6 \mathrm{U}_{\text {inj PCO2 }}$ and well $12 \mathrm{~L}_{\text {inj } P C O 2}$ is the saturation index calculated for those wells using the $\mathrm{P}_{\mathrm{CO} 2}$ for injectate. 

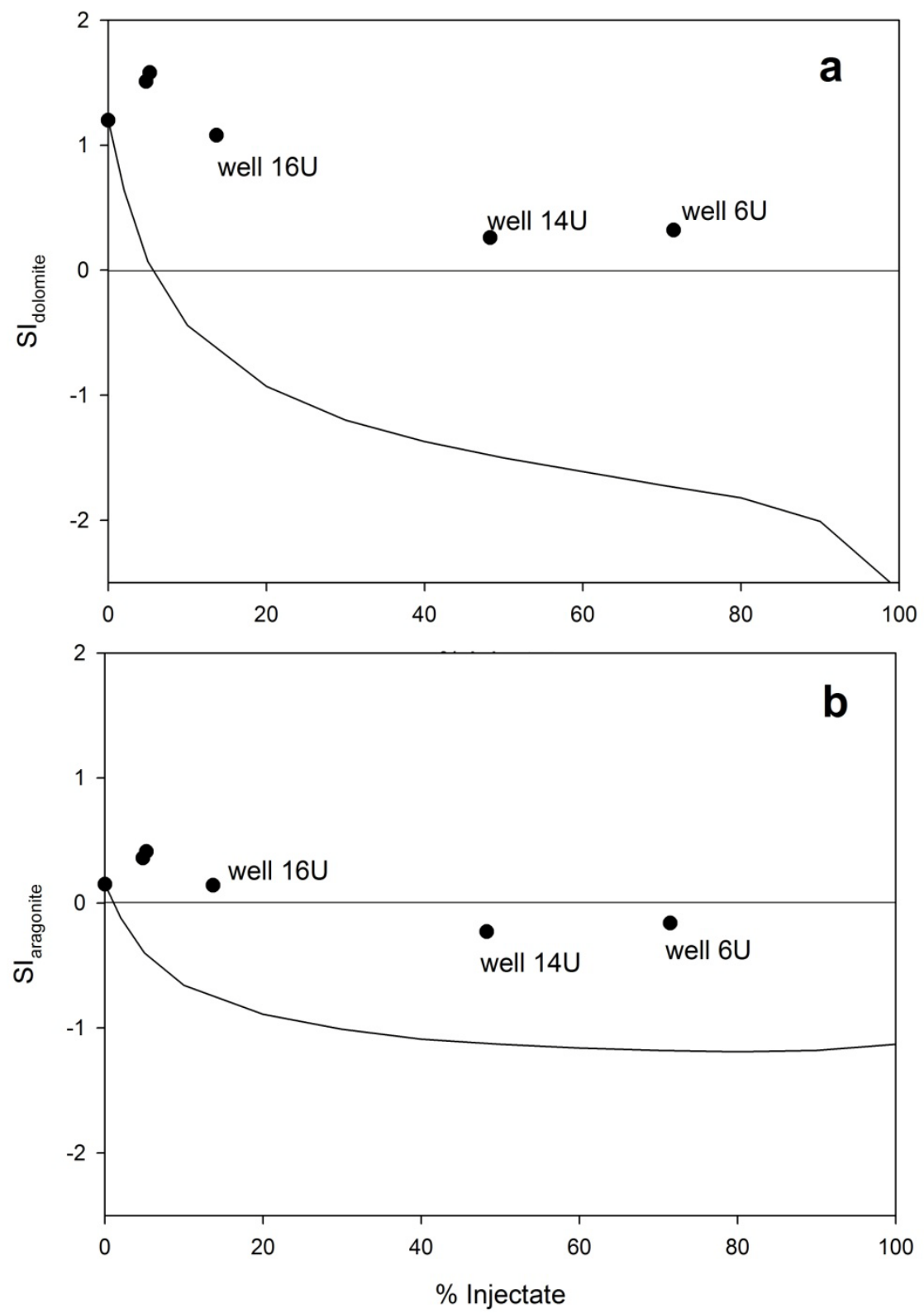

Figure 4.9 PHREEQC calculated SI for dolomite (graph a) and aragonite (graph b) as percentage of injectate (curve), and calculated SI from wells in the MC1 at the SD. 


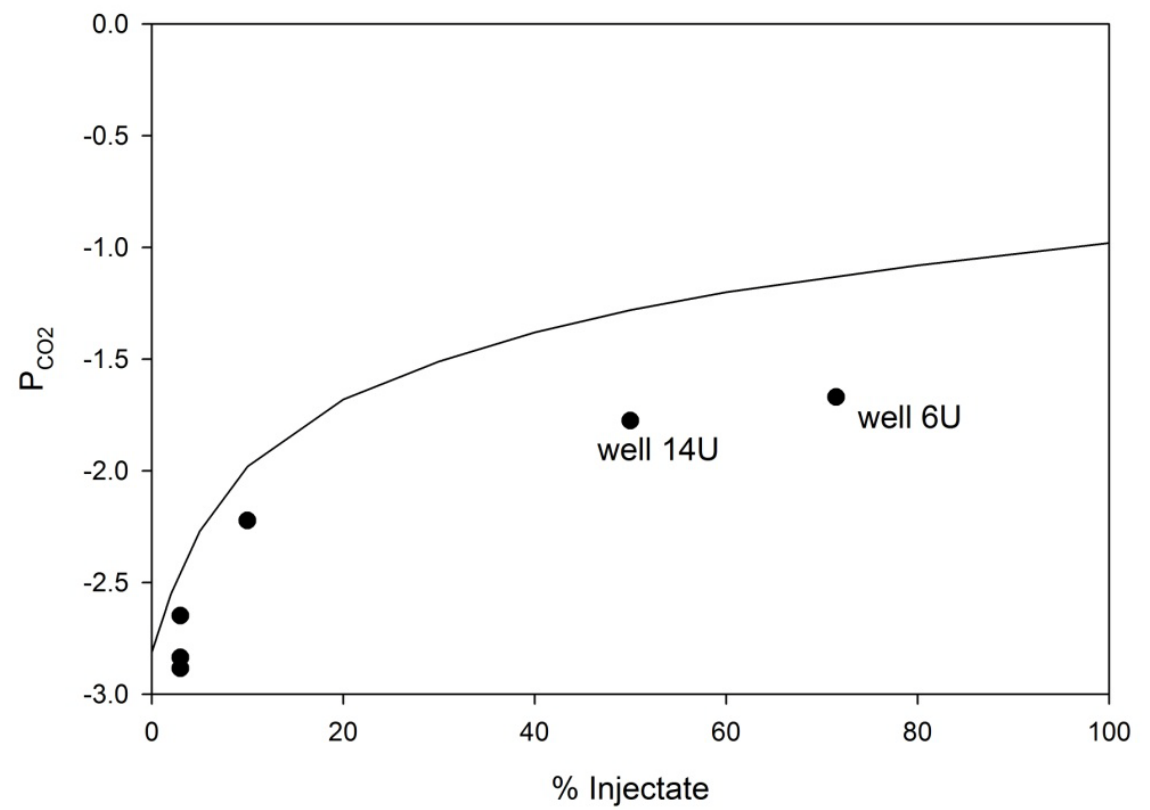

Figure 4.10 PHREEQC calculated $\mathrm{P}_{\mathrm{CO} 2}$ as percentage of injectate curve, with observed $\mathrm{P}_{\mathrm{CO} 2}$ plotted for wells in the $\mathrm{MC} 1$ at the SD. 


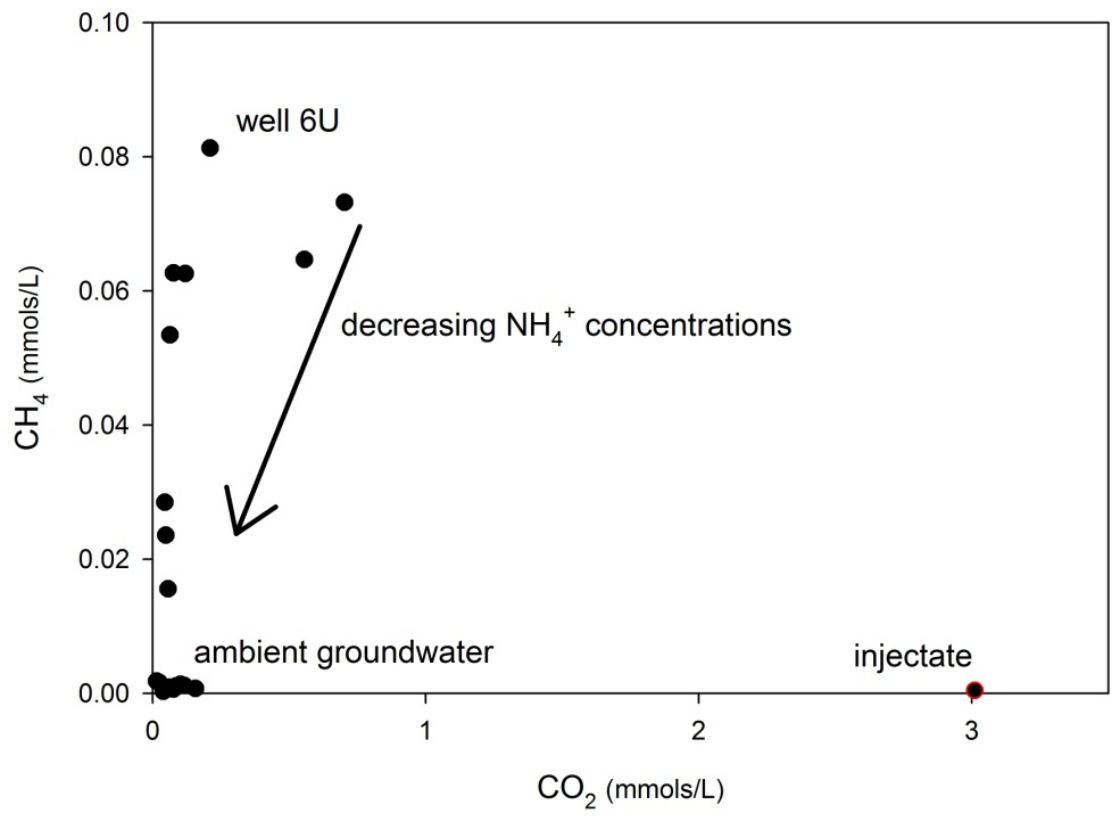

Figure 4.11 $\mathrm{CO}_{2}$ versus methane concentrations at the SD. Injectate is highly enriched in $\mathrm{CO}_{2}$ and depleted in $\mathrm{CH}_{4}$ as a result of the cryogenic treatment and methane co-generation processes at the SD. Wells with elevated $\mathrm{NH}_{4}{ }^{+}$concentrations (illustrated here by well 6U) contain elevated $\mathrm{CH}_{4}$ concentrations. Wells with decreasing $\mathrm{NH}_{4}{ }^{+}$concentrations become depleted in $\mathrm{CH}_{4}$ as excess $\mathrm{CO}_{2}$ is consumed as a result of methanogenesis. 

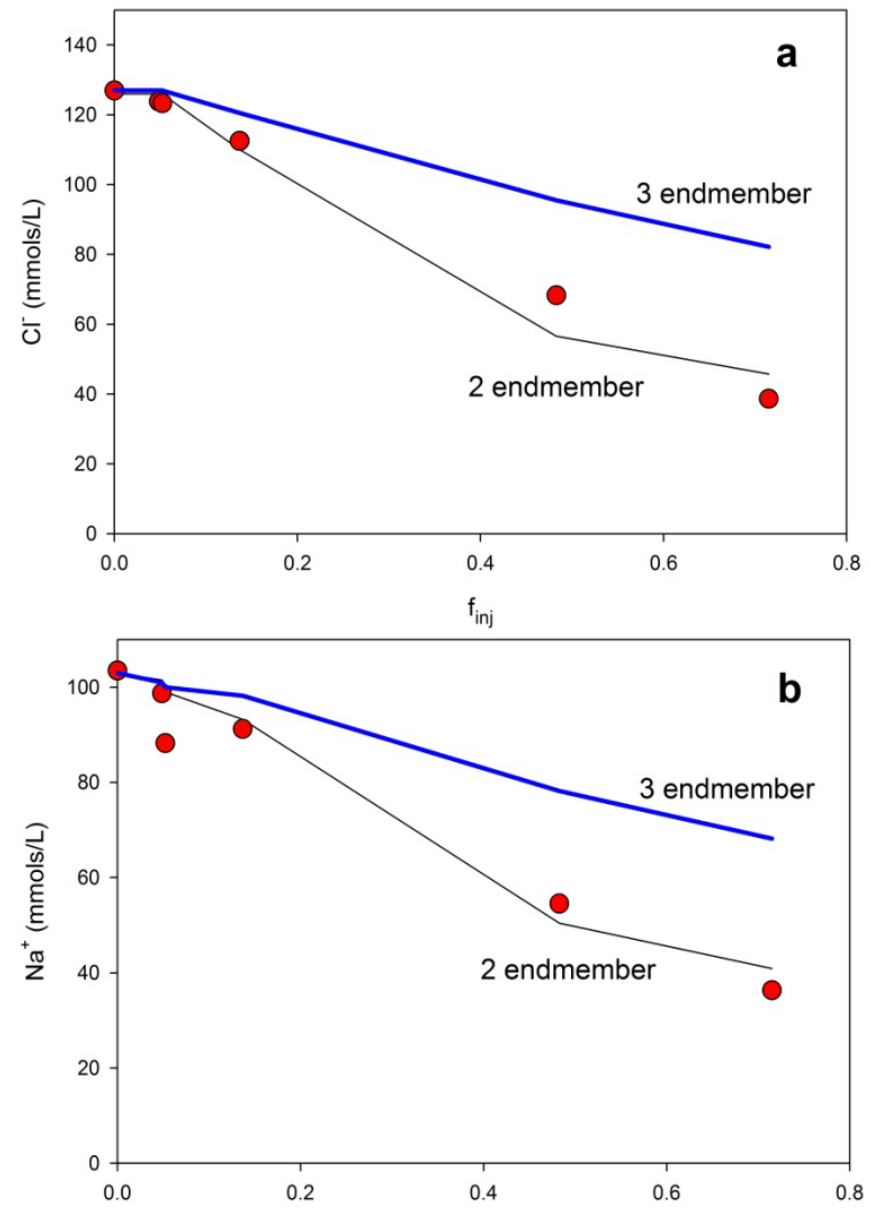

Figure 4.12 Comparison of observed $\mathrm{Ca}^{2+}$ and $\mathrm{Na}^{+}$concentrations (red circles) in the $\mathrm{MC} 1$ to a two endmember solution mixture, (with well $9 \mathrm{U}$ in the $\mathrm{MC1}$ and injectate the two endmembers), and to a three endmember solution mixture (with well 9U, injectate and well $1 \mathrm{~L}$ in the $\mathrm{MC} 2$ as the three endmembers). The two endmember mixture represents injectate migrating upwards to the $\mathrm{MC} 1$ through vertical confinement bypass pathways. The three endmember represents injectate migrating upwards through the MC2 to the MC1. Observed conservative ion concentrations closely match the two endmember solution mixture predicted concentrations. The three endmember solution mixture overpredicts ion concentrations. 

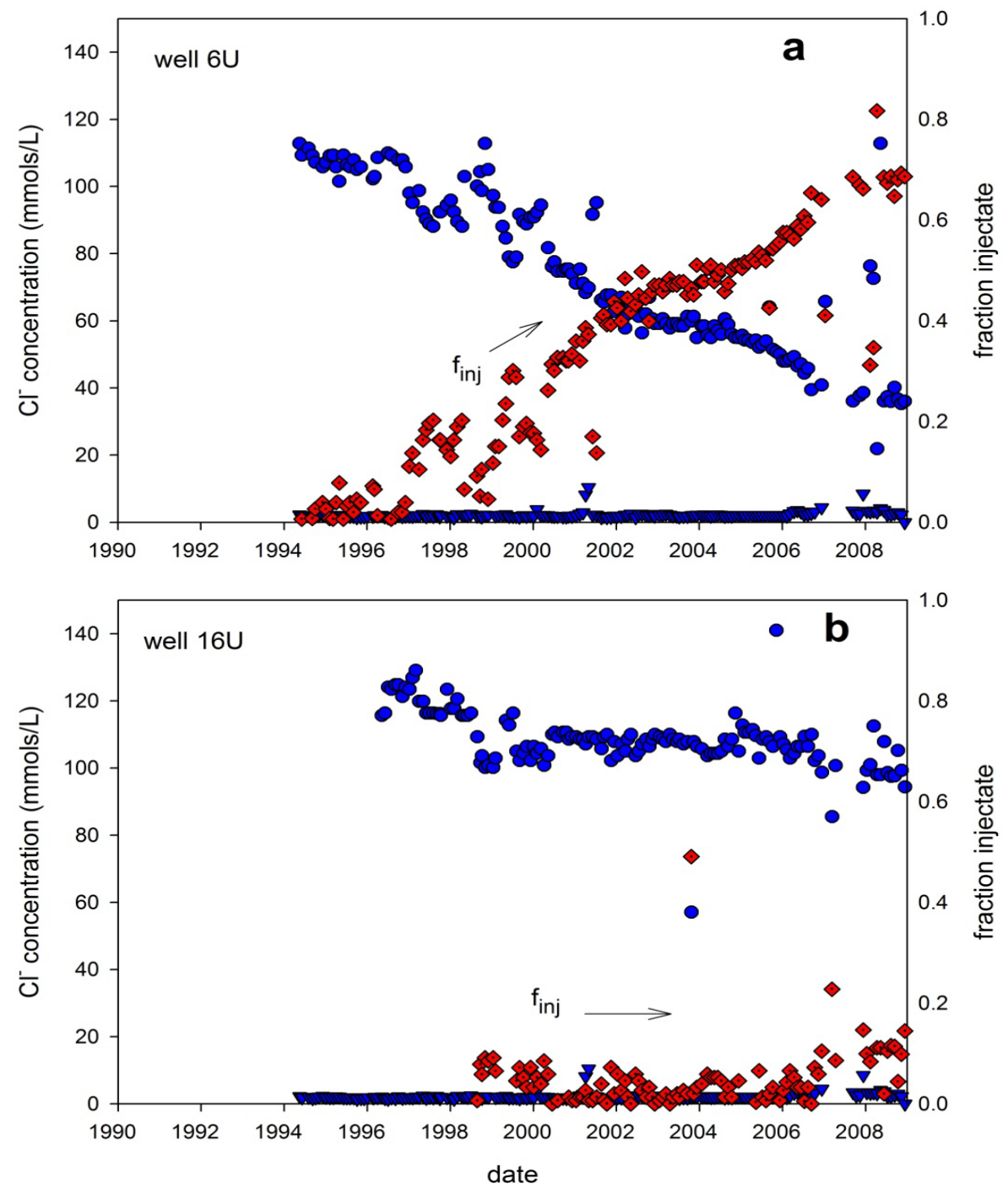

Figure 4.13 Chloride concentrations of injectate (blue triangles) and well $6 \mathrm{U}$ (blue circles graph a), and well $16 \mathrm{U}$ (blue circles graph b) from the MC1 at the SD, and the fraction injectate in each well calculated by the binary mixing model (red diamonds). In graph a, the $\mathrm{f}_{\text {inj }}$ is seen increasing over time as $\mathrm{Cl}^{-}$concentrations decrease over time in well $6 \mathrm{U}$. In graph $b$, the $\mathrm{f}_{\text {inj }}$ for well $16 \mathrm{U}$ appears to remain fairly stable, with a slight increasing trend seen in the post 2006 data. 


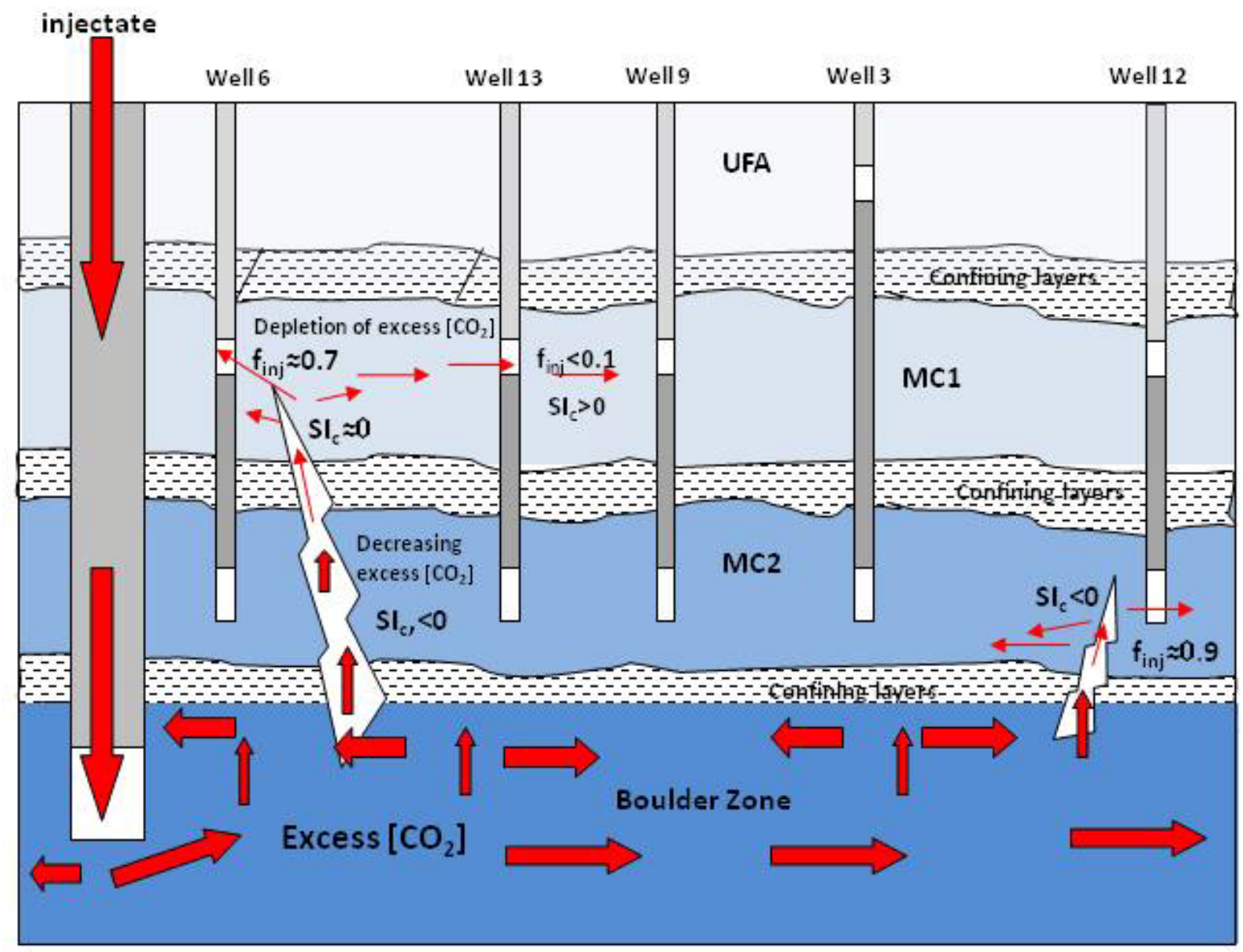


Figure 4.14 Hypothesized injectate flowpaths to the $\mathrm{MC1}$ at the SD. Aquifer layers not to scale, and the APPZ is omitted to simplify figure. Grey on well diagrams is casing, white is open borehole. Injectate (red arrows) is injected into the Boulder Zone, where it migrates upward due to buoyant flow. Vertical confinement bypass pathways allow buoyant injectate to migrate up to the $\mathrm{MC1}$, bypassing underlying confining layers, as illustrated by well 6 . Injectate excess $\mathrm{CO}_{2}$ allows for porosity enhancement over time, while methanogenesis gradually consumes excess $\mathrm{CO}_{2}$ as injectate migrates upwards. Once introduced into the $\mathrm{MC} 1$, injectate flows along horizontal flow paths as it mixes with ambient water, with methanogenesis consuming all excess $\mathrm{CO}_{2}$, resulting in aquifer water becoming oversaturated with respect to $\mathrm{Ca}^{2+}$ (well 13) Well 9 illustrates injectate that has not yet migrated far enough to be detected in the MC1. Well 12 illustrates a vertical confinement bypass pathway to the $\mathrm{MC} 2$, that does not extend up into the $\mathrm{MC} 1$. The shorter migration time to MC2 is evident in the higher $\mathrm{f}_{\mathrm{inj}}$. No evidence of injectate has been detected in the UFA at either the ND or the SD, as illustrated by well 3 . 


\section{CHAPTER 5 SUMMARY AND CONCLUSIONS}

My dissertation used natural chemical and isotopic tracers to determine the source of ammonium $\left(\mathrm{NH}_{4}^{+}\right)$and the migration pathways in the Floridan aquifer system (FAS), south Florida. Water quality of the injectate was chemically and physically distinct from ambient FAS groundwater, and these distinctions were used to determine the presence of injectate and the possible transport pathways to the aquifers overlying the injection zone. The injectate source was treated freshwater, with low salinity, elevated

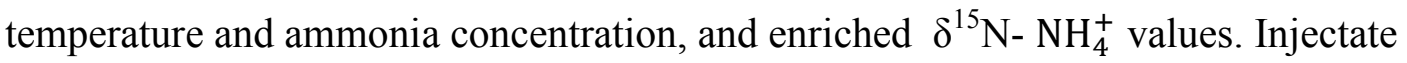
was also determined to be enriched in $\mathrm{CO}_{2}$ and the heavier noble gases, while depleted in lighter dissolved gases, as a result of the cryogenic treatment process at both wastewater treatment plants in this study. These chemical and physical signals were observed to persist in aquifer waters as injectate migrated through various aquifers. Groundwater from the FAS was collected from four hydrogeologic zones at both sites (UFA, MC1, APPZ and MC2). Water chemistry in each of these hydrogeologic zones was chemically distinct from one another, with the UFA brackish water, and the MC1 slightly more brackish. The APPZ represents the transition between the overlying brackish aquifers with the deep saline aquifers. The saline MC2 is close to seawater salinities.

Samples collected from wells with elevated $\mathrm{NH}_{4}^{+}$concentrations showed enriched $\delta^{15} \mathrm{~N}-\mathrm{NH}_{4}^{+}$values, $\mathrm{CO}_{2}$ and heavier noble gas concentrations compared to ambient values and concentrations. The higher heavier noble gas concentrations in these wells could only be possible from injectate, as ambient water has been isolated from the 
atmosphere for thousands of years, and no source would exist in the aquifer matrix. These wells also had elevated tritium levels, which also could only be a result of recharge after the 1950 's, consistent with injectate relative age. The injectate is therefore concluded to be the source of elevated $\mathrm{NH}_{4}^{+}$concentrations found in the $\mathrm{MC} 1$ and the MC2 at the SD, and the APPZ at both sites.

Chloride, $\mathrm{Br}^{-}$, and $\mathrm{NH}_{4}^{+}$binary plots were used to distinguish four injectate plumes at the $\mathrm{SD}$, and conservative ion concentration data suggested that at least three of these plumes were not hydraulically connected. Helium-tritium age dating could distinguish three separate plumes based on relative age, which would be consistent with the findings of the ion binary plots if one of the four plumes was hydraulically connected. Water quality data, stable isotope values, and dissolved gas concentrations for the ND were remarkably homogeneous, and suggest that one plume exists on site.

Two transport mechanisms were identified at the SD: density-driven buoyant vertical flow and slower horizontal advective flow. At the SD, the injectate may first have migrated upwards through vertical pathways from the Boulder Zone to the MC1, bypassing the underlying $\mathrm{MC} 2$, with the freshwater injectate migrating upwards through the saline MC2 as a chemically distinct water body. The four plumes identified at the SD appear to have originated via this confinement bypass pathway. Once introduced in the higher aquifer intervals, the transport mechanism appeared to be horizontal advective flow with mixing of ambient waters. Evidence of confinement bypass pathways were observed in the MC1 and MC2 wells at the South District. Wells thought to lie in the vicinity of these pathways had concentrations of ions, 
isotope values, and dissolved gas concentrations similar to injectate. Binary plots of ions and stable isotopes show mixing trends in the $\mathrm{MC} 1$ back to injectate, with no trends towards the lower MC2. Observed conservative ion concentrations in wells with evidence of injectate migration were consistent with concentrations predicted by the conservative mixing of injectate and ambient $\mathrm{MC} 1$ endmembers, whereas three member mixing ( $\mathrm{MC} 1$, injectate and $\mathrm{MC} 2)$ overestimated ion concentrations.

At the ND the elevated levels of $\mathrm{NH}_{4}^{+}$in the APPZ were originally thought to be the result of a construction incident, where a pulse of injectate water backflowed into an uncased injection well, providing a pathway to the APPZ, and once introduced the plume slowly migrated with the regional flow within the APPZ. Evidence of confinement bypass pathways that were observed at the SD were not observed at the ND. Persistent $\mathrm{NH}_{4}^{+}$concentrations over time however would rule out a one-time pulse origin, as if it were a pulse source, $\mathrm{NH}_{4}^{+}$concentrations would have steadily decreased over time, which they have not. On the basis of the geochemical modeling results, $\mathrm{NH}_{4}^{+}$observed in the APPZ at the ND could be the result of either upward fluid migration through the underlying aquifers, or the result of an offsite confinement bypass pathway.

No evidence of upward migration of injectate was observed in any wells in the UFA at both sites based upon $\mathrm{NH}_{4}^{+}$concentrations, stable isotope, tritium and dissolved gas data. This may be the result of the confinement bypass pathways not extending into the UFA, or may be that wells in the UFA are not located in areas of injectate plume migration, however as elevated $\mathrm{NH}_{4}^{+}$concentrations and the isotopic and dissolved 
gas signatures of injectate have never been detected in the UFA, it may be more likely the result of the former.

Evidence of some type of methanogenesis and $\mathrm{NH}_{4}^{+}$oxidation reactions were observed. Wells with elevated $\mathrm{NH}_{4}^{+}$concentrations had enriched $\delta^{15} \mathrm{~N}-\mathrm{NH}_{4}^{+}$values, more enriched than injectate. Very little $\mathrm{NO}_{2}^{-}$is available for $\mathrm{NH}_{4}^{+}$oxidation, and these very low concentrations may limit the reaction so that only minor amounts of $\mathrm{NH}_{4}^{+}$are lost. Groundwater enriched in $\mathrm{CO}_{2}$ as a result of injectate migration was also observed to have elevated concentrations of $\mathrm{CH}_{4}$. $\mathrm{As}^{\mathrm{CO}_{2}}$ was consumed, $\mathrm{CH}_{4}$ concentrations decreased, until ambient concentrations were reached in wells with low $\mathrm{NH}_{4}^{+}$concentrations.

Injectate water was very undersaturated with respect to the carbonate minerals, as a result of its freshwater source and the enriched $\mathrm{CO}_{2}$ concentrations. Geochemical modeling suggests that porosity enhancement may occur as injectate migrates through the confinement bypass pathways, allowing for greater upward buoyant flow over time, and may provide for dissolution of the aquifer matrix once introduced into overlaying aquifers in the vicinity of the bypass pathways. This would allow for increased injectate flow through the pathways as a result of increased porosity. This was observed in wells thought to be closest to these pathways. Well $6 \mathrm{U}$ for example, had an increasing injectate fraction over the historical period of record.

My dissertation suggests several areas of further research to understand the geochemistry and migration of freshwater injectate into deep aquifers. Further 
microbial studies are recommended, as current federal regulations require high level disinfection (HLD) prior to injection at municipal deep well injection facilities in south Florida as a result of the possibility of survival and migration of pathogens to an USDW. A better understanding of microbial activity under environmental conditions found in the FAS may validate or repudiate the necessity of HLD prior to injection.

Many south Florida utilities are studying the possibility of injecting HLD treated wastewater into the UFA, in order to comply with state regulatory domestic wastewater reuse requirements. The results of this study suggest that the enhanced $\mathrm{CO}_{2}$ concentrations in the proposed treated wastewater water will effect geochemical and biochemical reactions in the aquifer not previously predicted, and may affect future recovery rates of the stored water. Future research is recommended on the effect of enhanced $\mathrm{CO}_{2}$ concentrations on water-rock reactions, and the release of metals such as arsenic into stored water.

Miami Dade Water and Sewer Department currently is working with the US Geological Survey on the acquisition of seismic data to define the subsurface structure of the FAS in the vicinity of the SD and ND. Reflection seismic surveying is being used to test for the presence of fractures, faults, and karst features. The seismic data may be able to locate possible confinement bypass pathways in the vicinity of existing injection sites, and possibly confirm that these structures do not extend into the Upper Floridan Aquifer. Seismic data acquisition is recommended for any future 
injection sites, as it may be able to optimize location of future injection sites in areas where these subsurface features are not found. 
APPENDICES 
Appendix A

Author Guideline for Reference Style 
Chapter 2: Hydrogeology Journal Reference Style

\section{References}

The list of References should only include works that are cited in the text and that have been published or accepted for publication. Personal communications and unpublished works should only be mentioned in the text.

(Give: "name, affiliation, personal communication (or unpublished data), year" in parenthesis.) Do not use footnotes or endnotes as a substitute for a reference list.

\section{Citation in text}

Cite references in the text by name and year in parentheses. Some examples:

- Negotiation research spans many disciplines (Thompson 1990).

- This result was later contradicted (Becker and Seligman 1996).

- This effect has been widely studied (Abbott 1991; Barakat et al. 1995; Kelso and Smith 1998; Medvec et al.

1993).

List style

Reference list entries should be alphabetized by the last names of the first author of each work.

- Journal article

Smith J, Jones M Jr, Houghton L et al (1999) Future of health insurance. N Engl J Med 965:325-329

- Book

South J, Blass B (2001) The future of modern genomics. Blackwell, London

- Book chapter

Brown B, Aaron M (2001) The politics of nature. In: Smith J (ed) The rise of modern genomics, 3rd edn. Wiley,

New York

- $\quad$ Article by DOI (digital object identifier)

Slifka MK, Whitton JL (2000) Clinical implications of dysregulated cytokine production. J Mol Med.

doi:10.1007/s001090000086

- Online document

Doe J (1999) Title of subordinate document. In: The dictionary of substances and their effects. Royal Society of Chemistry. Available via DIALOG. http://www.rsc.org/dose/title of subordinate document. Cited 15 Jan 1999

Always use the standard abbreviation of a journal's name according to the ISSN List of Title Word Abbreviations,see http://www.issn.org/2-22661-LTWA-online.php If the reference title is given in a language other than English, include the English translation in brackets immediately following the title. 
Appendix B

Copyright Release 
SPRINGER LICENSE

TERMS AND CONDITIONS

May 31,2012

This is a License Agreement between Virginia M Walsh ("You") and Springer ("Springer") provided by Copyright Clearance Center ("CCC"). The license consists of your order details, the terms and conditions provided by Springer, and the payment terms and conditions.

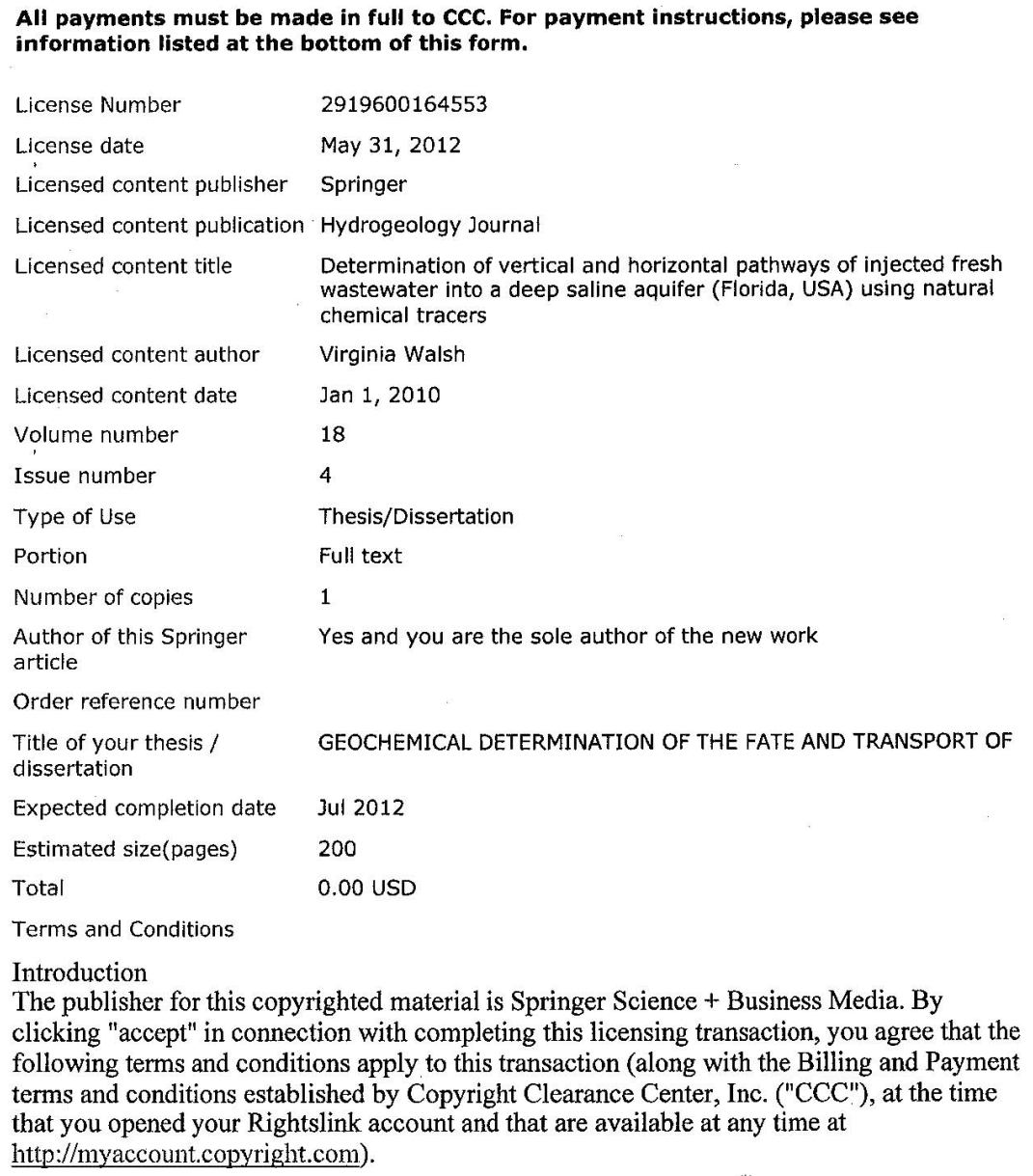
following terms and conditions apply to this transaction (along with the Billing and Payment terms and conditions established by Copyright Clearance Center, Inc. ("CCC"), at the time that you opened your Rightslink account and that are available at any time at http://myaccount.copyright.com).

Limited License 
With reference to your request to reprint in your thesis material on which Springer Science and Business Media control the copyright, permission is granted, free of charge, for the use indicated in your enquiry.

Licenses are for one-time use only with a maximum distribution equal to the number that you identified in the licensing process.

This License includes use in an electronic form, provided its password protected or on the university's intranet or repository, including UMI (according to the definition at the Sherpa website: http://www.sherpa.ac.uk/romeo/). For any other electronic use, please contact Springer at (permissions.dordrecht@)springer.com or permissions.heidelberg@springer.com).

The material can only be used for the purpose of defending your thesis, and with a maximum of 100 extra copies in paper.

Although Springer holds copyright to the material and is entitled to negotiate on rights, this license is only valid, provided permission is also obtained from the (co) author (address is given with the article/chapter) and provided it concerns original material which does not carry references to other sources (if material in question appears with credit to another source, authorization from that source is required as well).

Permission free of charge on this occasion does not prejudice any rights we might have to charge for reproduction of our copyrighted material in the future.

Altering/Modifying Material: Not Permitted

You may not alter or modify the material in any manner. Abbreviations, additions, deletions and/or any other alterations shall be made only with prior written authorization of the author (s) and/or Springer Science + Business Media. (Please contact Springer at (permissions.dordrecht@springer.com or permissions.heidelberg@springer.com)

\section{Reservation of Rights}

Springer Science + Business Media reserves all rights not specifically granted in the combination of (i) the license details provided by you and accepted in the course of this licensing transaction, (ii) these terms and conditions and (iii) CCC's Billing and Payment terms and conditions.

Copyright Notice:Disclaimer

You must include the following copyright and permission notice in connection with any reproduction of the licensed material: "Springer and the original publisher/journal title, volume, year of publication, page, chapter/article title, name(s) of author(s), figure number (s), original copyright notice) is given to the publication in which the material was originally published, by adding; with kind permission from Springer Science and Business Media"

Warranties: None

Example 1: Springer Science + Business Media makes no representations or warranties with respect to the licensed material.

Example 2: Springer Science + Business Media makes no representations or warranties with 
respect to the licensed material and adopts on its own behalf the limitations and disclaimers established by CCC on its behalf in its Billing and Payment terms and conditions for this licensing transaction,

Indemnity

You hereby indemnify and agree to hold harmless Springer Science + Business Media and $\mathrm{CCC}$, and their respective officers, directors, employees and agents, from and against any and all claims arising out of your use of the licensed material other than as specifically authorized pursuant to this license.

No Transfer of License

This license is personal to you and may not be sublicensed, assigned, or transferred by you to any other person without Springer Science + Business Media's written permission.

Nó Amendment Except in Writing

This license may not be amended except in a writing signed by both parties (or, in the case of Springer Science + Business Media, by CCC on Springer Science + Business Media's behalf).

Objection to Contrary Terms

Springer Science + Business Media hereby objects to any terms contained in any purchase order, acknowledgment, check endorsement or other writing prepared by you, which terms are inconsistent with these terms and conditions or CCC's Billing and Payment terms and conditions. These terms and conditions, together with CCC's Billing and Payment terms and conditions (which are incorporated herein), comprise the entire agreement between you and Springer Science + Business Media (and CCC) concerning this licensing transaction. In the event of any conflict between your obligations established by these terms and conditions and those established by CCC's Billing and Payment terms and conditions, these terms and conditions shall control.

Jurisdiction

All disputes that may arise in connection with this present License, or the breach thereof, shall be settled exclusively by arbitration, to be held in The Netherlands, in accordance with Dutch law, and to be conducted under the Rules of the 'Netherlands Arbitrage Instituut' (Netherlands Institute of Arbitration). OR:

All disputes that may arise in connection with this present License, or the breach thereof, shalk be settled exclusively by arbitration, to be held in the Federal Republic of Germany, in accordance with German law.

\section{Other terms and conditions:}

$\mathbf{v 1 . 3}$

If you would like to pay for this license now, please remit this license along with your payment made payable to "COPYRIGHT CLEARANCE CENTER" otherwise you will be
invoiced within 48 hours of the license date. Payment should be in the form of a check invoiced within 48 hours of the license date. Payment should be in the form
or money order referencing your account number and this invoice number RLNK500790498.

Once you receive your invoice for this order, you may pay your invoice by credit card. Please follow instructions provided at that time. 
VITA

VIRGINIA MARY WALSH

$2012 \mathrm{PhD}$ Candidate, Earth Sciences, Florida International University; Florida, USA

2000 MS Geology, Florida Atlantic University; Florida USA

1982 BA Geological Sciences, State University of New York at Buffalo; New York, USA

Publications

Peer-reviewed journal articles

Walsh, V., and R.M. Price. 2010. Determination of vertical and horizontal pathways of injected fresh wastewater into a deep saline aquifer (Florida, USA) using natural chemical tracers. Hydrogeology Journal Vol 18 doi:10.1007/s10040-009-0570-8

Dausman, A.M., Langevin, C.D., Doherty, J., Sukop, M.C., and Walsh, V. (2007) A Unique Approach to Calibrating a Variable-Density Flow and Transport Model. GSA, Vol. 39, No. 6. ISSN 0016-7592.

In Progress

Walsh, V., and Price, R.M. in review. The fate and transport of ammonium from fresh wastewater injected into a deep saline aquifer as determined from natural isotopes and dissolved gases.

Walsh V., and Price, R.M. Effects on carbonate equilibrium from mixing fresh wastewater in a deep saline aquifer, south Florida, U.S.A.

Conference Proceedings:

Hughes, J.D., White, JT., Brakefield-Goswami, L., Walsh, V.M., and Langevin, C.D. 2011. Simulating surface-water management and surfacewater/groundwater interactions in Miami-Dade County, Florida using the SurfaceWater Routing Process for MODFLOW-2005. Submitted to: MODFLOW and More 2011: Integrated Hydrologic Modeling, June 5 - 8, 2011. 1 page.

King, J.N., Foster, A.L., Brakefield, L.K., Walsh V. 2010. Monitoring, modeling, management, and mitigation: potential for densification subsurface disposal, and transport of bouant wastewater treatment plant effluent in Miami-Dade County, Florida, USA. AGU Meeting of the Americas, 8 August 2010. 1 page. 
King, J.N., V. Walsh, K.J. Cunningham, F.S. Evans, C.D. Langevin, A. Dausman. 2009. Analytical models of the transport of deep-well injectate at the North District Wastewater Treatment Plant, Miami-Dade County, Florida, U.S.A.: Eos, Vol. 90, Number 52, 29 December 2009, Fall Meet. Supl., Abstract H21C-0869, 1 page.

Walsh, V. and R. Price. 2008. Geochemical Differentiation of Injected Freshwater Vertical and Horizontal Flow Through Deep Saline Water Karst. American Geophysical Union 2008 Joint Assembly, Ft. Lauderdale, Florida.

Walsh, V., and S. Villamil. 2008. Design of a Monitor Network to Assess Impact to Water Resources as a Result of Public Water Supply Pumpage, MiamiDade County, FL. Florida Water Resources Conference, Tampa Fl.

Walsh V., and Price, R. 2008. Tracing Vertical and Horizontal Migration of Injected Fresh Wastewater into a Deep Saline Aquifer using Natural Chemical Tracers. Conference paper published in the Program and Proceedings of the $20^{\text {th }}$ Salt Water Intrusion Meeting (SWIM 20), Naples, Florida.

Dausman, A.M., Langevin, C.D., Sukop, M.C., and Walsh, V. 2008. Saltwater/Freshwater Interface Movement in Response to Deep-Well Injection in a Coastal Aquifer. Conference paper published in the Program and Proceedings of the $20^{\text {th }}$ Salt Water Intrusion Meeting (SWIM 20), Naples, Florida.

Walsh, V., R.M. Price. 2006. Geochemical Modeling of the Fate and Transport of Injected Fresh Wastewater into a Deep Saline Aquifer. Geological Society of America Annual Meeting, Philadelphia, PA, October 22 - 25, 2006. Abstract Paper No. 179-4 (oral presentation)

Dausman, A., C. Langevin, M. Sukop and V. Walsh. 2006. Development and Calibration of a Variable-Density Numerical Model of a Deep Well Injection Site near the Southeastern Florida Coast. AGU Fall Session, San Francisco, CA.

Walsh, V., R.M. Price, C. Langevin, and A.M. Dausman. 2006. Geochemical Determination of the Fate and Transport of Injected Fresh Waste Water into a Deep Saline Aquifer. National Ground Water Association Ground Water Summit, San Antonio, Texas, April $23-26$ (oral presentation)

Dausman, A.M., C. Langevin, V. Walsh and M.C. Sukop. 2006. Modeling the Potential for Plume Migration from a Deep Well Injection Site. National Ground Water Association Ground Water Summit, San Antonio, Texas, April 23 - 26 